$\because \because \quad \circ$

\% TRAIL THESIS SERIES

IG Ayu Andani

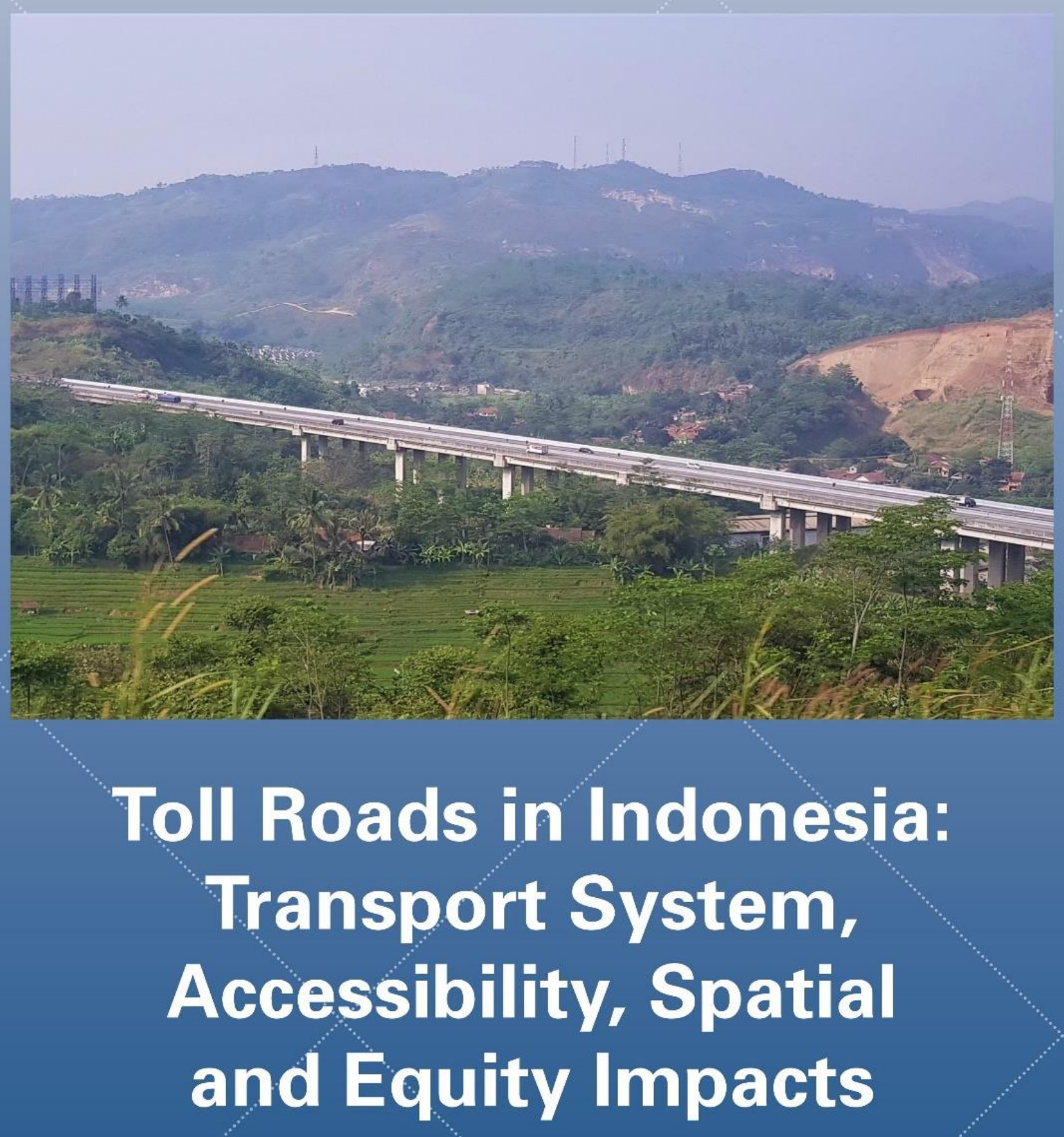




\section{TOLL ROADS IN INDONESIA: TRANSPORT SYSTEM, ACCESSIBILITY, SPATIAL AND EQUITY IMPACTS}

I Gusti Ayu Andani 


\section{Graduation committee:}

prof. dr. ir. G.P.M.R Dewulf

prof. dr. ing. K.T. Geurs

dr. L.C. La Paix Puello

prof. dr. ir. E.C. van Berkum

prof. dr. ir. J. Henseler

prof. dr. Y. Susilo

prof. dr. ir. D. F. Ettema

prof. dr. G.P. van Wee
University of Twente, chairman

University of Twente, promotor

University of Twente, co-promotor

University of Twente

University of Twente

KTH Royal Institute of Technology

Utrecht University

Delft University of Technology

TRAIL Thesis Series no. T2019/8, the Netherlands Research School TRAIL

TRAIL

P.O. Box 5017

2600 GA Delft

The Netherlands

E-mail: info@rsTRAIL.nl

DSI Ph.D Thesis Series No. 19-007

Digital Society Institute

P.O. Box 217

7500 AE Enschede

The Netherlands

ISBN: 978-90-5584-249-0

ISSN: $2589-7721$

This dissertation is the result of a PhD research carried out from 2015 to 2019 at the University of Twente, Faculty of Engineering Technology, Center for Transport Studies. This research is part of the research programme 'The local and regional dimensions in Indonesia's social and economic development', which is funded by The Royal Netherlands Academy of Arts and Sciences (KNAW).

TRAIL Research School for Transport, Infrastructure and Logistics

\section{UNIVERSITY | DIGITAL SOCIETY OF TWENTE. INSTITUTE}

Cover photo: I Gusti Ayu Andani

Copyright (C) 2019 by I Gusti Ayu Andani

All rights reserved. No part of the material protected by this copyright notice may be reproduced or utilized in any form or by any means, electronic or mechanical, including photocopying, recording or by any information storage and retrieval system, without written permission from the author.

Printed in the Netherlands 


\title{
TOLL ROADS IN INDONESIA: TRANSPORT SYSTEM, ACCESSIBILITY, SPATIAL AND EQUITY IMPACTS
}

\author{
DISSERTATION
}

to obtain

the degree of doctor at the University of Twente, on the authority of the rector magnificus, prof.dr. T.T.M. Palstra, on account of the decision of the Doctorate Board, to be publicly defended

on Wednesday the $19^{\text {th }}$ of June 2019 at 16:45 hours

by

\section{Gusti Ayu Andani}

born on the $21^{\text {st }}$ of December 1990

in Denpasar, Bali, Indonesia 
This dissertation is approved by: prof. dr. ing. K. T. Geurs

promotor

dr. L. C. La Paix Puello

co-promotor 


\section{Preface}

This long journey has finally come to an end. I am endowed with a tremendous amount of support and encouragement throughout my $\mathrm{PhD}$ study. It was an incredible journey in which I have learned so many things and have been matured in so many ways. Although I am solely responsible for what has been written in this thesis, completing this thesis has only been possible with the help of numerous people I met and interacted during this journey.

First of all, I would like to express my gratitude to my supervisor and promotor, Prof. Karst Geurs. His high quality standard of academic research has pushed me forward. Without his endless motivation, this thesis might not be completed. I also want to thank him for finding a way for me to stay longer in the Netherlands and, thus, have more time to finish my study. I am further deeply grateful to my daily supervisor, Dr. Lissy La Paix, for a very close and constant supervision. Lissy, you are my role model as a researcher who could accomplish so many things at such a young age. I am very fortunate to have you as my daily supervisor, to whom I could always talk to, even in time I needed a friend.

I would like to thank the members of the graduation committee for their willingness to be part of this committee and allowing me to defend my thesis.

Many people at Institut Teknologi Bandung (ITB) also supported me during my PhD study. I would never be in this position without the help of Dr. Ibnu Syabri and Dr. Shanty Rachmat. I thank both of them for the supervision when I was about to start this project, during the fieldworks and for their contribution in one chapter of this thesis. I would like to thank Dr. Sri Maryati, my master supervisor, who informed me personally about this project when I just finished my master study. I would also like to extend my gratitude to all my colleagues in Regional and City Planning department at Institut Teknologi Bandung, Indonesia, for their full support.

Furthermore, this thesis would never exist without the help of several people in particular during data collections: mbak Retno Wihanesta, my predecessor in this project, who helped me with the data collection and established important contacts, and helped me with some practical stuff when I started this project. Also Husna Tiara, who helped me with a lot of administrative stuff 
and data collection with the local officials during the first fieldwork. My gratitude also goes to Ipsos Indonesia for their help during the household survey: Ika Jatmikasari, Palguno Gijono, Frazna Fadila, Kelik Harjono, and Mia Putri. Thank you for the fruitful discussions, for being responsive to my requests and your willingness to do a last-minute adjustment of the questionnaire.

I would like to thank Angelina Souren, who assisted me with the language editing of this thesis. As an academia herself, she often gave me suggestions to improve the manuscripts and expressed her opinions about this study with another perspective that could help me to understand things better. I also thank her for always giving my work a priority.

It is my pleasure to acknowledge my colleagues in Center of Transport Studies, University of Twente: Bo, Fransesco, Anika, Tiago, Dorette, Tom, Eric, Kostas and others. Also previously: John, Mariska, Sander and Kasper. Thank you for the laugh, gossips, mind-blowing facts and a lot of practical information. I do cherish our serious and crazy time in this group. My special thanks go to my paranimfen: Amelia and Oskar, who are my office mates, who helped me during the preparation of my defence. For Amelia, who is happen to be my housemate as well, thank you for allowing me to stay with you and for being so generous, also thank you for helping me to stay focus with my work amid the domestic drama. And for Oskar, thank you for helping me with the samenvatting and for always be helpful on everything.

Many thanks to my Indonesian fellows in Enschede, who have been very kind, friendly and helpful to me. Among them are: mbak/mas Irena (+Stankev), Dwi Cui, Heksi, Ifha, Habib \& Muthia (+Luqman), Dwi Mandaris \& family, Kamia, Rindia, Miranti \& family, Dhadang \& family, Aji PP, Ari, Andry \& family, Riswan, Lulu, Kunaifi, Yosia, and others (the list is endless!) Thanks also to 'Planolapan cabang NL': Nanda, Riris, Yescha, Atung, Niza, Litha and Nana. Thank you for welcoming me in the Netherland when I first arrived here and for the fun times that we had together. Extra credit goes to Yescha, for helping me with the summary when my mind was stuck and I just found it difficult to translate several words to Indonesian.

I am immensely indebted to my beloved family. First and foremost, my husband and my best friend, Made Juli Nugraha, with whom I have shared many large decisions and small details. This accomplishment would not be possible without his support. I am looking forward to working with him for our other projects $(-)$. This thesis also owes to the love and support of my dear parents: IGM Bawarta and IGAA Kurniadi, my father in law - Nyoman Selamet, my brothers: Andika and Aditya, as well as my sisters-in-law: mbak Distin, Gung Is, and Ratih. Their encouragement has become a constant energy that keeps my spirit alive. Lastly, I would like to dedicate this thesis to my mother-in-law, Ni Ketut Musni, who passed away just a week before I finalized my thesis. It was hard, but she has taught me to have a strong will, perseverance and to finish what I have started. She will always be remembered and missed.

I hope that this work will benefit others, even if it is only a little.

IG Ayu Andani

Enschede, May 2019 


\section{Content}

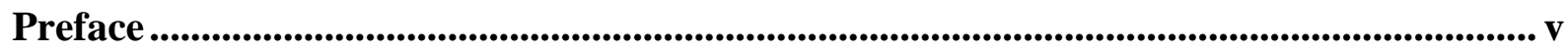

Content .................................................................................................................... vii

1. Introduction ............................................................................................................................. 1

1.1 Background and research motivation ......................................................................... 1

1.2 Research objective and questions.......................................................................... 4

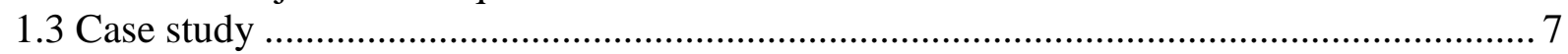

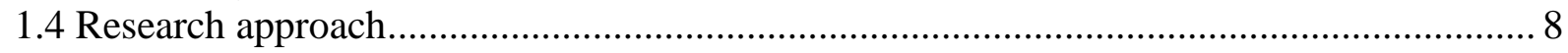

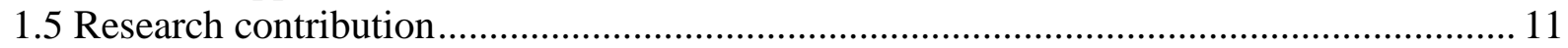

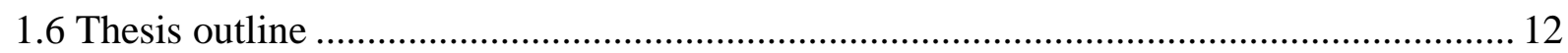

2. Effects of toll road construction on local road projects .................................................. 15

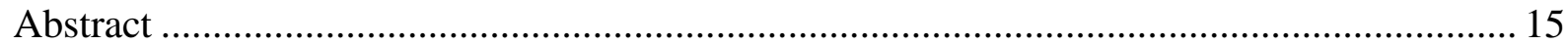

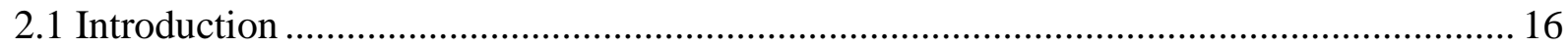

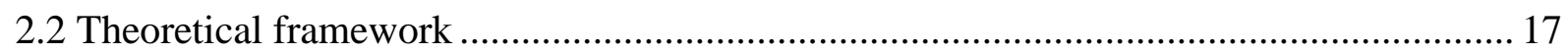

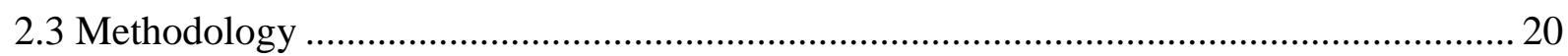

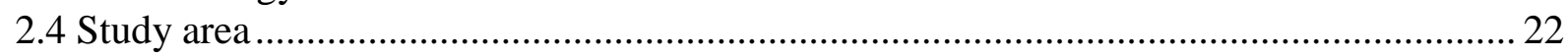

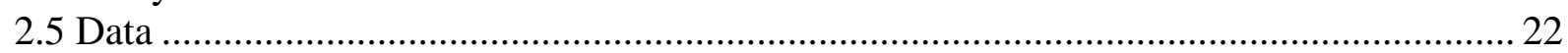

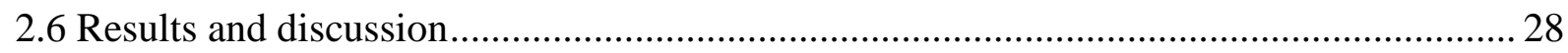

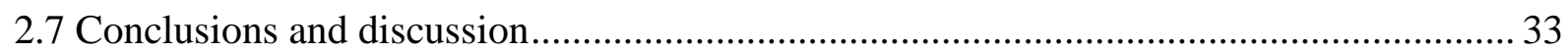

3. Job accessibility and spatial equity impacts ................................................................35

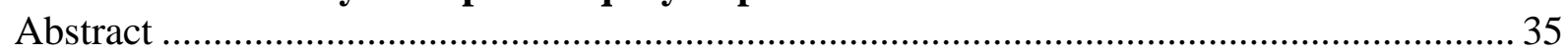

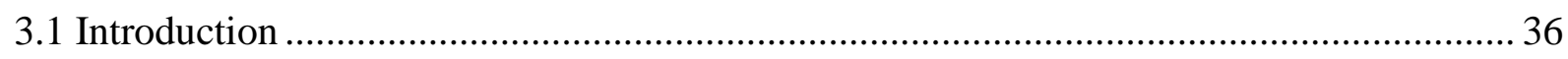

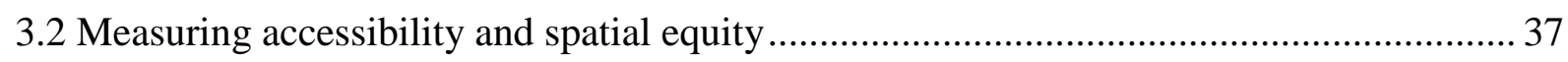

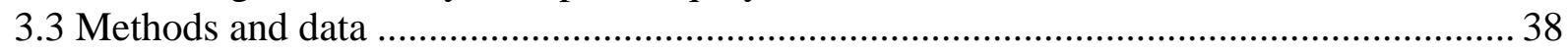


3.4 Study area

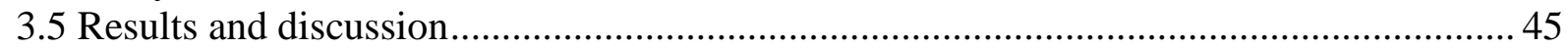

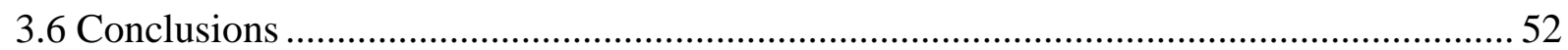

4. Residential location choice.......................................................................................................... 53

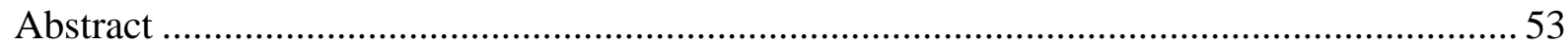

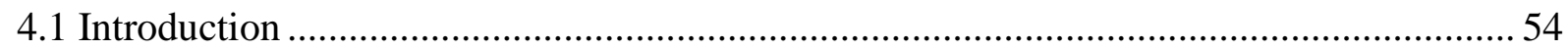

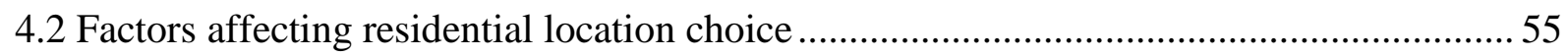

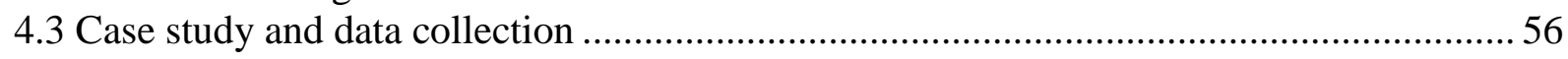

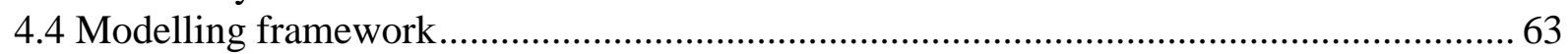

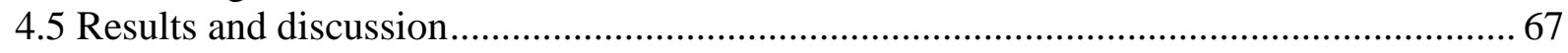

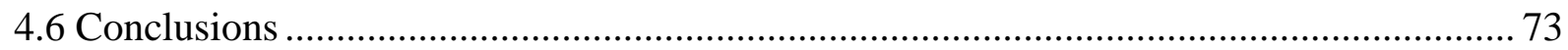

5. Joint estimation of the impacts of toll road on travel behaviour and residential

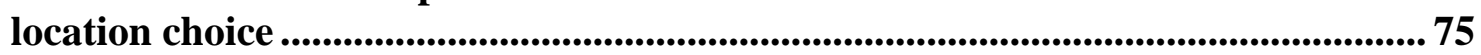

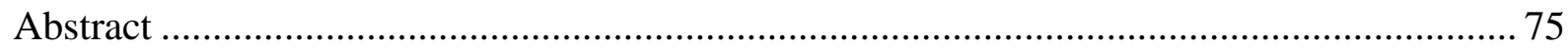

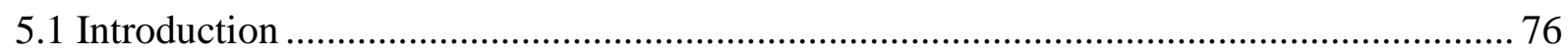

5.2 Travel behaviour and residential relocation due to a toll road construction: literature

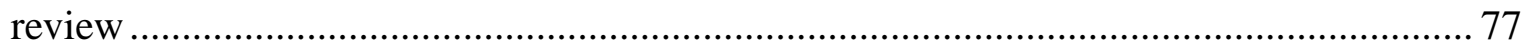

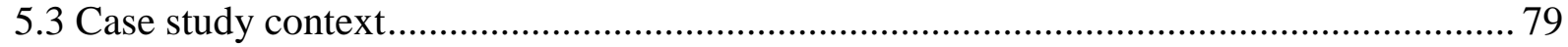

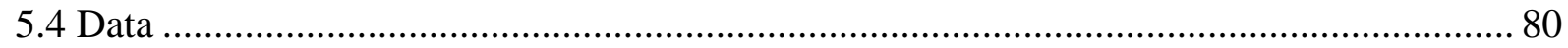

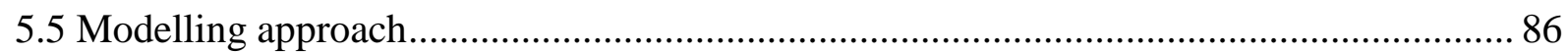

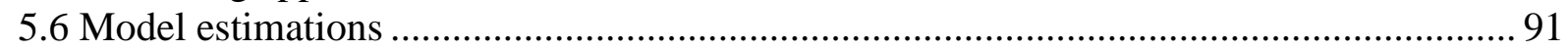

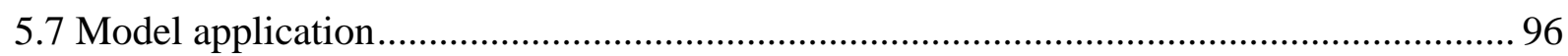

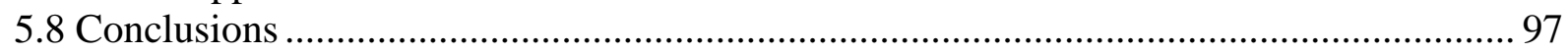

6. Conclusions and recommendations ................................................................................ 99

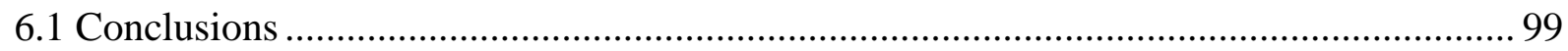

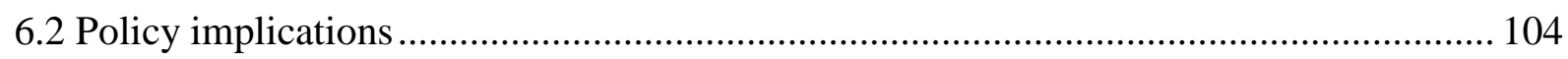

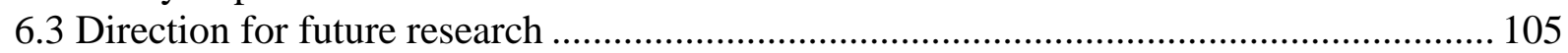

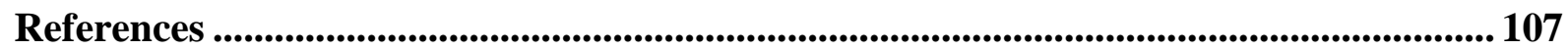

Appendix: Revealed preference questionnaire ..................................................................123

Summary .......................................................................................................................................................... 135

Samenvatting in het Nederlands ................................................................................... 141

Ringkasan dalam Bahasa Indonesia ............................................................................. 147

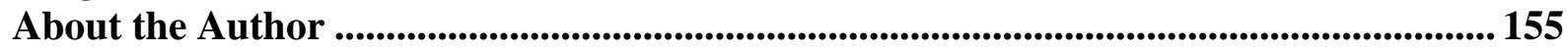

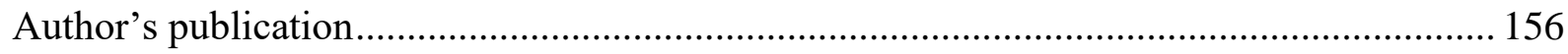

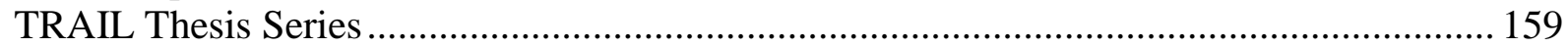




\section{Introduction}

\subsection{Background and research motivation}

Toll roads are built with various objectives. In many developing countries, such as Malaysia, Thailand and Indonesia, a toll is commonly implemented on major highways to help fund their construction (Johansen, 1989). On the other hand, in developed countries and cities like London and Stockholm, a toll can be implemented to influence the users' travel behaviour and reduce congestion (Börjesson, Eliasson, Hugosson, \& Brundell-Freij, 2012; Peirson \& Vickerman, 2008). Regardless of their objective, toll roads can have a variety of effects, both direct and indirect.

Direct effects of major new road construction relate to changes in travel time, travel distance and travel costs. This leads to changes in the users' behaviours. People may, for instance, change their routes or travel modes to explore the new capacity. Indirect effects occur when over time, they may change their job or housing locations (Tillema, 2007). Similarly, firms and their workers may also relocate to areas close to new roads, leading to changes in land use (Chi, 2012; Ghani, Goswami, \& Kerr, 2012; Ji et al., 2014) and induced another road investments (Cervero \& Hansen, 2002). This is considered an indirect effect of the new transport infrastructure. Both direct and indirect effects can be expected to vary across users and regions depending on the current urban structure and on the road users' socio-economic characteristics. This thesis, therefore, focuses on direct and indirect effects of a toll road construction across population groups and regions. This is visualised in Figure 1.1, along with the research presents in this thesis. Solid lines indicate relationships studied in this research, while the dashed lines correspond to relationships that were not able to incorporate owing to data limitations.

In the period 2015 - 2018, almost $600 \mathrm{~km}$ of new toll roads were taken into operation (BPJT, 2018) in Indonesia, as the government pushed the construction of toll roads to improve regional connectivity. The paradigm of 'predict and provide' - that is, the continual construction of transport infrastructure to meet the demand and solve short term traffic problem, such as congestion, without considering both indirect and induced supply effects - is common practice for toll road construction in Indonesia. This thesis looks at induced supply effects and residential location choice, which can be seen as an indirect effect. 


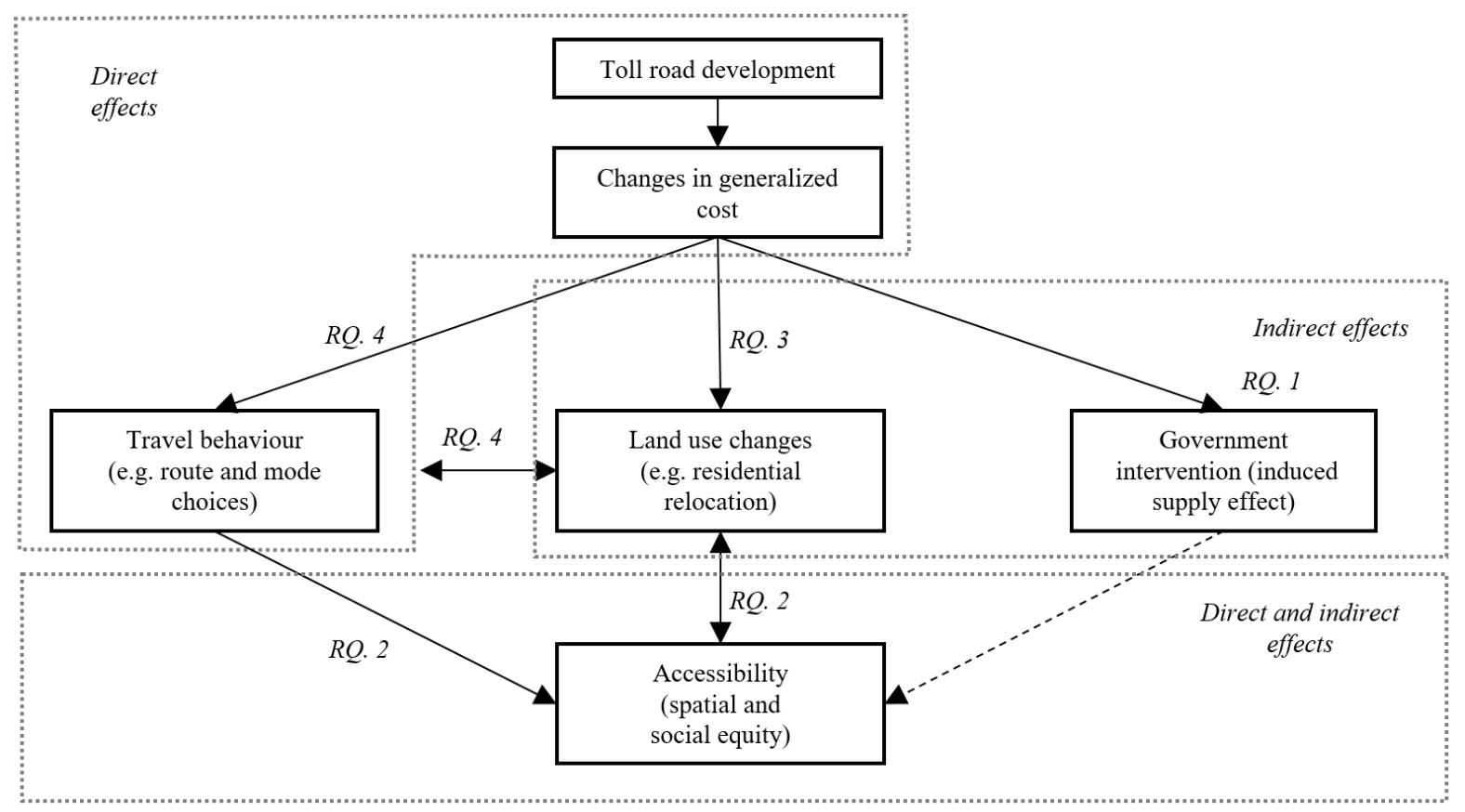

Figure 1.1. Conceptual framework

However, ideally, transport policy should follow the decision-making cycle, in which needs or a rationale are identified first to define the objectives or the desired transport system or system level. Then, an ex-ante evaluation (appraisal) is conducted to identify possible transport policies or projects. Subsequent steps (monitoring, ex-post evaluation and feedback) after the policy has been implemented are often neglected. Ex-post evaluations are essential to assess the achieved outcome and identify direct and indirect effects of road projects, but seldomly conducted. The incorporation of indirect effects in a toll road evaluation produces a reliable forecast for demand to travel via the toll road, as well as the revenues.

New transport investments arguably will induce additional road investments. In the short term, there will be a redistribution of traffic. Some direct effects of major new infrastructure on local road infrastructure occur in support of the construction of the former, meaning that there is a direct connection between the two. For example, a toll road cannot be operated without motorway links that connect the toll road with existing local roads. The construction of a major new road, therefore, has to be supported by the construction of these links and possibly also widening of and other improvements to existing roads, given the expected increase in traffic flow. Furthermore, as the completion of a major road project shortens travel time, it encourages firms and workers to move to the suburbs, looking for lower land price with good accessibility. Therefore, more residential development follows. This urbanisation will further induce travel demand and increase the need for local transport investments.

The literature on induced road investments has focused on major road investments in developed countries (for example, Eliasson, Börjesson, Odeck, \& Welde, 2015; Fridstrom, 1999; Nellthorp \& Mackie, 2000; Nilsson, 1991; Nyborg, 1998; Odeck, 1996, 2010). There is a need for a better understanding of how national road infrastructure projects induce local road projects, and affect the transport and accessibility impacts of the larger investments. It is particularly relevant in developing countries with decentralised government systems such as 
Indonesia, where the different levels of government share the responsibility for the transport networks.

Accessibility, first defined by Hansen (1959) as the potential of opportunities for interaction. There are many definitions afterwards. Among others, Dalvi and Martin (1976) described accessibility as the ease of reaching any activity using the available transport system. Changes in accessibility can influence preferences for residential location and travel (e.g. trip frequency or mode choice (Wegener \& Fürst, 2004). Theoretically, investing in new toll roads will entice individuals to relocate to suburbs, where the land price tends to be lower, leading to changes in land use.

A particular example, Dorodjatoen (2009) investigated how the intensifying relationship between Bandung and Jakarta, two large cities in Indonesia (see Figure 1.2), after the establishment of the Cipularang toll road has affected Purwakarta, a municipality along the toll road where two toll gates are located. He pointed out that the number of large and mediumsized industries has increased by almost $15 \%$ in the area, and suggested that the industrial relocation was due to the proximity to Jakarta and the availability of cheaper labour. The growth of new settlement areas was also observed in Purwakarta. Dorodjatoen found that people from Bandung and Jakarta were the predominant residents of the new settlements. The construction of the Cipularang toll road enabled them to obtain less expensive housing in Purwakarta and commute daily to one of the two big cities.

Furthermore, numerous studies have explored the factors that affect residential location choice. Important determinants that influence housing choices include the characteristics of dwelling and neighbourhood, accessibility, socio-demographic characteristics, as well as an individual's lifestyle or preferences (latent factors) (Choudhury \& Ayaz, 2015; Olaru, Smith, \& Taplin, 2011; Tillema, van Wee, \& Ettema, 2010). Travel preferences may also influence residential location decision. This is referred to 'self-selection' where people select themselves into neighbourhood that reflects their travel attitudes (Cao, Xu, \& Fan, 2010; van Wee, 2009). On the opposite, characteristics of the built environment in residential areas can also affect individuals' daily travel behavior. For instance, Handy, Cao, and Mokhtarian (2005) observed significant changes in travel mode and car travel distances after housing relocation. Therefore, residential location choice and travel behaviour are often modelled simultaneously to identify self-selection process.

Moreover, a new road can have diverse equity impacts, ranging from people's social opportunities to access regional economic developments. Toll road, in particular, allows users a trade-off between a quicker but expensive route and a slower but inexpensive route. In contrast with the classical view that infrastructure construction will improve accessibility and promote equity across regions and individuals, the additional costs and changes in travel time due to the establishment of a toll road can be unevenly distributed across a population and regions. There can even be groups for which the new road has detrimental effects. For example, van Dijk, Krygsman, and de Jong (2015) showed that high-income commuters are more likely to benefit from toll roads whereas lower-income commuters tend to choose alternative non-tolled routes. The transport system, arguably, should be able to provide access to opportunities, such as jobs, as inequity in access is related to income inequity and also lower human capital (Mejía \& StPierre, 2008). However, in practice, equity appraisals receive little attention in transport project evaluations. 
Current transport project evaluations are mostly based on economic evaluations (e.g. cost and benefit analysis), rooted in utilitarian theory (Di Ciommo \& Shiftan, 2017). It assumes that a project has net positive welfare effects if the benefits are large enough so that the gains for the wealthy people who benefit from the project (the winners) compensate for the effects on the poor who cannot afford any extra costs or are unable to use the current transport service (the losers), also known as the Hicks-Kaldor principle (Hicks, 1939; Kaldor, 1939). However, as pointed out by van Wee (2012), the implementation of this hypothetical compensation can easily lead to a wide range of problems involving high transaction costs and asymmetric information. Moreover, there is no particular concern for how the benefits are distributed among individuals (Pereira, Schwanen, \& Banister, 2016).

This has resulted in transport systems that do not provide all individuals with access to new opportunities or activities in the area, thus carrying the risk that certain groups become socially excluded. A more integrated land use and transport planning is needed to enhance the intended effects and limit inequality caused by road projects. This thesis presents a more comprehensive method for including social appraisals in ex-post evaluation of major road investments.

This research was funded by The Royal Netherlands Academy of Arts and Sciences (KNAW), as part of the Scientific Programme Indonesia-Netherlands (SPIN); within the joint research project The local and regional dimensions in Indonesia's social and economic development.

The rest of this chapter formulates the research problem and objective, explains the research approach, and points out its relevance from a scientific point of view in order to make the reader familiar with the context and the objective of this research.

\subsection{Research objective and questions}

The main objective of this study is as follows:

To provide a comprehensive understanding of the direct and indirect impacts of toll roads in the Jakarta - Bandung region in Indonesia, and how these impacts differ between geographical regions and population groups.

In order to address this research objective, several research questions were identified. Figure 1.1 shows the conceptual framework of this study and the connection of each research question to provide empirical evidence for the impacts of a new toll road, both direct and indirect. This thesis comprises four parts, each which addresses a specific research question.

\section{To what extent does the construction of national toll road projects induce local road projects in Indonesia?}

It is well known from the literature that the construction of new major roads or expansion of existing road capacity may induce extra travel demand and new road investments, as many drivers will like to adjust their route to explore the new capacity. A study of state highway expansions in the United States revealed significant induced demand and induced investment effects (Cervero \& Hansen, 2002). The researchers argued that the road investments not only stimulated travel demand, but also responded to it by adding more capacity on existing roads to cope with the increasing travel demand and congestion.

Several studies have examined road investment decision-making at the national level. However, to my knowledge, no study has linked national road investments to decision-making for local road investments, even though local roads are required to link new urban development with 
major roads and thereby improve regional accessibility. It is particularly relevant in countries with decentralised government systems such as Indonesia, where the different levels of government share the responsibility for the transport networks.

Indonesia's central government authorises investments in national roads, e.g. toll roads, while the lower-tier levels of government control local road projects. Local roads connect districts and communities, carry low traffic volumes and have the lowest speed limit. Among other things, decentralisation aims to increase local government responsiveness and improve infrastructure services at the local level. Coordination, however, has become a major concern to increase the benefits of transport investment across regions. There is no existing academic research yet on accessibility and government transport infrastructure investment in the Indonesian context.

This part of the thesis examines the extent to which the construction of national toll roads induces local road investments in the Jakarta - Bandung region in Indonesia, taking urban development and local decision-making into account. The remainder of this thesis focuses on the Cipularang toll road as a case study.

\section{What is the impact of the Cipularang toll road on job accessibility and spatial equity in the Jakarta - Bandung region?}

Equity is often considered a part of major transport infrastructure investment appraisal. Accessibility indicators are often used for equity analysis because of their emphasis on people and their interactions with places, and also because they capture both transportation infrastructure and the spatial structure of the destinations (land use) (Grengs, 2012; Geurs and Van Wee, 2004).

Several ex-post evaluations have been conducted on the accessibility impacts of motorway developments in Europe for periods of twenty years and longer. For instance Holl (2007) and Axhausen, Froelich, and Tschopp (2011) found that with motorway construction, the accessibility gains shift the focus away from central cities to peripheral areas. However, in fact, a new road can have diverse equity impacts, ranging from people's social opportunities to access regional economic developments. Ideally, new transport investment should be able to improve people's access to goods, services and opportunities (Lucas, 2012). Similarly, Grengs (2010) argued that one of the most critical tasks of any transportation system is to provide access for workers to jobs.

This part presents an ex-post evaluation of the impact of a toll road on job accessibility and spatial equity in a developing country context, which to my knowledge has not been done before. So far, the few studies of the impacts of toll roads described in the literature have been ex-ante studies, such as by van Dijk et al. (2015), who conducted a GIS-based evaluation of traffic and job accessibility impacts of planned toll roads in Cape Town, South Africa.

Job accessibility has been found to increase in the areas close to the new infrastructure, also for low-income workers in several studies (e.g. in Fan, Guthrie, \& Levinson, 2010). However, job access involves employers and workers; competition may exist between employers or between workers, depending on which resources are becoming scarce and where. Spatially, such competition will be projected onto the land use system - locations of workers' residence and workplaces - and is called location-based competition (Cheng \& Bertolini, 2013). In this thesis, 
the competition effect was incorporated into the equity assessment in job accessibility across the Jakarta and Bandung area.

\section{What is the impact of the Cipularang toll road on residential location choice?}

Many studies have found evidence of urban growth along road corridors or around motorway exits (see, for example, Aljoufie, Zuidgeest, Brussel, \& van Maarseveen, 2013; Chi, 2010; Ji et al., 2014; Müller, Steinmeier, \& Küchler, 2010). Spatial developments can be explained by the behaviours of individuals and firms. Changes in accessibility that result from the interaction of land use and new transportation infrastructures can influence preferences for residential location (Wegener \& Fürst, 2004). Several studies have found a relationship between housing choices and accessibility indicators, for example, travel time to work (Kim, Pagliara, \& Preston, 2005; Vega \& Reynolds-Feighan, 2009), (monetary) cost of travel to work (Olaru et al., 2011; Tillema et al., 2010), and accessibility of various urban facilities (Chen, Chen, \& Timmermans, 2008; Haugen, Holm, Strömgren, Vilhelmson, \& Westin, 2012; Kortum, Paleti, Bhat, \& Pendyala, 2012).

Studies into residential relocation in response to a toll road or motorway construction in developing countries are also limited in the literature, although several studies have found significant deviations from developed countries. For instance, residential relocation decisions in developing countries are often strongly influenced by affordability (Kumarage, 2005; Sharma \& Chandrasekhar, 2014) or social networks (Limbumba, 2010). In developing countries, the maximum amount of travel time that people are willing to allocate is also greater than in developed countries (Banerjee, Ye, \& Pendyala, 2007), and the same applies with regard to travel budget (Bocarejo \& Oviedo, 2012). This, of course, can also affect the selection of the housing location.

Moreover, residential location choice is a complex decision-making process. Important factors that influence housing choices include the characteristics of dwelling and neighbourhood, socio-demographic characteristics, as well as an individual's lifestyle or preferences (which are latent factors). Research has also revealed a significant interdependence between these factors. For instance, large households or households with children prefer larger homes, close to school areas and in safer environments (Hipp, 2010; Ozturk \& Irwin, 2001), or close to friends or relatives (Kan, 2007; Mulder \& Cooke, 2009) so they can also help with the children. Therefore, they tend to live in suburban or less compact neighbourhoods (Walker \& Li, 2007). Lowincome households, on the other hand, prefer to live close to their places of work to save on transport costs, and close to urban facilities because they prefer to walk or take public transport to them instead of go by car. The result of that is low-income households are concentrated in high-density (compact) neighbourhoods (Liao, Farber, \& Ewing, 2015).

In addition, residential satisfaction acts to express the effects of socio-economic and neighbourhood characteristics on residential relocation (Speare, 1974). This consider as a factor that push people to move (Clark \& Onaka, 1983). This part of the thesis examines residential location choice in connection to toll road presence by also controlling observed factors, such as socio-economics, travel characteristics, housing characteristics, and unobserved factors, which are satisfaction components. 
4. How do variations in Level of Service (LoS) of the Cipularang toll road and socio-economic attributes simultaneously affect residential location, route and mode choices across population segments?

Toll roads allow users a trade-off between a quicker but expensive route and a slower but inexpensive route. This has been shown to affect the users' behaviour, i.e. they may change route, mode, trip frequency or departure time (Nielsen, 2004; Vrtic, Schuessler, Erath, \& Axhausen, 2010). However, the effects depend on the users' socio-economic backgrounds and on trip characteristics. For instance, Nielsen (2004) and Vrtic et al. (2010) found that participants with non-commuting trips were unlikely to change their trips since this kind of trip is often a spontaneous and instant ("urgent") trip that cannot be altered. Some commuters would adjust their daily trips, i.e. change route or departure time, to avoid the toll. The congestion charge in Stockholm was found to affect high-income groups and residents in central parts of the city where a congestion charge was implemented the most as these individuals drive more (Eliasson \& Mattsson, 2006). Di Ciommo and Lucas (2014) found that road-pricing in Madrid would mostly affects unskilled and lower-income individuals; low-income drivers try to reduce their use of tolled roads and have to find new arrangements for these trips, i.e. switch to public transport, spend double the time travelling or stay at home. Similarly, van Dijk et al. (2015) examined a planned toll road in Cape Town, South Africa, and also found that lower-income people prefer non-tolled routes.

In contrast with other studies in developed countries, Ardiyono, Parenrengi, and Faturachman (2018) found that toll road construction in Indonesia attracts a higher number of trips and that people tend to divert to the new toll road (Prahara, Suangga, \& Ansori, 2018). However, these studies did not distinguish the effects of the toll road across population groups while, for example, low-income individuals are unlikely to travel via the toll road often and are quite sensitive to changes in travel cost. This part of the thesis, therefore, looks at travel behaviour effects across population groups due to the new toll road in greater detail.

Previous studies have shown a connection between travel behaviour and residential location. For instance, Handy et al. (2005) observed significant changes in travel mode and car travel distance after residential relocation. On the other hand, people can also choose their residential location based on their travel preferences. This association is referred to residential 'selfselection', meaning that people select themselves into a particular neighbourhood to enable them to travel with their preferred travel mode (Cao et al., 2010; van Wee, 2009). Ignoring selfselection can lead to 'false' causal effects of neighbourhood aspects on travel behaviour in research results (Bhat \& Guo, 2007). Therefore, self-selection is taken into account in the present study through a joint estimation of the effects of travel, socio-economic, housing and neighbourhood characteristics on residential location, route and mode choices.

\subsection{Case study}

The research described in this thesis used the Jakarta - Bandung region in Indonesia (Figure 1.2) as case study, with the Cipularang toll road connecting the two big cities. This toll road, opened in 2005, connects Cikampek (a district in Karawang) via Purwakarta to Padalarang (a district in the Bandung municipality), thus it was named the Cipularang (Cikampek Purwakarta - Padalarang) toll road. The project was proposed as a solution to solve the traffic problems along the Bogor and Purwakarta areas, which were the main routes between Jakarta and Bandung. The toll road shortens the travel time between Jakarta and Bandung by more than half, from around five hours to two hours. The distance is about $180 \mathrm{~km}$ and the modal split is dominated by cars (Lubis, Armijaya, \& Dharmowijoyo, 2005). Note that toll roads are very 
different from local roads or untolled motorways, as transport in Indonesia is dominated by motorcycles.

With the presence of the Cipulang toll road and the development of many new towns, industrial estates and local road developments in the corridor in between, the two areas now physically integrated, forming the largest urban population in Indonesia (Firman, 2009). Even though the Jakarta - Bandung region takes up less than $1 \%$ of the country's surface area, it is highly important at the national scale. It contains $30 \%$ of the total length of the nation's major toll roads and $14.4 \%$ of the total population, namely 36,203,835 people according to 2013 data (BPS, 2017). The area also contributes around $20 \%$ of the national gross domestic product (GDP).

A few earlier studies (e.g. Dorodjatoen, 2009; Firman, 2009) examined on the area around the toll roads in the Jakarta - Bandung region. The present study looks at a wider area, to be able to capture impacts on the routes taken before the toll road was constructed as well. Specifically, this research also looks at the western part of the area as it too may be affected by the Cipularang toll road.

\subsection{Research approach}

To be able to investigate how the establishment of the Cipularang toll road affects the transport system and how its benefits are distributed across various population segments and regions, the analysis described in this thesis considers both the regional and the individual level. The analysis of the regional impact (research questions Nos. 1 and 2) was carried out by GIS spatial analysis and modelling.

Furthermore, an analysis at the level of individuals was carried out to answer research questions Nos. 3 and 4. Stated and revealed preference data were collected for residential location, route and mode choices, from a household survey among 1,600 respondents who live in the proximity of the Cipularang toll road, using computer-aided personal interview (CAPI) technology. Respondents were selected from areas that experienced major land use changes, covering 35 villages (sub-districts). Ten sub-districts located between 6 and $12 \mathrm{~km}$ from the toll road were also included in the sample as control. Furthermore, the respondents were sampled on the basis of stratified random sampling. Grouping was based on the proportion of gender and age groups in the population.

The research approach to answering each research question is discussed below.

1. To what extent does the construction of national toll road projects induce local road projects in Indonesia?

This question is addressed in Chapter 2. It focuses on aspects of the decision-making process for transport infrastructure investments in a decentralised governance setting. The analysis was carried out in two steps, namely:

a. Analysis of the process of decision-making and factors that influence transport infrastructure investment in both central and local government. Semi-structured interviews with local officials in the Jakarta - Bandung area were conducted to obtain data on the decision-making process. To support these data, legal documents related to public infrastructure investments were also collected and analysed. 
b. Modelling of direct and indirect relationships between toll road construction and local road projects. Four binary logit models were formulated using data for local road projects, characteristics of toll roads in the region and land use. The first model is the base model, which attempts to describe the decision-making for local road projects. The second model is the direct effect model, in which toll road construction is assumed to affect local road projects directly. The third model is the indirect effect model, which assumes that urban development triggers the construction of local roads. Finally, the fourth model is the composite model, which combines the base, direct and indirect effect models.

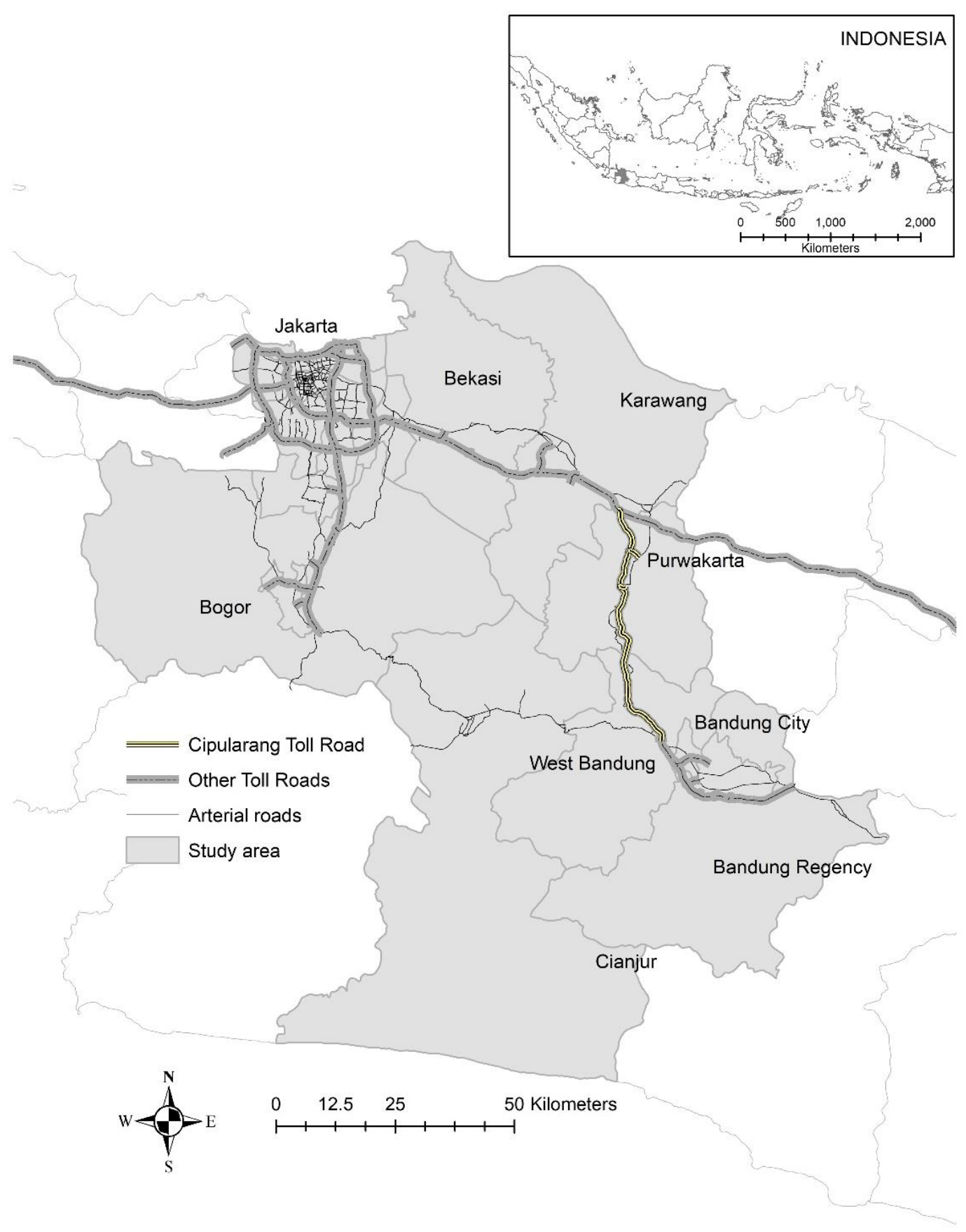

Figure 1.2. Study area 
2. What is the impact of the Cipularang toll road on job accessibility and spatial equity in the Jakarta - Bandung region?

This research question is answered in Chapter 3. To assess the impact of the Cipularang toll road on job accessibility and spatial equity, scenarios with and without the toll road were applied with the following three stages of analysis:

a. A macroscopic traffic simulation model was developed using the 4-step transport model extension Traffic Analyst for ArcGIS (Rapidis, 2018). It was calibrated to produce traffic flows, travel time and generalised cost matrices and used in a scenario with and without the toll road. Congestion effects were taken into account in the traffic model through the addition of capacity restraints of the road network.

b. Several accessibility indicators were calculated by using the generated travel time and cost matrices, taking into account the number of jobs and the size of the working population. Job competition, represented by the Shen index, was also measured to reflect the distributions of employment and working population.

c. Spatial equity analysis is conducted on the basis of two equity indices: the Palma ratio and the Gini coefficient. Next, a two-step cluster method was performed to identify the characteristics of districts that are likely to benefit from the new toll road and classify them based on the accessibility impacts.

\section{What is the impact of the Cipularang toll road on residential location choice?}

This research question is addressed in Chapter 4. In order to examine the impact of the toll road presence on residential location choice, a discrete choice model framework was used since the data collected were the result of a stated choice experiment. The assumption of this model is that each individual in the survey will choose an alternative that has the highest utility. The analysis comprises the application of traditional mixed logit and hybrid choice model, to model the effects of socio-economics, travel characteristics, housing characteristics on residential location choice simultaneously, with the latentvariable models capturing satisfaction with current neighbourhood and housing.

In the stated choice experiment, the respondents were provided with several choice cards. For each choice card, they had to choose between hypothetical house A, house B and their current home. Each option had a different value of attributes (rent/land tax, travel time to work, travel cost to work and distance to toll gate). The values of the attributes were pivoted from the respondents' current data, to capture a similar context as the actual behaviour.

Furthermore, psychometric indicators are used as measurement of the latent variables. The indicators are based on the satisfaction with the current housing and neighbourhood. It includes, for instance, the satisfaction of accessibility aspects, such as transport network condition and distance to work and urban facilities. Indicators related to housing and neighbourhood are affordability house size, which is also cover garage and garden, number of bedrooms, building health and safety standard, exposure to traffic emissions, neighbourhood safety and the aesthetics of the neighbourhood. 
In addition, the influence of the distance to toll road on residential location choice was assessed by simulating four buffer areas based on distance to the toll gates: less than 2 $\mathrm{km}$, between 2 and $5 \mathrm{~km}$, between 5 and $10 \mathrm{~km}$ and more than $10 \mathrm{~km}$, using the same variables as the hybrid choice model.

4. How do variations in Level of Service $(L o S)$ of the Cipularang toll road and socioeconomic attributes simultaneously affect residential location, route and mode choices across population segments?

Chapter 5 deals with this fourth research question. The toll road has given the users the opportunity to make a trade-off between higher travel costs and faster travel. To assess to what extent the changes in travel cost and travel time accomplished by toll road usage affect route and mode choices, a stated choice experiment was conducted, as no data was available to examine the toll road impacts on the route choice. Three logit models were developed to investigate the effect of toll road usage, residential location and socioeconomic characteristics on route and mode choices.

A traditional mixed logit model was first estimated by incorporating the stated and revealed preference data. Error components with panel effects were also estimated to account for unobserved heterogeneity. This model was further improved by the addition of latent variables, namely attitudes regarding the toll road and used travel mode for trips via the toll road. Attitudes explain part of the random component of the utility function through individual-specific unobserved attributes.

Furthermore, to test self-selection, a joint model discrete choice model was developed to estimate route, mode and residential location choice simultaneously. This model reflects a sequential structure on multiple decisions. As described by Bhat and Guo (2007), selfselection can be accounted for through the effect of unobserved heterogeneity in both travel behaviour and residential location choice.

\subsection{Research contribution}

To date, to the author's knowledge, there have been no ex-post evaluations of major transport infrastructure in Indonesia. There is no published academic research on this topic and a decade after the Cipularang toll road began operating, its impact on the region was still unexamined. Given the huge impact of the toll road on the transport system, this is somewhat surprising. This research is innovative at scientific level on each part of this research:

1. The contribution of Chapter 2 is the use of high temporal and spatial resolution to analyse ex-post toll road constructions on local road projects in developing countries, as well as combining statistical analysis, with spatially detailed data to perform a robust predictive model.

2. Chapter 3 adds to the literature by examining job accessibility and spatial equity impacts of a major toll road in a developing country context. Congestion effects were estimated using Traffic Analyst, an ArcGIS plug-in. Value of time estimates were derived from a stated choice experiment which was part of a large scale survey conducted as part of this thesis. 
3. Chapter 4 presents a comprehensive ex-post evaluation of toll road construction on residential location choice in the context of developing countries, using revealed and stated preference survey. Few quantitative studies are available on the impact of road infrastructure on residential location choice in developing countries, and to the author's knowledge, no studies have addressed toll roads. Toll roads add complexity as explicit trade-offs between travel time savings and toll fee costs are introduced. Existing studies in Indonesia (e.g. by Nurlaela \& Curtis, 2012) did not involve any mathematical modelling or a representative sample of the population.

4. Chapter 5 contributes to a better understanding on the impact of a toll road construction on short-term travel and long term residential location choices of individuals. It applies a traditional mixed logit and a hybrid choice model to incorporate unobserved factors to investigate residential location, route and mode choices, combined with an assessment of the interaction of direct and indirect effects of the toll road through the use of a joint estimation between residential location, route and mode choices. This joint model provides a complete portrait of the spatial patterns of travel changes in response to the toll road construction.

In terms of policy relevance, the outcome of this study provides an ex-post evaluation framework that can help improve ex-ante evaluations of transport infrastructure projects by incorporating travel behaviour, accessibility and equity impacts.

\subsection{Thesis outline}

The subsequent chapters in this thesis present the research at the regional and individual levels. Figure 1.3 presents the connection between each chapter and the impacts discussed in section 1.1. The remainder of this thesis is organised as follows:

Chapter 2 looks at the extent to which the construction of national toll roads in the Jakarta Bandung region in Indonesia induces the development of local road projects in the vicinity of the toll road.

Chapter 3 examines the impact of the Cipularang toll road on job accessibility and spatial equity by isolating the effect of the toll road.

In contrast to Chapters 2 and 3, Chapters 4 and 5 focus on the toll road's impacts on individuals. Chapter 4 addresses the influence of the Cipularang toll road, along with socio-economics, travel characteristics, housing characteristics and latent variables on residential location choice.

Chapter 5 provides some insight into how changes in Level of Service (LoS) of the Cipularang toll road and socio-economic attributes simultaneously affect residential location, route and mode choices across population segments. This chapter also investigates the association between location choice and route and mode choice.

Chapter 6, finally, provides a summary of the research, alongside the conclusions, augmented with policy recommendations and suggestions for future research. 
Toll road development impacts

Regional level

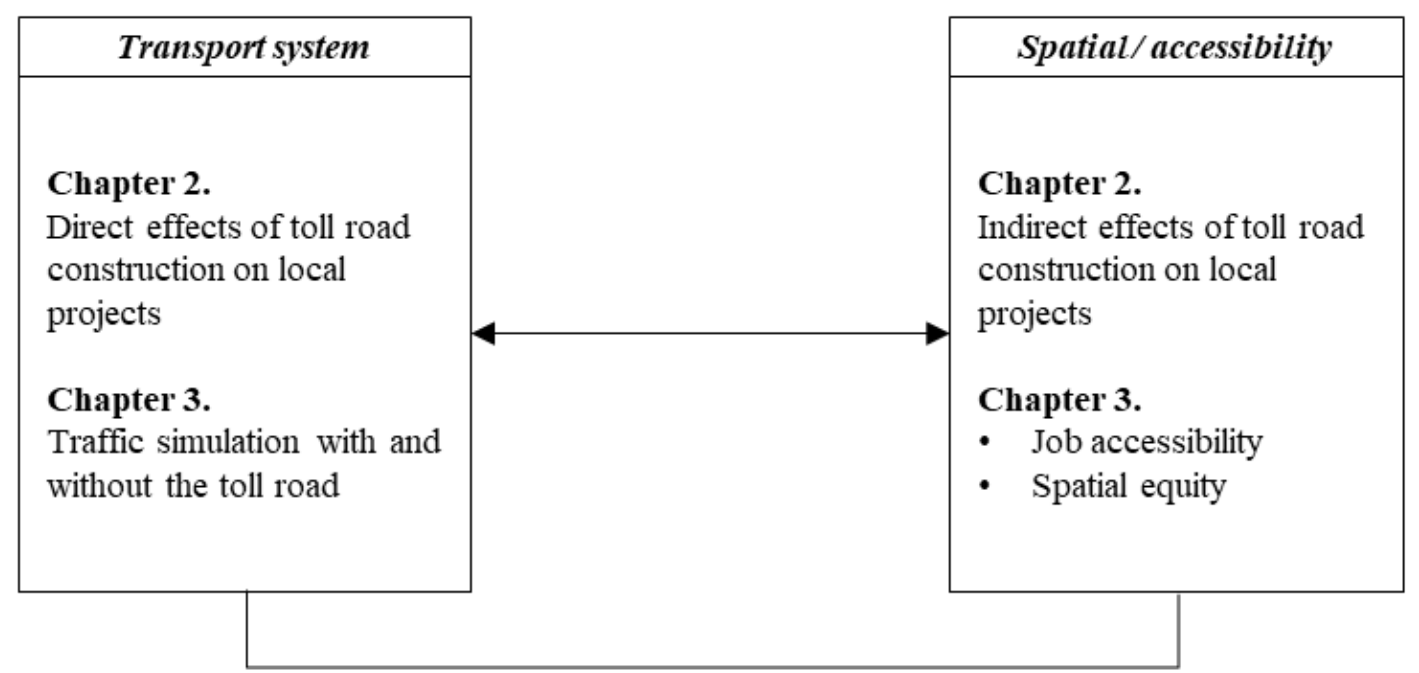

Individual level

Chapter 4.

Residential location choice

by population segment

\section{Chapter 5.}

Route and mode choices by population segment

Figure 1.3. Thesis outline 
this page is intentionally left blank 


\title{
2. Effects of toll road construction on local road projects
}

This chapter is based on the following publication: Andani, I.G.A., La Paix Puello, L., \& Geurs, K. (2019). Effects of toll road construction on local road projects in Indonesia. Journal of Transport and Land Use, 12(1), 179-199. Available online at http://dx.doi.org/10.5198/jtlu.2019.1258.

\begin{abstract}
This chapter investigates the extent to which the construction of national toll roads in the Jakarta - Bandung region in Indonesia induces the development of local road projects nearby. In doing so, we disentangle the direct and indirect supply effects by considering the year of construction and urban development, respectively. Four binary logit models were formulated to examine the direct and indirect relationships between toll road construction and local road projects. The dataset comprises 94 road projects planned or carried out between 2004 and 2016. We conducted interviews with local officials in the Jakarta-Bandung region to obtain data on the projects' decision-making process. Our modelling results show that existing and planned toll roads induce the development of local road projects both directly and indirectly. Local road projects tend to be developed in anticipation of the opening of a toll road. The changes in residential area and population around the toll roads also induce local road construction.
\end{abstract}

Keywords: toll road, local roads, decentralisation, direct effect, indirect effect 


\subsection{Introduction}

Major road infrastructure investments can have a variety of impacts. Policy makers and planners often advocate road investments to stimulate local economic and regional growth, although academic evidence indicates that political and institutional conditions are also necessary conditions for economic development (Banister \& Berechman, 2001; Forslund \& Johansson, 1995). It is well known from the literature that construction of new major roads or expansions of existing road capacity may induce travel demand and new road investments. A study on state highway expansions in the United States reveals significant induced demand and induced investment effects. It shows that US counties cope with the increasing travel demand and congestion by adding more capacity (Cervero \& Hansen, 2002), although the provision of new roads is unlikely to relieve congestion (Downs, 2000; Duranton \& Turner, 2011). Expansion of congested roads most likely will trigger drivers to change route, time of travel and travel mode to exploit the new capacity, thereby generating similar levels of congestion.

The literature on induced investments has focused on major road investments in developed countries. There is a need for a better understanding of how national road infrastructure projects induce local road projects that affect the transport and accessibility impacts of the investments. To the authors' knowledge, no study has investigated the relationship between national road investments and the decision-making for local road projects. It is particularly relevant in developing countries with decentralised government systems such as Indonesia, where the different levels of governance share the responsibility for the transport networks.

Indonesia's central government authorises investments in national roads, e.g. toll roads, while the lower-tier levels of government control local road projects. Local roads connect districts and communities, carry low traffic volumes and have the lowest speed limit. Among other things, decentralisation aims to increase local government responsiveness and improve infrastructure services at the local level. Coordination, however, has become a major concern to increase the benefits of transport investment across regions.

Several studies have examined road investment decision-making at the national level (for example, Eliasson et al., 2015; Fridstrom, 1999; Nellthorp \& Mackie, 2000; Nilsson, 1991; Nyborg, 1998; Odeck, 1996, 2010). However, to our knowledge, no study has linked national road investments to decision-making on local road investments. Yet, local roads are required to link new urban developments with major roads and thereby improve regional accessibility.

Studies in both developed and developing countries show that investments in major roads stimulate urban spatial expansion and residential growth. Land use change and population density tend to be intensified in the distance close to the roads (see, for example, Aljoufie et al., 2013; Baum-Snow, 2007; Chi, 2010; Ji et al., 2014).

Furthermore, Cervero and Hansen (2002) observed that changes in population also influence the addition of highway lane miles in California. They argued that road investments not only have stimulated travel demands, but also responded to it, as they found both significant induceddemand and induced-investment effects.

This chapter aims to examine the extent to which the construction of national toll road projects induces local road investments in Indonesia, taking urban development and local decisionmaking into account. Note that all new national toll roads in Indonesia are considered as 'major roads'; 'toll road' can therefore often be read as interchangeable with 'major road' throughout this study. The added value of this study is twofold: (1) the combination of statistical analysis, 
with spatially detailed data to perform a robust predictive model; and (2) the use of high temporal and spatial resolution to analyse ex-post toll cases in developing countries.

This chapter is structured as follows. After this introduction, Section 2.2 provides the background for this study, including a review of the direct and indirect effects of major road construction as well as the decision-making involved in local road projects. Section 2.3 explains the methodology, followed by the description of the study area and data employed in this study in Sections 2.4 and 2.5. Section 2.6 presents the results of the analysis and discusses the results. Finally, Section 2.7 contains concluding remarks and suggestions for further research.

\subsection{Theoretical framework}

In theory, major investments in transport infrastructure have both direct and indirect effects on local transport systems, and one of the aims of this study was to identify these direct and indirect effects. As neither direct nor indirect effects can occur without government involvement, this study therefore also considers the decision-making process for local road investment. Figure 2.1 presents the relationship between direct and indirect effects of major-road construction on local road projects, which will be further elaborated in this section.

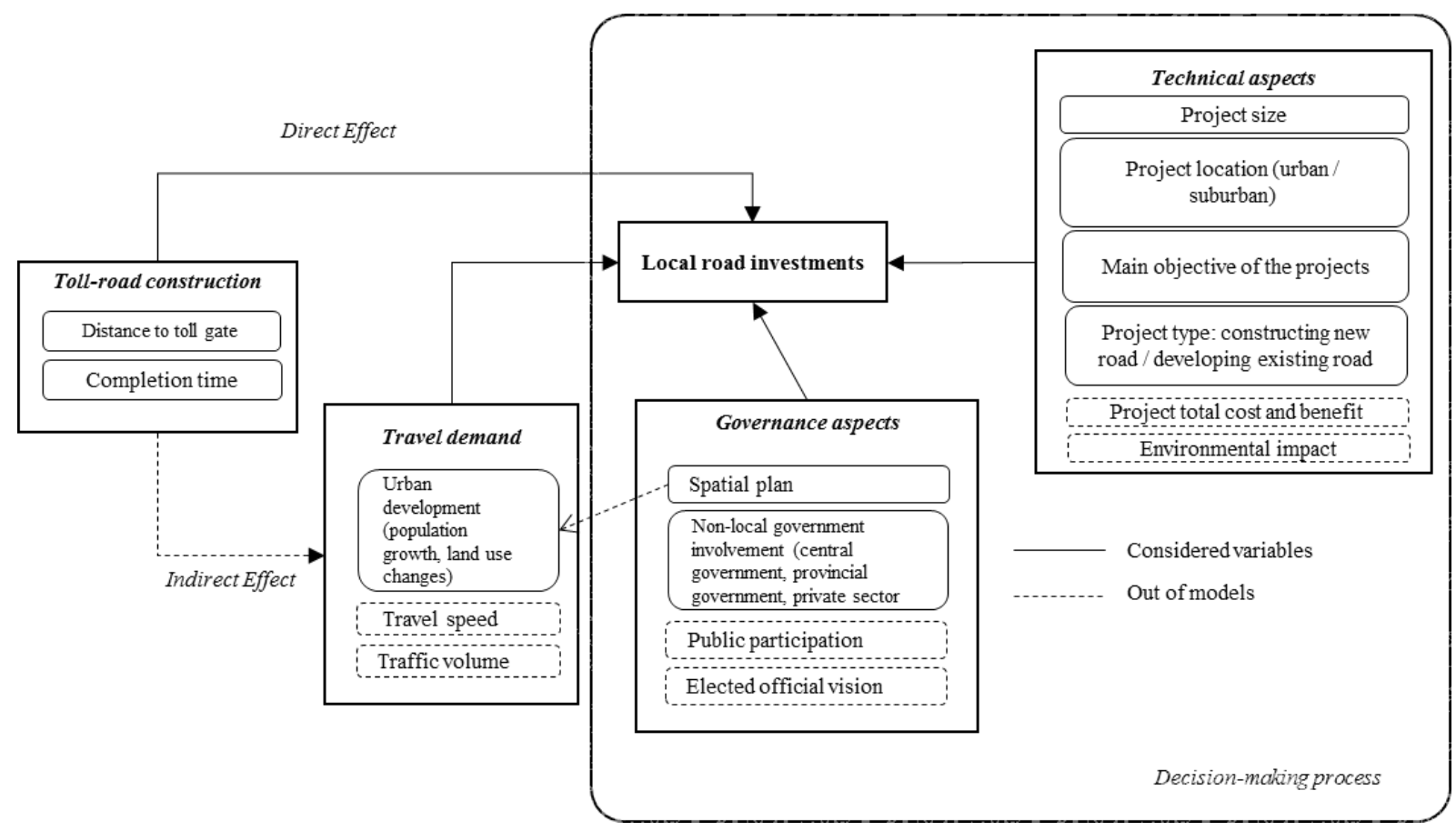

Figure 2.1. Conceptual framework

\subsubsection{Direct effects of major road construction}

Direct effects of major transport investments, such as a redistribution of traffic and congestion effects are directly related to the investments and happen directly after opening. Some direct effects of major new infrastructure on local road infrastructure occur in support of the construction of the former, meaning that there is a direct connection between the two. For example, a toll road cannot be operated without motorway links that connect the toll road with existing local roads. The construction of a major new road, therefore, has to be supported by 
the construction of these links and possibly widening and other improvements of existing roads given the expected increased traffic flow. This infrastructure dependency is a unidirectional relationship; one type of infrastructure depends on another type of infrastructure (Rinaldi, Peerenboom, \& Kelly, 2001).

According to the US Council on Environmental Quality (Avin, Cervero, Moore, \& Dorney, 2007), new infrastructure can also have direct effects on land use, which also occur almost instantly. For instance, the land taken during the construction of a major road (because the project could not be started without land use changes). Boarnet (1996) studied the direct effect of transport investment on economic activity and described it as the influence exerted in the vicinity of the new road.

\subsubsection{Indirect effects of major road construction}

New major road infrastructure can have indirect effects on local road projects as well, if it induces land use changes or other spill-over effects. Indirect effects take place later, more slowly and have a wider spatial influence (spatial spill-overs) than direct effects. The US Council of Environmental Quality (as cited by Avin et al., 2007) described indirect effects as being caused by a particular action, later in time or farther in the distance yet still reasonably foreseeable. In the literature, indirect effects are also referred to as external or secondary effects, induced effects, distributive effects or cumulative effects. The use of this terminology mostly depends on the research field.

The indirect effect occurs as the result of many interacting factors. For instance, as the completion of a major road project shortens travel time, it encourages firms and workers to move to the suburbs, where the land price tends to be lower. Therefore, more residential development follows. This urbanisation will further induce travel demand and increase the need for local transport investments. In this example, the term 'indirect effects' refers to the increased motivation to invest in local roads after the completion of a major road. Generally speaking, it may arise as a result of the growth in travel demand due to the changing land use, growing population, traffic congestion as well as damage to existing roads because of the heavier traffic.

Several studies in developing countries have indicated that changes in both built-up area and population tend to be at the proximity to highways (see, for example, Chi, 2010; Ji et al., 2014). Ghani et al. (2012), for instance, found that manufacturers located more than $10 \mathrm{~km}$ from the highway project in India benefit less than manufacturers situated closer to the project. However, to our knowledge, no study has examined the effect of urban development on transport infrastructure construction in developing countries yet. Our study therefore specifically also takes urban development into account in the identification of the effect of toll road construction on local road projects.

In addition, it is important to note that urbanisation differs across rural, suburban and urban areas (Chi, 2010). Goode and Hastings (1989) pointed out that the proximity to highway access has a positive effect on industrial locations in small metropolitan counties, but not in nonmetropolitan counties. Rephann and Isserman (1994) described similar findings and concluded that highway construction benefits urbanised areas (defined as areas with a population of more than 25,000) more than rural areas. Fridstrom and Elvik (1997) and Eliasson et al. (2015) also took this difference into account in their studies. 


\subsubsection{Decision-making on local road projects}

Decision-making on local road projects by local governments is influenced by technical and governance aspects, as highlighted in Figure 2.1.

\section{Technical aspects}

The characteristics of local road projects and the resulting benefits affect the priorities in local governmental decision-making. A local government may prefer the construction of a longer link with a greater service area (Eliasson et al., 2015; Fridstrom, 1999). Another critical factor is the nature of the road project, for instance, whether it concerns the construction of a new road or not (Fridstrom \& Elvik, 1997). Cervero and Hansen (2002) found that many urbanised regions carried out improvements to their current road networks rather than the construction of new roads.

Several studies have focused on the role of cost-benefit analysis (CBA) in decision-making on major roads. The CBA typically includes accessibility benefits, changes in externalities (emission, congestion or noise) investment cost and transport-related revenues (Eliasson et al., 2015). Eliasson and Lundberg (2012) found, for example, that CBA played a role in investment selection in Sweden and forced investment design to be more cost-efficient. Studies in Norway (Odeck, 2010) and Sweden (Nilsson, 1991) show that the decision-makers do not select projects primarily based on outcomes of CBA but focus on specific benefits such as reducing travel time, minimising accidents rates and encouraging regional developments. Mouter (2017) shows that Dutch politicians also use CBA in an opportunistic and symbolic way. In most countries, including Indonesia, cost-benefit analyses are used for the planning of major infrastructure rather than for local infrastructure, however. Therefore, to determine decision-making in local projects, we did not take into account any variables related to CBA, but directly incorporated the characteristics of the project in the model.

\section{Governance aspects}

It is often assumed that decision-making is based on a rational approach, in which decisionmakers consider all possible ways to achieve an objective. A major constraint for such a rational approach is the high degree of complexity and uncertainty that characterises the field of infrastructure. It is hard to commit to many resources for a long period without having the certainty of demand or potential effects. In addition, this complexity includes the involvement of various stakeholders with different, potentially competing interests; they will all try to influence the decision-makers. As a result, decisions about infrastructure development often rely on members of parliament or other elected officials (see Nyborg, 1998; Odeck, 1996).

The class of the road plays a role as well since this relates not only to the size of the project but also to its level of authorisation. Nilsson (1991) considered local, national and European roads in his study of the ranking of road schemes in Sweden; his findings may also apply to the case of a country's decentralised infrastructure provision, such as in Indonesia.

Local road projects, as well as other local programs, are linked to the development goals of both local and national government (stated in strategic plans) and the views of elected officials. This decision-making flow is a conventional top-down process. Nevertheless, local investments can also come about through community aspiration and participation. The process usually includes discussions involving various stakeholders, such as parliament members, community groups, academia and the private sector. 
However, the final decisions are still in the hands of public bureaucrats. The Ministry of Public Works, for example, is in charge of planning and construction of road networks as well as of water and irrigation systems. Both its annual action plan and five-year strategic plan are based on the municipalities' strategic and spatial plans. This kind of decision-making relies on planning requirements and permission. Fridstrom and Elvik (1997) also found that the status of the projects (planned and approved by Parliament but not yet started or already begun) is essential in the prioritisation of road projects.

Authorisation also largely corresponds to the source of the investments. Central transfers are the primary source of revenue $(90 \%)$ for local government in Indonesia. Local government investment also comes from other sources, namely local revenue, external and provincial grants and additional forms of income permitted by law, such as cooperation with the private sector.

As the brief preceding analysis shows, toll road construction can stimulate local road investment directly or indirectly. We decided to take a modelling approach to investigate this further and to adopt factors that previous studies found to be significant in explaining the effects of the construction of highways. This study fills the gap in terms of how the construction of major roads could affect local roads construction.

\subsection{Methodology}

We applied a standard binary logit model to assess the probability of local road project development. To test the hypothesis that national toll roads induce the construction of local road projects, directly and indirectly, we formulated four models and composed each model with different independent variables. The dependent variable of all modes is binary of the presence of local road projects. Meanwhile, the independent variables are including the toll road characteristics, urban development and decision-making factors.

The first model is the base model, which attempts to describe the decision-making for local road projects. This model is composed of several independent variables related to investment cost, the length of the road project, location, road type and government involvement. The second model is the direct effect model, in which toll road construction is assumed to affect local road projects directly. The second model is an extension of the base model. It includes variables of the year gap between the construction year of local road projects and the opening year of the closest toll road gate, and the distance between toll gate and the road project. The third model is the indirect effect model, which assumes that urban development triggers local roads construction. Thus, the third model improves the base model by including variables of residential and industrial land use changes, and population change. Finally, the fourth model is the composite model, which combines the direct and indirect effect models.

We created three datasets with square cell sizes of $100 \mathrm{~m}^{2}, 500 \mathrm{~m}^{2}$ and $1 \mathrm{~km}^{2}$ with $6,098,1,224$ and 631 observations, respectively. Using a smaller cell size enabled us to incorporate small projects as well. Larger cells, on the other hand, allow easy identification of changes in urban development. A further selection of the dataset then was done on the basis of land use and population changes data, which left us with 5,994, 1,202 and 619 observations in the three datasets. These numbers are sufficiently large for statistical analysis. 
The observed cells showed in Figure 2.2. Blue cells containing the link of the projects are treated as an observation ${ }^{1}$ in the model. The probability of a cell to have a a local road project (i) or not $(j)$ can be formulated as follows (Ben-Akiva \& Lerman, 1985):

$$
P_{(i)}=\frac{e^{\mu \beta^{\prime} x_{i n}}}{e^{\mu \beta^{\prime} x_{i n}}+e^{\mu \beta^{\prime} x_{j n}}}
$$

Here, $\beta^{\prime}$ is the vector of the unknown parameters, $x$ is the vector of attributes, $n$ is the number of cell and $\mu$ is a positive scale parameter. The value of $\mu$ is fixed to 1 , as in any binary or multinomial logit model (Train, 2009).

The logit model has two alternatives: 'local project' and 'national project'. Then, the model estimates the probability of having either a local or a national project in the cell after controlling by other toll related variables. The general objective of this study examines the extent to which the construction of national toll road projects induces local road investments, with a case study in Indonesia. These projects are linked to the construction of the toll by other variables, such as 'year gap' and 'distance to toll gate'. Via the logit model we can investigate how the existence of the toll affects the construction of the projects.

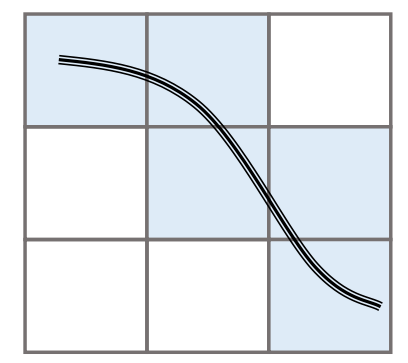

Figure 2.2. Example of observed cells and the project's link

We chose the parsimonious (minimum number of predictor variables with great explanatory predictive power) model as the preferred model and used those variables that had a confidence level of $95 \%$ in the model. The estimation of arc (direct) elasticities with respect to independent variables are also of interest in this study, to show the relationship between a percent change in independent variables and the percent change in the probability of realisation or funding of local road projects. We modified specific continuous variables by $1 \%, 5 \%$ and $10 \%$, keeping other variables constant and calculated the average arc elasticity with the following formula (Bierlaire, 2017),

\footnotetext{
${ }^{1}$ As the cells (observations) are derived from the road projects itself, each cell contains the values of the variables related to the project on the cell. Also, because of the derivation, several cells could have the same value of the analysed variable.
} 


$$
\bar{E}_{X_{i n k}}^{P_{n}(i)}=\frac{1}{N} \sum_{n=1}^{N} \frac{\Delta P_{n}(i)}{\Delta X_{i n k}} \frac{X_{i n k}}{P_{n}(i)}
$$

Here, $X_{\text {ink }}$ is the value of each independent variable $k$ in each observation $n ; \Delta X_{\text {ink }}$ is the value of the change in variable $k$ after the modification. $P_{n}(i)$ is the probability of having local road projects and $\Delta P_{n}(i)$ is the change in the probability after the increment of $x$.

\subsection{Study area}

In Indonesia, public road infrastructure such as road, is managed in a decentralised administration and followed a hierarchical system. According to its status and authority, public roads can be classified to, (1) national roads, (2) provincial roads, (3) regency roads, (4) municipal roads and (5) village roads. In this study, the last three are simplified as local roads.

A state-owned enterprise of Indonesia manages most toll roads. On the other hand, local roads are authorised by the lowest level of government (regency or municipality). The construction of the roads should follow this hierarchy. For instance, municipal (local) roads are to some extent not allowed to link to national roads directly.

Toll road and local road construction have different funding sources. Although toll roads require larger investments than local roads, they also have a higher rate of return, as users pay a fee to use a toll road, but do not pay for the use of local roads. Therefore, the private sector prefers to invest in toll roads rather than in local roads.

Our study area covers 13 municipalities in the corridor of Jakarta and Bandung as shown in Figure 2.3. The name 'Cipularang' is a contraction of 'Cikampek, Purwakarta and Padalarang.' This toll road connects Jakarta and Bandung by connecting the Jakarta-Cikampek toll road and the Padalarang-Cileunyi (Padaleunyi) toll road (of which the Pasteur toll road in Bandung is also a part). The Cipularang toll road has five gates; three gates are located in the West Bandung Regency, and the other two are in the Purwakarta Regency. There are many toll roads in this area, such as the Jakarta-Cikampek toll road (built in 1986), the Jagorawi toll road (built in 1983) and the Cikampek-Palimanan toll road (built in 2015). Several more toll roads are planned for construction in the study area, such as toll road sections that connect Bogor and Cianjur.

\subsection{Data}

Time series of local road projects data are difficult to obtain as data on local road projects is only available in each municipality. We, therefore, based this study on the limited available data from local municipalities, GIS data for the period 2000 to 2013 and semi-structured interviews with thirteen local officials from each municipality in the Jakarta - Bandung region. During the interviews, local officials added or eliminated local road projects from our dataset, if they did or did not consider the projects to be connected with the toll road (in terms of traffic). The interviews also explored the decision-making of the projects, specifically 1 ) whether the construction of the toll road was part of the local road project decision, 2) the main motivation for the investment (connecting newly developed areas, reducing travel time or increasing traffic safety) and 3) the involvement of non-local government. 


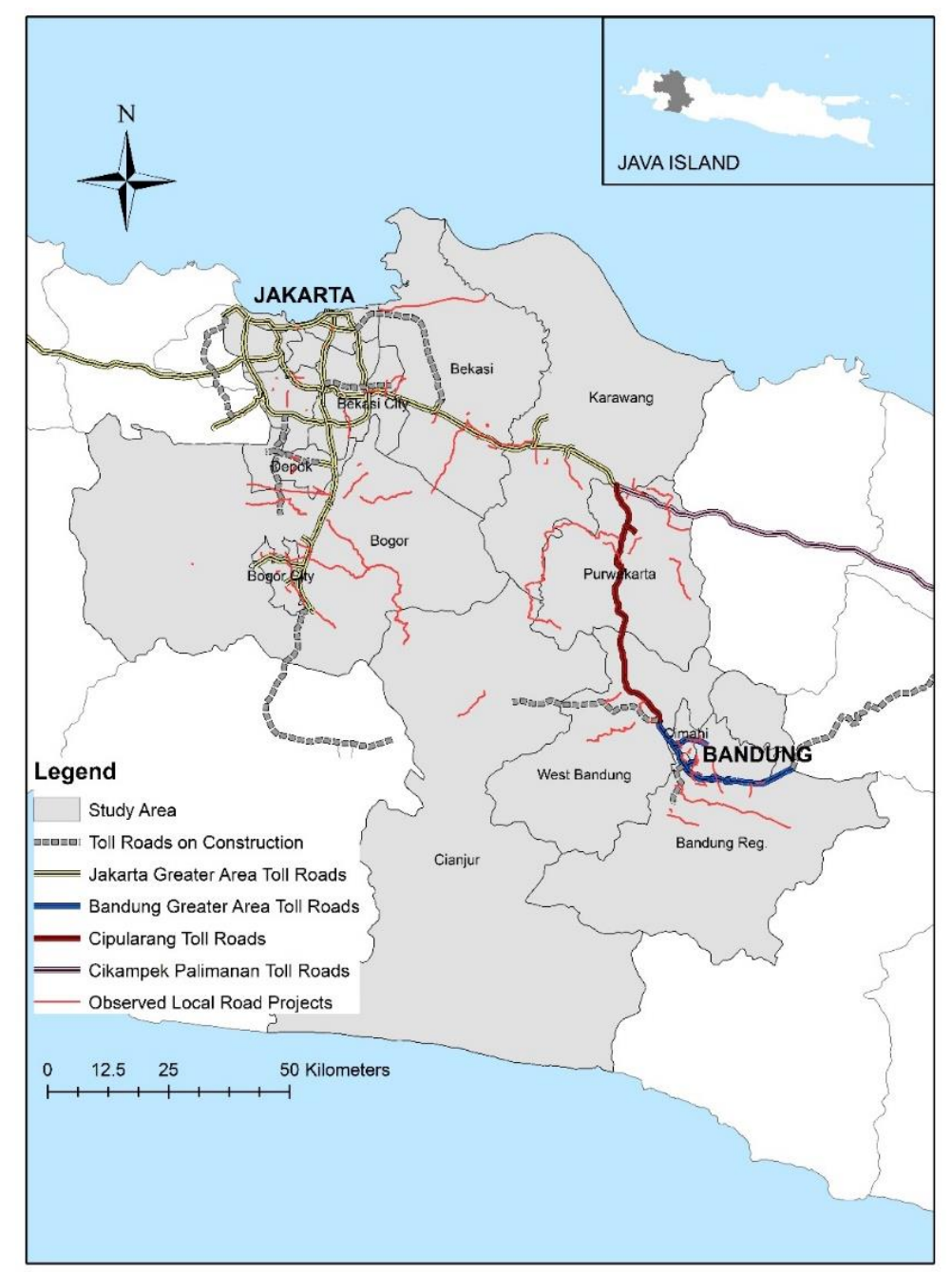

Figure 2.3. Case study area

This data collection led to a selection of 96 projects (depicted in Figure 2.3), of which $72 \%$ had been completed, and the remainder were at the time of data collection (mid-2016) in the planning stage (with funding secured) or under construction. The projects included in this study are projects, which are aimed to improve the capacity of the current network or improve connectivity to a toll road. Maintenance projects are excluded from this study. All were located within a distance of $18 \mathrm{~km}$ to toll road access and carried out between 2000 and 2016. In our study, local projects are oversampled (81\%) relative to toll roads, and $19 \%$ are non-local projects (national and provincial). Non-local road projects were included to examine characteristic differences between local and non-local road projects. Tables 2.1 and 2.2 describe the variables used in this research. A detailed explanation of the variables follows in the sections below. 


\subsubsection{Direct effect variables}

We investigated the direct effect of toll road construction with two variables: 1) distance to toll gate and 2) year gap between the construction year of the local road project and the opening year of the closest toll road gate. Distance to the toll gate is the shortest Euclidean distance from the road to the toll gates (variable no. 3 in Table 2.1). The average of closest distance between non-local (national or provincial) road projects and the toll gate is $2.9 \mathrm{~km}$. On the other hand, $3.4 \mathrm{~km}$ is the average of closest distance between all projects and the toll gate. National and provincial roads tend to locate within proximity to the toll gate. We distinguished three categories of the project's proximity to the toll gates: long (more than $3.4 \mathrm{~km}$ ), medium (2.9 to $3.4 \mathrm{~km}$ ) and short distance (less than $2.9 \mathrm{~km}$ ). We used these categories as binary input for the model (variables No. 1-3 in Table 2.2).

The variable 'year gap' (variables No. 1 and 2 in Table 2.1) is obtained by subtracting the (start) construction year of the project and the opening year of the closest toll gate, either of an already existing toll road or one that was planned. Some road links consisted of several sections with different years of construction; in that case, they were considered different projects. Subtracting the year of the toll gate's opening from the year of the local project's construction beginning yields positive and negative values. As it is more convenient and enables a more precise interpretation of the results, we separated this variable into two variables, one with a positive value and one with a negative value. Positive year gap means that a local road is constructed after or at the same time the toll gate opened. On the contrary, the negative year gap means a local road started to construct before the opening of the closest toll gate and finished before, at the same time or after the opening of the toll gate.

\subsubsection{Indirect effect variables}

Urban development is represented by variables of residential land use, industrial land use and population change. Land use change data of the thirteen municipalities is available in the year 2004 and 2013. We converted the parcel-level land use data to a raster format. There is some remaining error, as a result of the manual digitisation and the lower level of accuracy associated with earlier mapmaking. The case study area covers approximately $15,250 \mathrm{~km}^{2}$. We partitioned it into a grid of cells of $10 \mathrm{~m}$ by $10 \mathrm{~m}$ and assigned a land use type to each cell according to its dominant land use.

Between 2004 and 2013, the residential land use increased by $2.5 \%$ and the industrial land use by $1 \%$. As Figure 2.4 shows, emerging industrial development tend to be located along the toll road, especially in the municipalities of Karawang and Bekasi. It is likely that the previous land use was rice field or plantation area since this type of land use decreased by $4.3 \%$.

Furthermore, we used population change data for two periods in the models, namely for the period 2000 to 2010 and 2010 to 2015 . This data is in the form of a raster with $100-\mathrm{m}$ square cells. The usage of population change in this study is to specifically address population growth on decisions to build or expand local roads. Using three time points of population number in the model could raise multicollinearity. Moreover, still, we expect that variables of population and residential land use changes to be correlated to each other. However, we have found no correlation between both variables in this case. Therefore, they are incorporated in the model. 


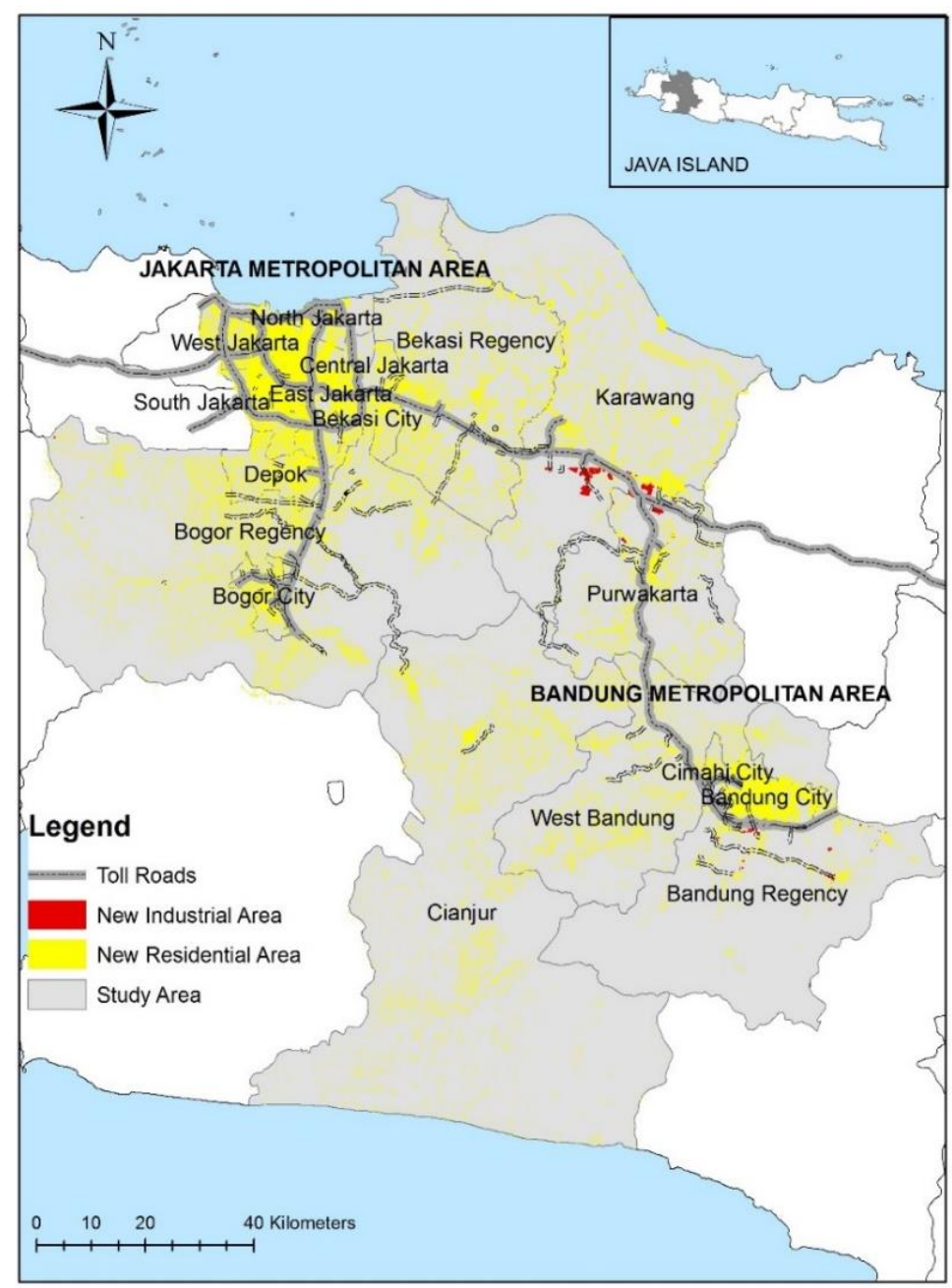

Figure 2.4. Residential and industrial area developments (2004-2013)

\subsubsection{Decision-making process variables}

As described earlier, we conducted semi-structured interviews to collect project characteristics and related decision-making factors. We then converted these variables into binary data. We gathered other project characteristics from various sources. Data on project length (in kilometres) and construction year were collected from the local government action plan documents and local electronic procurement service websites. We also checked if the projects were already included in the local long-term spatial plan (20 years). The term of these spatial plan varies; for instance, the spatial plan of Bandung City is for the period 2011-2031, whereas Jakarta's is for the period 2010-2030. These variables were also entered into the models as binary data.

Our models take the spatial distribution into account as well (whether a project is located in an urban or suburban area). We followed the distinction made by the West Java Provincial Government on the urban, suburban and rural areas, according to the population density and the proportion of built-up area (WJP-MDM, 2013). The whole area of Jakarta is characterised as an urban area (more than 500 people per $\mathrm{km}^{2}$ ). Tables 2.1 and 2.2 present the descriptions of the explanatory variables. 
Table 2.1. Description of quantitative variables

\begin{tabular}{|c|c|c|c|c|c|c|c|c|}
\hline \multirow[b]{2}{*}{ No. } & \multirow[b]{2}{*}{ Variables } & \multirow[b]{2}{*}{ Definition } & \multicolumn{3}{|c|}{ Mean } & \multirow[b]{2}{*}{ Min } & \multirow[b]{2}{*}{ Max } & \multirow[b]{2}{*}{$\begin{array}{l}\text { St. } \\
\text { dev }\end{array}$} \\
\hline & & & $\begin{array}{l}\text { Non- } \\
\text { local }\end{array}$ & Local & $\begin{array}{c}\text { All } \\
\text { projects }\end{array}$ & & & \\
\hline \multicolumn{9}{|c|}{ Direct effect model } \\
\hline 1 & YEARGAP_POS & $\begin{array}{l}\text { Positive year } \\
\text { gap between } \\
\text { toll road } \\
\text { construction } \\
\text { and project }\end{array}$ & 3.6 & 10.6 & 13.2 & 0.0 & 39.0 & 10.9 \\
\hline 2 & YEARGAP_NEG & $\begin{array}{l}\text { Negative } \\
\text { year gap } \\
\text { between toll } \\
\text { road } \\
\text { construction } \\
\text { and project }\end{array}$ & 0.8 & 0.4 & 0.4 & 0.0 & 14.0 & 1.9 \\
\hline 3 & DISTANCE & $\begin{array}{l}\text { The shortest } \\
\text { distance } \\
\text { between toll } \\
\text { gate and } \\
\text { project link } \\
\text { (in kilometre) }\end{array}$ & 2.9 & 3.7 & 4.0 & 0.1 & 18.5 & 3.7 \\
\hline \multicolumn{9}{|c|}{ Indirect effect model } \\
\hline 4 & RESIDENTIAL & $\begin{array}{l}\text { Change in } \\
\text { residential } \\
\text { land use in } \\
\text { each cell (in } \\
\text { hectares) }\end{array}$ & 0.0 & 0.0 & 0.0 & -1.0 & 1.0 & 0.3 \\
\hline 5 & INDUSTRIAL & $\begin{array}{l}\text { Change in } \\
\text { industrial } \\
\text { land use in } \\
\text { each cell (in } \\
\text { hectares) }\end{array}$ & 0.0 & 0.0 & 0.0 & -1.0 & 1.0 & 0.2 \\
\hline 6 & POPCHANGE1015 & $\begin{array}{l}\text { Change in } \\
\text { population } \\
\text { number in } \\
\text { each cell, } \\
\text { between } \\
2010 \text { and } \\
2015\end{array}$ & 6.7 & 10.3 & 7.3 & 0.0 & 120.0 & 10.9 \\
\hline 7 & POPCHANGE0010 & $\begin{array}{l}\text { Change in } \\
\text { population } \\
\text { number in } \\
\text { each cell, } \\
\text { between } \\
2000 \text { and } \\
2010\end{array}$ & 14.5 & 22.8 & 15.7 & -109.0 & 579.0 & 42.9 \\
\hline \multicolumn{9}{|c|}{ Decision-making (base model) } \\
\hline 8 & COSTPERKM & $\begin{array}{l}\text { Non- } \\
\text { discounted } \\
\text { investment } \\
\text { costs per } \\
\text { kilometre of }\end{array}$ & 17.0 & 13.4 & 16.5 & 0.0 & 1213.6 & 74.0 \\
\hline
\end{tabular}




\begin{tabular}{|l|c|l|r|r|r|r|r|c|}
\hline \multirow{2}{*}{ No. } & \multirow{2}{*}{ Variables } & Definition & $\begin{array}{c}\text { Non- } \\
\text { local }\end{array}$ & Local & $\begin{array}{c}\text { All } \\
\text { projects }\end{array}$ & Min & Max & $\begin{array}{c}\text { St. } \\
\text { dev }\end{array}$ \\
\hline & & $\begin{array}{l}\text { road (in 10 } \\
\text { Indonesian } \\
\text { Rupiah) }\end{array}$ & & & & & & \\
\hline 9 & LENGTH & $\begin{array}{l}\text { Length of a } \\
\text { road project } \\
\text { (in } \\
\text { kilometres) }\end{array}$ & 21.2 & 9.4 & 19.5 & 0.1 & 51.3 & 17.6 \\
\hline
\end{tabular}

Table 2.2. Description of binary variables

\begin{tabular}{|c|c|c|c|c|c|c|}
\hline \multirow[b]{2}{*}{ No. } & \multirow[b]{2}{*}{ Variables } & \multirow[b]{2}{*}{ Definition } & \multirow{2}{*}{ Category } & \multicolumn{3}{|c|}{ Percentage } \\
\hline & & & & $\begin{array}{l}\text { Non- } \\
\text { local }\end{array}$ & Local & $\begin{array}{l}\text { All } \\
\text { projects }\end{array}$ \\
\hline \multicolumn{7}{|c|}{ Direct effect model } \\
\hline \multirow[b]{2}{*}{1} & \multirow{2}{*}{$\begin{array}{l}\text { DISTANCE_ } \\
\text { SHORT }\end{array}$} & \multirow{2}{*}{$\begin{array}{l}\text { The shortest } \\
\text { distance between } \\
\text { toll gate and project } \\
\text { link is less than } 2.9 \\
\mathrm{~km}\end{array}$} & 0 & $2.9 \%$ & $50.9 \%$ & $53.8 \%$ \\
\hline & & & 1 & $12.0 \%$ & $34.1 \%$ & $46.2 \%$ \\
\hline \multirow[b]{2}{*}{2} & \multirow[b]{2}{*}{ DISTANCE_MID } & \multirow{2}{*}{$\begin{array}{l}\text { The shortest } \\
\text { distance between } \\
\text { toll gate and project } \\
\text { link is between } 2.9 \\
\text { and } 3.4 \mathrm{~km}\end{array}$} & 0 & $14.9 \%$ & $82.7 \%$ & $97.6 \%$ \\
\hline & & & 1 & $0.0 \%$ & $2.4 \%$ & $2.4 \%$ \\
\hline \multirow[b]{2}{*}{3} & \multirow[b]{2}{*}{$\begin{array}{l}\text { DISTANCE_ } \\
\text { LONG }\end{array}$} & \multirow{2}{*}{$\begin{array}{l}\text { The shortest } \\
\text { distance between } \\
\text { toll gate and project } \\
\text { link is more than } \\
3.4 \mathrm{~km}\end{array}$} & 0 & $12.0 \%$ & $36.5 \%$ & $48.5 \%$ \\
\hline & & & 1 & $2.9 \%$ & $48.6 \%$ & $51.5 \%$ \\
\hline \multicolumn{7}{|c|}{ Decision-making (base model) } \\
\hline \multirow{2}{*}{4} & \multirow{2}{*}{ URBAN_AREA } & \multirow{2}{*}{ Urbanised areas } & 0 & $0.1 \%$ & $37.5 \%$ & $37.6 \%$ \\
\hline & & & 1 & $14.8 \%$ & $47.6 \%$ & $62.4 \%$ \\
\hline \multirow{2}{*}{5} & \multirow{2}{*}{ NEWROAD } & \multirow{2}{*}{$\begin{array}{l}\text { The project is a new } \\
\text { link }\end{array}$} & 0 & $11.0 \%$ & $16.4 \%$ & $27.3 \%$ \\
\hline & & & 1 & $4.0 \%$ & $68.7 \%$ & $72.7 \%$ \\
\hline \multirow[b]{2}{*}{6} & \multirow{2}{*}{ MAINROAD } & \multirow{2}{*}{$\begin{array}{l}\text { The project is part } \\
\text { of a functional main } \\
\text { road }^{2}\end{array}$} & 0 & $0.2 \%$ & $45.8 \%$ & $45.9 \%$ \\
\hline & & & 1 & $14.8 \%$ & $39.3 \%$ & $54.1 \%$ \\
\hline \multirow{2}{*}{7} & \multirow{2}{*}{ TT_REDUCE } & \multirow{2}{*}{$\begin{array}{l}\text { The main aim of the } \\
\text { project is to reduce } \\
\text { travel time }\end{array}$} & 0 & $10.4 \%$ & $21.6 \%$ & $32.0 \%$ \\
\hline & & & 1 & $4.5 \%$ & $63.5 \%$ & $68.0 \%$ \\
\hline \multirow[t]{2}{*}{8} & \multirow{2}{*}{ NEWACCESS } & \multirow{2}{*}{$\begin{array}{l}\text { The main aim of the } \\
\text { project is }\end{array}$} & 0 & $6.7 \%$ & $67.1 \%$ & $73.8 \%$ \\
\hline & & & 1 & $8.3 \%$ & $18.0 \%$ & $26.2 \%$ \\
\hline
\end{tabular}

${ }^{2}$ In the case of Indonesia, main roads are connecting primary areas which consist of main activities, such as regional industrial area, airport, regional market, harbor, airport and regional-scaled commercial area. 


\begin{tabular}{|c|c|c|c|c|c|c|}
\hline \multirow{3}{*}{ No. } & \multirow{3}{*}{ Variables } & \multirow{3}{*}{$\begin{array}{l}\text { Definition } \\
\text { connecting new } \\
\text { areas }\end{array}$} & \multirow{2}{*}{ Category } & \multicolumn{3}{|c|}{ Percentage } \\
\hline & & & & $\begin{array}{l}\text { Non- } \\
\text { local }\end{array}$ & Local & $\begin{array}{l}\text { All } \\
\text { projects }\end{array}$ \\
\hline & & & & & & \\
\hline \multirow{2}{*}{9} & \multirow{2}{*}{ CENTRAL } & \multirow{2}{*}{$\begin{array}{l}\text { Central government } \\
\text { involvement in the } \\
\text { project }\end{array}$} & 0 & $7.8 \%$ & $33.1 \%$ & $40.8 \%$ \\
\hline & & & 1 & $7.2 \%$ & $52.0 \%$ & $59.2 \%$ \\
\hline \multirow{2}{*}{10} & \multirow{2}{*}{ PROVINCIAL } & \multirow{2}{*}{$\begin{array}{l}\text { Provincial } \\
\text { government } \\
\text { involvement in the } \\
\text { project }\end{array}$} & 0 & $6.2 \%$ & $63.3 \%$ & $69.6 \%$ \\
\hline & & & 1 & $8.7 \%$ & $21.7 \%$ & $30.4 \%$ \\
\hline \multirow{2}{*}{11} & \multirow{2}{*}{ PRIVATE } & \multirow{2}{*}{$\begin{array}{l}\text { Private sector } \\
\text { involvement in the } \\
\text { project }\end{array}$} & 0 & $13.3 \%$ & $64.8 \%$ & $78.1 \%$ \\
\hline & & & 1 & $1.6 \%$ & $20.2 \%$ & $21.9 \%$ \\
\hline \multirow{2}{*}{12} & \multirow{2}{*}{ SPATIAL_PLAN } & \multirow{2}{*}{$\begin{array}{l}\text { Projects included in } \\
\text { local spatial plan }\end{array}$} & 0 & $3.0 \%$ & $12.8 \%$ & $15.7 \%$ \\
\hline & & & 1 & $12.0 \%$ & $72.3 \%$ & $84.3 \%$ \\
\hline
\end{tabular}

\subsection{Results and discussion}

\subsubsection{Modelling local road projects}

We tested three datasets with different geographical scales $\left(100 \mathrm{~m}^{2}, 500 \mathrm{~m}^{2}\right.$ and $1 \mathrm{~km}^{2}$ cells $)$ to select the most suitable data set. The set of $100 \mathrm{~m}^{2}$ cells and 5,994 observations yielded the best goodness of fit. We, therefore, used this dataset to model the direct and indirect effects of toll road construction on local road projects.

We estimated the direct effect model by incorporating distance to toll gate and the year gap between the construction of a local project and the construction of a toll road as variables. In the indirect effect model, we replaced the toll road construction variables with urban development variables, such as residential land use, industrial land use and population changes. The direct and indirect models were combined in the composite model to achieve better data representation.

We then generated four parsimonious models, by keeping only those parameters with $p<0.05$. The p-values are used to determine the level of significance of each coefficient. Table 2.3 lists the results of the logit models. The parameters are estimated from the logit model. The value of the coefficient of each parameter shows the log of the odds of having a local road project with respect to the variables.

Parameters of 'travel time reduction' and 'new roads' were found to be correlated to each other, as well as 'spatial plan' and 'length of the project'. Bigger projects should be planned ahead and included in the spatial as they also attract greater interest. Putting the aforementioned variables as single independent variables in the model resulted in one of the parameters could not be identified correctly (i.e. the parameter unexpectedly to be negative or insignificant). Thus, the product of those variables is incorporated into the model.

In Table 2.3, we can see that the direct effect model has a higher value of $R^{2}(0.85)$ than the indirect effect model (0.62). Among the four models, the composite model has the highest $\mathrm{R}^{2}$ statistic and considered the most representative model. A way to ascertain the significance of adding more parameters in the model is to use a log-likelihood ratio test $(L L R)$ and compare the 
final log-likelihood between the restricted model and the unrestricted model. The test statistic is:

$$
L L R=-2\left(\mathrm{~L}\left(\beta_{\mathrm{R}}\right)-\mathrm{L}\left(\beta_{\mathrm{U}}\right)\right)
$$

Where $\beta_{\mathrm{R}}$ denotes the estimated coefficients of the restricted model and $\beta_{\mathrm{U}}$ denotes the estimated coefficients of the unrestricted model. Restricted log-likelihood $\left(\mathrm{L}\left(\beta_{\mathrm{R}}\right)\right)$ reflects the model estimation from the initial explanatory variables, in this case, variables included in the base model. Furthermore, unrestricted $\log$-likelihood $\left(\mathrm{L}\left(\beta_{\mathrm{U}}\right)\right)$ is the log-likelihood obtained by adding parameters to the base (restricted) model. The log-likelihood is calculated using this formula (Train, 2009):

$$
\mathrm{L}(\beta)=\sum_{n=1}^{N} \sum_{i} y_{n i} \ln \left(P_{n i}\right)
$$

where $y_{n i}=1$ if there is a local road project in the cell observed and zero otherwise and $P_{n i}$ is simply the probability of having a local project in each cell. The result of $L L R$ can then be tested against the chi-squared $\left(\chi^{2}\right)$ distribution with $K_{U}-K_{R}$ degrees of freedom (df), where $K_{U}$ and $K_{R}$ are the number of parameters in the restricted and unrestricted model respectively.

The bottom row in Table 2.3 lists the critical values of the chi-square distribution at the $95 \%$ confidence level of each model $\left(\chi_{0.05}^{2}\right)$. Since in all three models, $L L R>\chi_{0.05}^{2}$, then we can reject the null hypothesis and conclude that adding parameters of the toll road and urban development significantly improved the model.

Table 2.3. Logit model results $(\mathrm{N}=5,994)$

\begin{tabular}{|l|c|c|c|c|c|c|c|c|}
\hline \multirow{2}{*}{ Parameters } & \multicolumn{2}{|c|}{ Base model } & \multicolumn{2}{c|}{$\begin{array}{c}\text { Direct effect } \\
\text { model }\end{array}$} & \multicolumn{2}{c|}{$\begin{array}{c}\text { Indirect effect } \\
\text { model }\end{array}$} & \multicolumn{2}{c|}{ Composite model } \\
\cline { 2 - 10 } & Coef. & $p$ & Coef. & $p$ & Coef. & $p$ & Coef. & $p$ \\
\hline YEARGAP_POS & - & - & 0.18 & 0.00 & - & - & 0.16 & 0.00 \\
\hline YEARGAP_NEG & - & - & -1.04 & 0.00 & - & - & -1.18 & 0.00 \\
\hline DISTANCE & - & - & 0.54 & 0.01 & - & - & 0.49 & 0.01 \\
\hline DISTANCE_LONG & - & - & 6.89 & 0.00 & - & - & 7.46 & 0.00 \\
\hline RESIDENTIAL & - & - & - & - & 0.65 & 0.00 & 0.77 & 0.00 \\
\hline POPCHG1015 & - & - & - & - & 0.02 & 0.00 & 0.05 & 0.00 \\
\hline POPCHG0010_POS & - & - & - & - & - & - & 0.59 & 0.00 \\
\hline POPCHG0010_NEG & - & - & - & - & - & - & -0.51 & 0.00 \\
\hline INDUSTRIAL & - & - & - & - & 0.54 & 0.03 & - & - \\
\hline URBAN_AREA & -4.12 & 0.00 & -5.34 & 0.00 & -4.29 & 0.00 & -5.43 & 0.00 \\
\hline COSTPERKM & 0.01 & 0.00 & 0.05 & 0.00 & 0.01 & 0.00 & 0.05 & 0.00 \\
\hline CENTRAL & -1.58 & 0.00 & -8.21 & 0.00 & -1.47 & 0.00 & -8.27 & 0.00 \\
\hline PROVINCIAL & -1.72 & 0.00 & -8.59 & 0.00 & -1.75 & 0.00 & -8.86 & 0.00 \\
\hline $\begin{array}{l}\text { TTREDUCE* } \\
\text { NEWROAD }\end{array}$ & 2.14 & 0.00 & 3.71 & 0.00 & 2.23 & 0.00 & 4.27 & 0.00 \\
\hline $\begin{array}{l}\text { SPATIAL_PLAN* } \\
\text { LENGTH }\end{array}$ & 0.05 & 0.00 & 0.05 & 0.00 & 0.06 & 0.00 & 0.06 & 0.00 \\
\hline
\end{tabular}




\begin{tabular}{|c|c|c|c|c|c|c|c|c|}
\hline \multirow{2}{*}{ Parameters } & \multicolumn{2}{|c|}{ Base model } & \multicolumn{2}{|c|}{$\begin{array}{c}\text { Direct effect } \\
\text { model }\end{array}$} & \multicolumn{2}{|c|}{$\begin{array}{l}\text { Indirect effect } \\
\text { model }\end{array}$} & \multicolumn{2}{|c|}{ Composite model } \\
\hline & Coef. & $p$ & Coef. & $p$ & Coef. & $p$ & Coef. & $p$ \\
\hline Constant & 5.30 & 0.00 & 6.80 & 0.00 & 5.09 & 0.00 & 6.29 & 0.00 \\
\hline $\mathrm{L}(\beta)$ & \multicolumn{2}{|c|}{-1631.26} & \multicolumn{2}{|c|}{-609.93} & \multicolumn{2}{|c|}{-1598.09} & \multicolumn{2}{|c|}{-558.12} \\
\hline $\mathrm{R}^{2}$ & \multicolumn{2}{|c|}{0.61} & \multicolumn{2}{|c|}{0.85} & \multicolumn{2}{|c|}{0.62} & \multicolumn{2}{|c|}{0.86} \\
\hline$K$ & \multicolumn{2}{|c|}{7} & \multicolumn{2}{|c|}{11} & \multicolumn{2}{|c|}{10} & \multicolumn{2}{|c|}{15} \\
\hline$L L R$ & \multicolumn{2}{|c|}{2042.66} & \multicolumn{2}{|c|}{2125.62} & \multicolumn{2}{|c|}{2059.28} & \multicolumn{2}{|c|}{2146.28} \\
\hline$\chi_{0.05}^{2}$ & \multicolumn{2}{|c|}{ - } & \multicolumn{2}{|c|}{$\begin{array}{c}9.49 \\
\text { (diff. } \mathrm{df}=4)\end{array}$} & \multicolumn{2}{|c|}{$\begin{array}{c}7.82 \\
\text { (diff. } d f=3)\end{array}$} & \multicolumn{2}{|c|}{$\begin{array}{c}15.51 \\
(\text { diff. } \mathrm{df}=8)\end{array}$} \\
\hline
\end{tabular}

\section{Direct effect of toll road construction on local road projects}

In the direct effect model, the variable 'positive year gap' between the construction of the toll roads and the local roads has a positive value $(0.16)$ in explaining local road projects. It indicates that local road projects tend to be realised after the construction of a toll road. The negative year gap variable shows a significantly negative value (-1.18). This, on the other hand, signifies that local road projects started before toll road construction tend to be realised close to the construction year of a toll road, apparently in anticipation of the effects of the planned toll road.

Moreover, constructed and planned local road projects tend to be located farther from the toll gates than national or provincial roads (which often actually contain the toll gates), explained by the positive and significant coefficient value of the distance to the toll gates (0.49). It is also strengthened by the result of a dummy variable for longer distances, which shows a positive value (7.46). The descriptive statistic shows that the average closest distance between non-local (national or provincial) road projects and the toll road gate is $2.9 \mathrm{~km}$ and the distance between local road projects and the toll gate is $3.5 \mathrm{~km}$. This shows that local road projects are located farther away from the toll gates, followed the hierarchy system of public roads as discussed in Section 2.4 about the study area.

\section{Indirect effect of toll road construction on local road projects}

The indirect effect model represents urban development and characterised by the variables of industrial land use, residential land use and population changes. The construction of local road projects is found to be influenced by industrial land use change, as it is shown in the indirect effect model (with a value of 0.54), although the variable is not identifiable in the composite model.

Changes in residential land use and population size between 2010 and 2015 can explain local road projects in the composite model (with values of 0.77 and 0.05 , respectively). On the other hand, population change between 2000 and 2010 has no impact on the models. This is caused by the fact that there is a population decrease in several cells in this period. On that account, we distinguished the positive and negative changes in population in that period. As expected, both new variables are significant to affect local road construction, as shown in the composite model. Increased population has a positive effect in the model and vice versa for the decreased population. We can, therefore, say that population growth is positively linked to the construction of new local roads.

These results support the findings of Cervero and Hansen (2002) and Levinson and Karamalaputi (2003) who also showed that population growth has a positive coefficient and is significant in inducing road investments in the United States. Our results are also in accordance 
with findings from previous studies (for instance, Aljoufie et al., 2013; Ji et al., 2014) that concluded that motorway development triggers urban growth within the vicinity of these motorways.

\section{Decision-making in local road projects}

The decision-making process is represented in the base model with technical and governance aspects. Technical aspects indicate the nature of the local road project, which can affect investment decision-making. The product of the spatial plan and the length of the project parameters is also to be positive (0.06). We can also hypothesise that local governments in Indonesia prioritise longer links construction that already included in the regional spatial plan. Using Norway case, Fridstrom and Elvik (1997) also observed that the lack of legal basis would reduce the odds of a project to be carried out. We also found that the government prefers to select expensive projects, indicated by the positive parameter of 'investment cost per kilometre' (0.05). Bigger projects are perceived to have larger accessibility benefits, as well as greater political interest (Eliasson et al., 2015).

Furthermore, a coefficient of 4.27 for the interaction between the variable 'new roads' and 'travel time' implies that local government is likely to invest in the construction of new roads that mainly aim to reduce travel time. It is in agreement with the finding from Nilsson (1991) that decision-makers prefer to consider the project's consequences, such as travel time reduction directly, to settle public sector investments.

The coefficient for 'urbanised areas' is negative (-5.43) in the composite model. It reflects that local government tends to invest in local roads located not in urban areas since it is already quite dense and connected enough or because land acquisition would be costly in such areas. This result is in line with several previous studies. For instance, Eliasson and Lundberg (2012) found that in Norway, the government's selection of road projects is skewed towards rural areas. Similarly, Fridstrom and Elvik (1997) obtained a negative coefficient for the variable 'major city area' in the selection of road projects.

Governance aspects of the decision-making process are represented in the models by the projects' main objective(s), the involvement of non-local government and the spatial plan variables (which indicate whether the project has been stated in the long-term spatial plan or not). In the composite model, we found that the involvement of the central and provincial government affects local road projects negatively (-8.31 and -8.82). This result is explained by the fact that that central government has to manage infrastructure development in the national level. Local roads are handled by local government on the municipal level. Involvement of upper-level government would indicate development of infrastructure to serve wider area and has a regional impact. The central government does occasionally invest in local roads, but it depends on the service area of the local roads and the benefits of a new link for regional developments. In such cases, the local governments have to submit a proposal to the central government.

\subsubsection{Arc Elasticities}

Given our findings, it is interesting to examine elasticities with respect to continuous variables that are significant in the composite model. The elasticity indicates the responsiveness in the probability of having a local road project if the value of one specific variable is increased by a certain unit. We calculated elasticity for several significant variables, namely the construction year gap (both positive and negative values) between the projects and toll gates, distance to toll gate, residential land use development, population change and investment cost per kilometre. 
Table 2.4 gives the absolute value of aggregate elasticities for the composite model for increments in specific variables of $1 \%, 5 \%, 10 \%$, while other variables remain constant. It also displays the relative changes in the average probability $(\bar{P})$, which express the changes in the probability in percentage terms. The elasticities can take on both positive and negative values. Positive elasticities indicate the increase in the probability given the increase in the modified variable, and vice versa. It is important to note that the relationship between the probability of having a local road with the parameters should not be perceived as entirely linear. Higher elasticities can occur across some ranges and lower across others.

The positive and negative variables of the construction year gap have the highest elasticities. Modifications of 'positive year gap' variable also produce the highest relative changes in the probability value. The negative elasticity of variable 'negative year gap' indicates the decrease in the probability given the increase in the value of this variable. These variables, then followed by 'distance toll gates' which its $1 \%$ increment resulted in a $0.11 \%$ increased in the probability to have a local road project.

Variable of 'residential land use development' has the smallest elasticity of all variables, which means that the probability of having a local road project is less sensitive to this variable. Furthermore, three variables that indicated population changes are more responsive than 'residential land use development', as a $1 \%$ increase in the population will increase the probability of having local road projects in the area by $0.08 \%$. Increasing population size corresponds to the increasing number of trips, and contributes to exhaustion of the existing road capacity, thus reducing the travel speed and total travel time. As Hansen and Huang (1997) and Cervero and Murakami (2010) also pointed out that population density is a major determinant of vehicle miles travelled in US cities.

Furthermore, the effect of project characteristics, such as investment cost cannot be ignored. The elasticity of 'investment cost' indicates that an increment of $1 \%$ in the cost per kilometre raises the probability of having a local road by $0.11 \%$. It is important to note that cost per kilometre does not consider the number of lanes, and local projects have fewer lanes than national or provincial projects. In addition, all projects in the database were funded, therefore the present model forecasts the probabilities of being funded as a local or national project.

Table 2.4. Average Arc Elasticities

\begin{tabular}{|l|l|l|c|c|c|c|c|c|}
\hline & & & \multicolumn{2}{|l|}{$1 \%$ Change } & $5 \%$ Change & \multicolumn{2}{|c|}{$10 \%$ Change } \\
\cline { 4 - 9 } $\begin{array}{l}\text { Modified } \\
\text { variable }\end{array}$ & Mean & Unit & $\bar{E}$ & $\begin{array}{l}\text { Relative } \\
\text { change } \\
\text { of } \bar{P}\end{array}$ & $\bar{E}$ & $\begin{array}{l}\text { Relative } \\
\text { change } \\
\text { of } \bar{P}\end{array}$ & $\bar{E}$ & $\begin{array}{l}\text { Relative } \\
\text { change } \\
\text { of } \bar{P}\end{array}$ \\
\hline $\begin{array}{l}\text { Positive year } \\
\text { gap }\end{array}$ & 13.22 & Year & 0.343 & $0.07 \%$ & 0.358 & $0.35 \%$ & 0.377 & $0.71 \%$ \\
\hline $\begin{array}{l}\text { Negative year } \\
\text { gap }\end{array}$ & 0.37 & Year & -0.266 & $-0.01 \%$ & -0.199 & $-0.03 \%$ & -0.146 & $-0.06 \%$ \\
\hline $\begin{array}{l}\text { Distance to } \\
\text { toll gate }\end{array}$ & 4.04 & Km & 0.113 & $0.02 \%$ & 0.115 & $0.11 \%$ & 0.118 & $0.22 \%$ \\
\hline $\begin{array}{l}\text { Residential } \\
\text { land use } \\
\text { development }\end{array}$ & 0.85 & Ha & 0.013 & $0.00 \%$ & 0.013 & $0.01 \%$ & 0.013 & $0.03 \%$ \\
\hline
\end{tabular}




\begin{tabular}{|c|c|c|c|c|c|c|c|c|}
\hline \multirow[b]{2}{*}{$\begin{array}{l}\text { Modified } \\
\text { variable }\end{array}$} & \multirow[b]{2}{*}{ Mean } & \multirow[b]{2}{*}{ Unit } & \multicolumn{2}{|c|}{$1 \%$ Change } & \multicolumn{2}{|c|}{$5 \%$ Change } & \multicolumn{2}{|c|}{$10 \%$ Change } \\
\hline & & & $\bar{E}$ & $\begin{array}{l}\text { Relative } \\
\text { change } \\
\text { of } \bar{P}\end{array}$ & $\bar{E}$ & $\begin{array}{l}\text { Relative } \\
\text { change } \\
\text { of } \bar{P}\end{array}$ & $\bar{E}$ & $\begin{array}{l}\text { Relative } \\
\text { change } \\
\text { of } \bar{P}\end{array}$ \\
\hline $\begin{array}{l}\text { Population } \\
\text { change } \\
(2010-2015)\end{array}$ & 7.28 & Person & 0.078 & $0.01 \%$ & 0.079 & $0.07 \%$ & 0.080 & $0.14 \%$ \\
\hline $\begin{array}{l}\text { Population } \\
\text { increased } \\
(2000-2010) \\
\end{array}$ & 45.00 & Person & 0.046 & $0.01 \%$ & 0.047 & $0.04 \%$ & 0.047 & $0.08 \%$ \\
\hline $\begin{array}{l}\text { Population } \\
\text { decreased } \\
(2000-2010)\end{array}$ & -2.04 & Person & -0.017 & $0.00 \%$ & -0.017 & $-0.01 \%$ & -0.017 & $-0.03 \%$ \\
\hline $\begin{array}{l}\text { Investment } \\
\text { cost per } \\
\text { kilometre }\end{array}$ & 16.47 & $\begin{array}{l}\text { Billion } \\
\text { IDR }\end{array}$ & 0.107 & $0.02 \%$ & 0.109 & $0.11 \%$ & 0.112 & $0.22 \%$ \\
\hline
\end{tabular}

\subsection{Conclusions}

This study examined the direct and indirect effects of toll road construction on local road projects in the Jakarta-Bandung region. The main contribution of this study is the use of high temporal and spatial resolution to analyse ex-post toll case in developing countries, as well as combining statistical analysis, with spatially detailed data to perform a robust predictive model.

Our modelling results firstly show that existing and planned toll roads induce the development of local road projects both directly and indirectly. Local road projects tend to be developed in anticipation of the opening of the toll road, and advocated by local governments to reduce travel time. The changes in residential area and population around the toll roads also induce local road construction. This finding strengthens the argument that it is necessary to separate direct and indirect effects of major road investments.

Secondly, with regard to methodology, we conclude that the models exhibit a reasonable explanatory power and that the direct effect model has a better goodness of fit than the indirect effect model. The addition of parameters related to toll roads and urban development, such as project and toll gate year gap, distance to toll gate, residential land use and population changes significantly improved the basic model to describe the decision-making of local road project constructions.

Finally, there are policy and planning implications that can be derived from this study. We have shown that toll road construction in the Jakarta and Bandung region affects local road investment, both directly and indirectly, through the changes in residential area and population. Economic appraisals of major transport investments in Indonesia and elsewhere might take into account induced demand effects but do not account for induced supply effects on local infrastructure. However, induced supply effects can influence traffic flows, accessibility levels and thus the economic and social impacts of major road investments.

In the Indonesian decentralised government system, local government has the full authority to carry out local road projects. They, thus, should synchronise local road plans with the national road plan and anticipate any effects due to the construction of major national roads, such as the emerging of new activities and the increasing number of population. The central government could consider induced supply effects in economic appraisals of toll roads by conducting some sensitivity analysis. 
Future research can improve these analyses by incorporating local road projects in a wider area (beyond the 18-km zone used in this study). In addition, our data do not enable us to determine which projects will be realised and which ones will not, since our study only concerns road projects that had already been approved by the local government. There may be other factors, such as network-related variables (congestion, road capacity and current travel speed), as well as political agenda or national events that play a role in decision-making, but that are not part of our dataset and therefore were not captured by our models.

Furthermore, to be able to identify the indirect effect of toll road construction, it is essential to have reliable time series. For instance, the intervals of land use and population data should be consistent and small enough to be able to test the effect of different time periods on transport investment and vice versa. This might reveals feedback relationships between road transport investment and land use changes that are not incorporated in our study. 


\title{
3. Job accessibility and spatial equity impacts
}

This chapter is based on: Andani, I.G.A., La Paix Puello, L., Rachmat, S., Syabri, I., Geurs, $\mathrm{K}$ (2019). An ex-post evaluation of the job accessibility and spatial equity impacts of a toll road in the Jakarta - Bandung region, Indonesia. Submitted for publication in Journal of Transport Geography.

\begin{abstract}
This chapter describes an ex-post evaluation of the job accessibility and spatial equity impacts of the Cipularang toll road in the Jakarta - Bandung corridor in Indonesia, which was constructed in 2005. An ArcGIS transportation demand model extension was used to obtain travel time and generalised cost estimates. The potential accessibility measure and Shen accessibility index were used to measure accessibility with and without job competition. Spatial equity was examined based on the accessibility measures using the Gini coefficient, Palma ratio and a two-step cluster analysis. The analysis shows that the construction of the Cipularang toll road has reduced travel in the whole region by $13 \%$ and potential job accessibility increased by $5 \%$. However, the toll road also increases job competition as more workers can access jobs available in the job-poor area in between Jakarta and Bandung, resulting in a small decrease in the amount of accessible jobs per worker. Furthermore, we found that the construction of the toll road has no impact on spatial equity as measured by the Gini coefficient and Palma ratio.
\end{abstract}

Keywords: accessibility, equity, employment, toll road 


\subsection{Introduction}

Accessibility, defined as the number of activities that can be reached within a certain area (Dalvi \& Martin, 1976), is often used in transport equity analysis. While its emphasis is on people and their interactions with places, it also captures transportation infrastructure and the spatial structure of the destinations (land use) (Geurs \& van Wee, 2004). Accessibility of opportunities, such as jobs, is one of the main elements of transportation equity (Cheng \& Bertolini, 2013; Grengs, 2012; Wang \& Chen, 2015).

Several ex-post evaluations have been conducted on the accessibility impacts of motorway developments in Europe for periods of twenty years and longer, e.g. by Holl (2007) and by Axhausen et al. (2011). Both these studies found that with motorway construction, the accessibility gains shift the focus away from central cities to peripheral areas. However, a new road can have diverse equity impacts, ranging from people's social opportunities to access regional economic developments.

A particular example is the construction of a new toll road, requiring users to pay if they wish to use it. In several countries, toll charges are a way to cope with difficulties in financing new infrastructure (Odeck \& Bråthen, 2008; Ramjerdi, 2006). This allows users a trade-off between a quicker but expensive route and a slower but inexpensive route. The additional costs and changes in travel time can be unevenly distributed across a population, according to socioeconomic level. There can even be groups for which the new road has detrimental effects. For example, van Dijk et al. (2015) showed that high-income commuters are more likely to benefit from toll roads, whereas lower-income commuters choose alternative non-tolled routes.

This study aims to gain a better understanding of how the benefits of a new major toll road are distributed over the adjacent areas. We present an ex-post evaluation of the impact of a toll road on job accessibility and spatial equity in a developing country context, which to our knowledge has not been done before. So far, the few studies of the impacts of toll roads described in the literature have been ex-ante studies, such as by van Dijk et al. (2015), who conducted a GISbased evaluation of traffic and job accessibility impacts of planned toll roads in Cape Town, South Africa. We used an ArcGIS transportation demand model extension to estimate the transport impacts of the introduction of the Cipularang toll road in the Jakarta - Bandung corridor in Indonesia. We calculated several accessibility measures to distinguish the effects on jobs and working population distribution. The Gini coefficient, Palma ratio and a two-step cluster method were applied to gain insight into the distribution of the impacts on job accessibility across the region. In this study, we extended the work by Pritchard, Tomasiello, Giannoti, and Geurs (2019) through the use of a traffic simulation model with congestion effects to estimate travel time between districts. To arrive at more accurate estimates, we took the stated choice-based value of time into account in the model.

The Cipularang toll road links two major Indonesian cities, Jakarta and Bandung. In 2004, 78.3 million passengers passed through the Jakarta - Bandung corridor, making it one of the busiest passenger transportation routes in Indonesia. The distance between the cities is about $180 \mathrm{~km}$ and the modal split has been dominated by car, at 95.8\% (Lubis et al., 2005). Empirical evidence also suggests that the introduction of this toll road corridor induced positive responses from the real estate market (Dorodjatoen, 2009). In the Indonesian context, ex-post evaluation of transport infrastructure investments has not yet received much attention.

This chapter is structured as follows. After this introduction, Section 3.2 describes how we measured accessibility and equity. Section 3.3 sets out the methodology and data that we employed in this study. Section 3.4 explains the study area. We discuss the results of the 
simulation and accessibility measurements in Section 3.5. Lastly, Section 3.6 concludes this chapter with a summary, recommendations and suggestions for future research.

\subsection{Measuring accessibility and spatial equity}

\subsubsection{Accessibility measures}

Accessibility, first defined by Hansen (1959) as the potential of opportunities for interaction. There are many definitions afterwards. Among others, Dalvi and Martin (1976) described accessibility as the ease of reaching any activity using the available transport system. On the basis of a large number of studies, Geurs and van Wee (2004) were able to distinguish four main elements to define accessibility: transport, land use, temporal and individual components. These elements can influence each other. For example, a land use component, such as the spatial distribution of activities, can determine the travel demand and if hampered by the infrastructure (e.g. road capacity, maximum speed, public transport timetables), will produce transport resistance, expressed as travel time or cost. Activities can be restricted by time, e.g. store opening hours (temporal component). The individual components can also interact with all other components, related to the ability and needs of individuals to travel, in turn, linked to factors such as their income, age and level of education.

Accessibility measures can be categorised by the following four types: (1) infrastructure-based accessibility, (2) location-based accessibility, (3) person-based accessibility and (4) utilitybased (Geurs \& van Wee, 2004). Infrastructure-based accessibility approaches can involve, for instance, supply-oriented measures (e.g. distance to nearest toll gate) or demand-and-supplyoriented measures (e.g. actual travel times) (van Wee, Hagoort, \& Annema, 2001). Moreover, location-based accessibility approaches, for instance, estimate the number of opportunities reached within a given travel time or distance (i.e. cumulative opportunities) or number of opportunities at destinations that can be reached from an origin location, weighted by a distance decay (i.e. potential or gravity-based measure).

Comparisons of these measures can be found in the works of Kwan (1998) and Neutens, Schwanen, Witlox, and De Maeyer (2010). When comparing location-based and person-based measures, they concluded that location-based measures are highly correlated and that the latter approach has better explanatory power as they are able to explain the characteristics of individual travel behaviour as well. However, person-based measures have important drawbacks related to data availability and complexity and are more suitable for relatively small regions or subsets of a population.

In this study, we applied infrastructure-based measures to assess the performance of the road network as well as location-based measures. The infrastructure-based measure focuses on the performance or service level of transport infrastructure, such as the length of infrastructure networks, level of congestion and average travel speed on the road network. It is worth noting that estimating travel time without considering capacity restraints and traffic flow will result in underestimation. Hence, several researchers also developed a traffic model to evaluate road infrastructure investment (e.g. van Dijk et al., 2015; Xiong et al., 2015).

Furthermore, location-based measures are associated with land use and location, and typically assess the level of accessibility to spatially distributed activities, such as jobs, public facilities or people. Potential accessibility or gravity measure is commonly used in this approach. Potential accessibility is calculated by weighting opportunities in a certain area by using an attribute of attraction (population, facilities, etc.) and a measure of impedance (distance, travel 
time, cost). More complex location-based measures also include competition effects by incorporating capacity restrictions of supplied activity characteristics (e.g. Cheng \& Bertolini, 2013; Geurs \& van Eck, 2003). Thus, we evaluated the combined effects of transport elements and job distribution, augmented by the inclusion of congestion and competition effects.

\subsubsection{Equity evaluation}

Equity is defined as the distribution of impacts (benefits and costs) and whether that distribution is considered fair and appropriate. (Litman, 2015). There are many types of equity, depending on the objective and focus of the analysis. It can be differentiated into horizontal, vertical, spatial or social equity (see Litman, 2015; Wee \& Geurs, 2011). Over the past few decades, equity aspect of accessibility has gained more attention as a framework to evaluate the impact of new transport infrastructure (e.g. Bocarejo et al., 2014; Fan et al., 2010). Several authors have discussed how to measure accessibility by using social justice principles (e.g. Golub \& Martens, 2014; Lucas, van Wee, \& Maat, 2016). However, we did not focus on social justice principles and the theoretical perspectives of equity, but on the distribution of accessibility impacts across the region, assessing which area is affected most by the new toll road.

Several indicators can be used to assess the equity impacts of accessibility. Ramjerdi (2006) conducted a comprehensive study by comparing various inequity measures to assess the impact of road pricing policy. The author concluded that using a single measure can lead to a biased evaluation. She also pointed out that the Gini coefficient (Gini, 1936), which has been widely used to assess income inequity, is insensitive to any changes in measurement (scaleindependent), which gives it a major advantage over other measures. Nevertheless, its usefulness still depends on the choice of accessibility measures (Lucas et al., 2016). The Gini coefficient also has been adopted to evaluate distributional impacts of accessibility in some studies (e.g.in Lucas et al., 2016; Pritchard et al., 2019; Wee \& Geurs, 2011).

Complementary to the Gini index, we also explored the Palma ratio (Palma, 2011), which is rarely used in transportation research. Originally, the Palma ratio depicts the ratio of income shares between the richest $10 \%$ and the poorest $40 \%$, as Palma had found that the middleincome group generally accounts for half of the national income, and has a relatively stable share over time (Banister, 2018; Guzman \& Oviedo, 2018). We expected these equity and accessibility measures to provide insights into the distribution of welfare over the Jakarta Bandung region.

\subsection{Methods and data}

To assess the impact of the Cipularang toll road on accessibility and spatial equity, we applied three stages of analysis in this study. Firstly, we created an ArcGIS transport network and the four-step transport model extension Traffic Analyst for ArcGIS (Rapidis, 2018) ${ }^{1}$ was used to produce traffic flows, travel time and generalised cost matrices in a scenario with and without the toll road. Next, we developed a 24-hour traffic simulation, which included the toll road. The use of the transport demand model enabled us to consider congestion effects by adding capacity restraints in the traffic model. We employed road network data from OSM (OpenStreetMap contributors, 2016) as it provided road network data up to local level. Applying four-step model is challenging because of data limitations. It is important to note as well that our model aimed

\footnotetext{
${ }^{1}$ We thank Rapidis for providing the license and assistance for working with Traffic Analyst.
} 
to predict travel times in the Jakarta-Bandung region and, specifically, traffic flow on the corridor of the Cipularang toll road, thus we ignored traffic on other roads. Secondly, we calculated accessibility indicators by using the generated travel time and cost matrices, taking into account the number of jobs and the size of the working population. Thirdly, we conducted a spatial equity analysis on the basis of the equity indices (Gini coefficient and Palma ratio) and spatial distribution of accessibility with a two-step cluster method.

\subsubsection{Traffic simulation}

\section{Traffic flow modelling}

The traffic simulation was conducted through the conventional four-step model. Firstly, a number of trips were generated in each district by considering the population size and the proportion of residential area as production parameters and the number of jobs and the proportion of industrial and commercial areas as attraction parameters. The parameters were estimated from a regression analysis using SITRAMP 2004 data from the Jakarta metropolitan area (JICA and BAPPENAS, 2004).

In the second phase, the balanced-generated trips were distributed using Furness method. This method also used a deterrence function, which was calculated from the gravity parameter and road traffic cost matrix. The gravity parameter assumes that a higher travel time will result in fewer trips made. We calculated it from the Indonesian labour force travel survey that mapped the mobility of labour forces in the study area in 2015 (BPS, 2015). Furthermore, road traffic cost was calculated from generalised cost considering the travel time between districts (Google Maps API data ${ }^{2}$ ), fuel cost for each type of vehicle and value of time. The value of time was derived from a stated-choice experiment conducted in the Jakarta-Bandung region for 1,600 respondents (Chapter 5 explains more details about this experiment). Next, a growth factor forecasting calculation (Furness method) was performed on the balanced generated trips and converted into an origin-destination (OD) matrix.

In the third phase, OD matrices for three modes were estimated (car, heavy vehicle and motorcycle), using the proportion of mode share in the area. Lastly, road traffic assignment was carried out, assigning the generated OD matrix to the road network. A user equilibrium algorithm was used in this assignment. This last step produces the best travel route, the amount of traffic and the costs (travel time, distance and generalised cost) for the pair of zones.

\section{Model validation}

The model was validated by using observed travel time by car, retrieved from Google Maps API data. We calculated the root mean square percentage error (RMSPE) and correlation coefficient to measure the difference between estimated and observed travel time.

\subsubsection{Accessibility measurements}

As mentioned, we calculated several accessibility measures for the two scenarios (with and without Cipularang toll road). Those measures are average travel time, average generalised costs, contour accessibility of jobs and potential accessibility.

\footnotetext{
${ }^{2}$ Observed travel time data for 2018 during peak hours on Monday at 7.00 in the morning
} 


\section{Average travel time and generalised cost}

Average travel time and generalised cost $\left(\overline{C_{r}}\right)$ were calculated by summing up the travel time or generalised costs for all the trips from one origin $(i)$ in situations with the Cipularang toll road $(r=1)$ and without it $(r=0)$, and then dividing this by the total amount of trips possible $(n)$ from that origin.

$$
\overline{C_{r}}=\frac{\sum_{i} C_{i r}}{n_{C_{i r}}}
$$

The monetary cost in the link was determined from the generalised cost, taking into account fuel cost and value of time $(\text { VoT })^{3}$.

The generalised cost in link $i\left(g c_{i}\right)$ was calculated using the following formula:

$$
g c_{i}=f c_{i} d_{i}+t c_{i} d_{i}+t t_{i} V o T
$$

where $f c_{i}$ is fuel cost (IDR per kilometre), $d_{i}$ is length of the link (in kilometre), $t c_{i}$ is toll cost (IDR per kilometre), $t t_{i}$ is travel time (hour), and $V o T$ is value of time (IDR per hour).

\section{Potential job accessibility}

Job accessibility denotes the ease that spatially distributed jobs can be reached from a given location. The most commonly used potential accessibility measure is based on Hansen's accessibility formula (Hansen, 1959), as follows:

$$
S_{i r}=\sum_{j} E_{j} f\left(d_{i j r}\right)
$$

Here, $S_{i}$ is the accessibility for location $i$ with toll road $(r=1)$ or without $(r=0), E_{j}$ is the number of relevant jobs in location $j, d_{i j r}$ is distance (travel length, time or cost) of a trip from $i$ to $j$ with toll road $(r=1)$ or without $(r=0)$, and $f\left(d_{i j r}\right)$ is the distance decay function measuring the spatial separation between locations $i$ and $j$.

The distance decay function reflects the friction in connecting zones $i$ and $j$ in the network, and is negatively correlated with the attractiveness of the destination (i.e. jobs). The accessibility results, therefore, are profoundly affected by the decay function. Various types of distance decay were tested for the accessibility analysis (see the comparison in Table 3.1 and Figure 3.1), such as negative power (e.g. Hansen, 1959; Kotavaara, Antikainen, \& Rusanen, 2011), negative exponential (e.g. Cheng \& Bertolini, 2013; Neutens et al., 2010; Stepniak \& Rosik, 2013), logistics (e.g. Geurs \& van Eck, 2003) or Gaussian (e.g. Ingram, 1971; Luo \& Qi, 2009). However, as discussed by Geurs and Ritsema van Eck (2001) and Ingram (1971), negative power and exponential functions decay too rapidly and are somewhat sensitive to short distances. Power function is not depicted in Figure 3.1 as the probability value is too low.

\footnotetext{
${ }^{3}$ Value of time was determined from the cost and time parameters estimation using data of the aforementioned household survey
} 
Table 3.1. Goodness of fit $\left(\mathbf{R}^{2}\right)$ of fitted distribution functions

\begin{tabular}{|l|l|l|l|l|}
\hline \multirow{2}{*}{\multicolumn{1}{|c|}{ Impedance }} & \multicolumn{3}{|c|}{ Distribution function } \\
\cline { 2 - 5 } & \multicolumn{1}{|c|}{ Log-logistic } & Gaussian & $\begin{array}{c}\text { Negative } \\
\text { exponential }\end{array}$ & Power \\
\hline Time & 1.00 & 0.99 & 0.99 & 0.86 \\
\hline Generalised cost & 1.00 & 1.00 & 0.97 & 0.77 \\
\hline
\end{tabular}

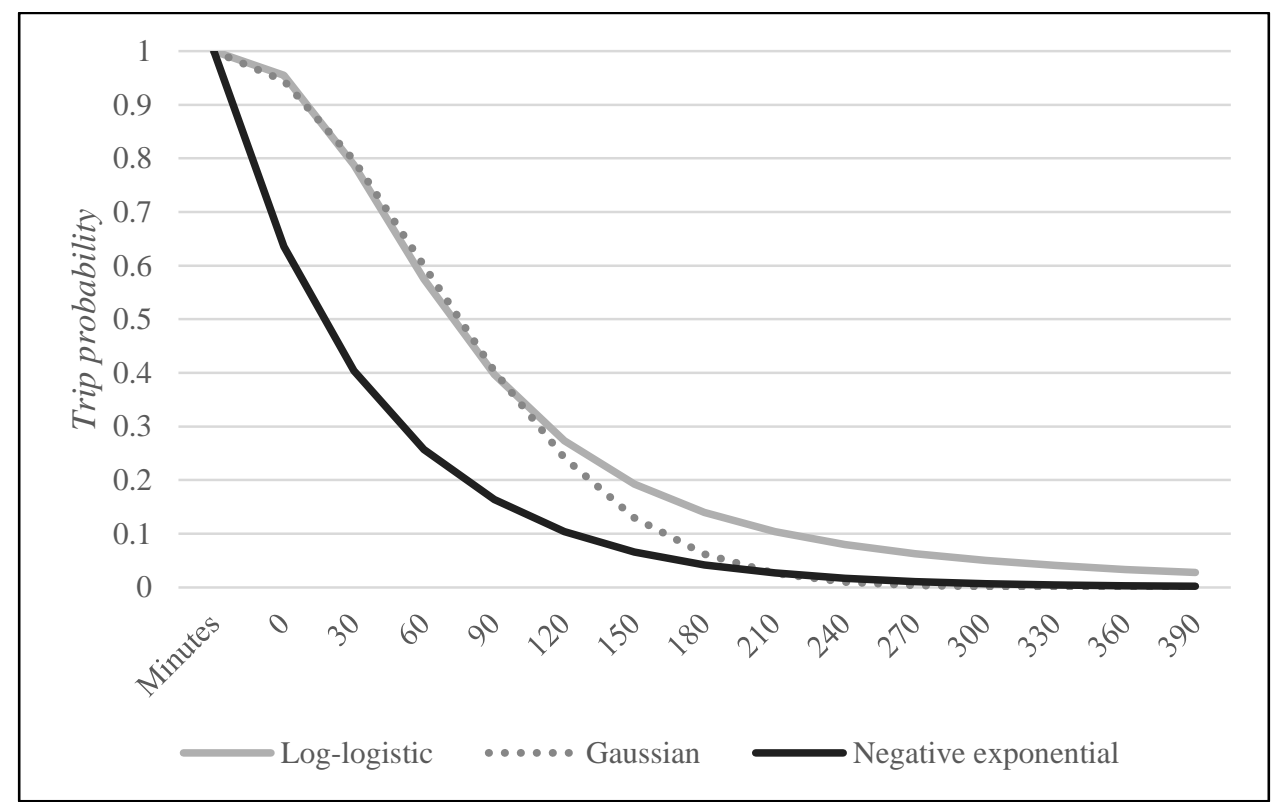

Figure 3.1. Fitted distribution functions

Regarding the impedance parameter based on the household survey data, we found that the loglogistic distance decay function produced the best fit with the travel data:

$$
f\left(d_{i j}\right)=\left(1+\exp \left(a+b \ln d_{i j}\right)\right)^{-1}
$$

where $a$ and $b$ are parameters to be estimated. We estimated the parameters of separate loglogistic functions for both time and generalised cost (Table 3.2).

Table 3.2. Parameters for log-logistic distance-decay function

\begin{tabular}{|l|l|l|}
\hline Impedance & $a$ & $b$ \\
\hline Travel time & -11.55 & 2.50 \\
\hline Generalised cost & -11.71 & 2.10 \\
\hline
\end{tabular}

\section{Potential job accessibility with impedance function and competition (Shen index)}

To improve these accessibility measures, we considered competition in the accessibility measurement by including the potential demand for jobs. Potential job accessibility measures the number of jobs within reach of a resident from an origin within a certain travel distance (potential demand) divided by the potential number of residents within reach of the same 
destination (Shen, 1998). In this study, we refer to this accessibility measure as the 'Shen index.' If the Shen index is one, then the number of jobs is proportional to the size of the working population. It can be calculated with the following formula:

$$
A_{i r}=\sum_{j} \frac{E_{j} f\left(C_{i j r}\right)}{D_{j}}, \quad D_{j r}=\sum_{k} L_{k} f\left(C_{k j r}\right)
$$

Here, $A_{i}$ is the jobs accessibility of people living in location $i$, with toll $\operatorname{road}(r=1)$ or without $(r=0), E_{j}$ is the number of relevant jobs in location $j, D_{j}$ is the number of people seeking job opportunities in location $j, L_{k}$ is the number of working population in study area, and $f\left(C_{k j r}\right)$ is the impedance function measure the spatial separation between $k$ and $j$, with toll road $(r=1)$ or without $(r=0)$.

The data used to calculate job accessibility in this study was collected from the Indonesian database for policy and economic research (INDO-DAPOER) ${ }^{4}$. We used employment data as proxy for the number of jobs in the study area and defined employed people as persons who worked for pay or assisted others in obtaining pay or profit for the duration at least one hour during the survey week. As pointed out by the Asian Development Bank and BPS (2010), a job can be described as any productive activity carried out by an employed person. Within this approach, informal jobs can also be taken into account. Informal jobs were measured in this dataset as those assigned to individuals who were self-employed, family or unpaid workers. A more appropriate way to assess job availability is to focus on firms instead of workers (Rothenberg et al., 2016). However, this was not possible in this study owing to data limitations.

In addition, we used labour force data to calculate the number of jobseekers in the study area. In this context, 'labour force' was defined as persons 15 years old and older who were working, were temporarily absent from work but had jobs, or who did not have work and were looking for work (BPS, 2015). That way, we excluded people of working age who were in schools, doing housekeeping, or not doing or looking for any profitable activity. This data was only available for the municipal level; to be able to conduct analyses at the district level, this data was extrapolated by using the population ratio.

\subsubsection{Measuring spatial equity}

In addition to the impact of the new toll road on job accessibility, we also wanted to evaluate its impact on spatial equity, i.e. its overall distribution, inequity at the extreme groups and whether job accessibility is distributed evenly across the region. To that end, we measured the Gini coefficient, Palma ratio, and the spatial distribution of accessibility with a two-step cluster method.

The Gini coefficient (Gini, 1936) is commonly used to measure the distribution of income. It is a value between 0 and 1, where 0 is perfect equity and 1 is perfect inequity. We calculated the Gini coefficient to compare accessibility levels with and without the toll road. We estimated

\footnotetext{
${ }^{4}$ Indonesia Database for Policy and Economic Research (INDO-DAPOER) is managed by The World Bank and retrieves datasets from BPS-Statistics Indonesia, available from http://databank.worldbank.org/data/reports.aspx?source $=1266$.
} 
the coefficient by using the trapezoidal Lorenz curve approximation, depicting the (ranked) cumulative share of accessibility against the cumulative share of the corresponding population by district across the Jakarta - Bandung region. A Gini coefficient of 0.5 says that there is high inequality, but says nothing about the distribution of that inequality (Banister, 2018).

Rather than focus on the overall distribution, the Palma ratio emphasizes the magnitude of the gap between the rich and the poor. It is a ratio, namely of the richest $10 \%$ population's share of gross national income divided by the share of the poorest $40 \%$ (Palma, 2011). In this study, we adopted the work of Guzman and Oviedo (2018) and Pritchard et al. (2019) by calculating the Palma ratio to assess the inequity between the average accessibility of the richest $10 \%$ districts and the poorest $40 \%$ districts. A Palma ratio of 2.0 indicates that the top $10 \%$ (in terms of income) has twice the (job) accessibility level as the lowest $40 \%$.

To account for spatial distribution of the job accessibility, we clustered job accessibility measures and districts in the study area by using a two-step cluster method in which the number of clusters was determined on the basis of the minimum value of the Bayesian information criterion - BIC ${ }^{5}$ (Schwarz, 1978). Cluster analysis is commonly used in transport and land use domain studies to create groups of areas with homogenous accessibility measures and land use characteristics (e.g. Verhetsel \& Vanelslander, 2010; Wang, Han, \& de Vries, 2018). This method enabled us to identify the characteristics of districts that are likely to benefit from the new toll road and classify them based on the accessibility impacts.

Several variables were also included to identify the characteristics of districts most likely to benefit from the new toll road and classify them based on accessibility impacts. According to Chi (2012), the impact of a new highway differs across rural, suburban and urban areas. The implementation of a new toll affects different income population segments differently (Di Ciommo \& Lucas, 2014; van Dijk et al., 2015). Therefore, in the cluster analysis, we considered variables of residential land use growth and income per capita to classify the districts. However, since income data was not available for the district level, we used monthly expenditure instead (see the deciles of distribution in Figure 3.4). Monthly expenditure is highly correlated with income data at the provincial level (a correlation of 0.86, see Figure 3.2) and, therefore, was a good proxy for income in this study. Furthermore, as the main focus of this study, the distribution of jobs and the working population were also included in the cluster analysis.

\subsection{Study area}

The study area covers approximately $15,250 \mathrm{~km}^{2}$ in the corridor between Jakarta and Bandung as shown in Figure 3.3. The name 'Cipularang' is a contraction of 'Cikampek, Purwakarta and Padalarang.' This toll road connects Jakarta and Bandung by connecting the Jakarta-Cikampek toll road and the Padalarang-Cileunyi (Padaleunyi) toll road (of which the Pasteur toll road in Bandung is also a part). The Cipularang toll road has five gates; three gates are located in the West Bandung Regency, and the other two are in the Purwakarta Regency. Between 2004 and 2013, residential land use increased by $2.5 \%$ and industrial land use by $1 \%$ (Andani, La Paix Puello, \& Geurs, 2019). The emergence of industrial and residential areas contributed to the increasing accessibility, although jobs as well as the working population still concentrated in the Jakarta and Bandung metropolitan area, as shown in Figure 3.4.

\footnotetext{
${ }^{5}$ Also called Schwarz Criterion, is a criterion for model selection among a finite set of models. The lowest value is preferred.
} 


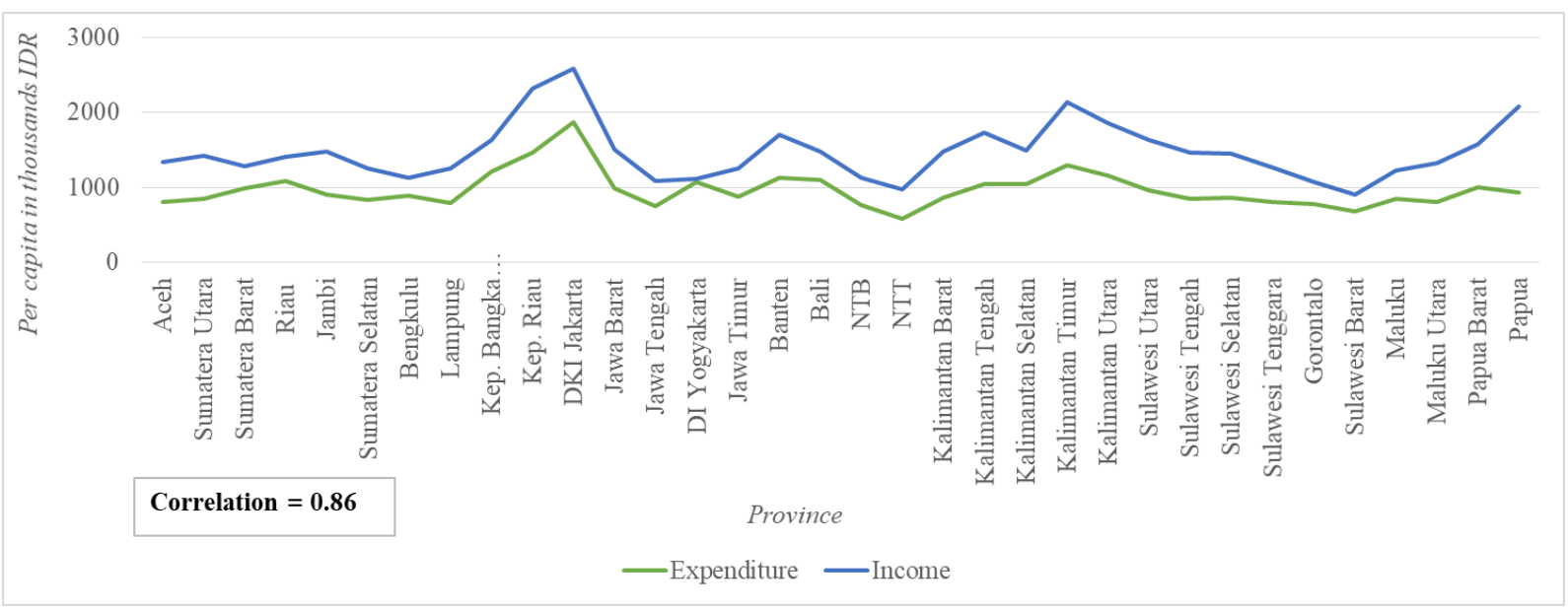

Figure 3.2. Correlation between monthly expenditure and income per province

Source: BPS (2017b, 2018)

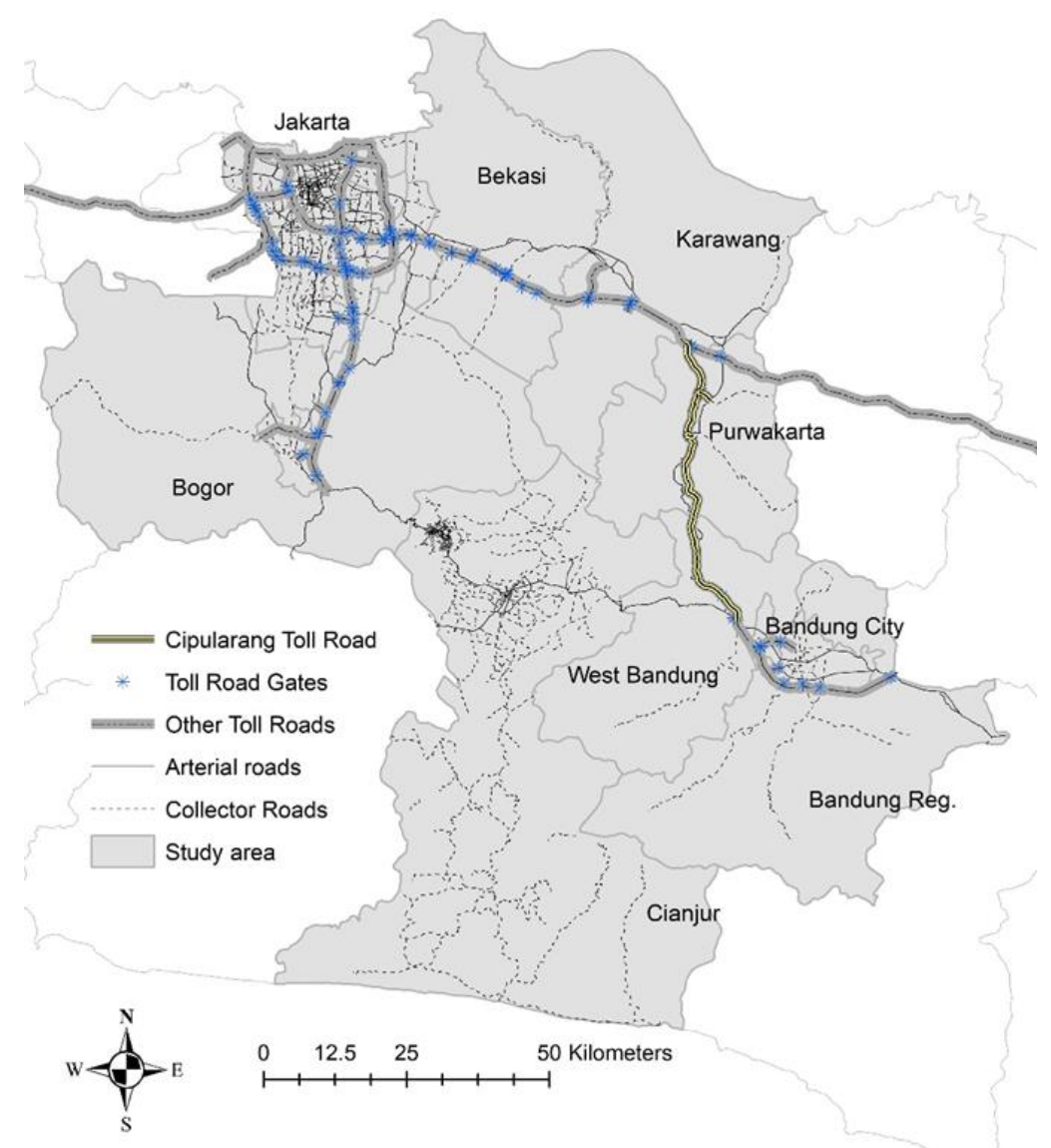

Figure 3.3. Overview of the study area 


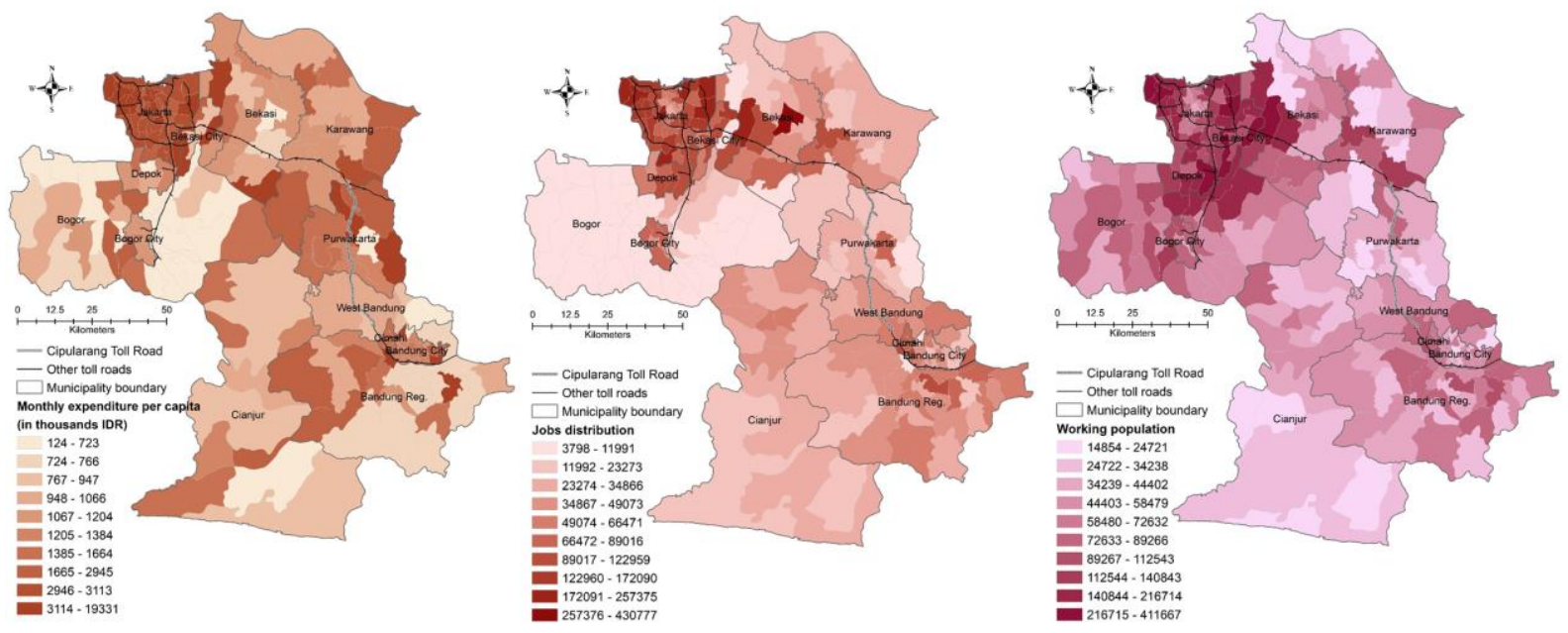

Figure 3.4. Spatial distribution of monthly expenditure per capita (left), jobs (centre) and working population (right)

\subsection{Results and discussion}

This section presents the results of the traffic simulation (average travel time and generalised cost), for potential job accessibility and the spatial distribution of these values across the region.

\subsubsection{Travel time estimation}

Several performance measures were applied to evaluate the accuracy of the match between the observed travel time, derived from the Google Maps API, and simulated travel time. The value of the RMSPE is $9.7 \%$, and the value of the correlation coefficient is 0.90 . This indicates that the error is small enough and the accuracy of the model high enough to be able to predict travel time between origin-destination pairs. As Figure 3.5 shows, the model results show a similar pattern as the observed travel times. The estimated traffic flows on the Cipularang toll road are in line with the observed traffic data, with a percentage error of 3.7\%. Figure 3.6 shows that without the Cipularang toll road, there is less traffic in Bandung and the northern part of this region. On the other hand, there is a significant increase in traffic on the other regional nontolled roads.

Average travel time between districts was estimated to be 154 minutes, similar to the observed travel time obtained from Google Maps API (155 minutes). The most strongly impacted regions are in the corridor including the northwestern area in Jakarta and the southeastern region in Bandung (see Figure 3.7).

Regions in the west, such as Bogor and Cianjur, appear to be least affected by the development of Cipularang toll road. Overall, weighted by the traffic flow, the Cipularang toll road has reduced the average travel time in the whole region by 13\%; see Table 3.3. Several districts in Purwakarta experienced a weighted average travel time reduction up to $25 \%$. This can be explained by the fact that this area contains two toll gates. It is also situated between two employment centres in the area: Jakarta and Bandung. This finding supports the work by van Dijk et al. (2015) that impact of toll is mostly occurred in the area alongside the toll road. 


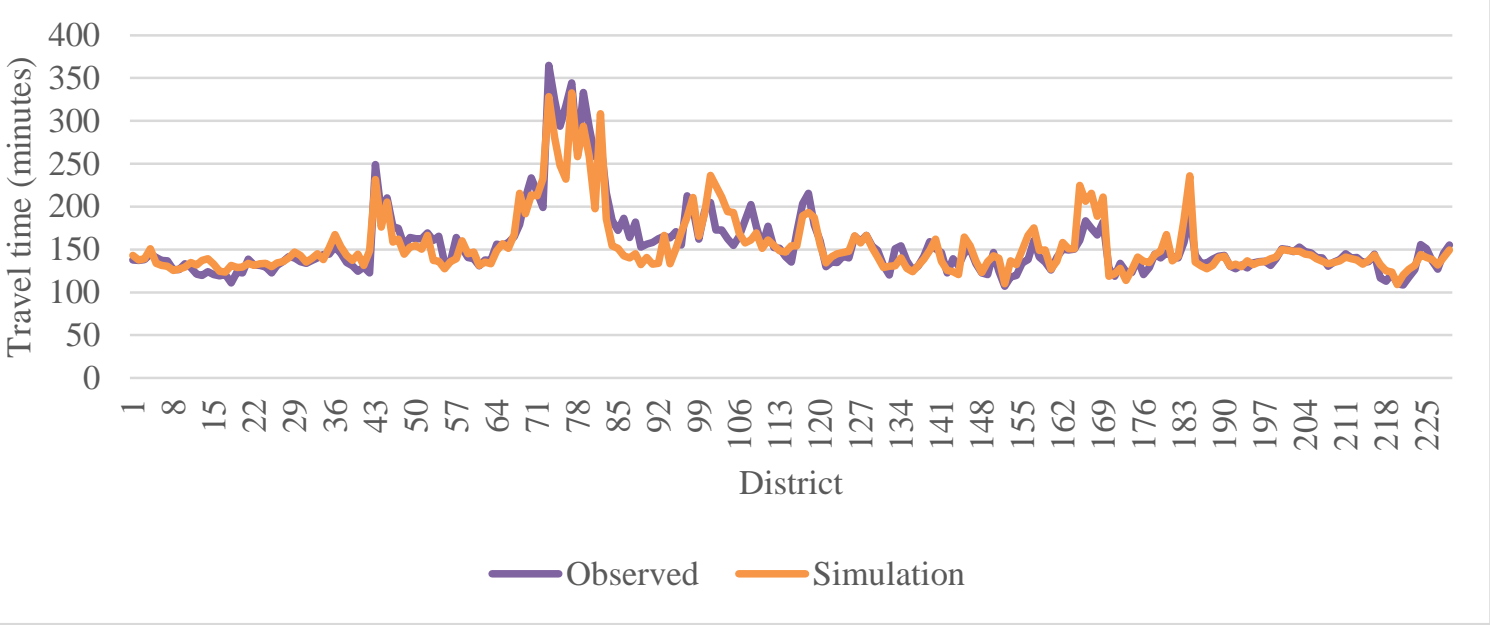

Figure 3.5. Comparison between observed and model results

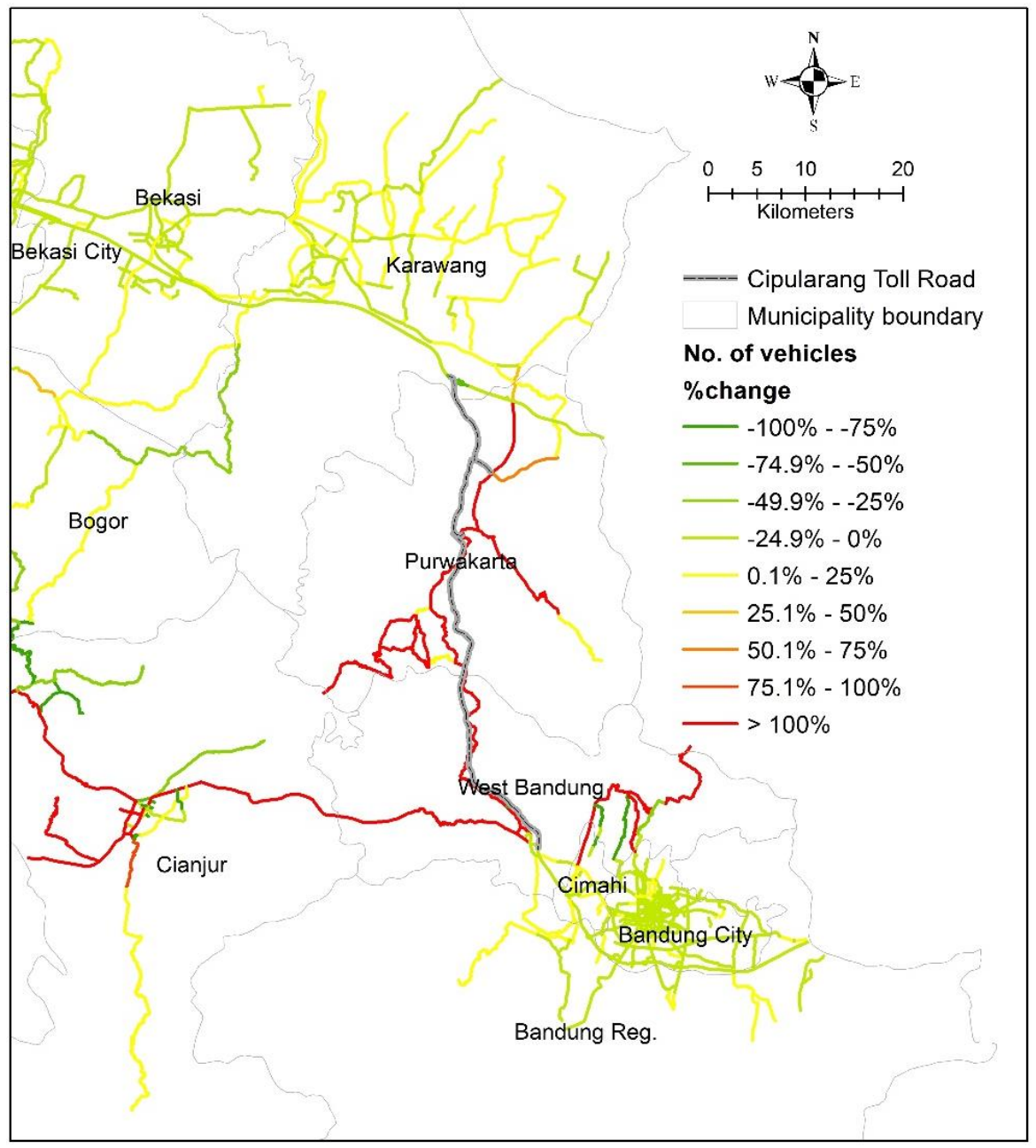

Figure 3.6. Changes in traffic flows without the Cipularang toll road 
When we looked at specific origin-destination pairs, we found that the greatest reduction in travel time occurred between Cipendeuy (a district in the Bandung regency) and Teluk Jambe (a district in Karawang), which had almost 1.5 times greater travel times without the Cipularang toll road. The difference between the estimated average generalised cost with and without the toll road is not as great as the difference for the average travel time, given that to use the toll road, users need to pay a fee, which increases the total travel cost (see statistics in Table 3.3). As observed from Figure 3.7, average travel time and generalised cost show a contrast between areas in the toll road corridor and areas at great distances from it.
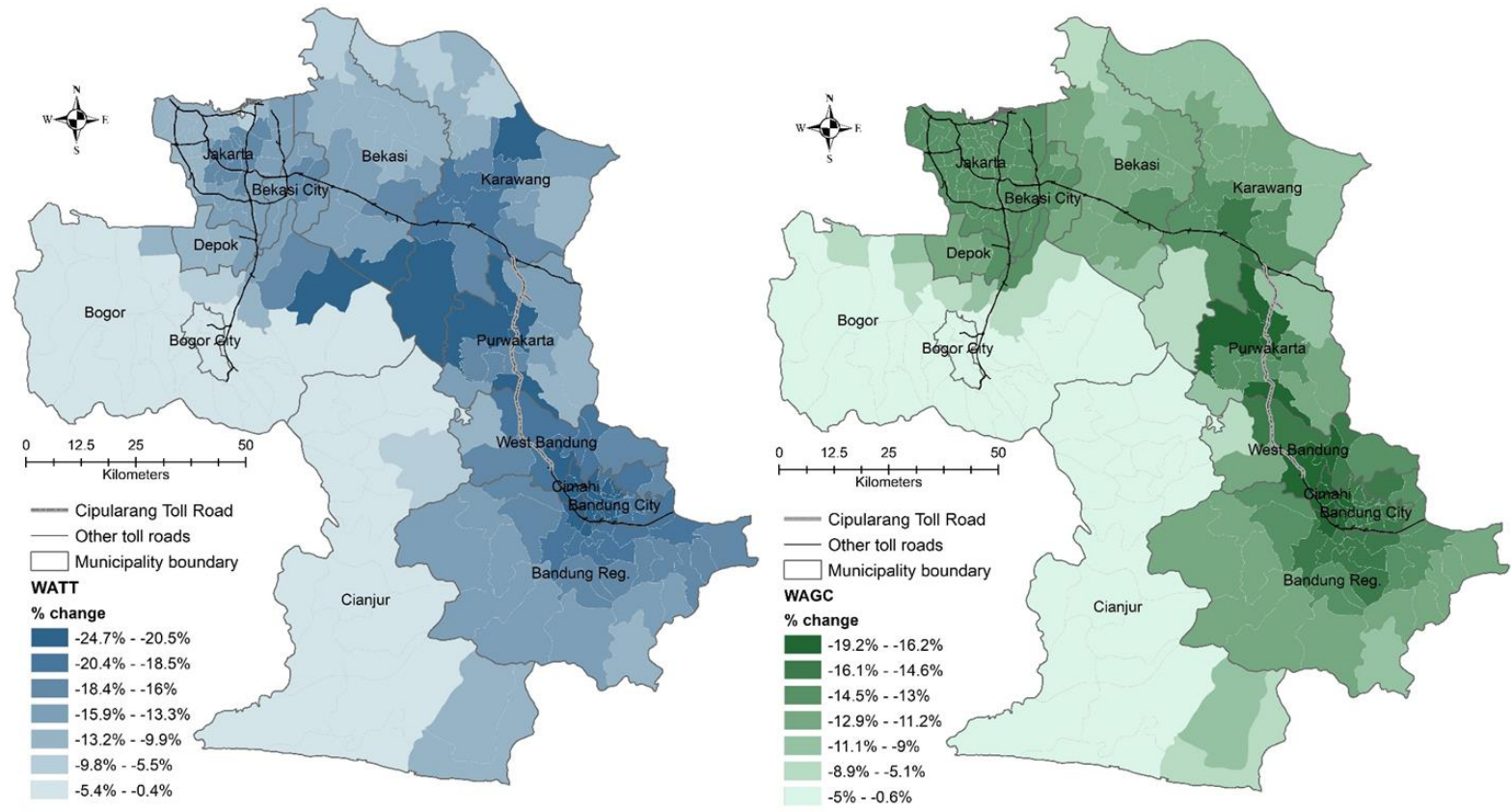

Figure 3.7. Relative difference of weighted average travel time (left) and weighted average generalised cost (right) between districts

Table 3.3. Descriptive statistics of estimated average travel time and generalised cost

\begin{tabular}{|l|l|c|c|}
\hline \multicolumn{2}{|c|}{ Statistics } & \multicolumn{2}{c|}{ Measures } \\
\cline { 3 - 4 } \multicolumn{2}{|c|}{} & Average travel time (in minutes) & $\begin{array}{c}\text { Average generalised cost } \\
\text { (in thousands IDR) }\end{array}$ \\
\hline \multirow{3}{*}{$\begin{array}{l}\text { With Cipularang } \\
\text { toll road }\end{array}$} & mean & 154.5 & 231.7 \\
\cline { 2 - 4 } & $\max$ & 332.6 & 453.8 \\
\cline { 2 - 4 } & $\min$ & 109.4 & 180.3 \\
\cline { 2 - 4 } $\begin{array}{l}\text { Without } \begin{array}{l}\text { Cipularang } \\
\text { road }\end{array} \\
\text { toll }\end{array}$ & mean & 36.5 & 43.6 \\
\cline { 2 - 4 } & max & 167.5 & 233.4 \\
\cline { 2 - 4 } & min & 335.1 & 454.3 \\
\cline { 2 - 4 } & stdev & 129 & 180.6 \\
\hline
\end{tabular}

\subsubsection{Potential accessibility measures}

Table 3.4 presents the results of various accessibility measures, weighted by the working population in each zone. Accessibility measures with time decay showed more significant changes than measures with generalised cost impedance. This indicates an overestimation of 
the impact as it is only takes into account the travel time. It is worth noting that the result of each accessibility measures in this study is different from each other, though complementary to each other. Moreover, the potential accessibility measures particularly highlight differences on job accessibility between large urban agglomerations and rural areas.

Furthermore, the Shen index shows the proportion between the potential number of jobs that can be accessed and the potential demand for jobs. Several districts in Jakarta and Purwakarta have Shen indices equal to one, which indicates that the number of jobs and the size of the working population are in balance. A district in Bekasi, known as the largest industrial area in Indonesia, has a Shen index of more than 2, which signifies that there are more jobs available than workers. However, in contrast with other measures, the Shen index is lower in the scenario with the Cipularang toll road (see Figure 3.8). The reason is that the Cipularang toll road not only increased job accessibility, but also working population accessibility. The Shen index decreases the strongest in job-poor area between Jakarta and Bandung. The construction of the Cipularang toll road also enabled the working population in the two large cities to access new jobs emerging in the new industrial areas along the toll road.

Previous findings by Dorodjatoen (2009) strengthen this result. He pointed out that the number of large and medium-sized industries has increased by almost $15 \%$ in Purwakarta, and suggested that the industrial relocation was due to the proximity to Jakarta and the availability of cheaper labour. The growth of new settlement areas was also observed in Purwakarta. Dorodjatoen found that people from Bandung and Jakarta were the predominant residents of the new settlements. The construction of the Cipularang toll road enabled them to obtain less expensive housing in Purwakarta and commute daily to one of the two big cities.

Table 3.4. Results of accessibility measures.

\begin{tabular}{|l|l|c|c|}
\hline \multirow{2}{*}{$\begin{array}{c}\text { Weighted } \\
\text { accessibility } \\
\text { measures }\end{array}$} & \multicolumn{1}{|c|}{ Scenario } & \multicolumn{2}{|c|}{ Impedance } \\
\cline { 2 - 4 } & & Time & Generalised cost \\
\hline \multirow{2}{*}{$\begin{array}{l}\text { Working population } \\
\text { accessibility }\end{array}$} & With the toll road & $8,135,674$ & $11,304,273$ \\
\cline { 2 - 4 } & Without toll road & $7,804,450$ & $11,264,201$ \\
\cline { 2 - 4 } & Relative change & $4.2 \%$ & $0.4 \%$ \\
\hline \multirow{3}{*}{ Shen index } & With the toll road & 0.73 & 0.73 \\
\cline { 2 - 4 } & Without toll road & 0.78 & 0.74 \\
\cline { 2 - 4 } & Relative change & $-5.6 \%$ & $-0.41 \%$ \\
\hline \multirow{2}{*}{$\begin{array}{l}\text { Potential } \\
\text { accessibility }\end{array}$} & With the toll road & $6,016,274$ & $8,251,967$ \\
\cline { 2 - 4 } & Without toll road & $5,755,050$ & $0.4 \%$ \\
\cline { 2 - 4 } & Relative change & $4.5 \%$ & \\
\hline
\end{tabular}

\footnotetext{
${ }^{6}$ in comparison with the situation without the Cipularang toll road
} 


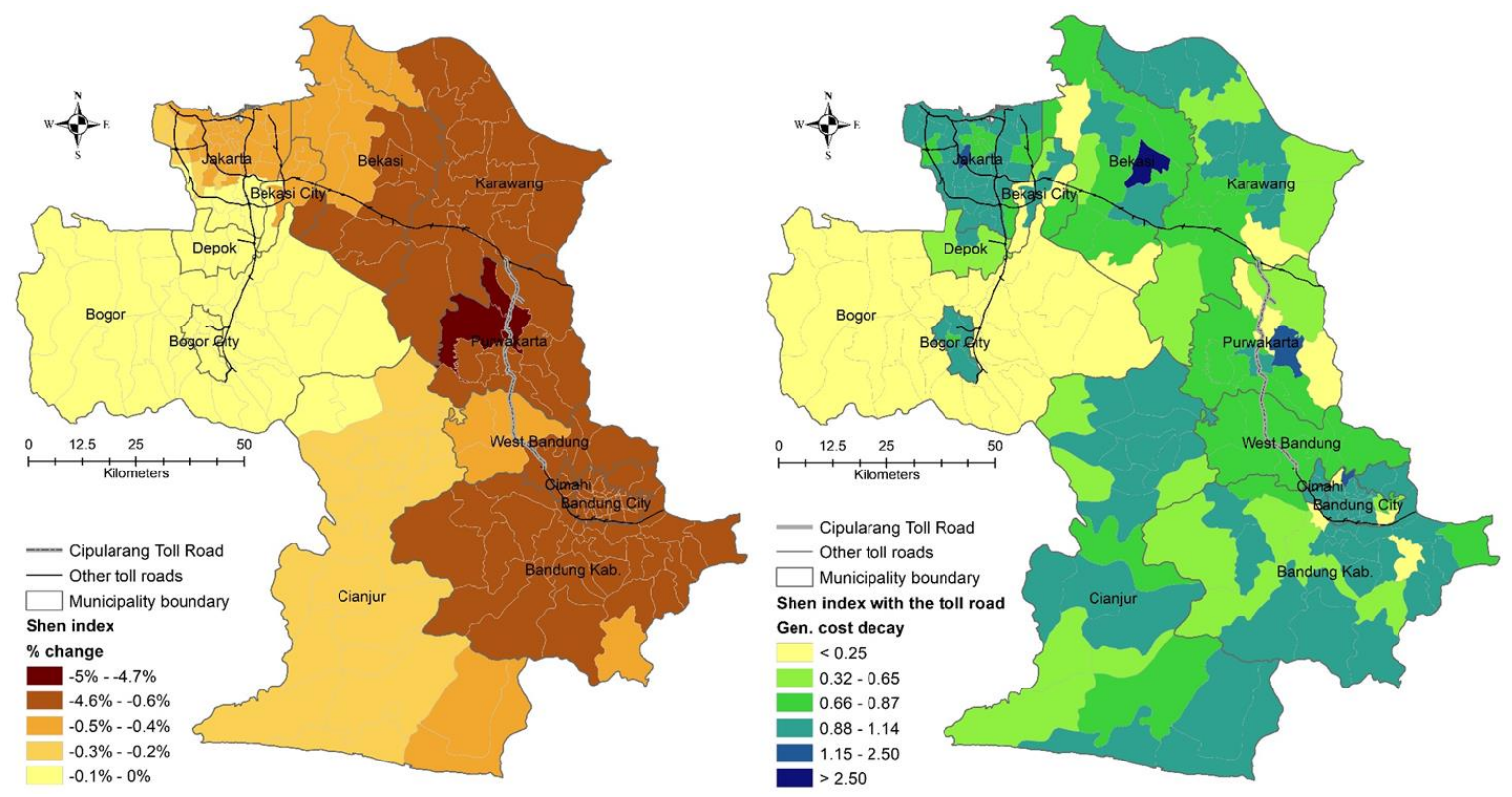

Figure 3.8. Relative changes in Shen index with generalised cost decay (left) and Shen index with the toll road (right)

\subsubsection{Spatial equity evaluation}

\section{Equity indices}

Table 3.5 shows the results for both equity indices with the Shen index and with potential job accessibility using generalised cost decay; both are weighted by working population. Accessibility measures with time decay were not included in the equity analysis as it only took the travel time into account. This led to overestimation of the accessibility impact of the toll road and, therefore, was not a good approach to measure the inequity.

In general, we found that the construction of the toll road had no impact on the average level of spatial equity as shown by the values of the Palma ratio and Gini coefficient with regard to potential job accessibility, and of the Palma Ratio using the Shen index. However, we observed a slight increment of the Gini coefficient using the Shen index. This indicates that, overall, the introduction of the toll road has benefited high-to-medium income workers more than lowincome workers, but the Palma ratio shows that people in the top 10\% of incomes did not benefit more from the toll road than those in the lowest $40 \%$.

That said, this result is not fully representative, as mode choice was not taken into account. In Indonesia, low-income workers rely on motorcycles (Herwangi, Pradono, Syabri, \& Kustiwan, 2015; Susilo, Tjoewono, Santosa, \& Parikesit, 2007), which are not allowed on most toll roads. In practice, this means that higher-income workers benefit more than lower-income workers. (See Chapter 5 for a more elaborate discussion on how the travel behaviour of various population segments is affected by the Cipularang toll road.) 
Table 3.5. Equity indices

\begin{tabular}{|l|l|c|c|}
\hline \multicolumn{1}{|c|}{$\begin{array}{c}\text { Accessibility measures (with } \\
\text { generalized cost decay) }\end{array}$} & \multicolumn{1}{|c|}{ Scenario } & $\begin{array}{c}\text { Palma } \\
\text { ratio }\end{array}$ & Gini coefficient \\
\hline $\begin{array}{l}\text { Shen index (weighted by working } \\
\text { population) }\end{array}$ & with the toll road & 1.10 & 0.30 \\
\cline { 2 - 4 } & without the toll road & 1.10 & 0.29 \\
\hline $\begin{array}{l}\text { Potential job accessibility (weighted } \\
\text { by working population) }\end{array}$ & with the toll road & 1.14 & 0.38 \\
\cline { 2 - 4 } & Without the toll road & 1.14 & 0.38 \\
\hline
\end{tabular}

\section{Cluster analysis}

The Gini index and Palma ratio (see previous section) do not explain the spatial distribution of the changes in equity and the characteristics of districts that are most likely to benefit from the new toll road. This section, therefore, presents the results of an analysis of the spatial distribution of accessibility carried out with a two-step cluster method.

As all types of potential accessibility (labour market, job and Shen index) are highly correlated $(>0.9)$, we only included the Shen index, using generalised cost decay, in the cluster analysis. We also considered residential land use growth, monthly expenditure, number of jobs and working population of the areas in the analysis, as explained in Section 3.3.3.

Figure 3.9 and Table 3.6 show the cluster map and the profiles of each cluster containing the mean of each variable (cluster centre), respectively. We obtained three final clusters (based on minimum BIC value), which we distinguished these clusters as: (1) affected areas, (2) unaffected and more urbanized districts and (3) unaffected and less urbanized districts.

Cluster 1 accounts for $2.6 \%$ of the in total 229 districts in the area. This cluster has the lowest relative change in the Shen index (-2\%), while the changes in the other clusters are almost zero, thus this cluster experienced increased inequity. This can also be seen in the mismatch between number of jobs and the size of the working population. This cluster can also be characterized as highly accessible, as it is situated close to the toll gates and has the highest reduction of average travel time relative to the situation before the construction of the Cipularang toll road (see Figure 3.7), with the highest expenditure per capita as well. This result also in line with the result of Shen index, as shown in Figure 3.8. It is consistent with the findings of several studies that the most affected areas by the construction of new motorways were areas along the roads and close to the exits (Ghani et al., 2012; Ji et al., 2014).

The shares of the number of jobs and the size of the working population in the other two clusters are somewhat proportional. However, Cluster 2 (unaffected and more urbanized districts) can be characterized as more urbanized due to its large number of workers and jobs, as well as its high rate of residential land use growth. This cluster accounts for $19.2 \%$ of the total districts in the region. Furthermore, Cluster 3 (unaffected and less urbanized districts) contains most districts in the study area $(78.2 \%)$. This cluster is characterized by the lowest number of jobs and smallest working population, lowest average monthly expenditure and lowest residential land use growth.

These results highlight that the construction of a new toll road can have significant spatial equity impacts on areas close to the toll gates. The decreased travel times and the emergence of new employment along the toll road corridor increases the number of workers who can access employment. This cluster result explains the results of both equity indices (Palma ratio and Gini coefficient). 
Table 3.6. Final cluster centres

\begin{tabular}{|l|c|c|c|c|}
\hline \multirow{2}{*}{ Variables } & \multicolumn{4}{|c|}{ Cluster centre } \\
\cline { 2 - 5 } & $\begin{array}{c}\text { Cluster 1 - } \\
\text { affected } \\
\text { districts }\end{array}$ & $\begin{array}{c}\text { Cluster 2 - } \\
\text { Unaffected } \\
\text { and more } \\
\text { urbanized }\end{array}$ & $\begin{array}{c}\text { Cluster 3 - } \\
\text { Unaffected } \\
\text { and less } \\
\text { urbanized }\end{array}$ & Combined \\
\hline Shen-index relative change & $-2.02 \%$ & $-0.34 \%$ & $-0.48 \%$ & $-0.49 \%$ \\
\hline $\begin{array}{l}\text { Monthly expenditure per capita } \\
\text { (in thousands IDR) }\end{array}$ & 8626 & 2473 & 1342 & 1750 \\
\hline $\begin{array}{l}\text { Residential land use growth } \\
\text { (2004-2013) }\end{array}$ & $5.0 \%$ & $5.2 \%$ & $2.9 \%$ & $3.4 \%$ \\
\hline Working population & 104,303 & 155,695 & 54,766 & 75,456 \\
\hline Number of jobs & 14,526 & 138,027 & 36,204 & 55,201 \\
\hline
\end{tabular}

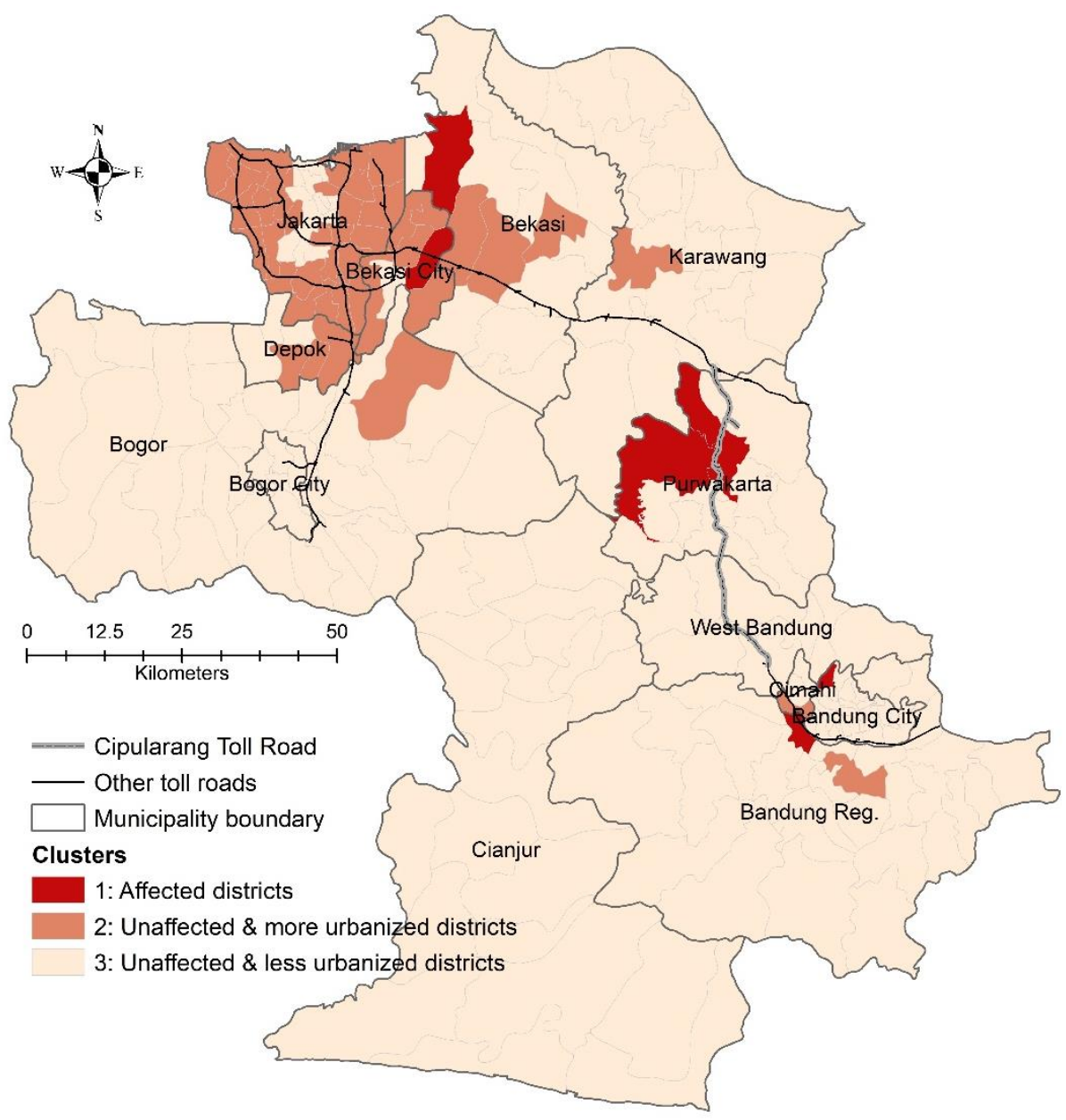

Figure 3.9. Cluster map 


\subsection{Conclusions}

We have examined the impact of the Cipularang toll road in Indonesia on job accessibility and spatial equity by isolating the effect of the toll road. We applied a macroscopic traffic simulation model to obtain valid estimates of travel time and generalised cost. Job competition, represented by the Shen index, was also measured to reflect the distributions of employment and working population. We assessed the equity impact by using the Palma ratio, Gini coefficient and spatial distribution of the accessibility changes with a two-step cluster analysis.

We found that area along the toll road and close to the toll gates are the most affected by the construction of the Cipularang toll road. Our analysis shows that the construction of the Cipularang toll road has reduced the average travel time in the Jakarta-Bandung area by $13 \%$. For specific origin-destination pairs, the travel time is now up to 1.5 times shorter. The accessibility analysis shows that the choice of the indicator affects the results. Employment and working population accessibility have increased by $5 \%$. However, the toll road also increases job competition as more workers can access jobs available in the job-poor area in between Jakarta and Bandung, resulting in a small decrease in the amount of accessible jobs per worker. Most affected areas have a relatively large working population compared to number of jobs and experienced residential land use growth. We can conclude that a new toll road in developing countries with un-mature road networks can have positive as well as negative impacts on the areas close to it.

This study adds to the literature by examining job accessibility and spatial equity impacts of a major toll road in a developing country context with the addition of congestion effects and stated choice-based value of time in the traffic simulation. However, our research also has limitations. Firstly, we did not examine the impact of the toll road on spatial developments, e.g. distribution of employment, population or housing costs. The inclusion of these data in the measurement certainly will affect the potential job accessibility measure. Secondly, we were not able to estimate job accessibility for different worker groups as reliable sector-level employment data or detailed data on the working population are not available at a high spatial resolution in Indonesia. Finally, this study did not consider the complexity and differences of individual travel behaviour. It is important to incorporate the availability of transport modes at individual level, as in Indonesia, low-income workers rely on motorcycles, which are not allowed on most toll roads. Therefore, higher income workers can benefit more than lowerincome workers. 


\title{
4. Residential location choice
}

This chapter is based on: Andani, I.G.A., La Paix Puello, L., \& Geurs, K. (2019). Exploring the role of toll road construction on residential location choice in Jakarta - Bandung Region. Submitted for publication in Journal of Case Studies on Transport Policy.

\begin{abstract}
This chapter deals with the influence of the construction of a major toll road on residential location preferences in the Jakarta - Bandung region in Indonesia. A hybrid choice model (HCM) was developed to model the effects of socio-economics, travel characteristics, housing characteristics and latent variables on residential location choice simultaneously. The latent variable (LV) model is composed of satisfaction with current neighbourhood and satisfaction with housing. The discrete choice model (DCM) using a mixed logit model (MLM), excluding the latent variables, was also estimated. The models were based on survey data collected from 1,600 respondents. The results show that the addition of latent variables that reflect the satisfaction of individuals with neighbourhood accessibility, dwelling size and affordability, led to a higher probability that low-income individuals will move house. Satisfaction with neighbourhood characteristics is more significant than satisfaction with housing to influence residential location choice. Furthermore, high-income earners were willing to pay higher land taxes to live closer than $5 \mathrm{~km}$ to the toll road to capture travel time benefits, whereas people in other income segments preferred to live beyond $10 \mathrm{~km}$ from the toll gate where housing costs tend to be low. However, spatial location components were found to have a stronger influence on neighbourhood and housing satisfaction levels than socio-economic characteristics.
\end{abstract}

Keyword: residential location choice, toll road, hybrid choice model 


\subsection{Introduction}

The construction of major road infrastructure, such as a motorway, has long been known to stimulate land use changes, not only along the corridor of the road but also spilling over into nearby areas. Several studies have investigated the effect of the construction of a major road on land use development. Most found evidence of urban growth along the corridor or in the distance to the motorway exit (see, for example, Aljoufie et al., 2013; Chi, 2010; Ji et al., 2014; Müller et al., 2010). Changes in accessibility that result from the interaction of land use and transportation infrastructure could influence preferences for residential location (Kim et al., 2005; Wegener \& Fürst, 2004).

This study's aim is to gain a better understanding of how the construction of a major toll road affects land use developments in a developing country. So far, the effects of road tolls on household residential relocation have been studied in mature networks in developed countries. For instance, Eliasson and Mattsson (2001) investigated transport and location effects of congestion pricing in Stockholm and found that congestion pricing caused the city to become less dispersed and the inner suburban area to gain more households.

This study adds to the literature by examining the impact of a major toll road on residential location choice in a developing country context with underdeveloped road networks. This study uses the Cipularang toll road in Indonesia as a case study, which after its opening in 2005 shortened the travel time between Jakarta and Bandung significantly. Studies into residential relocation and travel behaviour in response to a toll road or motorway construction in developing countries are limited in the literature, although several studies have found significant deviations from developed countries. For instance, residential relocation decisions in developing countries are often strongly influenced by affordability (Kumarage, 2005; Sharma \& Chandrasekhar, 2014) or social networks (Limbumba, 2010). In developing countries, the maximum amount of travel time that people are willing to allocate is also greater than in developed countries (Banerjee et al., 2007), and the same applies with regard to travel budget (Bocarejo \& Oviedo, 2012). This, of course, can also affect the selection of the housing location.

The added value of this study is twofold. For starters, it is the first comprehensive ex-post evaluation of toll road construction in the context of developing countries, using revealed and stated preference data. Few quantitative studies are available on the impact of road infrastructure on residential location choice in developing countries. To the author's knowledge, no studies have looked at the effect of toll roads in this context. They add complexity as they introduce explicit trade-offs between travel time savings and toll fee costs. Earlier studies in Indonesia such as by Nurlaela and Curtis (2012) did not involve any mathematical modelling or a representative sample of the population. Secondly, this study includes the application of a traditional mixed logit model and a hybrid choice model to analyse the effect of people's satisfaction with aspects of their living environment on residential location choice within the context of the construction of a new toll road, and distance to toll gate. The addition of latent variables makes this study also an improvement on existing work on the effect of toll costs on residential preferences (e.g. Arentze \& Timmermans, 2007; Tillema et al., 2010). The latent variables represent psychological factors (e.g. perception of individuals toward their residence's accessibility, affordability, etc.) which are unobservable and are expected to be key factors that characterise the underlying behaviour to relocate.

The rest of the study is organised as follows. After this introduction, we present the theoretical framework of the study. Then we explain the case study and data collection. Section 4.4 explains the methodology, including the model structure and specifications. The estimation 
results are presented in Section 4.5. Finally, Section 4.6 describes the conclusions and directions for future research.

\subsection{Factors affecting residential location choice}

Numerous studies have explored the factors that affect residential location choice. Important determinants that influence housing choices include the characteristics of dwelling and neighbourhood, accessibility, socio-demographic characteristics, as well as an individual's lifestyle or preferences (which are latent factors). Figure 4.1 shows the conceptual model that accommodates residential location choice, toll road construction and other influencing factors; the ellipse with a dashed line represents unobserved (latent) variables.

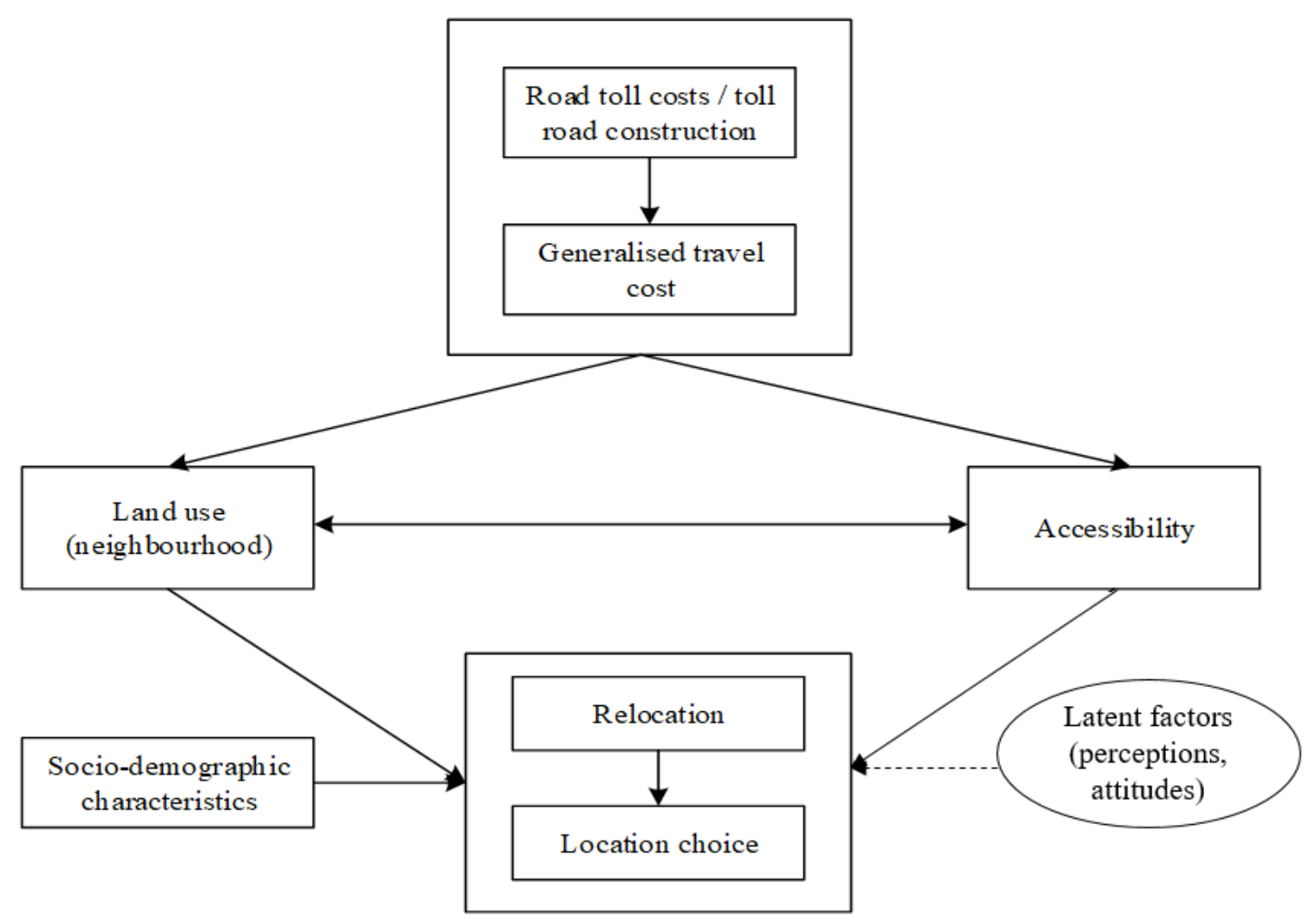

Figure 4.1. Conceptual framework for residential location choice, toll road construction and other influencing factors

\subsubsection{Toll road construction, accessibility and neighbourhood characteristic}

Many studies have found a relationship between accessibility indicators and housing choices, for example travel time to work (Kim et al., 2005; Vega \& Reynolds-Feighan, 2009), travel (monetary) cost to work (Olaru et al., 2011; Tillema et al., 2010), accessibility of various urban facilities (Chen et al., 2008; Haugen et al., 2012; Kortum et al., 2012) and distance to main roads (de Palma, Motamedi, Picard, \& Waddell, 2005; Huu Phe \& Wakely, 2000). Tillema et al. (2010), moreover, found that people are more sensitive to travel costs, including toll and fuel 
costs, than to housing costs, to choose residential location. Therefore, it is essential to analyse the effects of neighbourhood accessibility in residential location choice.

\subsubsection{Socio-demographic characteristics}

Previous studies have shown that socio-demographic aspects are essential determinants in residential location preferences (Bailey \& Livingston, 2008; Lee \& Waddell, 2010). For instance, pensioners tend to choose environments that are quieter or close to relatives (Gobillon \& Wolff, 2011), while young people who just graduated prefer to live closer to employment opportunities or city centres. Housing characteristics, such as house price, mortgage rates or rent cost (Choudhury \& Ayaz, 2015; Olaru et al., 2011; Tillema et al., 2010), housing quality (Molin \& Timmermans, 2003; Ozturk \& Irwin, 2001), tenure type (Eluru et al., 2008; Frenkel, Bendit, \& Kaplan, 2013), and the length of residency (Böheim \& Taylor, 2002; Clark, 2013), also play a significant role in residential location choice. Some studies revealed that travel characteristics, such as car ownership (Cervero, 1998; Prashker, Shiftan, \& HershkovitchSarusi, 2008) and regular mode preferences (Abraham \& Hunt, 1997; Pinjari, Pendyala, Bhat, \& Waddell, 2011) have significant effects on housing choices as well. Research has also revealed a significant interdependence between socio-demographic factors, home and workplace location, and transport mode preferences in residential location choices (see discussions in Liao et al., 2015; Walker \& Li, 2007).

\subsubsection{Latent factors}

The observable explanatory variables mentioned in the previous section are linked to latent (non-observable) factors. By taking latent factors into account, we can capture unobserved heterogeneity and improve the behavioural representation of the traditional discrete choice model (more discussions can be seen in Walker, 2001).

Various studies have used integrated choice models and latent variables to model residential preference (see, for example, Kitrinou, Polydoropoulou, \& Bolduc, 2010; Liao et al., 2015; Olaru et al., 2011; Smith \& Olaru, 2013). Those studies also found that latent constructs, related to the importance of particular dwelling and neighbourhood characteristics, explained residential preferences better than socio-demographic variables (Liao et al., 2015; Olaru et al., 2011). Residential satisfaction also acts to express the effects of socio-demographic and neighbourhood characteristics on residential relocation (Speare, 1974). It is considered as a factor that push people to move (Clark \& Onaka, 1983). This study enriches current literature with the addition of latent factor of current residential satisfaction to develop residential location choice model in toll context.

\subsection{Case study and data collection}

\subsubsection{Case study}

The construction of the Cipularang toll road began in 2002 to connect two major Indonesian metropolitan areas, the Jakarta Metropolitan Area (JMA) and the Bandung Metropolitan Area (BMA), and ended in 2005 (see Figure 4.2). The toll road shortened the travel time between Jakarta and Bandung from around five hours to two hours.

The distance is about $180 \mathrm{~km}$ and the modal split has been dominated by cars at $95.8 \%$ (Lubis et al., 2005). Note that toll roads are very different from local roads or untolled motorways, as transport in Indonesia is dominated by motorcycles. Ten years after the Cipularang Toll Road became fully operational, the Jakarta - Bandung corridor had become the busiest corridor in 
Java. It is characterised by a combination of socioeconomic activities, including industry, agriculture, commerce and residential, which in turn has created very intensive rural-urban linkage, and blurred rural-urban distinctions (Firman, 2009). We believe that those changes were caused by the presence of the Cipularang Toll Road, although, to the best of our knowledge, there are no studies into the effects of toll road developments on spatial developments in Indonesia.

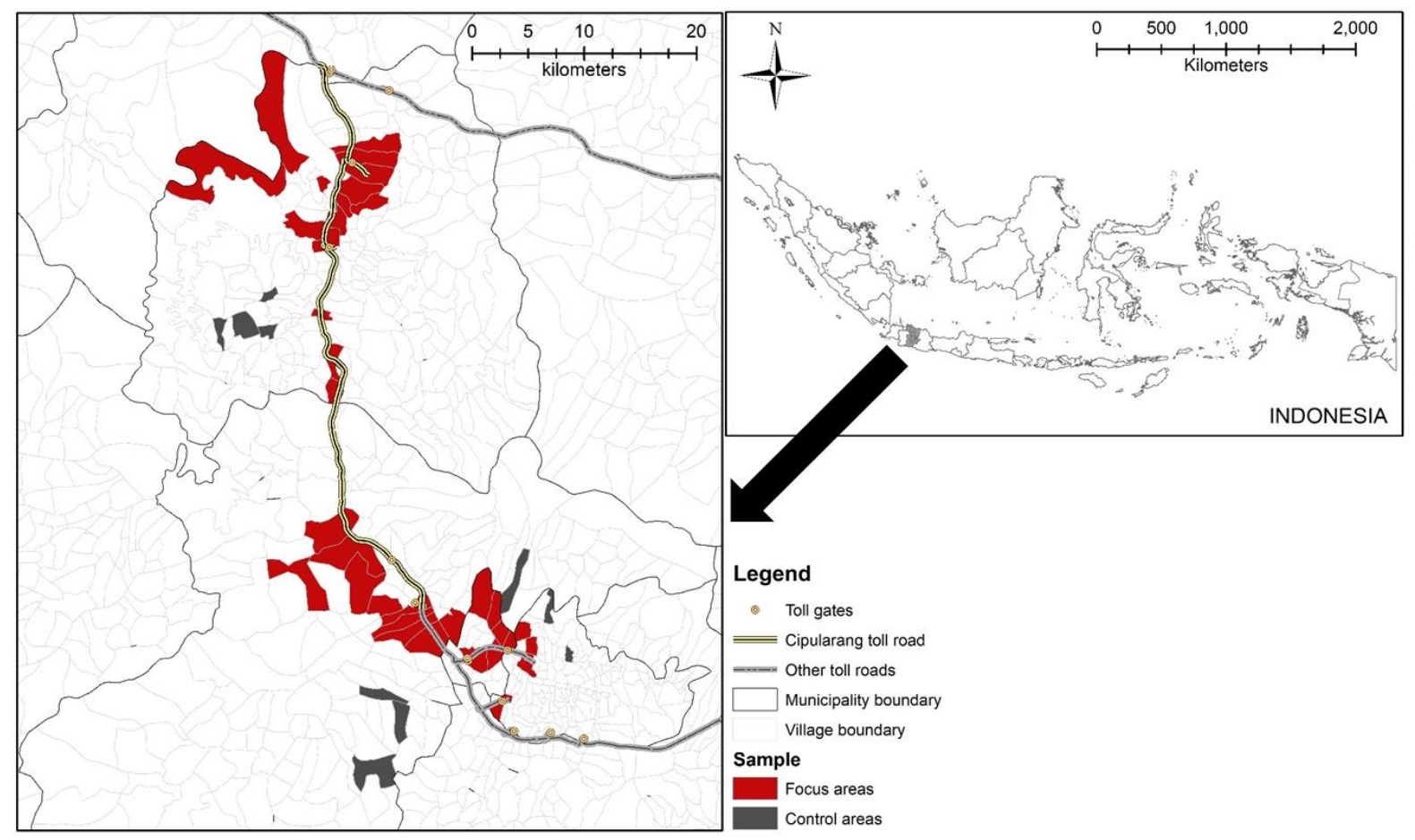

Figure 4.2. Study region

\subsubsection{Survey design and data}

We targeted 35 villages within a 5-km buffer from the Cipularang toll road that experienced major land use changes. The sample area covers (1) Purwakarta, (2) West Bandung, (3) Bandung City and (4) Cimahi. As Purwakarta has more toll gates and experienced stronger residential land use changes, this area was oversampled in the survey, we also wanted to investigate the causal link between the toll road and land use development. Ten sub-districts located between 6 and $12 \mathrm{~km}$ from the toll road were included in the sample as the control area. The respondents were sampled on the basis of stratified random sampling and grouping was based on the proportion of gender and age relative to the overall population.

We collected data from 1,600 workers using computer-aided personal interview (CAPI) technology. We found respondents who liked to cooperate through a door-to-door survey and conducted the interviews on location, with the aid of a tablet. Table 4.1 shows the proportion among municipalities and socio-demographic representation in our sample. The number of respondents in each municipality mainly considered the amount of residential land use increased and the number of toll gates in target areas. Moreover, due to data limitations, we were only able to retrieve data for gender proportion, average productive age and the average 
household size at the municipal level (BPS, 2017a). Based on socio-demographic representation, the sample appears to be demographically representative.

Table 4.1. Representation of socio-demographic characteristics in the sample (comparison with population data in 2016)

\begin{tabular}{|c|c|c|c|c|c|c|}
\hline & Purwakarta & $\begin{array}{l}\text { West } \\
\text { Bandung }\end{array}$ & Cimahi & Bandung & $\begin{array}{l}\text { All } \\
\text { municipalities }\end{array}$ \\
\hline \multicolumn{2}{|c|}{$\begin{array}{l}\text { Residential land use } \\
\text { increased (ha)* }\end{array}$} & 1718.7 & 1176.5 & 1012.7 & 620.0 & 4527.9 \\
\hline \multicolumn{2}{|c|}{$\begin{array}{l}\text { Number of toll gates in the } \\
\text { study area* }\end{array}$} & 3 & 2 & 1 & 1 & 7 \\
\hline \multicolumn{2}{|c|}{ Number of population* } & $\begin{array}{l}143,561 \\
(24.0 \%)\end{array}$ & $\begin{array}{l}167,261 \\
(27.0 \%)\end{array}$ & $\begin{array}{l}214,231 \\
(34.5 \%)\end{array}$ & $\begin{array}{l}99,821 \\
(14.4 \%)\end{array}$ & 624,874 \\
\hline \multicolumn{2}{|c|}{$\begin{array}{l}\text { Number of respondents } \\
\text { (sample) }\end{array}$} & $\begin{array}{c}624 \\
(38.5 \%)\end{array}$ & $\begin{array}{c}504 \\
(31.1 \%)\end{array}$ & $\begin{array}{c}306 \\
(18.9 \%)\end{array}$ & $\begin{array}{c}188 \\
(11.6 \%)\end{array}$ & 1,622 \\
\hline \multirow{2}{*}{$\begin{array}{l}\text { Gender } \\
\text { proporti- } \\
\text { on }\end{array}$} & Population** & $50.9 \%$ & $50.8 \%$ & $50.4 \%$ & $50.5 \%$ & $50.6 \%$ \\
\hline & Sample & $63.1 \%$ & $46.7 \%$ & $28.8 \%$ & $49.7 \%$ & $49.9 \%$ \\
\hline \multirow{2}{*}{$\begin{array}{l}\text { Average } \\
\text { produc- } \\
\text { tive age }\end{array}$} & Population** & 34.5 & n.a. & 34.8 & 35.4 & 35.2 \\
\hline & Sample & 37.8 & 35.7 & 37.1 & 36.7 & 36.9 \\
\hline \multirow{2}{*}{$\begin{array}{l}\text { Average } \\
\text { household } \\
\text { size }\end{array}$} & Population** & 3.8 & 3.7 & 3.7 & 3.8 & 3.7 \\
\hline & Sample & 3.3 & 1.2 & 3.3 & 1.4 & 3.4 \\
\hline
\end{tabular}

* Data in selected 45 villages

** Data in the municipality levels. Source: BPS (2017a)

\section{Stated-choice experiment}

The design of the stated-choice (SC) experiment in our study followed a methodological approach suggested by Louviere, Hensher, and Swait (2000). Firstly, the attributes in the experiment should be identified. We included four attributes in each choice card: (1) land tax or rent per month, (2) travel (monetary) cost to work, (3) travel time to work and (4) distance to the toll gate. Secondly, the measurement unit for each attribute should be specified to prevent any ambiguity. For instance, monetary variables represent the local currency (IDR) and travel time is in minutes. Distance to the toll gate, although provided in an ordinal scale, is described with a range expressed in kilometres.

Thirdly, the magnitude of attribute levels should be sufficiently varied but still realistic. Since the travel cost, housing cost and travel time to work declared by the respondents in the revealed preference (RP) survey were in a wide range (see Table 4.4), we defined the attribute levels in the SC experiment as percentage variations of the revealed data, which are $-75 \%,-25 \%,+25 \%$ and $+75 \%$ of the current situation (Table 4.2 ).

Moreover, threshold values had to be well-defined to ensure that respondents would be able to consider small differences (Cherchi \& Ortúzar, 2002). Therefore, we also verified that the values in the design would cover significant differences in the RP data. For instance, rent and land tax value ranges between 25 and 3500 (in thousand IDR) in our data, and the mean is 459.7 (see Table 4.4). Differences of $-75 \%$ and $+75 \%$ from the mean value resulted in values of 344.8 and 804.5 ; these are significant variations relative to the sample. Pivoting around the RP data makes the SC experiment more realistic and enables preferences to be expressed in a context 
extreme decision. People might not find a new house according to their preferences or might not be able to afford it. Omitting those respondents from the sample was found to have no influence on the model fit. We, therefore, included this behaviour as an explanatory variable.

\section{Travel-related variables}

The travel-related variables include travel mode on a daily basis and the number of cars owned in the household. Moreover, we also incorporated the respondent's characteristics concerning behaviour toward the Cipularang toll road, by including the frequency of trips via the toll road. A respondent who uses the toll road more than once a week is categorised as a frequent user.

\section{Neighbourhood characteristics}

The neighbourhood characteristics account variable relates to the place where the respondents live, such as the municipality, urban area and the vicinity to the toll gate. Furthermore, the urban area is identified based on the population size and building density. Regarding the influence of the toll road, we also categorised the study area into buffer and control areas. The buffer area is the area within $5 \mathrm{~km}$ from the toll gate and the control area is the area beyond a distance of 5 $\mathrm{km}$ from the toll gate.

Table 4.4. Statistics of variables in residential location choice model

\begin{tabular}{|l|l|l|l|l|l|l|}
\hline \multicolumn{1}{|c|}{ Variables } & \multicolumn{1}{|c|}{$\begin{array}{c}\text { Notation } \\
\text { parameter }\end{array}$} & \multicolumn{1}{|l|}{$\mathrm{N}$} & Minimum & Maximum & Mean & St. dev \\
\hline $\begin{array}{l}\text { Stated choice attributes } \\
\begin{array}{l}\text { Travel time to work } \\
\text { location (minutes) }\end{array}\end{array}$ & $\beta_{\text {time }}$ & 9462 & 1.00 & 360.00 & 29.86 & 31.99 \\
\hline $\begin{array}{l}\text { Travel cost to work } \\
\text { location (x1000 IDR) }\end{array}$ & $\beta_{\text {cost }}$ & 9462 & 0.00 & 500.00 & 20.10 & 32.48 \\
\hline $\begin{array}{l}\text { Rent or land tax } \\
\text { (x1000 IDR) }\end{array}$ & $\beta_{\text {rent }}$ & 9462 & 25.00 & 3500.00 & 459.67 & 742.29 \\
\hline $\begin{array}{l}\text { Dummy of distance to } \\
\text { toll gate (less than 2 } \\
\text { km) }\end{array}$ & $\beta_{\text {proxyless2km }}$ & 9462 & 0.00 & 1.00 & 0.18 & 0.40 \\
\hline $\begin{array}{l}\text { Dummy of distance to } \\
\text { toll gate (2-5 km) }\end{array}$ & $\beta_{\text {proxy2-5km }}$ & 9462 & 0.00 & 1.00 & 0.40 & 0.48 \\
\hline $\begin{array}{l}\text { Dummy of distance to } \\
\text { toll gate (5-10 km) }\end{array}$ & $\beta_{\text {proxy5-10km }}$ & 9462 & 0.00 & 1.00 & 0.27 & 0.44 \\
\hline $\begin{array}{l}\text { Dummy distance to } \\
\text { toll gate (more than 2 } \\
\text { km) }\end{array}$ & $\beta_{\text {morethan10km }}$ & 9462 & 0.00 & 1.00 & 0.16 & 0.36 \\
\hline $\begin{array}{l}\text { Non-choosing } \\
\text { behaviour (stick to the } \\
\text { same alternative) }\end{array}$ & $\beta_{\text {non-choosing }}$ & 9462 & 0.00 & 1.00 & 0.32 & 0.47 \\
\hline Socio-demographic variables & $\beta_{\text {male }}$ & 9462 & 0.00 & 1.00 & 0.50 & 0.50 \\
\hline \begin{tabular}{l} 
Gender (male =1) \\
\hline Age
\end{tabular} & $\lambda_{\text {age }}$ & 9462 & 18.00 & 75.00 & 36.88 & 11.85 \\
\hline Age over 50 & 9462 & 0.00 & 1.00 & 0.18 & 0.38 \\
\hline $\begin{array}{l}\text { Dummy of low- } \\
\text { income }\end{array}$ & $\beta_{\text {low-income }}$ & 9462 & 0.00 & 1.00 & 0.30 & 0.46 \\
\hline $\begin{array}{l}\text { Dummy of middle- } \\
\text { income }\end{array}$ & $\beta_{\text {mid-income }}$ & 9462 & 0.00 & 1.00 & 0.54 & 0.50 \\
\hline
\end{tabular}




\begin{tabular}{|c|c|c|c|c|c|c|}
\hline Variables & $\begin{array}{l}\text { Notation } \\
\text { parameter }\end{array}$ & $\mathrm{N}$ & Minimum & Maximum & Mean & St. dev \\
\hline Dummy high-income & $\beta_{\text {high-income }}$ & 9462 & 0.00 & 1.00 & 0.15 & 0.36 \\
\hline $\begin{array}{l}\text { Dummy of married } \\
\text { people }\end{array}$ & $\beta_{\text {married }}$ & 9462 & 0.00 & 1.00 & 0.77 & 0.42 \\
\hline $\begin{array}{l}\text { Dummy of individual } \\
\text { with children }\end{array}$ & $\lambda_{\text {children }}$ & 9462 & 0.00 & 1.00 & 0.70 & 0.46 \\
\hline $\begin{array}{l}\text { Number of household } \\
\text { size }\end{array}$ & $\beta_{\text {housemember }}$ & 9462 & 1.00 & 11.00 & 3.38 & 1.31 \\
\hline Dummy of employee & $\lambda_{\text {employee }}$ & 9462 & 0.00 & 1.00 & 0.44 & 0.50 \\
\hline $\begin{array}{l}\begin{array}{l}\text { Dummy of } \\
\text { who are }\end{array} \\
\text { employed }\end{array}$ & $\lambda_{\text {entrepreneur }}$ & 9462 & 0.00 & 1.00 & 0.44 & 0.50 \\
\hline \multicolumn{7}{|l|}{ Travel-related variables } \\
\hline Regular mode: car & $\beta_{\text {car-user }}$ & 9462 & 0.00 & 1.00 & 0.08 & 0.27 \\
\hline $\begin{array}{l}\text { Regular mode: public } \\
\text { transport (including } \\
\text { public transport with } \\
\text { certain routes and } \\
\text { without routes, e.g. } \\
\text { taxi) }\end{array}$ & $\lambda_{\text {PT-user }}$ & 9462 & 0.00 & 1.00 & 0.72 & 0.45 \\
\hline $\begin{array}{l}\text { Regular mode: } \\
\text { motorcycle }\end{array}$ & $\lambda_{\text {motorcycle-user }}$ & 9462 & 0.00 & 1.00 & 0.15 & 0.36 \\
\hline $\begin{array}{l}\text { Commuter (travel via } \\
\text { the toll road at least } \\
\text { once a week for work } \\
\text { purpose) }\end{array}$ & $\lambda_{\text {commuter }}$ & 9462 & 0.00 & 1.00 & 0.18 & 0.39 \\
\hline $\begin{array}{l}\text { Frequent user (travel } \\
\text { via the toll road at } \\
\text { least once a week for } \\
\text { any purpose) }\end{array}$ & $\lambda_{\text {freq-user }}$ & 9462 & 0.00 & 1.00 & 0.59 & 0.49 \\
\hline $\begin{array}{l}\text { Number of cars } \\
\text { owned }\end{array}$ & $\lambda_{\text {car-owned }}$ & 9462 & 0.00 & 2.00 & 0.28 & 0.51 \\
\hline \multicolumn{7}{|l|}{$\begin{array}{l}\text { Housing } \\
\text { characteristics }\end{array}$} \\
\hline $\begin{array}{l}\text { Housing tenure (own } \\
\text { house }=1 \text { ) }\end{array}$ & $\lambda_{\text {ownhouse }}$ & 9462 & 0.00 & 1.00 & 0.67 & 0.47 \\
\hline $\begin{array}{l}\text { Dummy of housing } \\
\text { type (detached house) }\end{array}$ & $\lambda_{\text {detached }}$ & 9462 & 0.00 & 1.00 & 0.76 & 0.43 \\
\hline $\begin{array}{l}\text { Length of residence in } \\
\text { current house (years) }\end{array}$ & $\lambda_{\text {length_res }}$ & 9462 & 0.00 & 70.00 & 16.71 & 15.07 \\
\hline $\begin{array}{l}\text { Moved to the current } \\
\text { house after } 2005\end{array}$ & $\lambda_{\text {mover }}$ & 9462 & 0.00 & 1.00 & 0.58 & 0.49 \\
\hline $\begin{array}{lr}\text { Number } & \text { of } \\
\text { relocations after } & 2005\end{array}$ & $\lambda_{\text {numberofmove }}$ & 5616 & 1.00 & 4.00 & 1.18 & 0.55 \\
\hline \multicolumn{7}{|c|}{ Neighbourhood characteristics } \\
\hline Urban area & $\lambda_{\text {urban }}$ & 9462 & 0.00 & 1.00 & 0.72 & 0.45 \\
\hline Control area & $\lambda_{\text {control }}$ & 9462 & 0.00 & 1.00 & 0.20 & 0.40 \\
\hline $\begin{array}{l}\text { Distance to toll gate } \\
\text { (in km Euclidian } \\
\text { distance) }\end{array}$ & $\lambda_{\text {proxy }}$ & 9462 & 0.00 & 14.32 & 5.22 & 3.62 \\
\hline $\begin{array}{l}\text { Located in Bandung } \\
\text { municipality }\end{array}$ & $\lambda_{\text {bandung }}$ & 9462 & 0.00 & 1.00 & 0.11 & 0.31 \\
\hline
\end{tabular}




\begin{tabular}{|c|c|c|c|c|c|c|}
\hline Variables & $\begin{array}{l}\text { Notation } \\
\text { parameter }\end{array}$ & $\mathrm{N}$ & Minimum & Maximum & Mean & St. dev \\
\hline $\begin{array}{ll}\text { Located } & \text { in } \\
\text { Purwakarta } & \end{array}$ & $\lambda_{\text {purwakarta }}$ & 9462 & 0.00 & 1.00 & 0.39 & 0.49 \\
\hline Located in Cimahi & $\lambda_{\text {bandung }}$ & 9462 & 0.00 & 1.00 & 0.19 & 0.40 \\
\hline $\begin{array}{l}\text { Located in West } \\
\text { Bandung }\end{array}$ & $\lambda_{\text {west_bandung }}$ & 9462 & 0.00 & 1.00 & 0.31 & 0.46 \\
\hline \multicolumn{7}{|c|}{$\begin{array}{l}\text { Psychometric indicators - Satisfaction with housing / neighbourhood characteristics } \\
\text { (evaluation from } 1 \text { to } 5 \text { ) }\end{array}$} \\
\hline $\begin{array}{l}\text { Distance to work (for } \\
\text { myself and/or other } \\
\text { household members) }\end{array}$ & $\alpha_{\text {acc_work }}$ & 9456 & 1.00 & 5.00 & 3.65 & 0.78 \\
\hline $\begin{array}{l}\text { Distance to future } \\
\text { employment } \\
\text { opportunities (for } \\
\text { myself and/or other } \\
\text { household members) }\end{array}$ & $\alpha_{\text {acc_employ }}$ & 9438 & 1.00 & 5.00 & 3.70 & 0.83 \\
\hline $\begin{array}{l}\text { Well-connected by } \\
\text { public transport }\end{array}$ & $\alpha_{\text {acc_PT }}$ & 9438 & 1.00 & 5.00 & 3.76 & 0.76 \\
\hline $\begin{array}{l}\text { Distance to shops for } \\
\text { daily groceries }\end{array}$ & $\alpha_{\text {acc_shops }}$ & 9450 & 1.00 & 5.00 & 3.78 & 0.72 \\
\hline $\begin{array}{l}\text { Distance to school } \\
\text { and/or childcare }\end{array}$ & $\alpha_{\text {acc_school }}$ & 9408 & 1.00 & 5.00 & 3.74 & 0.76 \\
\hline $\begin{array}{l}\text { Distance to public } \\
\text { facilities (clinic / } \\
\text { hospital, recreation } \\
\text { area, mosque / } \\
\text { church) }\end{array}$ & $\alpha_{\text {acc_facilities }}$ & 9432 & 1.00 & 5.00 & 3.78 & 0.78 \\
\hline $\begin{array}{l}\text { Familiarity (close to } \\
\text { friends / family) }\end{array}$ & $\alpha_{\text {familiar }}$ & 9444 & 1.00 & 5.00 & 3.68 & 0.73 \\
\hline $\begin{array}{l}\text { Affordability of your } \\
\text { home }\end{array}$ & $\alpha_{\text {affordable }}$ & 9420 & 1.00 & 5.00 & 3.73 & 0.85 \\
\hline $\begin{array}{l}\text { Size of your housing } \\
\text { (including garden and } \\
\text { garage) }\end{array}$ & $\alpha_{\text {size }}$ & 9426 & 1.00 & 5.00 & 3.68 & 0.78 \\
\hline $\begin{array}{l}\text { Building health and } \\
\text { safety standard (e.g. } \\
\text { safe floods, } \\
\text { mudslides, fire, gas } \\
\text { and electrical risk; } \\
\text { mould and pests) }\end{array}$ & $\alpha_{\text {health }}$ & 9438 & 1.00 & 5.00 & 3.84 & 0.72 \\
\hline Number of bedrooms & $\alpha_{\text {bedroom }}$ & 9414 & 1.00 & 5.00 & 3.70 & 0.72 \\
\hline $\begin{array}{lr}\text { Little } & \text { exposure to } \\
\text { traffic } & \text { emissions } \\
\text { (noise } & \text { and/or } \\
\text { pollution) } & \\
\end{array}$ & $\alpha_{\text {emission }}$ & 9438 & 1.00 & 5.00 & 3.72 & 0.81 \\
\hline $\begin{array}{l}\text { Level of safety in } \\
\text { your neighbourhood }\end{array}$ & $\alpha_{\text {safety }}$ & 9450 & 1.00 & 5.00 & 3.86 & 0.68 \\
\hline $\begin{array}{l}\text { General appeal } \\
\text { (aesthetics) of your } \\
\text { neighbourhood }\end{array}$ & $\alpha_{\text {aesthetic }}$ & 9426 & 1.00 & 5.00 & 3.73 & 0.74 \\
\hline
\end{tabular}




\section{Housing characteristics}

Housing characteristics includes variables of dwelling type, housing tenure and length of residence in current housing. We also considered variables related to the toll road construction period, such as if the respondent moved to the current house after 2005 and the number of relocations after 2005 .

\section{Psychometric indicators}

Psychometric indicators are used in the latent variable model, explained in the next section. These indicators are based on the satisfaction valuation of the current housing and neighbourhood condition. Each individual replied with a 5-point Likert scale, in which 1 means 'very dissatisfied' and 5 means 'very satisfied' to identify the individual's perception. The valuation includes 14 criteria of housing and neighbourhood criteria that mostly consider by people to select a residential location.

\subsection{Modelling framework}

In this study, we followed the methodology proposed by Walker (2001) and Ben-Akiva et al. (2002) for incorporating latent variables in a discrete choice model with the so-called hybrid choice model (HCM). The methodology requires an integrated model consisting of structural equations of a discrete choice model and a latent variable model and measurement equations for the psychometric indicators. This integrated model will then be estimated simultaneously. By integrating the latent variable model into the discrete choice model, the latent variables can be treated as explanatory variables in the utility functions of the choice model.

\subsubsection{Model structure}

As mentioned earlier, our model consists of a discrete choice model and a latent variable model. The latent variable model includes several variables of socio-demographic, housing and neighbourhood characteristics. To estimate the probability of each alternative of housing, we used a discrete choice model by also incorporating alternatives' attributes and travel-related variables. Figure 4.3 shows the general framework of the hybrid choice model used in this study.

In Figure 4.3, the ellipses represent unobserved (latent) variables, while the rectangles represent observable variables. The latent variables are denoted by $X_{n}^{*}$ for individual $n$. $X_{n}^{*}$ is not an observable variable and should be identified through a set of attitudinal indicators. The latent variable models identify latent constructs as a function of the indicators and capture the causal relationships between explanatory variables and the latent variables. The dashed arrows from the latent variable to the indicators are the measurement models. The indicators are only used to estimate the latent variables and will not be used in the choice model. On the other hand, the estimated latent variables will be treated as explanatory variables in the utility function of choice alternatives, showed by solid arrows from $X_{n}^{*}$ to the utility. The indicators are identified using factor analysis, as described in Section 4.4.4. 


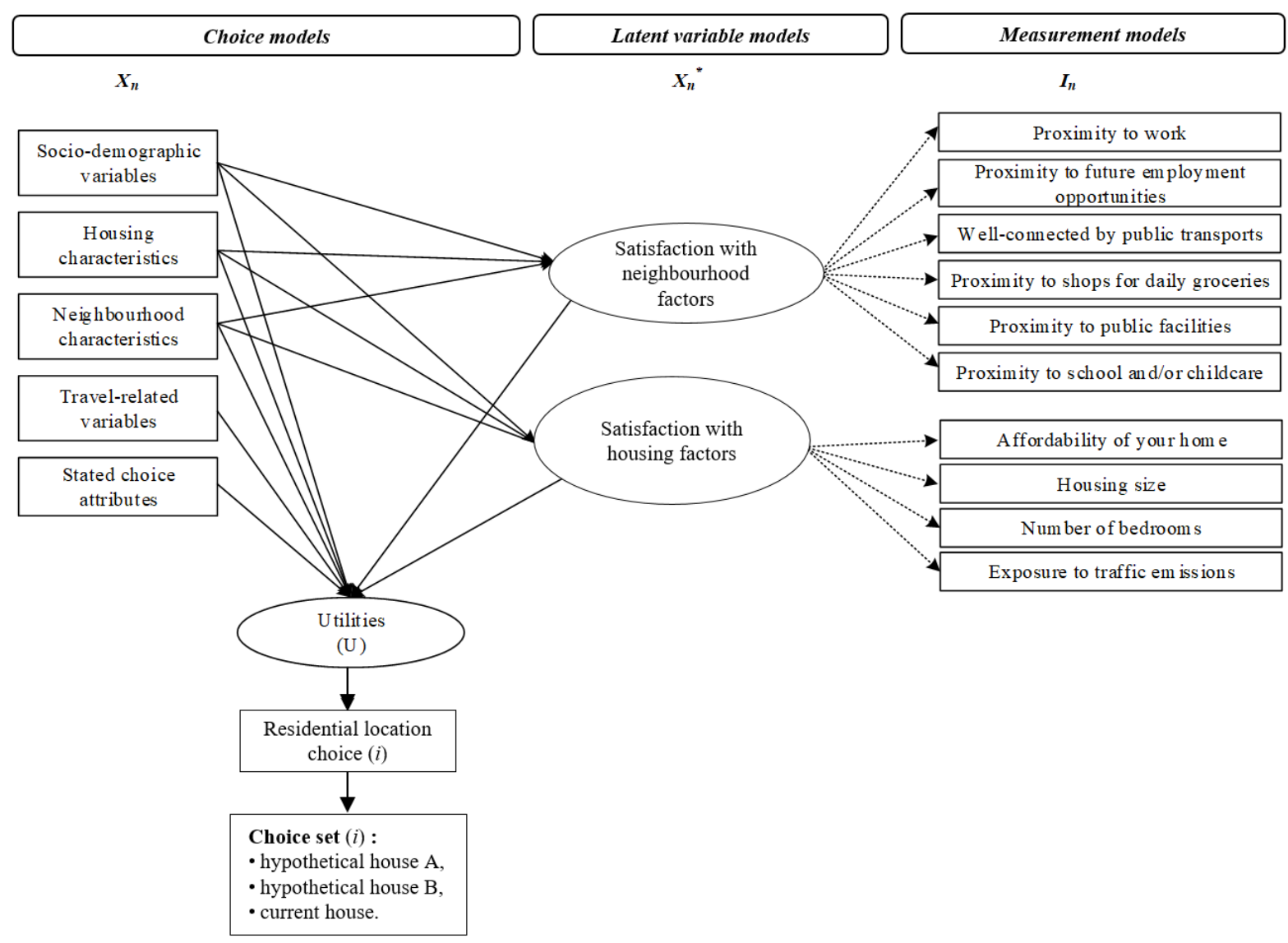

Figure 4.3. General framework of the hybrid choice model

\subsubsection{Model specifications}

For the latent variable model, the distribution of the indicators is conditional on the values of the latent variables $f_{I}\left(I_{n} \mid X_{n}^{*} ; \alpha, \sigma_{v}\right)$. The indicator is given by the formula:

$$
I_{n}=m\left(X_{n}^{*} ; \alpha\right)+\mathrm{v}_{n}
$$

This results in one equation for each indicator. The indicator $I_{n}$ of the latent variable $X_{n}^{*}$; is estimated through parameter $\alpha$, that needs to be estimated, and $v_{n}$ is the error term.

For the latent variable model, the distribution of the latent variables is given the observed variables $X_{n}, f_{L V}\left(X_{n}^{*} \mid X_{n} ; \lambda, \sigma_{\omega}\right)$. The latent variable is given by the formula:

$$
X_{n}^{*}=h\left(X_{n} ; \lambda\right)+\omega_{n}
$$

In this case, there are two latent variables $\left(X_{n}^{*}\right)$, (1) satisfaction with neighbourhood factors $\left(X_{n}^{1}\right)$ and (2) satisfaction with the housing factors $\left(X_{n}^{2}\right) . \lambda$ is the unknown parameter to be estimated and $\omega$ is the random disturbance term, with variance $\sigma_{\omega}$. Here, $X_{n}$ is the explanatory variable related to the psychometric indicators.

For the choice model, the distribution of utilities is needed, $f_{c}\left(U_{n} \mid X_{n}, X_{i}, X_{n}^{*} ; \beta, \sigma_{\varepsilon}\right)$. As shown in Figure 4.1, $X_{n}$ is the generic expression for all explanatory variables, which consists of alternatives' attributes, travel-related variables, neighbourhood characteristics, housing 
characteristics and socio-demographic variables. In general, the choice model is expressed as the following structural equation:

$$
U_{\text {in }}=V\left(X_{n}, X_{i}, X_{n}^{*} ; \beta\right)+\varepsilon_{\text {in }}
$$

$U_{\text {in }}$ is the utility for individual $n$ for alternative $i$. The random utility here is decomposed into systematic utility and a random disturbance. The systematic utility is a function of both observable and latent variables. $\beta$ is a set of parameters to be estimated and $\varepsilon$ is the random disturbance term with variance $\sigma_{\varepsilon}$.

The ordinal model structure was initially tested for the latent variable model. However, given the ranges (5 points-scale) and low variability of the indicators, a continuous structure provided the best model fit and was therefore used in this study. Bahamonde-Birke and Ortúzar (2017) discussed this extensively and found that in the case of low variability of the latent indicators, there was no significant difference in terms of predictability between treating the indicators as continuous or ordinal structures.

\subsubsection{Model estimation}

From Equation (3) and an assumption about the distribution of the disturbance $\varepsilon_{n}$, we derive the choice probability conditional on both observable and latent explanatory variables which can be written as follows:

$$
P\left(i, I_{n} \mid X_{n}, X_{i}, X_{n}^{*} ; \beta, \lambda, \alpha, \sigma_{\varepsilon}, \sigma_{\omega}, \sigma_{\mathrm{v}}\right)=\operatorname{prob}\left\{u_{i n} \geq U_{j n}, \forall \in C_{n}\right\}
$$

$C_{n}$ is the choice set of the individual $\mathrm{n}$. All alternatives are available in our case. Utilities of alternatives are measured as binary variables $y_{i n}$, as given in Equation 4.4.

$$
y_{\text {in }}=\left\{\begin{array}{l}
1, \text { if } U_{\text {in }} \geq U_{j n}, \forall \in C_{n}, \\
0, \text { otherwise. }
\end{array}\right.
$$

The hybrid choice model is composed of choice $i$ and the latent variables. So we have to estimate the joint probability of observing choice $i$ and latent variable, $X_{n}^{*}$. The latent variable model is first estimated using standard latent variable estimators (Equations 4.1 and 4.2). Next, the fitted latent variables and their distributions are used to estimate the choice model, in which the choice probability is integrated over the distribution of the latent variables.

The indicators are introduced in the model as the demonstration of the latent constructs. The addition of indicators improves the accuracy of structural parameters estimation and enables their identification. Assuming that the error components $\left(v_{n}, \omega_{n}, \varepsilon_{n}\right)$ are independent, the joint probability of observing choice $i$ and observable variables $I_{n}$, conditional on explanatory variables $X_{n}$ is:

$$
\begin{gathered}
P\left(i, I_{n} \mid X_{n}, X_{i} ; \beta, \alpha, \lambda, \sigma_{\varepsilon}, \sigma_{v}, \sigma_{\omega}\right) \\
=\int_{X^{*}} P\left(i, I_{n} \mid X_{n}, X_{i}, X_{n}^{*} ; \beta, \sigma_{\varepsilon}\right) f_{I}\left(I_{n} \mid X_{n}^{*} ; \alpha, \sigma_{v}\right) f_{L V}\left(X_{n}^{*} \mid X_{n} ; \lambda, \sigma_{\omega}\right) d X^{*}
\end{gathered}
$$


The model parameters were estimated using maximum likelihood estimation within the software package PythonBiogeme (Bierlaire, 2016). The maximum likelihood can be obtained by maximising the logarithm of the likelihood function over the unknown parameters:

$$
L=\sum_{n} \sum_{i \in C_{n}} y_{i n} \log P\left(i, I_{n} \mid X_{n}, X_{i}, X_{n}^{*} ; \beta, \lambda, \alpha, \sigma_{\varepsilon}, \sigma_{\omega}, \sigma_{\mathrm{v}}\right)
$$

\subsubsection{Factor analysis}

We first performed an exploratory factor analysis on the (psychometric) indicators to construct the latent models. Those indicators represent satisfaction with current housing and neighbourhood characteristics. We extracted factors based on the eigenvalues and selected indicators that have communalities greater than 0.50 . The extraction method was principal component analysis and we used Varimax with Kaiser normalization for the rotation method. Finally, we obtained two factors, which explain $59.28 \%$ of the variance. Table 4.5 lists the factor loadings and the indicators of each factor.

In order to select the proper explanatory variables in the latent model, the model was first estimated as separated latent variable model. This model was later incorporated in the HCM. The indicators manifest the latent variable and the explanatory variables predict those indicators.

Table 4.5. Factor loadings, with significant variables in bold

\begin{tabular}{|l|l|l|}
\hline \multirow{1}{*}{\multicolumn{1}{|c|}{ Indicators }} & \multicolumn{2}{c|}{ Component } \\
\cline { 2 - 3 } & \multicolumn{1}{|c|}{$\begin{array}{c}\text { Factor 1: } \\
\text { Satisfaction with } \\
\text { current } \\
\text { neighbourhood }\end{array}$} & $\begin{array}{c}\text { Factor 2: } \\
\text { Satisfaction with } \\
\text { current housing }\end{array}$ \\
\hline $\begin{array}{l}\text { Distance to work (for myself and/or other household } \\
\text { members) }\end{array}$ & $\mathbf{0 . 7 7 6}$ & 0.230 \\
\hline $\begin{array}{l}\text { Distance to future employment opportunities (for myself } \\
\text { and/or other household members) }\end{array}$ & $\mathbf{0 . 7 8 4}$ & 0.147 \\
\hline Well-connected by public transport & $\mathbf{0 . 6 9 0}$ & 0.289 \\
\hline Distance to shops for daily groceries & $\mathbf{0 . 7 3 2}$ & 0.312 \\
\hline Distance to school and/or childcare & $\mathbf{0 . 6 2 5}$ & 0.293 \\
\hline $\begin{array}{l}\text { Distance to public facilities (clinic / hospital, recreation } \\
\text { area, mosque / church) }\end{array}$ & $\mathbf{0 . 7 3 3}$ & 0.301 \\
\hline Affordability of your home & 0.216 & $\mathbf{0 . 7 1 1}$ \\
\hline Size of your housing (including garden and garage) & 0.283 & $\mathbf{0 . 7 2 5}$ \\
\hline Number of bedrooms & 0.297 & $\mathbf{0 . 6 6 5}$ \\
\hline $\begin{array}{l}\text { Little exposure to traffic emissions (noise and/or } \\
\text { pollution) }\end{array}$ & 0.211 & $\mathbf{0 . 7 8 0}$ \\
\hline
\end{tabular}




\subsection{Results and discussion}

\subsubsection{Estimation result}

This section discusses the findings from the model estimation results. We estimated four models: one mixed logit model (MLM) and three hybrid choice models (HCM). The three HCMs are a model including the latent factor of satisfaction with the current neighbourhood (HCM-LV1), a model including the latent factor of satisfaction with the current housing (HCMLV2) and the combination of the two latent factors (Full-HCM). The upper part of Table 4.6 displays the results of the MLM, including the choice model. The lower part displays the result of the latent variable model, which consists of a structural equation and one measurement equation, followed by the fit measures of each model.

The results show that both observable and latent variables are essential in the decision to relocate and choosing a residential location. Both latent variables have a significant influence on the decision to relocate. We also found that most of the observable factors remain relevant after the addition of the latent factors. The three HCM models show that the latent variables are statistically significant in explaining residential location choice. Moreover, the value of rhosquare-bar shows that the HCM is more robust than the MLM. The Full-HCM also performs better with larger rho-bar values than the other two HCMs. Therefore, we limit the discussion of the choice model in this section to that model. We will first analyse the results from the latent model in the three HCMs and then the results from the choice model.

Table 4.6. Modelling results $(n=9,462)$

\begin{tabular}{|c|c|c|c|c|c|c|c|c|c|c|}
\hline \multirow{2}{*}{ No. } & \multirow{2}{*}{ Name } & \multirow{2}{*}{ Alt. } & \multicolumn{2}{|c|}{ MLM } & \multicolumn{2}{|c|}{ HCM-LV1 } & \multicolumn{2}{|c|}{ HCM-LV2 } & \multicolumn{2}{|c|}{ Full-HCM } \\
\hline & & & Est. & $t$ & Est. & $t$ & Est. & $t$ & Est. & $t$ \\
\hline \multicolumn{11}{|c|}{ Choice Model } \\
\hline 1 & $\mathrm{ASC}_{1}$ & 1 & 4.48 & 11.01 & 0.91 & 0.52 & 0.24 & 0.12 & 0.64 & 0.32 \\
\hline 2 & $\mathrm{ASC}_{2}$ & 2 & 3.56 & 8.47 & 0.21 & 0.12 & -0.51 & -0.24 & -0.28 & -0.14 \\
\hline 3 & $\beta_{\text {cost }}$ & $1,2,3$ & -0.35 & -5.51 & -0.35 & -5.54 & -0.35 & -5.49 & -0.35 & -5.49 \\
\hline 4 & $\beta_{\text {proxy2-5km }}$ & 1 & -0.86 & -8.89 & -0.85 & -8.90 & -0.86 & -8.92 & -0.86 & -8.89 \\
\hline 5 & $\begin{array}{l}\beta_{\text {proxy5- }} \\
10 \mathrm{~km} \text { house }\end{array}$ & 1 & -0.41 & -9.82 & -0.40 & -9.80 & -0.40 & -9.78 & -0.40 & -9.79 \\
\hline 6 & $\beta_{\text {proxy2-5km_house }}$ & 2 & 0.29 & 3.13 & 0.29 & 3.09 & 0.29 & 3.14 & 0.29 & 3.12 \\
\hline 7 & $\begin{array}{l}\beta_{\text {proxy5- }} \\
10 \mathrm{~km} \text { house }\end{array}$ & 2 & -0.24 & -4.65 & -0.24 & -4.64 & -0.24 & -4.61 & -0.24 & -4.65 \\
\hline 8 & $\beta_{\text {proxy } 2}$ & 3 & 0.93 & 4.30 & 0.82 & 3.72 & 0.89 & 4.20 & 0.92 & 4.19 \\
\hline 9 & $\begin{array}{l}\beta_{\text {proxy5- }} \\
10 \mathrm{~km} \_ \text {houseC }\end{array}$ & 3 & -0.42 & -3.59 & -0.42 & 3 & 44 & 54 & -0.42 & -3.60 \\
\hline 10 & $\beta_{\text {rent_highincome }}$ & 2,3 & 0.11 & 2.81 & 0.05 & 2.91 & 0.05 & 2.87 & 0.05 & 2.81 \\
\hline 11 & $\beta_{\text {time }}$ & $1,2,3$ & -0.37 & -5.13 & -0.37 & -5.11 & -0.37 & -5.13 & -0.37 & -5.07 \\
\hline 12 & $\beta_{\text {gender }}$ & 3 & -0.46 & -2.55 & - & - & - & - & -0.42 & -2.27 \\
\hline 13 & $\beta_{\text {hou }}$ & 3 & 0.17 & 2.27 & 0.14 & 2.09 & 0.20 & 2.90 & 0.16 & 2.44 \\
\hline 14 & $\beta_{\text {mid-ir }}$ & 1,3 & -0.08 & -1.73 & - & - & - & - & -0.09 & -1.77 \\
\hline 15 & $\beta_{\text {low-inc }}$ & 1,3 & -0.31 & -2.25 & - & - & -0.16 & -1.70 & -0.31 & -2.22 \\
\hline 16 & $\beta_{\text {car-user }}$ & 3 & -0.34 & -3.74 & -0.37 & -4.30 & -0.34 & -4.15 & -0.38 & -4.11 \\
\hline 17 & $\beta_{\text {non-choosing }}$ & 3 & 2.78 & 12.16 & -2.83 & -12.33 & -2.77 & -11.82 & -2.83 & -11.90 \\
\hline 18 & $\begin{array}{l}\beta_{\mathrm{LV} \_n e i g h \_s a t i s f a c} \\
\text { tion }\end{array}$ & 3 & - & - & 1.30 & 2.76 & - & - & 1.65 & 7.40 \\
\hline
\end{tabular}




\begin{tabular}{|c|c|c|c|c|c|c|c|c|c|c|}
\hline \multirow{2}{*}{ No. } & \multirow{2}{*}{ Name } & \multirow{2}{*}{ Alt. } & \multicolumn{2}{|c|}{ MLM } & \multicolumn{2}{|c|}{ HCM-LV1 } & \multicolumn{2}{|c|}{ HCM-LV2 } & \multicolumn{2}{|c|}{ Full-HCM } \\
\hline & & & Est. & $t$ & Est. & $t$ & Est. & $t$ & Est. & $t$ \\
\hline 19 & $\begin{array}{l}\beta_{\mathrm{LV} \_ \text {house_satisfac- }} \\
\text { tion }\end{array}$ & 3 & - & - & - & - & 1.01 & 1.83 & 1.24 & 2.34 \\
\hline 20 & $\sigma_{\text {sigma_houseA }}$ & 1 & -1.20 & -16.31 & 1.20 & 16.30 & -1.17 & -15.78 & -1.20 & -15.99 \\
\hline 21 & $\sigma_{\text {sigma_house } B}$ & 2 & -0.03 & -0.48 & -0.05 & -0.62 & -0.11 & -1.16 & -0.06 & -0.95 \\
\hline 22 & $\sigma_{\text {sigma_houseC }}$ & 3 & 2.92 & 24.96 & 2.93 & 25.47 & 2.97 & 25.49 & -2.91 & -24.84 \\
\hline \multicolumn{11}{|c|}{ Latent Model } \\
\hline 24 & $\lambda_{\text {intercept1 }}$ & LV1 & - & - & 3.47 & 61.99 & 3.58 & 71.66 & 3.49 & 70.04 \\
\hline 25 & $\lambda_{\text {intercept2 }}$ & LV2 & - & - & - & - & - & - & -2.30 & -2.87 \\
\hline 26 & $\lambda_{\text {bandung }}$ & LV1 & - & - & 0.18 & 3.57 & - & - & 0.18 & 3.50 \\
\hline 27 & $\lambda_{\text {bandung }}$ & LV2 & - & - & - & - & 0.23 & 3.41 & -0.16 & -1.62 \\
\hline 28 & $\lambda_{\text {cimahi }}$ & LV1 & - & - & 0.34 & 8.16 & 0.33 & 6.84 & 0.33 & 7.95 \\
\hline 29 & $\lambda_{\text {cimahi }}$ & LV2 & - & - & - & - & - & - & -0.23 & -2.44 \\
\hline 30 & $\lambda_{\text {purwakarta }}$ & LV1 & - & - & 0.38 & 8.54 & - & - & 0.38 & 9.24 \\
\hline 31 & $\lambda_{\text {purwakarta }}$ & LV2 & - & - & - & - & 0.45 & 10.07 & -0.28 & -2.55 \\
\hline 32 & $\lambda_{\text {proxy }}$ & LV1 & - & - & -0.03 & -5.63 & - & - & -0.03 & -5.69 \\
\hline 33 & $\lambda_{\text {proxy }}$ & LV2 & - & - & - & - & -0.02 & -3.38 & 0.03 & 2.42 \\
\hline 34 & $\lambda_{\text {control }}$ & LV1 & - & - & 0.20 & 4.75 & - & - & 0.20 & 4.76 \\
\hline 35 & $\lambda_{c}$ & LV2 & - & - & - & - & 0.14 & 3.01 & -0.21 & -2.48 \\
\hline 36 & $\lambda_{\text {urban }}$ & LV1 & - & - & 0.07 & 2.09 & - & - & 0.05 & 1.94 \\
\hline 37 & $\lambda_{\text {reslength }}$ & LV2 & - & - & - & - & 0.00 & -2.37 & 0.00 & -3.21 \\
\hline 38 & $\lambda_{\text {detachedhous }}$ & LV2 & - & - & - & - & - & - & 0.09 & 1.79 \\
\hline 39 & $\lambda_{\text {car-owned }}$ & LV1 & - & - & 0.06 & 2.26 & - & - & 0.07 & 3.40 \\
\hline 40 & $\lambda_{\text {PT-user }}$ & LV1 & - & - & 0.10 & 2.28 & - & - & 0.07 & 1.88 \\
\hline 41 & $\lambda_{\text {freq-user }}$ & LV1 & - & - & -0.19 & -4.78 & - & - & -0.19 & -5.45 \\
\hline 42 & $\lambda_{\text {comn }}$ & LV1 & - & - & 0.10 & 2.67 & - & - & 0.09 & 3.03 \\
\hline 43 & $\lambda_{\text {entre }}$ & LV1 & - & - & 0.17 & 5.87 & - & - & 0.18 & 6.58 \\
\hline 44 & $\lambda_{\text {employe }}$ & LV2 & - & - & - & - & - & - & 0.17 & 3.66 \\
\hline 45 & $\sigma_{\text {acc_work }}$ & LV1 & - & - & -0.30 & -15.62 & - & - & -0.30 & $\begin{array}{l}-15.62 \\
\end{array}$ \\
\hline 46 & $\alpha_{\text {acc_employ }}$ & LV1 & - & - & 0.05 & 2.57 & - & - & 0.05 & 2.57 \\
\hline 47 & $\sigma_{\text {acc_employ }}$ & LV1 & - & - & -0.21 & -10.02 & - & - & -0.21 & $\begin{array}{l}-10.02 \\
\end{array}$ \\
\hline 48 & $\alpha_{\text {acc_PT }}$ & LV1 & - & - & 0.11 & 5.64 & - & - & 0.11 & 5.64 \\
\hline 49 & $\sigma_{\text {acc_PT }}$ & LV1 & - & - & -0.29 & -12.44 & - & - & -0.29 & -12.40 \\
\hline 50 & $\alpha_{\text {acc_shops }}$ & LV1 & - & - & 0.13 & 6.83 & - & - & 0.13 & 6.83 \\
\hline 51 & $\sigma_{\text {acc_shops }}$ & LV1 & - & - & -0.37 & -16.51 & - & - & -0.37 & -16.49 \\
\hline 52 & $\alpha_{\text {acc_facilities }}$ & LV1 & - & - & 0.12 & 6.27 & - & - & 0.12 & 6.27 \\
\hline 53 & $\sigma_{\text {acc_facilities }}$ & LV1 & - & - & -0.27 & -11.58 & - & - & -0.27 & -11.52 \\
\hline 54 & $\alpha_{\text {acc_school }}$ & LV1 & - & - & 0.07 & 3.37 & - & - & 0.07 & 3.37 \\
\hline 55 & $\sigma_{\text {acc_school }}$ & LV1 & - & - & -0.24 & -9.18 & - & - & -0.24 & -9.21 \\
\hline 56 & $\sigma_{\text {affordable }}$ & LV2 & - & - & - & - & -0.15 & -6.08 & -0.17 & -6.79 \\
\hline 57 & $\alpha_{\text {bed }}$ & LV2 & - & - & - & - & -0.03 & -1.41 & -0.03 & -1.41 \\
\hline 58 & $\sigma_{\text {bed }}$ & LV2 & - & - & - & - & -0.31 & -10.89 & -0.32 & -10.91 \\
\hline \multicolumn{3}{|c|}{$\begin{array}{l}\text { Number of estimated } \\
\text { parameters: }\end{array}$} & \multicolumn{2}{|c|}{20} & \multicolumn{2}{|c|}{41} & \multicolumn{2}{|c|}{29} & \multicolumn{2}{|c|}{57} \\
\hline \multicolumn{3}{|c|}{ Final log-likelihood: } & \multicolumn{2}{|c|}{-7670.83} & \multicolumn{2}{|c|}{-18458.69} & \multicolumn{2}{|c|}{-11441.83} & \multicolumn{2}{|c|}{-22146.57} \\
\hline \multicolumn{3}{|c|}{ Rho-square-bar: } & \multicolumn{2}{|l|}{0.260} & \multicolumn{2}{|l|}{0.837} & & & 0.841 & \\
\hline
\end{tabular}




\section{Latent variable models for satisfaction with housing and neighbourhood}

In the Full-HCM, we had two latent variables that were simultaneously estimated: satisfaction with the current housing (LV1) and satisfaction with the current neighbourhood (LV2). The two latent variables are positively associated with choosing the current house. As expected, both latent variables are positively associated with staying in current residence.

The results show that when controlling for both house satisfaction and neighbourhood satisfaction, neighbourhood satisfaction, which is related to accessibility, is more significant than the housing satisfaction in the decision where to locate, in line with Tillema et al. (2010). Furthermore, in the latent variable model of neighbourhood satisfaction, the most significant variables were related to locations.

Several variables were found to be relevant for explaining satisfaction with housing and neighbourhood. For instance, distance to the toll gate has a negative coefficient, indicating that the closer the respondents live to the toll gate, the more satisfied they are with their current neighbourhood. This result is in line with the results of the study of Hamersma, Tillema, Sussman, and Arts (2014), who found that $85 \%$ of Dutch respondents were satisfied with living within $1 \mathrm{~km}$ of a highway. However, respondents in the Jakarta-Bandung region are less satisfied with the current housing conditions if they live close to the toll gate.

Furthermore, we found that respondents who reside in Bandung, Purwakarta and Cimahi are quite satisfied with their current neighbourhood. We also found that a variable representing Purwakarta has greater power than similar variables to explain satisfaction with the current neighbourhood. This may be explained by the fact that Purwakarta is relatively close to a section of the Cipularang toll road.

Respondents who live in urban areas are also satisfied with the neighbourhood of their current residence, as there is a wide range of activities that can be accessed easily in urban areas. In contrast, respondents who live $5 \mathrm{~km}$ away or more from the toll gate (in control areas) are quite satisfied with their neighbourhood, although not with their housing. Length of residence is negatively proportional to satisfaction with the current housing; the longer they reside, the less satisfied they are. Respondents who live in a detached house tend to be satisfied with their current housing, although it is only significant at the $90 \%$ confidence interval.

\section{Discrete choice model for residential location choice}

Our respondents valued travel time and travel cost negatively (with values of -0.37 and -0.35 , respectively), but not the product between parameters of 'high-income' and the log of 'rent or land tax' (0.05). It can be interpreted as high-income people are willing to pay higher rent or land tax. Furthermore, residential locations between 2 and $5 \mathrm{~km}$ distance to the toll gates are preferred by the respondents (except in the first alternative) and locations between 5 and $10 \mathrm{~km}$ are less preferred.

Several socio-demographic variables also significantly influence the decision to relocate, such as income, gender and household size. Low-income people have a greater tendency to relocate (value of -0.31), compared with their better-off counterparts. Car users were also found to favour their current houses, with a negative estimated coefficient (-0.38), as they can reach any destination with their own mode of transport. Female respondents are more likely to stay in their current residence. 
Similar to the findings of Pieters and Zondag (2005) and Kim et al. (2005), we also found that households with more family members in the house have a greater tendency to change their residential location. We also identified non-choosing behaviour, i.e. respondents who choose the same alternative in each choice card tended to prefer their current house. This finding might indicate a status quo bias, well known in consumer choice literature. However, this result might also not stem from a real preference for the current situation, but from the fact that some people prefer to leave things unchanged, just because they are unable to select a better alternative in the choice experiment (this is also reported in, e.g. Roson, 2001)

\section{Residential location choice model by distance segments}

We hypothesised that the influence of the toll road decreases with increasing distance from the toll gate. With that in mind, we also simulated four buffer areas based on distance to the toll gate of current residence: less than $2 \mathrm{~km}$, between 2 and $5 \mathrm{~km}$, between 5 and $10 \mathrm{~km}$ and more than $10 \mathrm{~km}$, using the same variables as the Full-HCM. Significant estimated coefficients of each distance segment showed in Table 4.7. Based on the value of rho-square-bar, the four models exhibit almost similar explanatory power. However, the values of both AIC and BIC in each model showed that the model with a $10 \mathrm{~km}$ buffer has the best performance and clearer patterns than others.

Table 4.7. Model estimations for segments of distance to the toll gates

\begin{tabular}{|c|c|c|c|c|c|c|c|c|c|c|}
\hline \multirow{3}{*}{ No. } & \multirow{3}{*}{ Variable } & \multirow{3}{*}{ Alt.* } & \multicolumn{8}{|c|}{ Distance } \\
\hline & & & \multicolumn{2}{|c|}{$<2 \mathrm{~km}(\mathrm{a})$} & \multicolumn{2}{|c|}{$2-5 \mathrm{~km} \mathrm{(b)}$} & \multicolumn{2}{|c|}{$5-10 \mathrm{~km}(\mathrm{c})$} & \multicolumn{2}{|c|}{$>10 \mathrm{~km}(\mathrm{~d})$} \\
\hline & & & Est. & $t$ & Est. & $t$ & Est. & $t$ & Est. & $t$ \\
\hline \multicolumn{11}{|c|}{ Choice Model } \\
\hline 1 & $\mathrm{ASC}_{1}$ & 1 & $17.20^{\mathrm{bc}}$ & 5.13 & $\begin{array}{l}- \\
33.20^{\mathrm{ac}} \\
\mathrm{d}\end{array}$ & -6.40 & $\begin{array}{l}18.10 \\
\text { cbd }\end{array}$ & 6.25 & $8.46^{\mathrm{cb}}$ & 1.35 \\
\hline 2 & $\mathrm{ASC}_{2}$ & 2 & $15.60^{\mathrm{b}}$ & 4.68 & $\begin{array}{l}- \\
33.60^{\mathrm{ac}} \\
\mathrm{d}\end{array}$ & -6.48 & $\begin{array}{l}17.30 \\
\text { bd }\end{array}$ & 5.98 & $7.20^{\mathrm{cb}}$ & 1.15 \\
\hline 3 & $\beta_{\text {cost }}$ & $1,2,3$ & $-0.65^{\mathrm{d}}$ & -4.94 & $-0.54^{\mathrm{d}}$ & -4.96 & -0.18 & -1.61 & - & - \\
\hline 4 & $\beta_{\text {proxy2-5km_houseA }}$ & 1 & $-0.76^{\text {bd }}$ & -4.73 & $-1.44^{\mathrm{a}}$ & -8.55 & -0.19 & -3.59 & -1.32 & -6.05 \\
\hline 5 & $\beta_{\text {proxy5-10km_houseA }}$ & 1 & $-0.75^{b d}$ & -8.17 & $-0.28^{\mathrm{a}}$ & -4.29 & -0.55 & -6.02 & -0.42 & -5.38 \\
\hline 6 & $\beta_{\text {proxy2-5km_houseB }}$ & 2 & $1.06^{\mathrm{bcd}}$ & 5.83 & - & - & - & - & - & - \\
\hline 7 & $\beta_{\text {rent_highincome }}$ & $1,2,3$ & - & - & $0.10^{\text {acd }}$ & 3.37 & - & - & - & - \\
\hline 8 & $\beta_{\text {time }}$ & $1,2,3$ & $-0.49^{\mathrm{d}}$ & -2.78 & $-0.96^{\mathrm{d}}$ & -5.45 & $-0.23^{\mathrm{d}}$ & -2.42 & - & - \\
\hline 9 & $\beta_{\text {housemember }}$ & 3 & - & - & - & - & $0.41^{\mathrm{d}}$ & 3.02 & - & - \\
\hline 10 & $\beta_{\text {mid-income }}$ & 1,3 & $-0.19^{b d}$ & -3.05 & - & - & -0.18 & -1.73 & - & - \\
\hline 11 & $\beta_{\text {low-income }}$ & 1,3 & $-0.38^{\mathrm{d}}$ & -1.67 & - & - & $-0.75^{\mathrm{d}}$ & -2.65 & - & - \\
\hline 12 & $\beta_{\text {car-user }}$ & 3 & $-0.32^{\mathrm{d}}$ & -3.87 & $-0.58^{\mathrm{d}}$ & -2.08 & $-0.50^{\mathrm{d}}$ & -2.66 & - & - \\
\hline 13 & $\beta_{\text {non-choosing }}$ & 3 & $-1.63^{b c}$ & -4.04 & $-4.37^{\mathrm{ac}}$ & $\begin{array}{l}- \\
11.91\end{array}$ & - & - & -2.37 & -3.41 \\
\hline 14 & $\beta_{\text {LV_house_satisfaction }}$ & 3 & $5.31^{\mathrm{b}}$ & 6.39 & $-6.65^{\mathrm{ad}}$ & -4.99 & 4.19 & 5.53 & $3.03^{\mathrm{b}}$ & 1.74 \\
\hline 15 & $\sigma_{\text {sigma_house } A}$ & 1 & $1.04^{\mathrm{b}}$ & 5.94 & $-1.28^{\mathrm{a}}$ & -8.51 & 1.01 & 8.72 & 1.46 & 7.82 \\
\hline 16 & $\sigma_{\text {sigma_houseB }}$ & 2 & $-0.02^{\mathrm{d}}$ & -0.49 & -0.31 & -1.29 & 0.04 & 0.48 & 0.25 & 2.19 \\
\hline 17 & $\sigma_{\text {sigma_ houseC }}$ & 3 & $1.63^{\text {bd }}$ & 10.31 & $3.15^{\mathrm{a}}$ & 16.12 & -2.72 & $\begin{array}{l}- \\
12.68\end{array}$ & 3.55 & 9.04 \\
\hline \multicolumn{11}{|c|}{ Latent Model } \\
\hline 18 & $\lambda_{\text {intercept1 }}$ & LV1 & $3.75^{\mathrm{bd}}$ & 87.98 & $4.00^{\mathrm{ad}}$ & 36.25 & 2.06 & 6.23 & $-0.88^{b}$ & -2.22 \\
\hline 19 & $\lambda_{\text {intercept2 }}$ & LV2 & $3.81^{\mathrm{bd}}$ & 61.08 & $3.61^{\mathrm{a}}$ & 71.08 & 3.27 & 65.99 & 2.06 & 5.29 \\
\hline 20 & $\lambda_{\text {bandung }}$ & LV1 & - & - & - & - & $1.29^{\mathrm{d}}$ & 6.99 & - & - \\
\hline 21 & $\lambda_{\text {bandung }}$ & LV2 & $-0.24^{\mathrm{bd}}$ & -5.90 & - & - & $0.98^{\mathrm{d}}$ & 9.97 & - & - \\
\hline 22 & $\lambda_{\text {cimahi }}$ & LV1 & - & - & $0.32^{\mathrm{ad}}$ & 6.03 & $0.73^{\mathrm{d}}$ & 4.50 & - & - \\
\hline
\end{tabular}




\begin{tabular}{|c|c|c|c|c|c|c|c|c|c|c|}
\hline \multirow{3}{*}{ No. } & \multirow{3}{*}{ Variable } & \multirow{3}{*}{ Alt.* } & \multicolumn{8}{|c|}{ Distance } \\
\hline & & & \multicolumn{2}{|c|}{$<2 \mathrm{~km}$ (a) } & \multicolumn{2}{|c|}{$2-5 \mathrm{~km}(\mathrm{~b})$} & \multicolumn{2}{|c|}{$5-10 \mathrm{~km}(\mathrm{c})$} & \multicolumn{2}{|c|}{$>10 \mathrm{~km}(\mathrm{~d})$} \\
\hline & & & Est. & $t$ & Est. & $t$ & Est. & $t$ & Est. & $t$ \\
\hline 23 & $\lambda_{\text {cimahi }}$ & LV2 & - & - & - & - & 0.21 & 1.73 & - & 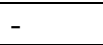 \\
\hline 24 & $\lambda_{\text {purwakarta }}$ & LV1 & $-0.50^{\text {bd }}$ & -9.18 & $0.60^{\mathrm{a}}$ & 10.47 & 0.92 & 9.96 & 0.37 & 5.32 \\
\hline 25 & $\lambda_{\text {purwakarta }}$ & LV2 & $-1.05^{\text {bd }}$ & -14.94 & - & - & $0.72^{\mathrm{d}}$ & 9.69 & & \\
\hline 26 & $\lambda_{\text {proxy }}$ & LV1 & - & - & $-0.20^{\mathrm{a}}$ & -6.70 & 0.11 & 2.83 & $0.27^{\mathrm{a}}$ & 9.44 \\
\hline 27 & $\lambda_{\text {proxy }}$ & LV2 & - & - & - & - & - & - & $0.13^{\mathrm{a}}$ & 4.04 \\
\hline 28 & $\lambda_{\text {control }}$ & LV1 & - & - & $0.39^{\text {acd }}$ & 5.60 & - & - & $0.25^{\mathrm{ab}}$ & 4.30 \\
\hline 29 & $\lambda_{\text {control }}$ & LV2 & - & - & $-0.22^{\mathrm{ac}}$ & -2.64 & - & - & - & - \\
\hline 30 & $\lambda_{\text {urban }}$ & LV1 & - & - & $0.11^{\mathrm{ac}}$ & 2.47 & - & - & $1.11^{\mathrm{a}}$ & 10.85 \\
\hline 31 & $\lambda_{\text {reslength }}$ & LV2 & - & - & - & - & $-0.01^{\mathrm{d}}$ & -2.47 & - & - \\
\hline 32 & $\lambda_{\text {detachedhouse }}$ & LV2 & $0.10^{\mathrm{b}}$ & 1.68 & $0.29^{\mathrm{acd}}$ & 5.44 & - & - & - & - \\
\hline 33 & $\lambda_{\text {car-owned }}$ & LV1 & - & - & - & - & - & - & - & - \\
\hline 34 & $\lambda_{\text {PT_user }}$ & LV1 & $0.24^{\mathrm{bcd}}$ & 3.76 & - & - & - & - & - & - \\
\hline 35 & $\lambda_{\text {freq-user }}$ & LV1 & - & - & - & - & - & - & $-0.16^{\mathrm{a}}$ & -2.12 \\
\hline 36 & $\lambda_{\text {entrepreneur }}$ & LV1 & $0.20^{\mathrm{cd}}$ & 4.01 & $0.10^{\text {cd }}$ & 2.31 & - & - & - & - \\
\hline 37 & $\sigma_{\text {acc_work }}$ & LV1 & $-0.56^{b}$ & -12.94 & $-0.32^{\mathrm{a}}$ & $\overline{1} 10.91$ & -0.27 & -7.59 & -0.49 & -8.21 \\
\hline 38 & $\alpha_{\text {acc_employ }}$ & LV1 & -0.01 & -0.16 & 0.00 & -0.10 & 0.12 & 3.66 & 0.11 & 2.49 \\
\hline 39 & $\sigma_{\text {acc_employ }}$ & LV1 & $-0.33^{b}$ & -8.72 & $-0.21^{\mathrm{a}}$ & -4.69 & -0.19 & -5.83 & -0.37 & -5.68 \\
\hline 40 & $\alpha_{\text {acc_PT }}$ & LV1 & $0.02^{\mathrm{b}}$ & 0.45 & $0.13^{\mathrm{a}}$ & 3.79 & 0.14 & 4.21 & 0.10 & 2.12 \\
\hline 41 & $\sigma_{\text {acc_PT }}$ & LV1 & $-0.52^{\mathrm{b}}$ & -12.72 & $-0.28^{\mathrm{a}}$ & -5.51 & -0.26 & -7.00 & -0.46 & -10.78 \\
\hline 42 & $\alpha_{\text {acc_shops }}$ & LV1 & $0.02^{\mathrm{b}}$ & 0.43 & $0.16^{\mathrm{a}}$ & 4.94 & 0.18 & 5.26 & 0.08 & 1.85 \\
\hline 43 & $\sigma_{\text {acc_shops }}$ & LV1 & $-0.65^{b}$ & -14.73 & $-0.38^{\mathrm{a}}$ & -7.79 & -0.34 & -9.41 & $-0.51^{\mathrm{a}}$ & -11.93 \\
\hline 44 & $\alpha_{\text {acc_facilities }}$ & LV1 & $0.00^{\mathrm{b}}$ & 0.09 & $0.11^{\mathrm{a}}$ & 3.14 & 0.20 & 5.53 & $0.16^{\mathrm{a}}$ & 3.61 \\
\hline 45 & $\sigma_{\text {acc_facilities }}$ & LV1 & $-0.55^{b}$ & -11.54 & $-0.26^{\mathrm{a}}$ & -4.97 & -0.22 & -6.71 & -0.49 & -12.42 \\
\hline 46 & $\alpha_{\text {acc_school }}$ & LV1 & $-0.09^{\mathrm{b}}$ & -2.02 & $0.09^{\mathrm{a}}$ & 2.55 & 0.14 & 3.46 & $0.11^{\mathrm{a}}$ & 2.46 \\
\hline 47 & $\sigma_{\text {acc_school }}$ & LV1 & $-0.41^{b}$ & -6.44 & $-0.25^{\mathrm{a}}$ & -5.21 & -0.16 & -3.07 & -0.48 & -12.62 \\
\hline 48 & $\sigma_{\text {affordable }}$ & LV2 & $-0.21^{\mathrm{b}}$ & -4.16 & $-0.10^{\mathrm{a}}$ & -2.16 & -0.26 & -5.39 & -0.26 & -4.46 \\
\hline 49 & $\alpha_{\text {bed }}$ & LV2 & 0.00 & 0.06 & 0.00 & -0.04 & -0.06 & -1.40 & -0.11 & -2.51 \\
\hline 50 & $\sigma_{\text {bed }}$ & LV2 & $-0.51^{\mathrm{b}}$ & -12.07 & $-0.24^{\mathrm{a}}$ & -4.43 & -0.29 & -5.42 & -0.43 & -9.97 \\
\hline \multicolumn{11}{|c|}{ Fit measures } \\
\hline \multicolumn{3}{|c|}{ Number of estimated parameters: } & \multicolumn{2}{|c|}{37} & \multicolumn{2}{|l|}{37} & \multicolumn{2}{|l|}{38} & \multicolumn{2}{|l|}{31} \\
\hline \multirow{2}{*}{\multicolumn{3}{|c|}{$\begin{array}{l}\text { Final log likelihood: } \\
\text { Rho-square-bar: }\end{array}$}} & \multicolumn{2}{|c|}{-3947.24} & \multicolumn{2}{|c|}{-8021.03} & \multicolumn{2}{|c|}{-6180.78} & \multicolumn{2}{|c|}{-3101.40} \\
\hline & & & \multicolumn{2}{|l|}{0.85} & \multicolumn{2}{|l|}{0.85} & \multicolumn{2}{|l|}{0.83} & \multicolumn{2}{|l|}{0.85} \\
\hline \multicolumn{3}{|c|}{$\begin{array}{l}\text { Rho-square-bar: } \\
\text { AIC: }\end{array}$} & 7968.48 & & 16116.0 & & 12437. & & 6264.8 & \\
\hline \multicolumn{3}{|c|}{$\begin{array}{l}\text { AIC: } \\
\text { BIC: }\end{array}$} & 8173.15 & & 16344.7 & & 12659. & & 6428.8 & \\
\hline
\end{tabular}

Notes: *Alt. 1: hypothetical house A; alt. 2: hypothetical house B; and alt. 3: current house

${ }^{a}$ Significant different with similar parameter in the model of distance segment $<2 \mathrm{~km}$

${ }^{\mathrm{b}}$ Significant different with similar parameter in the model of distance segment $2-5 \mathrm{~km}$

${ }^{c}$ Significant different with similar parameter in the model of distance segment $5-10 \mathrm{~km}$

${ }^{\mathrm{d}}$ Significant different with similar parameter in the model of distance segment $>10 \mathrm{~km}$

In Table 4.7, the parameters that are significantly different to its similar parameter in other group are described with notation. Nevertheless, it is important to mention that the significant differences can also be caused when a significant coefficient compared with a zero coefficient in the other model. In this section, the discussion about the estimated parameters is based on these statistically significant different pairs.

The results of the analysis per distance segment (see Table 4.7) confirm the previous result that the respondents favour locations 2 to $5 \mathrm{~km}$ to the toll gate. Respondents living in a location less than $2 \mathrm{~km}$ from the toll gate preferred houses in locations 2 to $5 \mathrm{~km}$ from the toll gate (a coefficient of 1.06). Respondents with higher incomes also favoured locations within $5 \mathrm{~m}$ 
distance from the toll road and had a higher willingness to pay housing taxes. Interestingly, we found that satisfaction with current housing had a negative effect on people living 2 to $5 \mathrm{~km}$ from the toll gate (with a coefficient of -6.65). This finding is, again, consistent with that of Hamersma et al. (2014), who found that residential satisfaction of Dutch households living within $1 \mathrm{~km}$ of a motorway is high but is influenced by negative perceptions of air pollution, noise and barrier-effect nuisance.

\subsubsection{Model applications}

Estimation of probabilities is usually employed to test the differences between HCM and MLM. Using this test, researchers can investigate the influence of the latent variables on the policy recommendations. A comparison of forecasts from MLM and HCM can be seen, for instance, in the work of Yáñez, Raveau, and Ortúzar (2010) and that of La Paix Puello, Olde-Kalter, and Geurs (2017). Table 4.8 gives the probabilities of each alternative for all samples and several population groups.

We calculated the relative difference in probabilities by segments between the $\mathrm{HCM}^{7}$ and MLM that means before and after including satisfaction with the current housing and neighbourhood effects. We found that, spatial variables significantly affect neighbourhood and housing satisfaction. Furthermore, in general, the probability of remaining in current residence tends to be higher in the HCM than in the MLM.

However, in particular population segments, the addition of latent factors reduces the probability to stay in the current residence. For instance, the average probability for the lowincome segment is lower in the HCM (46.9\%) than in the MLM (48.0\%). It can be interpreted as that low-income people feel less satisfied with their current housing and neighbourhood. Similarly, people who live in the West Bandung regency also feel less satisfied with their current housing and neighbourhood. Compared with other municipalities in this study, West Bandung has the highest percentage of people living in poverty and the lowest gross domestic product (BPS, 2013). These results corroborate the findings of the previous work by Chen, Zhang, Yang, and Yu (2013) that low-income people tend to have lower rate of satisfaction. Also, the addition of latent factors reduced the probability that people who live in non-detached houses remain in their current house, in line with Galster and Hesser (1981).

Moreover, the addition of latent factors reduced the probability of staying in their current residence for people who live more than $10 \mathrm{~km}$ from the toll gate by $1.2 \%$. The reason may be that the average satisfaction with neighbourhood factors in this population segment is the lowest compared with other categories in this variable (3.58 out of 5). On the other hand, the average satisfaction with housing factors is the highest relative to other categories (3.92 out of 5). By living farther away from the toll gate, medium and low-income people can afford a larger house at lower or similar costs. Nevertheless, this also means living further from numerous urban facilities. As we discussed before, high-income people prefer to live closer than $5 \mathrm{~km}$ to the toll road to capture travel time benefits and would like to pay higher land tax, consistent with Shirzadi Babakan and Taleai (2015).

Unlike other population segments, the average probability to remain in the current residence for people who live in the vicinity between 2 to $5 \mathrm{~km}$ from the toll gate is more than $50 \%$, larger

\footnotetext{
${ }^{7}$ Since Full-HCM provides better explanatory power than the other two HCMs, we used this model to estimate the probabilities.
} 
than the total average probability to move. The addition of satisfaction effect turned out decreases the average probability to stay. In contrast with people who live farther away from the toll road gate, people who live in this vicinity tend to pay higher for housing, even though they might enjoy the benefit to be closer to many urban activities, in line with Tillema et al. (2010).

Table 4.8. Average probabilities estimated from HCM and MLM

\begin{tabular}{|c|c|c|c|c|c|c|c|c|c|}
\hline \multirow[b]{2}{*}{ Segment } & \multicolumn{3}{|l|}{ MLM } & \multicolumn{3}{|l|}{$\mathrm{HCM}$} & \multicolumn{3}{|c|}{$\begin{array}{l}\text { Relative Difference } \\
\text { between HCM and MLM }\end{array}$} \\
\hline & $\begin{array}{l}\text { Prob. } \\
\text { house } \\
\text { A }\end{array}$ & $\begin{array}{l}\text { Prob. } \\
\text { house } \\
\text { B }\end{array}$ & $\begin{array}{l}\text { Prob. } \\
\text { current } \\
\text { house }\end{array}$ & $\begin{array}{l}\text { Prob. } \\
\text { house } \\
\text { A }\end{array}$ & $\begin{array}{l}\text { Prob. } \\
\text { house } \\
\text { B }\end{array}$ & $\begin{array}{l}\text { Prob. } \\
\text { current } \\
\text { house }\end{array}$ & $\begin{array}{l}\text { Prob. } \\
\text { house } \\
\text { A }\end{array}$ & $\begin{array}{l}\text { Prob. } \\
\text { house } \\
\text { B }\end{array}$ & $\begin{array}{l}\text { Prob. } \\
\text { current } \\
\text { house }\end{array}$ \\
\hline All sample & $31.0 \%$ & $25.6 \%$ & $43.4 \%$ & $30.5 \%$ & $25.4 \%$ & $44.2 \%$ & $-1.8 \%$ & $-0.9 \%$ & $1.8 \%$ \\
\hline Income: Low & $.6 \%$ & $24.4 \%$ & $.0 \%$ & $28.0 \%$ & $5.2 \%$ & $46.9 \%$ & $1.6 \%$ & $3.0 \%$ & $-2.4 \%$ \\
\hline Mid & $2.3 \%$ & $26.9 \%$ & $.8 \%$ & $31.2 \%$ & $26.2 \%$ & $42.6 \%$ & $-3.4 \%$ & $-2.6 \%$ & $4.4 \%$ \\
\hline High & $33.4 \%$ & $23.2 \%$ & $.4 \%$ & $32.6 \%$ & $22.8 \%$ & $44.6 \%$ & $-2.4 \%$ & $-2.0 \%$ & $2.9 \%$ \\
\hline \multicolumn{7}{|c|}{ Grand total } & $-1.5 \%$ & $-0.6 \%$ & $1.7 \%$ \\
\hline Genc & $.8 \%$ & $27.5 \%$ & $.7 \%$ & $32.0 \%$ & $26.9 \%$ & $41.1 \%$ & $-2.6 \%$ & $-2.0 \%$ & $3.5 \%$ \\
\hline & & $23.8 \%$ & & & $23.8 \%$ & $47.3 \%$ & $-0.7 \%$ & $0.2 \%$ & $.4 \%$ \\
\hline \multicolumn{7}{|c|}{ Grand total } & $-1.7 \%$ & $-0.9 \%$ & $.0 \%$ \\
\hline $\begin{array}{l}\text { Distan } \\
\text { toll ro } \\
<2 \mathrm{~km}\end{array}$ & $\%$ & $27.3 \%$ & $\%$ & $\%$ & $1 \%$ & $\%$ & $-3.8 \%$ & $-3.2 \%$ & $.5 \%$ \\
\hline $2-5$ & $7 \%$ & $.8 \%$ & $5 \%$ & $\%$ & $.4 \%$ & $54.6 \%$ & $1.1 \%$ & $3.3 \%$ & $-1.7 \%$ \\
\hline $5-1$ & $7 \%$ & $32.4 \%$ & $9 \%$ & $36.1 \%$ & $31.0 \%$ & $32.9 \%$ & $-4.4 \%$ & $-4.2 \%$ & $10.1 \%$ \\
\hline$>1$ & $31.0 \%$ & $25.8 \%$ & $43.2 \%$ & $31.1 \%$ & $26.2 \%$ & $42.7 \%$ & $0.3 \%$ & $1.7 \%$ & $-1.2 \%$ \\
\hline \multicolumn{7}{|c|}{ Grand total } & $-1.7 \%$ & $-0.6 \%$ & $3.2 \%$ \\
\hline $\begin{array}{l}\text { Muni } \\
\text { Band }\end{array}$ & $34.7 \%$ & $28.3 \%$ & $37.0 \%$ & $33.2 \%$ & $27.3 \%$ & $39.5 \%$ & $-4.2 \%$ & $-3.5 \%$ & $6.6 \%$ \\
\hline & & 070 & & & $\%$ & & $2.9 \%$ & $-2.6 \%$ & $3.5 \%$ \\
\hline & & $4 \%$ & & & $.1 \%$ & & $-5.0 \%$ & $-4.7 \%$ & $7.2 \%$ \\
\hline West $\mathrm{F}$ & $27.6 \%$ & $23.1 \%$ & $49.3 \%$ & $28.9 \%$ & $24.6 \%$ & $46.5 \%$ & $4.8 \%$ & $6.6 \%$ & $-5.8 \%$ \\
\hline \multicolumn{7}{|c|}{ Grand total } & $-1.8 \%$ & $-1.0 \%$ & $2.9 \%$ \\
\hline Area: & $5 \%$ & $26.2 \%$ & $3 \%$ & $30.9 \%$ & $26.0 \%$ & $43.1 \%$ & $-1.9 \%$ & $-1.0 \%$ & $2.0 \%$ \\
\hline Rural & $29.7 \%$ & $24.0 \%$ & $46.3 \%$ & $29.1 \%$ & $23.8 \%$ & $47.0 \%$ & $-1.8 \%$ & $-0.7 \%$ & $1.5 \%$ \\
\hline \multicolumn{7}{|c|}{ Grand total } & $-1.8 \%$ & $-0.8 \%$ & $1.8 \%$ \\
\hline $\begin{array}{l}\text { Hous } \\
\text { Deta }\end{array}$ & $31.6 \%$ & 26 & $42.4 \%$ & 3 & 25 & $43.8 \%$ & $-2.7 \%$ & 6 & $3.2 \%$ \\
\hline Non-detached & $29.0 \%$ & $24.5 \%$ & $46.5 \%$ & $29.4 \%$ & $25.1 \%$ & $45.5 \%$ & $1.2 \%$ & $2.7 \%$ & $-2.1 \%$ \\
\hline \multicolumn{7}{|c|}{ Grand total } & $-0.8 \%$ & $0.4 \%$ & $0.5 \%$ \\
\hline
\end{tabular}

\subsection{Conclusions}

This study examined the influence of the Cipularang toll road and latent variables in the JakartaBandung region on residential location choice. Four choice models have been developed, of which three included latent variables (hybrid choice models). Four models of distance to the toll gate were also estimated. The main conclusions are as follows.

Our analysis firstly shows that toll roads affect residential location choice and the influence varies with the distance to the toll gate, as well as among population groups in various income groups, municipalities and housing types. People in high-income segments are willing to pay 
higher land taxes to live closer than $5 \mathrm{~km}$ to the toll road to capture travel time benefits, whereas other income segments prefer to live beyond $10 \mathrm{~km}$ from the toll gate where housing costs tend to be low.

Secondly, latent variables of satisfaction with current housing and neighbourhood significantly influence the impact of the toll road on residential location choice. Variation in satisfaction with the current housing and neighbourhood significantly affects the housing choices. The addition of satisfaction with current housing and neighbourhood will increase the probability to stay in current residence, on the exception for low-income individuals. Respondents in the JakartaBandung region tend to be more satisfied with their neighbourhood if they live close to the toll gate. To the contrary, people are less satisfied with their housing size and affordability if they live closer to the toll gate. Omitting satisfaction with current housing and neighbourhood would lead to overestimation of the probability to relocate, especially for people who live less than 2 $\mathrm{km}$ and between 5 and $10 \mathrm{~km}$ from the toll gate, as well as for residents of Bandung and Purwakarta. Model estimation also revealed that observable factors remain relevant after the addition of latent factors. The results in the present study demonstrate that the estimation using hybrid choice models with latent variables is superior to that using discrete choice models. Both observable and unobservable factors are important determinants of residential location choice.

There are several directions for further research. Firstly, it would be interesting how perception and attitudinal variables change over time, before, during and after completion of the project. Secondly, the study of a toll road's impact can also be extended to look at variations in people's travel activities and behaviours as the result of the changes in land use. 


\title{
5. Joint estimation of the impacts of toll road on travel behaviour and residential location choice
}

\author{
This chapter is based on: Andani, I.G.A., La Paix Puello, L., \& Geurs, K. (2019). Modelling \\ effects of changes in travel time and costs of toll road usage on choices for residential \\ location, route and travel mode across population segments in the Jakarta-Bandung region, \\ Indonesia. Submitted for publication in Journal of Transportation Research Part A: Policy \\ and Practice.
}

\begin{abstract}
This chapter provides insight into how variations in Level of Service (LoS) of a toll road, socioeconomic attributes and latent factors simultaneously affect residential location, route and mode choices across population segments in the Jakarta - Bandung region in Indonesia. Three discrete choice models were developed based on stated-revealed preference survey on residential location, route and mode choices. Our analysis shows that toll road usage affects both residential location choice and travel behaviour; this influence varies across income groups and used travel mode and also depends on trip characteristics. Overall, the respondents in our survey prefer toll road options, as also shown by positive attitudes towards the toll road, except for low-income respondents and bus users. Furthermore, we found a significant association between residential location preference and route and mode choices for frequent user of the toll road, low-income respondents and residents who live close to toll road. It means that selfselection exists between residential location choice and mode-route choice, and it is linked to the distance to the toll gate and frequency of using the toll road. Furthermore, we found that car users are the most sensitive to increased travel costs and that low-income car users are the most affected with increased travel costs among car users.
\end{abstract}

Keywords: toll road, joint model, route and mode choices, travel behaviour, residential location choice 


\subsection{Introduction}

In many developing countries, such as Malaysia, Thailand and Indonesia, toll is commonly implemented on expressways as a way to fund the infrastructure construction (Johansen, 1989). The implementation of tolls in urban areas has been found to reduce traffic, with some studies finding a decreased number of trips and vehicle per-km driven (de Palma \& Lindsey, 2006; Nielsen, 2004). This chapter aims to gain insight into how variations in Level of Service (LoS) of a toll road, socio-economic attributes and latent factors simultaneously affect residential location, route and mode choices across population segments, in a developing country context. In developing countries, in general, the maximum amount of travel time that people are willing to allocate is greater than in developed countries (Banerjee et al., 2007), and the same applies with regard to travel budget (Bocarejo \& Oviedo, 2012).

In the case of intra-urban travel, various researchers have found that the pricing schemes can be used to influence travel behaviour efficiently. In the medium and long term, people may change their destination locations, such as shopping destinations, and even their residential location. Particularly in Indonesia, the use of toll roads has been proven to increase economic performance in the region traversed by the toll road (Anas, Tamin, Tamin, \& Wibowo, 2017; Ardiyono et al., 2018). Nevertheless, it is not clear how the construction of a toll road affects the travel behaviour of individuals with different socio-economic backgrounds and trip characteristics. As transport in Indonesia is dominated by private travel, e.g. notably motorcycles (Herwangi et al., 2015), and motorcycles are forbidden on most toll roads, toll roads are unlikely to be used on daily trips.

Nevertheless, the implementation of tolls affects travel behaviour, such as changing the time of the trip or reducing the frequency of trips also occur (Nielsen, 2004; Vrtic et al., 2010). The effects may vary depending on the users' socio-economic background or the trip characteristics. For instance, in Stockholm, tolls affect high-income groups and residents in the central parts of the city where the toll is implemented, more as they travel more (Eliasson \& Mattsson, 2006). On the other hand, van Dijk et al. (2015), who examined toll road impacts in Cape Town, found that lower-income people, if necessary, change their usual route to non-tolled roads. Therefore, it is essential to conduct study of toll road impacts on the travel behaviour in the developing country context.

Toll implementation affects mobility patterns differently in the short term, medium term or long term (Tillema, 2007). Nevertheless, daily travel decisions also depend on life events, such as residential location choice, which at the same time conveys self-selection effects. For example, Guo, Feng, and Timmermans (2018) investigated interdependency between residence, job and transport mode using a pivoted choice experiment. They were able to confirm that unobserved heterogeneity exists between residence relocation and mode choice.

Furthermore, Lin, Wang, and Guan (2017) focused on the effects of residential self-selection and residential determination. They did not find any evidence of residential self-selection for urban poor residents in Beijing, who had little freedom to choose where to live. In a case study for Hanoi, Vietnam, Tran, Zhang, Chikaraishi, and Fujiwara (2016) found that self-selection exists across knowledge-intensive workers' choice on residential location and commuting mode, but not for labour-intensive workers. Therefore, this issue is taken into account in this chapter by simultaneously estimating a model for route, mode and residential location choice of toll road users. 
Using the construction of the Cipularang toll road in Indonesia as a case study, we examine the decisions regarding route, mode and residential location associated to the toll road. Although the toll road opened in 2005, no data is available on its impacts on route choice. Therefore, we conducted a stated preference (SP) experiment for route and mode choices, as well as for residential location choice among around 1,600 respondents who live in the vicinity of the toll gates.

This study differs from earlier studies in the context of toll road usage as it looks at its impact across different population groups and trip characteristics. This study extends the work of Vrtic et al. (2010) and Bhat and Guo (2007) with the joint estimation of residential location and travel behaviour to identify self-selection, as well as through the addition of latent variables in the travel behaviour model, which represents the attitude of individuals towards the toll road and the transport mode they use. These variables are unobservable and we expect them to be key factors that characterise the underlying behaviour that leads to route and transport mode selection. It also allows to study the importance of self-selection for different population segments, such as high or low-income, which to the author's knowledge has never been studied in Indonesia context.

The remainder of this chapter is organised as follows. After this introduction, Section 5.2 describes route and choice behaviour modelling related to toll implementation in the literature. Explanation about the case study can be found in Section 5.3. Sections 5.4 and 5.5 described the data and modelling approach in this study, respectively. Section 5.6 explains the model estimation results. Elasticity calculation across population segments is discussed in Section 5.7. Lastly, this chapter concluded with Section 5.8.

\subsection{Travel behaviour and residential relocation due to a toll road construction: literature review}

The literature about the impact of toll roads on either mode choice or route choice is vast (e.g. Knorr, Chmura, \& Schreckenberg, 2014; Lin, Susilo, Shao, \& Liu, 2018; Vrtic et al., 2010; Wang \& Ehrgott, 2013), as is the literature on residential location choice due to toll road construction (e.g. Tillema et al., 2010). Instead of reviewing this literature here, we focus on studies that examined joint route / travel mode and location choices.

\section{Self-selection: a joint model of residential location and travel behaviour}

Long-term life decisions, such as residential relocation can influence changes in travel behaviour and attitudes (De Vos, Ettema, \& Witlox, 2018; Van der Waerden, Borgers, \& Timmermans, 2003). For instance, Handy et al. (2005) observed significant changes in travel mode and car travel distances after housing relocation. On the opposite, people can also choose their residential location based on their travel preferences (Bhat \& Guo, 2007). This association is referred to 'self-selection' where people select themselves into neighbourhood to enable them to travel with their preferred travel mode (Cao et al., 2010; van Wee, 2009).

Many studies have modelled location and travel behaviour simultaneously to identify selfselection process. For example, Bhat and Guo (2007) described that many characteristics are common to both travel behaviour and residential relocation (such as travel attributes or lifestyle). Studies in the US and European cities (for example, De Vos et al., 2018; Ettema \& Nieuwenhuis, 2017; Jarass \& Scheiner, 2018; Pinjari et al., 2011; Salon, 2006) have found that residential self-selection affects travel behaviour (i.e. car ownership, trip frequency, route and mode choice). 
Most studies in this field modelled residential location choice with commute mode (e.g. Anas, 1981; Guo et al., 2018; Lin et al., 2017; Oakil, Ettema, Arentze, \& Timmermans, 2011; Tran et al., 2016). Several other studies also took into account car ownership as a mid-term decision (e.g. Lerman, 1976; Pinjari et al., 2011; Salon, 2006). La Paix Puello (2012) used a joint model to estimate residential location choice and number of trips simultaneously. Furthermore, Paleti, Bhat, and Pendyala (2013) developed a joint model consisting of six choice dimensions: residential location, work location, vehicle ownership, commute distance, commute mode and number of stops on commute trips. They found a substantial presence of self-selection across those choice dimensions.

Some studies found an association between residential location decision and travel behaviour, although it was very specific to transport service (e.g. availability of public transport stops) and land-use density (e.g. number of schools in the neighbourhood) (for instance in Ettema \& Nieuwenhuis, 2017; La Paix Puello, 2012). In this line, it is important to note that location choice and travel behaviour are multidimensional. Location or built environment can be related to accessibility, land use types, network density or block size. Furthermore, travel behaviour can also include route choice, travel mode choice, number of trips, car ownership, time of day, chaining of trips or purpose of trips. It means that, a different selection of location or travel behaviour dimensions could lead to different research results, the so-called issue of 'systematic comparison'(La Paix Puello, 2012).

However, none of these studies, to the author's knowledge, focused on effects of infrastructure changes (e.g. toll roads) on travel behaviour. The importance of analysing these effects is that it helps elucidate the real impact of unobserved attributes on travel demand and, therefore, the estimation of travel revenues. In this study, a joint (simultaneous) model was developed to investigate self-selection effects in residential location, route and mode choices within the context of toll road usage. This can be done through the identification of common random coefficients in both models of residential location and route-mode choice.

\section{Latent factors}

Travel mode and route choices are not merely reflected in the observed explanatory variables. Preferences may vary across individuals regardless of their socio-economic background, such as age, gender, income, etc. To account for this unobserved heterogeneity, various studies have incorporated latent factors to model travel behaviour (e.g. Atasoy, Glerum, \& Bierlaire, 2013; Hurtubia, Atasoy, Glerum, Curchod, \& Bierlaire, 2010; La Paix, Bierlaire, Cherchi, \& Monzón, 2013; Yáñez et al., 2010). By taking latent factors into account, it is possible to capture unobserved heterogeneity and improve the behavioural representation of the traditional discrete choice model (Walker, 2001). Together with observable factors and alternative attributes, latent factors affect individuals' decision-making processes.

Most latent factors included in studies of travel behaviour are attitudes. Attitudes correspond to the characteristics of individuals and reflect their needs, values, tastes and capabilities (Walker, 2001). Some studies incorporated attitudes that related specifically to travel alternatives. For example, Hurtubia et al. (2010) used a latent variable that describes attitudes towards public transport. Yáñez et al. (2010) used perceived reliability, comfort and accessibility in the context of mode choice. Furthermore, Bahamonde-Birke, Kunert, Link, and Ortúzar (2015) estimated three latent variables in the context of interurban travel: comfort, level of stress and reliability. In order to model route and mode choices in the context of a toll road, we also modelled attitudes toward the toll road and people's current travel mode. 


\subsection{Case study context}

The Cipularang toll road connected Jakarta and Bandung, which are two big cities in Indonesia (Figure 5.1). The toll road reduced the travel time between those cities from around 5 hours to around 2 hours. A decade after the toll road's construction, the area along the toll road has experienced urbanisation in which there was an increase in residential land use of up to $2 \%$.

In the case of this toll road, several studies have been conducted on how the toll road benefitted the area economically. For instance, Dorodjatoen (2009) investigated how the intensifying relationship between Bandung and Jakarta with the establishment of the toll road affected Purwakarta, a municipality along the toll road (it has two toll gates). He pointed out that the number of large and medium-sized industry has increased by almost $15 \%$ in the area, stating that the industrial relocation was due to the proximity to Jakarta and cheaper labour in Purwakarta. The growth of new settlement areas could also be observed in Purwakarta, and these new settlements were dominated by people from Bandung and Jakarta. The Cipularang toll road has enabled them to obtain cheaper housing in Purwakarta and commute daily to one of the big cities. In terms of regional economic impact, Anas et al. (2017) concluded that the existence of the toll road benefits Bandung the most, with freight transportation cost reduced significantly and increases in the added value of the processing industry. A significant increase of tourism occurred in Bandung, also boosting the local economy, with increased traffic flows from Jakarta to Bandung, notably during weekends, with a $29 \%$ average increase in tourists arriving at the toll gate in Bandung during 2008-2011 (Adriani, 2013).

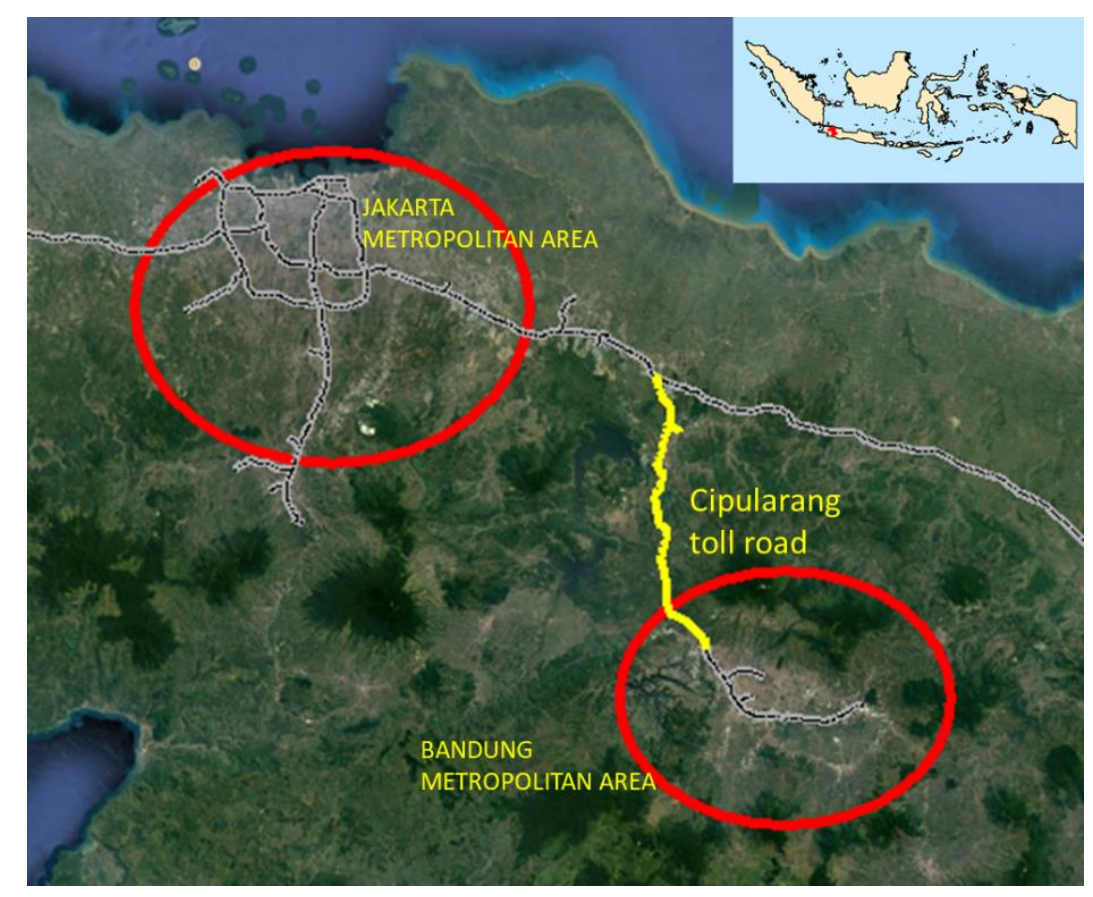

Figure 5.1. Cipularang toll road location in Indonesia 


\subsection{Data}

\subsubsection{Survey design and data collection}

A joint revealed and stated preference survey was conducted in the summer and autumn of 2017 to collect data from 1,622 respondents living in the vicinity of the Cipularang toll road gates. The number of respondents in each municipality was mainly selected on the basis of the amount of residential land use increase and the number of toll gates in target areas. Based on sociodemographic characteristics (see Table 4.1), the sample appears to be representative. The respondents were collected through a door-to-door survey using computer-aided personal interview (CAPI) technology. They were all workers with paid jobs, within the productive age (15-64) and not working from home. Thus, we were able to analyse the trade-offs of travel cost and travel time on a regular basis. Lower-income people were deliberately over-sampled since we expected the effect of toll road costs on this population group to be greater than on other groups.

A stated choice (SC) experiment developed in this study followed a fractional factorial design. The experiment only used a subset of all the possible alternatives, although still permitting orthogonal estimation (Louviere et al., 2000).

\subsubsection{Stated experiment for route and mode choices}

In the survey, eight choice card sets were provided to the respondents. Each card consisted of different values of monetary travel costs and time, pivoted from the real values of the respondent's recent trip via the toll road. Each respondent was asked to choose between four alternatives, which were a combination of route and mode choice: (1) travel via the toll road and use the same mode, (2) travel via the toll road and use a different mode, (3) use the same mode but not travel via the toll road and (4) not travel via the toll road and use a different mode. Opt-out choices, such as preferring another mode (e.g. motorcycle or train) or not to travel, were provided as well. The eight choice cards are not included here, as they were tailor-made for each respondent; Figure 5.2 contains an example.

The values of travel time and cost in each choice card were pivoted to certain levels, adjusted on the basis of the respondents' recent trips using the Cipularang toll road. By pivoting around the RP data, the SC experiment is more realistic and it enables preferences to be expressed in a context that is similar to the actual behaviour of the respondent (Ben-Akiva \& Lerman, 1985; Louviere et al., 2000).

The reason to select these percentages as pivot values relies on the calculation of travel time savings in each district with use of the Cipularang toll road (in Chapter 3). As the survey area covers a wide range of geographical regions, the range of travel times and costs was broad among the respondents. We therefore classed the pivot levels of each attribute into five categories, as shown in Table 5.1. Since the time-savings, in percentage, are slightly different for some regions, the pivot level was rounded upward. Level 1 shows the average travel timesaving percentage, and Level 2 shows the percentage of maximum travel time savings due to the Cipularang Toll Road.

Furthermore, levels of the attribute of travel cost were also pivoted based on the simulation of total travel (out-of-pocket) cost changes related to the Cipularang toll road. It was pivoted to 
four levels that reflect the value of each quartile in the simulation. We further verified that the values in the design would cover significant differences in the RP data.

Choice set $1 / 8$

Suppose you could choose between the options below for your last trip via the Cipularang toll road. Which option do you prefer?

\begin{tabular}{|cc|}
\hline \multicolumn{3}{|c|}{ Same vehicle, via } \\
Cipularang toll road \\
Travel cost (IDR): & $\mathbf{2 8 0 0 0 0}$ \\
Travel time (min): & $\mathbf{1 2 6}$ \\
\hline
\end{tabular}
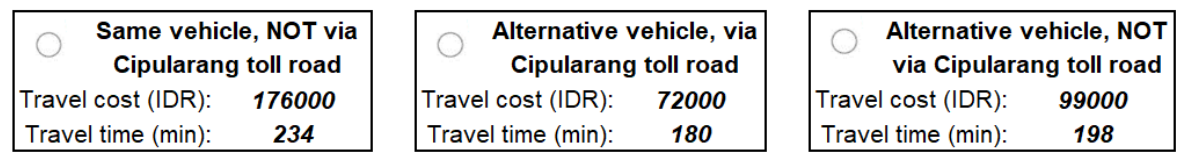

I would prefer other mode (e.g. motorcycle or train)

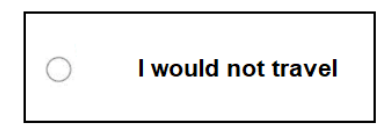

Figure 5.2. Example of the choice card

Table 5.1. Alternatives' attributes of SC experiment of route and mode choices

\begin{tabular}{|c|c|c|c|c|c|c|c|}
\hline \multirow{2}{*}{$\begin{array}{c}\text { Area } \\
\text { category }\end{array}$} & \multirow{2}{*}{ District } & \multicolumn{2}{|c|}{ Travel time } & \multicolumn{4}{|c|}{ Travel cost } \\
\hline & & Level 1 & Level 2 & Level 1 & Level 2 & Level 3 & Level 4 \\
\hline I & $\begin{array}{l}\text { Bungursari, } \\
\text { Jatiluhur, Tegalwaru, } \\
\text { Parongpong, } \\
\text { Sukasari } \\
\text { (Purwakarta) }\end{array}$ & $-5 \%$ & $-15 \%$ & $-5 \%$ & $\begin{array}{c}0 \% \\
\text { (current) }\end{array}$ & $+25 \%$ & $+50 \%$ \\
\hline II & $\begin{array}{l}\text { Ngamprah, Cipatat, } \\
\text { Darangdan, Cililin, } \\
\text { Cihampelas, Plered, } \\
\text { Sukatani }\end{array}$ & $-5 \%$ & $-25 \%$ & $-20 \%$ & $-5 \%$ & $+25 \%$ & $+50 \%$ \\
\hline III & $\begin{array}{ll}\text { Purwakarta, } & \text { Bandung } \\
\text { Kulon, } & \text { Babakan } \\
\text { cikao, } & \text { Cidadap, } \\
\text { Coblong } & \\
\end{array}$ & $-10 \%$ & $-30 \%$ & $-20 \%$ & $-10 \%$ & $+25 \%$ & $+75 \%$ \\
\hline IV & $\begin{array}{lr}\text { Cimahi } & \text { Utara, } \\
\text { Sukasari } & \text { (Bandung } \\
\text { City) } & \end{array}$ & $-10 \%$ & $-40 \%$ & $-30 \%$ & $-15 \%$ & $+25 \%$ & $+100 \%$ \\
\hline V & $\begin{array}{l}\text { Cimahi } \\
\text { Cicendo, } \\
\text { Padalarang }\end{array}$ & $-10 \%$ & $-50 \%$ & $-35 \%$ & $-25 \%$ & $+25 \%$ & $+75 \%$ \\
\hline
\end{tabular}

\subsubsection{Stated choice experiment for residential location choice}

We included four attributes in each choice card: (1) land tax or rent per month, (2) travel (monetary) cost to work, (3) travel time to work and (4) distance to the toll gate. The first three attributes are important factors to influence residential location choice in many studies. While the latter is the focus of this study to indicate the presence of the toll road.

In each choice card, the respondent was asked to choose between hypothetical house A or house $\mathrm{B}$, in which each alternative had different attributes. We also included the current house as the third alternative, in which each attribute was assumed to be the existing condition. 
Table 5.2. Alternatives' attributes for SC experiment of residential location choice

\begin{tabular}{|c|c|c|}
\hline Attribute & Description & Level \\
\hline Rent / land tax & Monthly rent or estimated land tax (in IDR) & \multirow{3}{*}{$\begin{array}{l}-75 \%,-25 \% \\
+25 \%,+75 \%\end{array}$} \\
\hline Travel cost to work & $\begin{array}{l}\text { Total (out-of-pocket) cost for transportation for } \\
\text { a day to work (in IDR) }\end{array}$ & \\
\hline Travel time to work & $\begin{array}{l}\text { Total travel time from the respondent's house to } \\
\text { the workplace }\end{array}$ & \\
\hline \multirow{4}{*}{$\begin{array}{l}\text { Distance to the toll } \\
\text { gate }\end{array}$} & \multirow{4}{*}{$\begin{array}{l}\text { Distance to the toll gate from the centre of the } \\
\text { home district (in } \mathrm{km} \text { ) }\end{array}$} & Less than $2 \mathrm{~km}$ \\
\hline & & $2-5 \mathrm{~km}$ \\
\hline & & $5-10 \mathrm{~km}$ \\
\hline & & More than $10 \mathrm{~km}$ \\
\hline
\end{tabular}

\subsubsection{Descriptive analysis}

In the survey, we collected data about socio-economic characteristics as well as, housing, neighbourhood and travel characteristics to support the stated-choice attributes in explaining residential location and travel behaviour of route and mode choices. Table 5.3 shows the descriptive statistics of the data used in the joint model.

We found non-choosing behaviour in the data, namely 5\% and $21 \%$ in the SC experiments for residential location choice and route-mode choice, respectively. This means that respondents kept choosing the same alternative across the choice sets. The respondents may have found the choice sets quite complex or perhaps they were only familiar (or content) with their current condition and, thus, preferred the same condition. Concerning residential relocation, this might be an extreme decision for some people. They might not find a new house according to their preferences or might not be able to afford it. Omitting those respondents from the sample was found to have no influence on the model fit. We, therefore, included this behaviour as explanatory variable in both models.

Moreover, in order to obtain a reliable dataset, we removed respondents who stated that they relied on the toll road and did not have or know any alternative non-tolled route to reach their destinations. This process resulted in 8,672 observations in our dataset for the joint model.

Table 5.3. Statistics of variables in the joint model of residential location choice and travel behaviour

\begin{tabular}{|l|c|c|c|c|c|c|}
\hline Variables & $\begin{array}{c}\text { Notation } \\
\text { parameter }\end{array}$ & $\mathrm{N}$ & Min. & Max. & Mean & St. dev \\
\hline Stated choice attributes & \multicolumn{7}{|l|}{} & \multicolumn{2}{|c|}{} \\
\hline Travel cost (IDR) & $\gamma_{\text {cost }}$ & 8672 & 4000 & 800000 & 136431 & 123051 \\
\hline Travel time (min) & $\gamma_{\text {time }}$ & 8672 & 10 & 450 & 112 & 78 \\
\hline $\begin{array}{l}\text { Estimated travel cost of } \\
\text { alternative mode (IDR) }\end{array}$ & $\gamma_{\text {cost_othermode }}$ & 8672 & 0 & 800000 & 109960 & 108207 \\
\hline $\begin{array}{l}\text { Non-choosing } \\
\text { behaviour on route- } \\
\text { mode choices }\end{array}$ & $\beta_{\text {non-choosing }}$ & 8672 & 0.00 & 1.00 & 0.05 & 0.22 \\
\hline $\begin{array}{l}\text { Non-choosing } \\
\text { behaviour on }\end{array}$ & $\gamma_{\text {non-choosing }}$ & 8672 & 0.00 & 1.00 & 0.21 & 0.41 \\
\hline
\end{tabular}




\begin{tabular}{|c|c|c|c|c|c|c|}
\hline Variables & $\begin{array}{l}\text { Notation } \\
\text { parameter }\end{array}$ & $\mathrm{N}$ & Min. & Max. & Mean & St. dev \\
\hline \multicolumn{7}{|l|}{$\begin{array}{l}\text { residential location } \\
\text { choice }\end{array}$} \\
\hline \multicolumn{7}{|c|}{ Neighbourhood characteristics } \\
\hline $\begin{array}{l}\text { Distance to toll gate } \\
\text { (euclidian distance in } \\
\mathrm{km} \text { ) }\end{array}$ & $\lambda_{\text {distance }}$ & 8672 & 0.63 & 14.32 & 5.56 & 3.48 \\
\hline Urbanised area & $\lambda_{\text {urban }}$ & 8672 & 0.00 & 1.00 & 0.73 & 0.45 \\
\hline \multicolumn{7}{|l|}{ Municipality: } \\
\hline Bandung & $\lambda_{\text {bandung }}$ & 8672 & 0.00 & 1.00 & 0.09 & 0.28 \\
\hline Purwakarta & $\lambda_{\text {purwakarta }}$ & 8672 & 0.00 & 1.00 & 0.36 & 0.48 \\
\hline Cimahi & $\lambda_{\text {cimahi }}$ & 8672 & 0.00 & 1.00 & 0.16 & 0.37 \\
\hline West Bandung & $\lambda_{\text {westbandung }}$ & 8672 & 0.00 & 1.00 & 0.39 & 0.49 \\
\hline $\begin{array}{l}\text { Control area ( }>5 \mathrm{~km} \\
\text { distance from toll gate) }\end{array}$ & $\lambda_{\text {control }}$ & 8672 & 0.00 & 1.00 & 0.18 & 0.39 \\
\hline \multicolumn{7}{|l|}{ Socio-economic variables } \\
\hline Gender $($ male $=1)$ & $\gamma_{\text {male }}$ & 8672 & 0.00 & 1.00 & 0.48 & 0.50 \\
\hline Age & $\gamma_{\text {age }}$ & 8672 & 18.00 & 75.00 & 36.63 & 11.74 \\
\hline \multicolumn{7}{|l|}{ Income groups: } \\
\hline $\begin{array}{l}\text { Dummy of low- } \\
\text { income (below } \\
\text { minimum wage) }\end{array}$ & $\gamma_{\text {low-income }}$ & 8672 & 0.00 & 1.00 & 0.36 & 0.48 \\
\hline $\begin{array}{l}\text { Dummy of middle- } \\
\text { income (up to } 3 \text { times } \\
\text { minimum wage) }\end{array}$ & $\gamma_{\text {mid-income }}$ & 8672 & 0.00 & 1.00 & 0.54 & 0.50 \\
\hline $\begin{array}{l}\text { Dummy high-income } \\
\text { (more than } 3 \text { times } \\
\text { minimum wage) }\end{array}$ & $\gamma_{\text {high-income }}$ & 8672 & 0.00 & 1.00 & 0.10 & 0.30 \\
\hline $\begin{array}{l}\text { Number of household } \\
\text { size }\end{array}$ & $\gamma_{\text {housemember }}$ & 8672 & 1.00 & 11.00 & 3.36 & 1.25 \\
\hline Dummy of employee & $\lambda_{\text {employee }}$ & 8672 & 0.00 & 1.00 & 0.43 & 0.50 \\
\hline $\begin{array}{l}\text { Dummy of people who } \\
\text { are self-employed }\end{array}$ & $\lambda_{\text {entrepreneur }}$ & 8672 & 0.00 & 1.00 & 0.43 & 0.50 \\
\hline \multicolumn{7}{|l|}{ Housing characteristics } \\
\hline $\begin{array}{l}\text { Dummy of housing } \\
\text { type (detached house) }\end{array}$ & $\lambda_{\text {detached }}$ & 8672 & 0.00 & 1.00 & 0.70 & 0.46 \\
\hline $\begin{array}{l}\text { Length of residence in } \\
\text { current house (years) }\end{array}$ & $\lambda_{\text {length_res }}$ & 8672 & 0.00 & 65.00 & 15.50 & 14.11 \\
\hline \multicolumn{7}{|l|}{ Travel-related variables } \\
\hline \multicolumn{7}{|l|}{$\begin{array}{l}\text { Travel mode on trip via } \\
\text { Cipularang: }\end{array}$} \\
\hline $\begin{array}{l}\text { Car (as driver and } \\
\text { passenger) }\end{array}$ & $\gamma_{\mathrm{car}}$ & 8672 & 0.00 & 1.00 & 0.52 & 0.50 \\
\hline Taxi & $\gamma_{\text {taxi }}$ & 8672 & 0.00 & 1.00 & 0.02 & 0.15 \\
\hline Shuttle service & $\gamma_{\text {shuttle }}$ & 8672 & 0.00 & 1.00 & 0.07 & 0.25 \\
\hline Bus & $\gamma_{\text {bus }}$ & 8672 & 0.00 & 1.00 & 0.39 & 0.49 \\
\hline $\begin{array}{l}\text { Frequent user (travel } \\
\text { via the toll road at least } \\
\text { once a week) }\end{array}$ & $\lambda_{\text {freq-user }}$ & 8672 & 0.00 & 1.00 & 0.61 & 0.49 \\
\hline \multicolumn{7}{|l|}{ Regular mode: } \\
\hline Private car & $\beta_{\text {car-user }}$ & 8672 & 0.00 & 1.00 & 0.10 & 0.30 \\
\hline
\end{tabular}




\begin{tabular}{|l|c|c|c|c|c|c|}
\hline Variables & $\begin{array}{c}\text { Notation } \\
\text { parameter }\end{array}$ & $\mathrm{N}$ & Min. & Max. & Mean & St. dev \\
\hline $\begin{array}{l}\text { Public transport } \\
\text { (including public } \\
\text { transport with certain } \\
\text { routes and without } \\
\text { routes, e.g. taxi) }\end{array}$ & $\lambda_{\text {PT-user }}$ & 8672 & 0.00 & 1.00 & 0.16 & 0.37 \\
\hline Motorcycle & $\lambda_{\text {motorcycle-user }}$ & 8672 & 0.00 & 1.00 & 0.69 & 0.46 \\
\hline $\begin{array}{l}\text { Commuter (travel via } \\
\text { the toll road at least } \\
\text { once a week for work } \\
\text { purpose) }\end{array}$ & $\lambda_{\text {commuter }}$ & 8672 & 0.00 & 1.00 & 0.18 & 0.38 \\
\hline Number of cars owned & $\lambda_{\text {car-owned }}$ & 8672 & 0.00 & 2.00 & 0.29 & 0.54 \\
\hline Work trip & $\gamma_{\text {worktrip }}$ & 8672 & 0.00 & 1.00 & 0.23 & 0.42 \\
\hline Non-work trip & $\gamma_{\text {nonworktrip }}$ & 8672 & 0.00 & 1.00 & 0.75 & 0.43 \\
\hline Work trip - self paid & $\gamma_{\text {worktrip_selfpaid }}$ & 8672 & 0.00 & 1.00 & 0.14 & 0.35 \\
\hline Work trip - other paid & $\gamma_{\text {worktrip_otherpaid }}$ & 8672 & 0.00 & 1.00 & 0.08 & 0.28 \\
\hline
\end{tabular}

Furthermore, psychometric indicators used in the latent variable model are based on the valuation of the travel mode used on the recent trip via the toll road and the toll road itself. Each individual replied to several statements with a 5-point Likert scale, in which 1 means 'strongly disagree' and 5 means 'strongly agree' to identify the individual's perception (see the statistics in Table 5.4 below). Those statements are linked to perceived safety, reliability and comfort, as discussed in Section 5.2 about latent factors. These psychometric indicators were included in the latent variable model.

Table 5.4. Descriptive statistics of the psychometric indicators (evaluation from 1 to 5)

\begin{tabular}{|c|c|c|c|c|c|c|}
\hline Statements & $\begin{array}{l}\text { Notation } \\
\text { parameter }\end{array}$ & $\mathrm{N}$ & Min. & Max. & Mean & St. dev \\
\hline $\begin{array}{l}\text { I do not have to make several } \\
\text { transfers }\end{array}$ & $\alpha_{\text {notransfer }}$ & 8672 & 1.00 & 5.00 & 3.66 & 0.89 \\
\hline $\begin{array}{l}\text { My mode is safer than the } \\
\text { alternative mode }\end{array}$ & $\alpha_{\text {mode_safe }}$ & 8672 & 1.00 & 5.00 & 3.39 & 0.99 \\
\hline $\begin{array}{l}\text { My mode is more comfortable } \\
\text { than the alternative mode }\end{array}$ & $\alpha_{\text {mode_comfortable }}$ & 8672 & 1.00 & 5.00 & 3.40 & 0.97 \\
\hline I do not have to wait long & $\alpha_{\text {mode_waitingtime }}$ & 8672 & 1.00 & 5.00 & 3.69 & 0.88 \\
\hline $\begin{array}{l}\text { There is no/low congestion on } \\
\text { the toll road }\end{array}$ & $\alpha_{\text {toll_nocongestion }}$ & 8672 & 2.00 & 5.00 & 4.27 & 0.52 \\
\hline $\begin{array}{l}\text { Driving on toll road is safer } \\
\text { than on non-toll roads }\end{array}$ & $\alpha_{\text {toll_safe }}$ & 8672 & 2.00 & 5.00 & 4.16 & 0.54 \\
\hline $\begin{array}{l}\text { Traffic signs on toll roads are } \\
\text { complete and very clear }\end{array}$ & $\alpha_{\text {toll_signage }}$ & 8672 & 2.00 & 5.00 & 4.19 & 0.50 \\
\hline $\begin{array}{l}\text { Toll road has better road } \\
\text { surface condition }\end{array}$ & $\alpha_{\text {toll_roadsurface }}$ & 8672 & 1.00 & 5.00 & 4.13 & 0.56 \\
\hline $\begin{array}{l}\text { Easy to reach toll road gate } \\
\text { from my location }\end{array}$ & $\alpha_{\text {toll_reachable }}$ & 8672 & 1.00 & 5.00 & 4.13 & 0.51 \\
\hline
\end{tabular}


In contrast with toll road operation in Europe, which is dominated by commuter traffic, the Cipularang toll road traffic in Indonesia is dominated by leisure trips, which we also found in our survey. Leisure trips took up $73 \%$. Furthermore, we found that mode use on the toll road was dominated by car at $50 \%$, followed by bus at $40 \%$. However, in daily life, commuting was dominated by motorcycle use at $72 \%$ (see Table 5.5), which is in line with several earlier studies in Indonesia (Herwangi et al., 2015; Susilo et al., 2007). As is visible in Table 5.6, low-income respondents also used the car as to travel via the toll road, taking up second place (at 39\%) after the bus (49\%). Low-income respondents were found to use the toll road rarely; only $15 \%$ of them travel via the toll road at least once a week.

Table 5.5. Cross tabulation of mode used on the toll road and commuting mode

\begin{tabular}{|c|c|c|c|c|c|}
\hline \multirow[b]{2}{*}{ Mode used on the toll road } & \multicolumn{4}{|c|}{ Commuting mode } & \multirow[b]{2}{*}{ Total } \\
\hline & $\begin{array}{l}\text { Private } \\
\text { motor- } \\
\text { cycle }\end{array}$ & $\begin{array}{c}\text { Private } \\
\text { car }\end{array}$ & $\begin{array}{l}\text { Public } \\
\text { transport }\end{array}$ & Other & \\
\hline Private car & 578 & 126 & 76 & 26 & 806 \\
\hline$\%$ in mode used on the toll road & $71.7 \%$ & $15.6 \%$ & $9.4 \%$ & $3.2 \%$ & $100.0 \%$ \\
\hline$\%$ in commuting mode & $49.8 \%$ & $93.3 \%$ & $31.0 \%$ & $31.7 \%$ & $50.0 \%$ \\
\hline Taxi & 26 & 4 & 5 & 1 & 36 \\
\hline$\%$ in mode used on the toll road & $72.2 \%$ & $11.1 \%$ & $13.9 \%$ & $2.8 \%$ & $100.0 \%$ \\
\hline$\%$ in commuting mode & $2.2 \%$ & $3.0 \%$ & $2.0 \%$ & $1.2 \%$ & $2.2 \%$ \\
\hline Shuttle service & 111 & 1 & 17 & 8 & 137 \\
\hline$\%$ in mode used on the toll road & $81.0 \%$ & $0.7 \%$ & $12.4 \%$ & $5.8 \%$ & $100.0 \%$ \\
\hline \% in commuting mode & $9.6 \%$ & $0.7 \%$ & $6.9 \%$ & $9.8 \%$ & $8.4 \%$ \\
\hline Bus & 445 & 4 & 147 & 47 & 643 \\
\hline$\%$ in mode used on the toll road & $69.2 \%$ & $0.6 \%$ & $22.9 \%$ & $7.3 \%$ & $100.0 \%$ \\
\hline$\%$ in commuting mode & $38.4 \%$ & $3.0 \%$ & $60.0 \%$ & $57.3 \%$ & $39.6 \%$ \\
\hline Total & 1160 & 135 & 245 & 82 & 1622 \\
\hline$\%$ total & $71.5 \%$ & $8.3 \%$ & $15.1 \%$ & $5.1 \%$ & $100.0 \%$ \\
\hline
\end{tabular}

Table 5.6 Cross tabulation of mode used on the toll road and income level

\begin{tabular}{|c|c|c|c|c|c|c|}
\hline \multirow[b]{3}{*}{$\begin{array}{l}\text { Mode used on the toll } \\
\text { road }\end{array}$} & \multicolumn{5}{|c|}{ Income level } & \multirow[b]{3}{*}{ Total } \\
\hline & $\begin{array}{l}\text { Low - } \\
\text { income }\end{array}$ & \multicolumn{2}{|c|}{ Medium-income } & \multicolumn{2}{|c|}{ High-income } & \\
\hline & $\begin{array}{c}<\text { IDR } 2.5 \\
\text { mil }\end{array}$ & $\begin{array}{c}\text { IDR } 2.5- \\
5 \mathrm{mil}\end{array}$ & $\begin{array}{c}\text { IDR 5-7.5 } \\
\text { mil }\end{array}$ & $\begin{array}{l}\text { IDR } 7.5- \\
10 \mathrm{mil}\end{array}$ & $\begin{array}{c}>\text { IDR } 10 \\
\text { mil }\end{array}$ & \\
\hline Private car & 198 & 140 & 272 & 122 & 74 & 806 \\
\hline $\begin{array}{r}\% \text { in mode used on the } \\
\text { toll road }\end{array}$ & $24.6 \%$ & $17.4 \%$ & $33.7 \%$ & $15.1 \%$ & $9.2 \%$ & $100.0 \%$ \\
\hline$\%$ in income level & $39.3 \%$ & $35.6 \%$ & $57.0 \%$ & $71.3 \%$ & $96.1 \%$ & $49.7 \%$ \\
\hline Taxi & 15 & 8 & 10 & 3 & 0 & 36 \\
\hline $\begin{array}{r}\% \text { in mode used on the } \\
\text { toll road }\end{array}$ & $41.7 \%$ & $22.2 \%$ & $27.8 \%$ & $8.3 \%$ & $0.0 \%$ & $100.0 \%$ \\
\hline$\%$ in income level & $3.0 \%$ & $2.0 \%$ & $2.1 \%$ & $1.8 \%$ & $0.0 \%$ & $2.2 \%$ \\
\hline Shuttle service & 46 & 43 & 32 & 16 & 0 & 137 \\
\hline $\begin{array}{r}\% \text { in mode used on the } \\
\text { toll road }\end{array}$ & $33.6 \%$ & $31.4 \%$ & $23.4 \%$ & $11.7 \%$ & $0.0 \%$ & $100.0 \%$ \\
\hline$\%$ in income level & $9.1 \%$ & $10.9 \%$ & $6.7 \%$ & $9.4 \%$ & $0.0 \%$ & $8.4 \%$ \\
\hline Bus & 245 & 202 & 163 & 30 & 3 & 643 \\
\hline
\end{tabular}




\begin{tabular}{|c|c|c|c|c|c|c|}
\hline \multirow[b]{3}{*}{$\begin{array}{l}\text { Mode used on the toll } \\
\text { road }\end{array}$} & \multicolumn{5}{|c|}{ Income level } & \multirow[b]{3}{*}{ Total } \\
\hline & $\begin{array}{l}\text { Low - } \\
\text { income }\end{array}$ & \multicolumn{2}{|c|}{ Medium-income } & \multicolumn{2}{|c|}{ High-income } & \\
\hline & $\begin{array}{c}<\text { IDR } 2.5 \\
\text { mil }\end{array}$ & $\begin{array}{c}\text { IDR } 2.5- \\
5 \text { mil } \\
\end{array}$ & $\begin{array}{c}\text { IDR 5-7.5 } \\
\text { mil }\end{array}$ & $\begin{array}{l}\text { IDR } 7.5- \\
10 \text { mil } \\
\end{array}$ & $\begin{array}{c}>\text { IDR } 10 \\
\text { mil }\end{array}$ & \\
\hline $\begin{array}{r}\% \text { in mode used on the } \\
\text { toll road }\end{array}$ & $38.1 \%$ & $31.4 \%$ & $25.3 \%$ & $4.7 \%$ & $.5 \%$ & $100.0 \%$ \\
\hline$\%$ in income level & $48.6 \%$ & $51.4 \%$ & $34.2 \%$ & $17.5 \%$ & $3.9 \%$ & $39.6 \%$ \\
\hline Total & 504 & 393 & 477 & 171 & 77 & 1622 \\
\hline$\%$ total & $31.1 \%$ & $24.2 \%$ & $29.4 \%$ & $10.5 \%$ & $4.7 \%$ & $100.0 \%$ \\
\hline
\end{tabular}

\subsection{Modelling approach}

The modelling framework applied in this study is discrete choice model. The assumption of this model is each individual in the survey will choose an alternative that has the highest utility. To examine how variations in Level of Service $(\mathrm{LoS})$ of a toll road, socio-economic attributes and latent factors simultaneously affect residential location, route and mode, three logit models are developed in this study: (1) a mixed logit with panel data to deal with the sequences of choices and with the intrinsic correlation among the choices (MLM); (2) a hybrid choice model, in which attitudes towards toll road and the travel mode are incorporated (HCM); and (3) a joint model (JM), to estimate simultaneously residential location choice and travel behaviour.

\subsubsection{Hybrid choice model (HCM)}

Figure 5.3 shows the framework of HCM used in this chapter. We adopted the methodology proposed in Walker (2001) and Ben-Akiva et al. (2002). They developed an integrated model, known as hybrid choice model, consisting of structural equations of a discrete choice model and a latent variable model and measurement equations for the psychometric indicators.

In Figure 5.3, the ellipses represent unobserved (latent) variables, while the rectangles represent observable variables. The latent variables are denoted by $L V_{n}$ for individual n. $L V_{n}$ is not an observable variable and should be identified through a set of attitudinal indicators. The latent variable models identify latent constructs as a function of the indicators and capture the causal relationships between explanatory variables and the latent variables. The dashed arrows from the latent variable to the indicators are the measurement models. The indicators are only used to estimate the latent variables and will not be used in the choice model. On the other hand, the estimated latent variables will be treated as explanatory variables in the utility function of choice alternatives, showed by solid arrows from $L V_{n}$ to the utility.

Furthermore, to construct the latent models, an exploratory factor analysis was performed of the psychometric indicators for each SC experiment. Table 5.7 lists the factor loadings and the indicators of each factor. Factors were extracted based on eigenvalues greater than 1 and selected indicators with communalities greater than 0.50 . The extraction method was principal component analysis and we used Varimax with Kaiser normalization for the rotation method. Additionally, scree plots, with factors plotted in decreasing order of eigenvalue, were used to identify which components to retain here; the addition of one more component does not necessarily add a substantial increase to the explanation of variance. Eventually, we obtained two factors that were able to explain $60 \%$ of the variance, namely 'attitude towards the travel mode used on a trip via the toll road' and 'attitude towards the toll road itself'. 


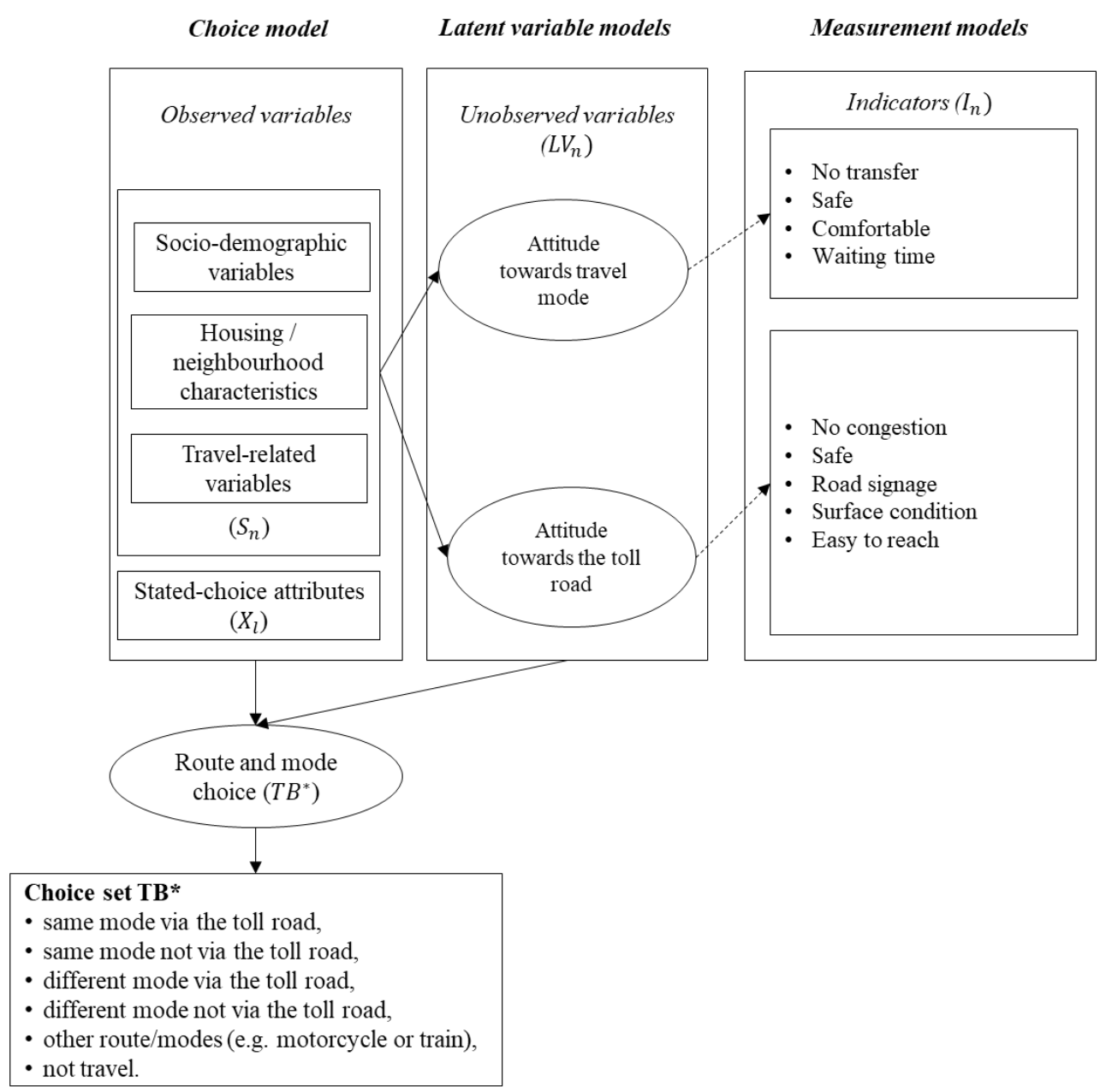

Figure 5.3. Analytical framework for HCM

Table 5.7. Factor loadings, with significant variables in bold

\begin{tabular}{|l|r|r|}
\hline \multirow{2}{*}{ Statements } & \multicolumn{2}{|c|}{ Component } \\
\cline { 2 - 4 } & $\begin{array}{l}\text { Factor 1 : attitude } \\
\text { towards travel mode }\end{array}$ & $\begin{array}{l}\text { Factor 2: attitude } \\
\text { towards the toll } \\
\text { road }\end{array}$ \\
\hline I do not have to make several transfers & $\mathbf{0 . 8 2}$ & 0.09 \\
\hline My mode is safer than the alternative mode & $\mathbf{0 . 8 5}$ & 0.15 \\
\hline $\begin{array}{l}\text { My mode is more comfortable than the alternative } \\
\text { mode }\end{array}$ & $\mathbf{0 . 8 6}$ & 0.18 \\
\hline I do not have to wait long & $\mathbf{0 . 8 5}$ & 0.10 \\
\hline There is no/low congestion on the toll road & 0.07 & $\mathbf{0 . 6 9}$ \\
\hline Driving on toll roads is safer than on non-toll roads & 0.09 & $\mathbf{0 . 7 2}$ \\
\hline $\begin{array}{l}\text { Traffic signs on toll roads are complete and very } \\
\text { clear }\end{array}$ & 0.14 & $\mathbf{0 . 7 3}$ \\
\hline Toll road has better road surface condition & 0.15 & $\mathbf{0 . 7 1}$ \\
\hline Easy to reach toll road gates from my location & 0.09 & $\mathbf{0 . 6 3}$ \\
\hline
\end{tabular}




\subsubsection{Model specifications}

For the latent variable model, the distribution of the indicators is conditional on the values of the latent variables $f_{I}\left(I_{n} \mid L V_{n} ; \alpha, \sigma_{v}\right)$. The indicator of the latent model is specified as:

$$
I_{n}=\alpha L V_{n}+v_{n}
$$

The indicator $I_{n}$ of the latent variable $L V_{n}$ is estimated through parameter $\alpha$, that needs to be estimated, and $\mathrm{v}_{n}$ is the error term, normally distributed with zero mean and standard deviation $\sigma_{v}$. Given the ranges ( 5 points-scale) and low variability of the indicators, a continuous structure provided the best model fit and was therefore used in this study. Bahamonde-Birke and Ortúzar (2017) discussed this extensively and found that in the case of low variability of the latent indicators, there was no significant difference in terms of predictability between treating the indicators as continuous or ordinal structures.

For the latent variable model, the distribution of the latent variables is given the observed variables $X_{n}, f_{L V}\left(L V_{n} \mid S_{n} ; \lambda, \sigma_{\omega}\right)$. The structural equation for the latent variable is specified as follows:

$$
L V_{n}=\sum_{q} \lambda_{q} S_{q n}+\omega_{n}
$$

Where $L V_{n}$ represents the latent variables for individual $n . \lambda$ is a vector of the explanatory parameters with $q$ elements, while $\omega_{n}$ is the error term, which is normally distributed with zero mean and standard deviation $\sigma_{\omega}$.For the choice model, the distribution of utilities is needed, $f_{c}\left(U_{n} \mid X_{l}, S_{n}, L V_{n} ; \gamma, \sigma_{\xi}\right)$. The explanatory variables in the choice model consists of alternatives' attributes, travel-related variables, neighbourhood characteristics, housing characteristics, socio-demographic variables, as well as the latent variables. In general, the choice model is expressed as the following structural equation:

$$
U_{\text {in }}=V\left(X_{l}, S_{n}, L V_{n} ; \gamma\right)+\xi_{\text {in }}
$$

$U_{\text {in }}$ is the utility for individual $n$ for alternative $i$. The random utility here is decomposed into systematic utility and a random disturbance. The systematic utility is a function of both observable and latent variables. $\gamma$ is a set of parameters to be estimated and $\xi$ is the random disturbance term with variance $\sigma_{\xi}$.

\subsubsection{Model estimation for the HCM model}

The probability of individual $n$ choosing alternative $i$ in travel behaviour choice experiment is formulated as:

$$
P\left(i, I_{n} \mid X_{l}, S_{n}, L V_{n} ; \gamma, \lambda, \alpha, \sigma_{\xi}, \sigma_{\omega}, \sigma_{\mathrm{v}}\right)=\operatorname{prob}\left\{U_{i n} \geq U_{j n}, \forall \in c_{n}\right\}
$$

Where $c_{n}$ is the choice set of the individual $n$. All alternatives are available in our case.

Utilities of alternatives are measured as binary variables $y_{i n}$, as given in equation below.

$$
y_{\text {in }}=\left\{\begin{array}{l}
1, \text { if } U_{\text {in }} \geq U_{j n}, \forall \in c_{n}, \\
0, \text { otherwise. }
\end{array}\right.
$$

The hybrid choice model is composed of choice $i$ and the latent variable. So we have to estimate the joint probability of observing choice $i$ and latent variable, $L V_{n}$. The latent variable model is 
first estimated using standard latent variable estimators (Equations 5.1 and 5.2). Next, the fitted latent variables and their distributions are used to estimate the choice model, in which the choice probability is integrated over the distribution of the latent variables.

The indicators are introduced in the model as the demonstration of the latent constructs. The addition of indicators improves the accuracy of structural parameters estimation and enables their identification. Assuming that the error components $\left(\mathrm{v}_{n}, \omega_{n}, \xi_{n}\right)$ are independent, the joint probability of observing choice $l$ and observable variables $I_{n}$, conditional on explanatory variables $S_{n}$ is:

$$
\begin{aligned}
& P\left(i, I_{n} \mid S_{n}, X_{l} ; \gamma, \alpha, \lambda, \sigma_{\xi}, \sigma_{v}, \sigma_{\omega}\right) \\
& =\int_{X^{*}} P\left(i, I_{n} \mid S_{n}, X_{l}, L V_{n} ; \gamma, \sigma_{\xi}\right) f_{I}\left(I_{n} \mid L V_{n} ; \alpha, \sigma_{v}\right) f_{L V}\left(L V_{n} \mid S_{n} ; \lambda, \sigma_{\omega}\right) d L V
\end{aligned}
$$

The maximum likelihood can be obtained by maximising the logarithm of the likelihood function over the unknown parameters:

$$
L=\sum_{n} \sum_{i \in C_{n}} y_{i n} \log P\left(i, I_{n} \mid X_{n}, S_{i}, L V_{n} ; \gamma, \lambda, \alpha, \sigma_{\xi}, \sigma_{\omega}, \sigma_{\mathrm{v}}\right)
$$

\subsubsection{Joint model (JM)}

Figure 5.4 shows the framework of the joint estimation that accommodates the toll road impacts and other influencing factors on route, mode, and location choices. As presented in the figure, two decision processes are integrated simultaneously: the residential location choice $\left(R C^{*}\right)$ and route and mode choices $\left(T B^{*}\right)$. The effect of self-selection is represented by dashed lines, because is unobserved. Both $R C^{*}$ and $T B^{*}$ are affected by the same explanatory variables, indicated by solid lines since they are considered as observable. Error components $\varepsilon$ and $\xi$ also affect $R C^{*}$ and $T B^{*}$, respectively, which are indicated by dashed lines.

In the joint-model, several variables are common to both travel behaviour and residential location choice models. Their parameters also randomly distributed to account for unobserved attributes (e.g. lifestyle or travel preferences). For instance, people who live close to the toll gate would tend to choose route via the toll road as well. Similarly, low-income individuals can only afford low housing price that tends to locate far from the toll gates, and thus are unlikely to travel using the toll road. Such unobserved preferences will be captured in the common random parameters in both models.

The equation of each model can then be written as:

$$
\begin{gathered}
R C_{i n}^{*}=A S C_{i}+\sum_{m} \beta_{m} X_{m n}+\sum_{h} \beta_{h} S_{h n}+\sum_{t} \theta_{t} Z_{t n}+\varepsilon_{n} \\
T B_{i n}^{*}=A S C_{i}+\sum_{l} \gamma_{l} X_{l n}+\sum_{p} \gamma_{p} S_{p n}+\sum_{t} \theta_{t} Z_{t n}+\xi_{n}
\end{gathered}
$$

Where the utility function of each individual $n$ is expressed a function of the stated choice attributes $\left(X_{i n}\right)$ with $m$ and $l$ elements for residential location and route-mode choices, respectively; a vector of socio-economic, housing, travel and neighbourhood characteristics $\left(S_{n}\right)$ with $h$ and $p$ elements for residential location and route-mode choices, respectively; a common vector on residential location choice and travel behaviour $\left(Z_{n}\right)$ with $t$ elements; as 
well as the error term $\varepsilon_{n}$ and $\xi_{n}$ for residential location choice and travel behaviour model, respectively. As described by Bhat and Guo (2007), self-selection can be accounted through the effect of unobserved heterogeneity to both $R C_{i n}^{*}$ and $T B_{i n}^{*}$, that is if common parameter $\theta$ is found significant in the joint model.

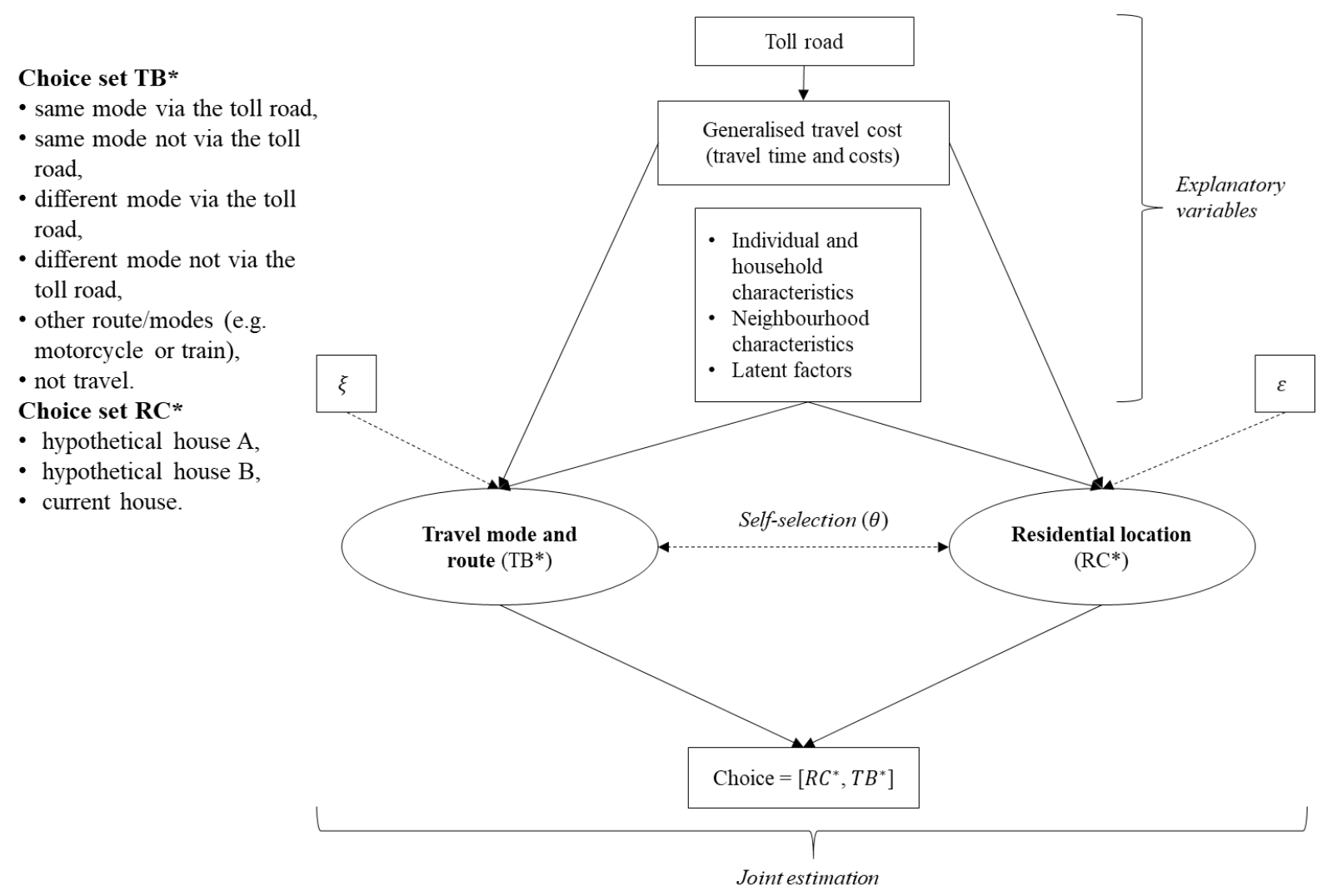

Figure 5.4. Analytical framework for residential location, route and mode choices (joint estimation)

We can then estimate the probability to choose specific residential location choice and the probability to choose one option of route and mode alternative set, as the product of probability of the residential location choice $\left(P_{i n}^{R C}\right)$ and the probability of the route and mode choices $\left(P_{i n}^{T B}\right)$. The models were estimated using the software package PythonBiogeme (Bierlaire, 2016).

$$
P_{\text {in }}=P_{\text {in }}^{R C} * P_{\text {in }}^{T B}
$$

\subsubsection{Elasticity: model application}

The estimation of direct elasticities with respect to travel cost are also of interest in this study, to show responsiveness of the population to the changes travel cost with regards to the alternatives. Travel cost on the trip via the toll road are modified by $10 \%$, keeping other variables constant and calculated the average elasticity with the following formula (Bierlaire, 2017), 


$$
\bar{E}_{X_{i n}}^{P_{i n}}=\frac{1}{N} \sum_{n=1}^{N} \frac{\Delta P_{i n}}{\Delta X_{i n}} \frac{X_{i n}}{P_{i n}}
$$

Here, $X_{i n}$ is the value of the $\operatorname{LoS}^{8}$ variable of alternative $i$ faced by individual $n ; \Delta X_{\text {in }}$ is the value of the change in variable travel cost via the toll road after the modification. $P_{i n}$ is the probability to choose alternative $i$ and $\Delta P_{i n}$ is the change in the probability after the increment of $x$.

\subsection{Model estimations}

For MLM, we tested several model specifications to arrive at the final mixed logit model that we used to estimate the joint model. This model uses error components to capture panel effects. HCM contains latent variables of attitudes toward current mode and the toll road. Furthermore, mixed logit model of residential location choice is incorporated in the joint model. We estimated common parameters of both models with the standard deviations to investigate the association between residential location, route and mode choices.

Table 5.8 presents the estimation results of each model. Estimated alternative specific constants (ASCs) and t-test shows that unobserved factors or unexplained noise is smaller in HCM than in other models, with the inclusion of the latent variables.

Furthermore, from the results of the alternative specific constants (ASCs), it can be seen that the respondents preferred travel options that made use of the toll road (Alternatives 1 and 3). The results across the three models also show that both observed and unobserved variables are essential to explain travel behaviour. We discuss more details on the results of the travel behaviour model and the joint model of residential location choice and travel behaviour in following sections.

Table 5.8. Estimation results

\begin{tabular}{|c|c|c|c|c|c|c|c|c|c|}
\hline \multirow[b]{2}{*}{ Variables } & \multirow{2}{*}{$\begin{array}{l}\text { Notation } \\
\text { parameters }\end{array}$} & \multirow{2}{*}{$\begin{array}{l}\text { Affected } \\
\text { alternati- } \\
\text { ve in } \mathrm{TB}^{9}\end{array}$} & \multicolumn{2}{|c|}{ MLM } & \multicolumn{2}{|c|}{$\mathrm{HCM}$} & \multirow{2}{*}{$\begin{array}{l}\text { Affected } \\
\text { alternati- } \\
\text { ve in } \\
\mathrm{RC}^{10}\end{array}$} & \multicolumn{2}{|c|}{$\mathrm{JM}$} \\
\hline & & & Est. & $t$ & Est. & $t$ & & Est. & $t$ \\
\hline \multirow{7}{*}{$\begin{array}{l}\text { Alternati- } \\
\text { ve specific } \\
\text { constants }\end{array}$} & $\mathrm{ASC}_{\mathrm{A}}$ & - & - & - & - & - & 1 & -16.37 & -9.25 \\
\hline & $\mathrm{ASC}_{\mathrm{B}}$ & - & - & - & - & - & 2 & -15.52 & -8.25 \\
\hline & $\mathrm{ASC}_{1}$ & 1 & 7.63 & 11.80 & - & - & - & 6.80 & 11.09 \\
\hline & $\mathrm{ASC}_{2}$ & 2 & 5.46 & 8.42 & 4.99 & 11.95 & - & 4.71 & 7.76 \\
\hline & $\mathrm{ASC}_{3}$ & 3 & 6.97 & 10.72 & -0.62 & -9.91 & - & 6.19 & 10.14 \\
\hline & $\mathrm{ASC}_{4}$ & 4 & 5.97 & 10.13 & 5.17 & 12.95 & - & 4.59 & 7.39 \\
\hline & $\mathrm{ASC}_{5}$ & 5 & 2.76 & 5.72 & 1.91 & 4.99 & - & 2.24 & 5.43 \\
\hline \multirow{2}{*}{$\begin{array}{l}\text { Trip } \\
\text { characte- }\end{array}$} & $\gamma_{\text {cost_toll_travel }}$ & $1,2,3,4$ & -0.01 & -14.55 & -0.01 & -11.01 & - & 0.00 & $\begin{array}{c}- \\
11.40\end{array}$ \\
\hline & $\gamma_{\text {time_toll_travel }}$ & $1,2,3,4$ & -0.01 & -8.17 & -0.01 & -22.04 & - & -0.01 & -6.77 \\
\hline
\end{tabular}

\footnotetext{
${ }^{8}$ Level of Service

${ }^{9}$ Alternatives of TB: $1=$ Same mode, via toll road; $2=$ Same mode, no toll road; $3=$ Different mode, via toll road; $4=$ Different mode, no toll road; $5=$ Other mode; $6=$ Will not travel

${ }^{10}$ Alternatives of RC: $1=$ Hypothetical house A; $2=$ Hypothetical house B; $3=$ Current house
} 


\begin{tabular}{|c|c|c|c|c|c|c|c|c|c|}
\hline \multirow{7}{*}{$\begin{array}{l}\text { Variables } \\
\text { ristic via } \\
\text { the toll } \\
\text { road (in } \\
\text { TB) }\end{array}$} & \multirow{2}{*}{$\begin{array}{l}\text { Notation } \\
\text { parameters }\end{array}$} & \multirow{2}{*}{$\begin{array}{l}\text { Affected } \\
\text { alternati- } \\
\text { ve in } \mathrm{TB}^{9}\end{array}$} & \multicolumn{2}{|c|}{ MLM } & \multicolumn{2}{|c|}{$\mathrm{HCM}$} & \multirow{2}{*}{$\begin{array}{c}\text { Affected } \\
\text { alternati- } \\
\text { ve in } \\
\mathrm{RC}^{10}\end{array}$} & \multicolumn{2}{|c|}{ JM } \\
\hline & & & Est. & $t$ & Est. & $t$ & & Est. & $t$ \\
\hline & \multirow{4}{*}{$\gamma_{\text {worktripselfpaid }}$} & 1 & 1.33 & 1.78 & 2.05 & 3.08 & - & 2.30 & 3.69 \\
\hline & & 2 & 2.06 & 2.78 & 2.92 & 4.04 & - & 2.87 & 4.25 \\
\hline & & 3 & 1.00 & 1.93 & 1.90 & 2.80 & - & 1.87 & 2.98 \\
\hline & & 4 & 2.09 & 3.01 & 2.88 & 4.06 & - & 3.17 & 4.19 \\
\hline & $\begin{array}{l}\gamma_{\text {bus_users_viatoll }} \\
\text { road }\end{array}$ & 2,4 & 0.17 & 5.13 & 0.25 & 7.72 & - & 0.64 & 4.39 \\
\hline \multirow{3}{*}{$\begin{array}{l}\text { Daily } \\
\text { travel } \\
\text { characte- } \\
\text { ristics (in } \\
\text { RC) }\end{array}$} & $\beta_{\text {cost_daily_travel }}$ & - & - & - & - & - & $1,2,3$ & -0.30 & -5.25 \\
\hline & $\beta_{\text {time_daily_travel }}$ & - & - & - & - & - & $1,2,3$ & -1.17 & 11.96 \\
\hline & $\beta_{\text {daily_car_user }}$ & - & - & - & - & - & 3 & & \\
\hline \multirow{2}{*}{$\begin{array}{l}\text { Neighbour } \\
\text { hood / } \\
\text { housing } \\
\text { characte- } \\
\text { ristics }\end{array}$} & $\beta_{\text {rent*high-income }}$ & - & - & - & - & - & $1,2,3$ & 0.50 & 5.64 \\
\hline & $\gamma_{\text {urban }}$ & 2 & 0.95 & 4.98 & 0.82 & 5.56 & - & 0.66 & 3.91 \\
\hline \multirow{7}{*}{$\begin{array}{l}\text { Individual } \\
\text { and } \\
\text { household } \\
\text { characte- } \\
\text { ristics }\end{array}$} & $\gamma_{\text {age }}$ & 1,3 & 0.01 & 2.23 & 0.01 & 2.87 & - & - & - \\
\hline & $\gamma_{\text {gender }}$ & $1,3,4$ & 0.27 & 1.92 & - & - & - & 0.26 & 1.76 \\
\hline & $\beta_{\text {gender }}$ & - & - & - & - & - & 3 & - & - \\
\hline & $\beta_{\text {housemember }}$ & - & - & - & - & - & 3 & - & - \\
\hline & $\gamma_{\text {high-income }}$ & 1 & 0.13 & 2.49 & 0.39 & 1.93 & - & - & - \\
\hline & $\beta_{\text {mid-income }}$ & - & - & - & 0.80 & 7.28 & 1,3 & -6.86 & -6.52 \\
\hline & $\gamma_{\text {mid-income }}$ & 1,3 & 0.27 & 5.43 & - & - & - & 0.45 & 3.08 \\
\hline \multirow{6}{*}{$\begin{array}{l}\text { Common } \\
\text { random }\end{array}$} & $\theta_{\text {low-income }}$ & $1,2,3,4$ & -1.62 & -6.22 & -0.96 & -4.11 & 1,3 & -1.31 & -4.53 \\
\hline & $\theta_{\text {low-income-std }}$ & $1,2,3,4$ & - & - & - & - & 1,3 & 0.38 & 1.79 \\
\hline & $\theta_{\text {proxy }}$ & 1,3 & -0.09 & -1.71 & 0.00 & -0.02 & 3 & -0.23 & -2.88 \\
\hline & $\theta_{\text {proxy_std }}$ & 1,3 & - & - & - & - & 3 & -0.06 & -2.85 \\
\hline & $\begin{array}{l}\theta_{\text {freq_user_toll- }} \\
\text { road }\end{array}$ & 2,4 & -0.55 & -4.36 & -0.70 & -6.38 & 3 & -0.56 & -3.80 \\
\hline & $\begin{array}{l}\theta_{\text {freq_user_toll- }} \\
\text { road_std }\end{array}$ & 2,4 & - & - & - & - & 3 & -1.42 & -5.16 \\
\hline \multirow{2}{*}{$\begin{array}{l}\text { Latent } \\
\text { variables } \\
\text { (in TB) }\end{array}$} & $\gamma_{\mathrm{LV} \_ \text {currentmode }}$ & 1,3 & - & - & 0.77 & 6.09 & - & - & - \\
\hline & $\gamma_{\mathrm{LV} \_ \text {tollroad }}$ & 1,3 & - & - & 1.33 & 11.51 & - & - & - \\
\hline \multirow{2}{*}{$\begin{array}{l}\text { Non- } \\
\text { choosing } \\
\text { behaviour }\end{array}$} & $\beta_{\text {non-choosing }}$ & - & - & - & - & - & 3 & - & - \\
\hline & $\gamma_{\text {non-choosing }}$ & 1 & 3.24 & 3.70 & 2.91 & 12.35 & - & 2.55 & 5.92 \\
\hline \multirow{9}{*}{$\begin{array}{l}\text { Error } \\
\text { compo- } \\
\text { nents }\end{array}$} & $\sigma_{\text {sigma_houseA }}$ & - & - & - & - & - & 1 & 4.42 & 13.32 \\
\hline & $\sigma_{\text {sigma_houseB }}$ & - & - & - & - & - & 2 & 4.34 & 12.33 \\
\hline & $\sigma_{\text {sigma_houseC }}$ & - & - & - & - & - & 3 & 6.52 & 8.72 \\
\hline & $\sigma_{\text {sigma_ST }}$ & 1 & 1.29 & 14.10 & -1.13 & -15.20 & - & -1.05 & -9.99 \\
\hline & $\sigma_{\text {sigma_SNoT }}$ & 2 & -1.35 & -14.29 & -1.39 & -16.20 & - & 1.11 & 7.66 \\
\hline & $\sigma_{\text {sigma_DT }}$ & 3 & 1.10 & 12.52 & 0.98 & 12.81 & - & 0.72 & 5.08 \\
\hline & $\sigma_{\text {sigma_DNoT }}$ & 4 & 1.29 & 10.21 & 1.33 & 11.51 & - & 0.66 & 1.90 \\
\hline & $\sigma_{\text {sigma_OM }}$ & 5 & 3.25 & 15.60 & 3.34 & 20.53 & - & -2.97 & $\begin{array}{c}- \\
10.21\end{array}$ \\
\hline & $\sigma_{\text {sigma_WNT }}$ & 6 & -3.36 & -10.34 & 3.03 & 11.70 & - & -2.58 & -7.42 \\
\hline \multirow{2}{*}{ Intercept } & $\lambda_{\text {intercept1 }}$ & LV1 & - & - & 3.84 & 78.25 & - & - & - \\
\hline & $\lambda_{\text {intercept2 }}$ & LV2 & - & - & 1.17 & 1.65 & - & - & - \\
\hline \multirow{2}{*}{ Location } & $\lambda_{\text {bandung }}$ & LV2 & - & - & 0.07 & 1.63 & - & - & - \\
\hline & $\lambda_{\text {cimahi }}$ & LV2 & - & - & 0.07 & 1.62 & - & - & - \\
\hline
\end{tabular}




\begin{tabular}{|c|c|c|c|c|c|c|c|c|c|}
\hline \multirow{5}{*}{ Variables } & \multirow{2}{*}{$\begin{array}{l}\text { Notation } \\
\text { parameters }\end{array}$} & \multirow{2}{*}{$\begin{array}{l}\text { Affected } \\
\text { alternati- } \\
\text { ve in } \mathrm{TB}^{9}\end{array}$} & \multicolumn{2}{|c|}{ MLM } & \multicolumn{2}{|c|}{$\mathrm{HCM}$} & \multirow{2}{*}{$\begin{array}{c}\text { Affected } \\
\text { alternati- } \\
\text { ve in } \\
\mathrm{RC}^{10}\end{array}$} & \multicolumn{2}{|c|}{$\mathrm{JM}$} \\
\hline & & & Est. & $t$ & Est. & $t$ & & Est. & $t$ \\
\hline & $\lambda_{\text {purwakarta }}$ & LV2 & - & - & 0.08 & 2.19 & - & - & - \\
\hline & $\lambda_{\text {proxy }}$ & LV1 & - & - & -0.03 & -4.30 & - & - & - \\
\hline & $\lambda_{\text {control }}$ & LV2 & - & - & 0.12 & 3.28 & - & - & - \\
\hline \multirow{3}{*}{$\begin{array}{l}\text { Travel } \\
\text { characte- } \\
\text { ristics }\end{array}$} & $\lambda_{\text {daily_PT_user }}$ & LV1 & - & - & 0.16 & 2.68 & - & - & - \\
\hline & $\begin{array}{l}\lambda_{\text {bus_user_viatoll- }} \\
\text { road }\end{array}$ & LV1 & - & - & 0.03 & 4.00 & - & - & - \\
\hline & $\begin{array}{l}\lambda_{\text {freq_user_toll- }} \\
\text { road }\end{array}$ & LV1 & - & - & -0.06 & -1.55 & - & - & - \\
\hline \multirow{3}{*}{$\begin{array}{l}\text { Individual } \\
\text { characte- } \\
\text { ristics }\end{array}$} & $\lambda_{\text {high_income }}$ & LV1 & - & - & 0.20 & 3.15 & - & - & - \\
\hline & $\lambda_{\text {low_income }}$ & LV1 & - & - & -0.17 & -3.50 & - & - & - \\
\hline & $\lambda_{\text {low_income }}$ & LV2 & - & - & 0.18 & 3.37 & - & - & - \\
\hline \multirow{7}{*}{$\begin{array}{l}\text { Indicators } \\
\text { on latent } \\
\text { variable of } \\
\text { attitudes } \\
\text { towards } \\
\text { the travel } \\
\text { mode }\end{array}$} & $\sigma_{\text {notransfer }}$ & LV1 & - & - & -0.11 & -4.89 & - & - & - \\
\hline & $\alpha_{\text {mode_safe }}$ & LV1 & - & - & -0.27 & -10.08 & - & - & - \\
\hline & $\sigma_{\text {mode_safe }}$ & LV1 & - & - & -0.02 & -1.13 & - & - & - \\
\hline & $\alpha_{\text {mode_comfortable }}$ & LV1 & - & - & -0.26 & -10.69 & - & - & - \\
\hline & $\sigma_{\text {mode_comfortable }}$ & LV1 & - & - & -0.04 & -2.18 & - & - & - \\
\hline & $\begin{array}{l}\alpha_{\text {mode_waiting- }} \\
\text { time }\end{array}$ & LV1 & - & - & 0.04 & 1.70 & - & - & - \\
\hline & $\begin{array}{l}\sigma_{\text {mode_waiting- }} \\
\text { time }\end{array}$ & LV1 & - & - & -0.14 & -6.25 & - & - & - \\
\hline \multirow{5}{*}{$\begin{array}{l}\text { Indicators } \\
\text { on latent } \\
\text { variable of } \\
\text { attitudes } \\
\text { towards } \\
\text { the toll } \\
\text { road }\end{array}$} & $\sigma_{\text {toll_safe }}$ & LV2 & - & - & -0.61 & -17.09 & - & - & - \\
\hline & $\alpha_{\text {toll_signage }}$ & LV2 & - & - & 0.04 & 2.21 & - & - & - \\
\hline & $\sigma_{\text {toll_signage }}$ & LV2 & - & - & -0.70 & -17.91 & - & - & - \\
\hline & $\alpha_{\text {toll_nocongestion }}$ & LV2 & - & - & -0.33 & -12.77 & - & - & - \\
\hline & $\sigma_{\text {toll_nocongestion }}$ & LV2 & - & - & -0.17 & -7.01 & - & - & - \\
\hline \multicolumn{10}{|c|}{ Goodness of fit: } \\
\hline \multicolumn{3}{|c|}{ Number of estimated parameters: } & \multicolumn{2}{|c|}{27} & \multicolumn{2}{|c|}{52} & \multicolumn{3}{|c|}{37} \\
\hline \multicolumn{3}{|c|}{ Final log likelihood: } & \multicolumn{2}{|c|}{-10614.48} & \multicolumn{2}{|c|}{-93389.78} & \multicolumn{3}{|c|}{-14366.28} \\
\hline \multicolumn{3}{|c|}{ Rho-square-bar : } & \multicolumn{2}{|c|}{0.34} & \multicolumn{2}{|c|}{0.52} & \multicolumn{3}{|c|}{0.48} \\
\hline \multicolumn{3}{|c|}{ Akaike Information Criterion (AIC): } & \multicolumn{2}{|c|}{21330.88} & \multicolumn{2}{|c|}{186793.81} & \multicolumn{3}{|c|}{28806.56} \\
\hline \multicolumn{3}{|c|}{ Bayesian Information Criterion (BIC): } & 215 & & 187 & 63.18 & & 068.07 & \\
\hline & & ample size: & & & & 84 & & 8672 & \\
\hline
\end{tabular}

Table 5.8 shows the goodness of fit. Analysing the values of rho-squared, we can observe that the HCM has the best fit. Since these models have different parameters sets and structures, the AIC and BIC were calculated; they indicate that the HCM yields the most robust results. It means that latent variables represent the behaviour better than the simultaneous estimation of the unobserved effects. However, it is important to highlight that the joint model incorporates both phenomena of residential location choice and travel behaviour, whereas the HCM only represents travel behaviour. When comparing the HCM and JM models with the standard mixed logit model (MLM), we can observe that both models perform better than the standard MLM. It means that unobserved effects are well-represented, as latent constructs and self-selection. While this means that the statistics are informative, when interpreting the statistics, one should also look closely at the estimation results. 


\subsubsection{Results from travel behaviour models (MLM and HCM)}

The estimation results from MLM and HCM reveal that travel costs and time variations affect the model negatively and this is consistent in all models. Regarding trip characteristics via the toll road, people who travelled for work trips and needed to pay for these own trips without getting reimbursed valued options without the toll road more than other travellers. In addition, bus users preferred alternatives without the toll road. As Table 5.8 shows, bus users were dominated by low-income respondents who thus tried to avoid high travel costs. Other socioeconomic characteristics that are significant to explain route and mode choices are age and gender. We found that age and gender (male) are positively correlated with choosing toll road options.

In HCM, two latent variables were manifested by psychometric indicators, as described in Section 5.5.1: (1) attitudes towards the current mode and (2) attitudes towards the toll road. Both latent variables have a significant influence on the choice for travel route and travel mode; and are positively associated with the toll road options (alternatives 1 and 3 ). A positive attitude towards the current travel mode and towards the toll road positively affects choice options, including travelling via the toll road and still using the same mode, in line with Chen and Wen (2014).

The indicators used in the measurement model of latent variable of attitude towards the current mode were 'no transfer', 'safety', 'comfort', and 'waiting time for the mode'. Table 5.8 shows that all indicators were significant at the $95 \%$ confidence level, except for the indicator of 'waiting time', and thus adequately explained the latent variable. This result implies that the respondents preferred a travel mode that offered safety, comfort and convenience (with fast and direct service), consistent with similar studies on mode choices (e.g. Habib, Kattan, \& Islam, 2011; Johansson, Heldt, \& Johansson, 2006).

Furthermore, the indicators that represent attitude towards the toll road are 'safety', 'signage completeness' and 'no congestion'. The indicators are highly significant, indicating the representativeness of the latent variable through this measure. These results are in accordance with previous studies related to route choice. The safety of a route is obviously important from a driver's viewpoint. Wachs (1967) has shown that safety becomes more important to drivers as the trip distance increases. The Cipularang toll road is a regional toll road that connects two metropolitan areas and is, thus, dominated by long-distance trips. For this type of trip, drivers normally rely on signs along the road (Wootton, Ness, \& Burton, 1981). Moreover, as found in many behavioural studies (e.g. Papinski, Scott, \& Doherty, 2009), people prefer to avoid congestion and maximise route directness.

The respondents in our study, in general, revealed a positive attitude towards the Cipularang toll road, as shown by positive values in all location-related variables. Respondents living in more than $5 \mathrm{~km}$ from the toll gate also perceive the toll road positively. Moreover, although bus users preferred not to travel via the toll roads, as evident from Table 5.8, they still perceived the toll road positively. Low-income respondents had negative attitudes towards their travel current mode yet perceived the toll road positively. These respondents had the lowest average satisfaction with their current travel mode, in terms of safety, comfort and waiting times. 


\subsubsection{Self-selection test: joint model (JM) estimation results}

Self-selection between residential location, route and mode choices was identified through estimating JM. Table 5.8 shows that most parameters in JM remain significant with similar values resulting from both MLM and DCM after simultaneous estimation. Among those parameters, three are common parameters in both residential location and route/mode choices: distance to toll gate, frequent use of toll road and low-income. These parameters were firstly tested as specific parameters for $R C^{*}$ and $T B^{*}$, and similar parameters were then tested using a t-test if they were not significantly different. Equal values of estimated parameters indicated a share of unobserved factors. Common random parameters, with mean and standard deviation, were then further estimated. The random parameter represents the person's tastes and varies over the decision-makers rather than being fixed as in standard logit model (Train, 2009).

The three common parameters were found to be significant in the joint model at the $95 \%$ confidence level, except for standard deviation of low-income that is significant at the $90 \%$ confidence level. This indicates an association between residential location and route/mode choices, interpreted as self-selection. This association indicates the interaction between the direct impact of the toll road in terms of travel behaviour and the indirect impact of the toll road, namely stimulating people to relocate.

The results also that low-income respondents preferred opt-out choices, which were to not travel via the toll road and to choose a different mode instead (such as train or motorcycle; note that motorcycles are not allowed on most toll roads in Indonesia). This supports the findings of Herwangi et al. (2015) that lower-income individuals in Indonesia are still highly dependent on motorcycles for travel, and therefore not allowed on the toll road. In addition, this result strengthen the argument of several authors (e.g. Louviere \& Hensher, 1983) who indicate that having a 'no choice' alternative enables a more realistic experiment as well as predictions of total demand.

Additionally, there is an association between residential location choice and route and mode choice; low-income respondents who selected opt-out choices also preferred to relocate. This implies dissatisfaction with their current situation. As concluded in Chapter 4, the decision to remain or relocate from one's current residence is greatly influenced by the level of satisfaction with the current neighbourhood and housing.

Respondents who frequently travelled via the toll road would not choose options without the toll road. The negative sign on the residential location choice indicates that frequent users of the toll road also tend to relocate. Moreover, we found that respondent living close to toll gates would prefer to use the toll road, and those respondents were also likely to stay in their current residence. This is in line with the results found in Chapter 4, that satisfaction with neighbourhood is inversely proportional with proximity from toll gate, and therefore, respondents living in proximity from toll gates were likely to remain in their current residence. On the contrary, people were less satisfied with the size and affordability of their housing if they were living closer to the toll gate, probably due to higher rents or land taxes. This result indicates that the current situation of the respondents affected their choices, consistent with the work of Habib and Miller (2009) in relation to the role of the status quo in housing choices. 


\subsection{Model application}

The model output of the joint model was then used to estimate elasticities. In our study, the elasticity indicates the responsiveness in the probability of choosing an alternative if the value of travel cost is increased by $10 \%$. We estimated them for several population segments to investigate to sensitiveness of different segments towards the increment in travel cost. We based the population segments on the respondents' travel and socio-economic characteristics, as they significantly explained travel behaviour in the choice model. As we were focusing on how the toll road affects travel behaviour, we used travel cost to estimate the elasticities.

Table 5.9 shows the elasticities of the probability of choosing that alternative, for each alternative, in response to increasing the travel costs by $10 \%$. Overall, elasticity of the respondents in this sample is -0.29 , meaning that the increment of travel costs by $10 \%$ decreases the probability of choosing the same travel mode and travel via the toll road by $2.9 \%$. This result, moreover, vary across various population segments.

Car users show the highest elasticity, compared with respondents who use a bus or shuttle service. This result is in line with what was found by Belgiawan, Ilahi, and Axhausen (2018), who estimated point elasticities of travel cost with regards to road pricing implementation in Jakarta. They found that car users (with an elasticity of -0.42 , which is very similar to the result in our study) were more sensitive to increased travel cost than public transport and motorcycle users, and thus concluded that implementation of a toll could be a good policy to reduce car usage. Similarly, Li, Lau, and Seah (2011) found a higher cost elasticity for car users than for public transport users in Singapore, implying that changes in usage costs have a great impact on car users who drive to work and has no impact on public transport users. Their results are consistent with ours, where the elasticity of bus or public transport users is very small, -0.12 , the lowest among the respondents.

This result can be explained because travel cost for car is also higher than other modes in the sample. The average travel cost for car per trip is 187,140 IDR (equivalent to 11.7 EUR), meanwhile the average travel costs for bus and shuttle service per trip are 75,342 IDR (equivalent to 4.7 EUR) and 109,580 IDR (equivalent to 6.8 EUR), respectively. Thus, increased travel cost for car will have more impacts on the utility.

In contrast with other studies (e.g. Musso et al., 2013), we found high-income users to be the most sensitive relative to other income groups, which can be explained by the fact that the travel mode for trips via the toll road for high-income users was dominated by car use (96\%). Kayser (2000) found similar results in the case of increases in petrol price and argued that this was perhaps because of the greater proportion of trips taken by high-income respondents. The survey statistics also showed that high-income respondents frequently travelled via the toll road. Low-income respondents already make little use of the toll road and this leaves little room for reductions. Furthermore, we found that low-income respondent mostly travelled by bus and, thus, were less sensitive to increased travel cost (smaller elasticity value). We were able to explain these findings further by looking at income groups. Low-income car users are found to be the most sensitive to changes in travel cost compared to medium and high-income car drivers. This group would be the most affected if the toll fee would be increased.

Moreover, variation observed in these elasticities are explained by other factors, such as trip purpose, frequency trips and trip length. Long-distance trips via the toll road (more than 2 hours), frequent users and work trips were found more affected with increased travel costs than their counterparts. These results are according to expectation and consistent with previous studies (e.g. Wuestefeld \& Regan III, 1981). 
Table 5.9. Elasticities (with $10 \%$ travel cost increment)

\begin{tabular}{|c|c|c|c|c|c|c|c|c|}
\hline \multirow[b]{2}{*}{ Segment } & \multicolumn{4}{|c|}{ Same mode, via the toll road } & \multicolumn{4}{|c|}{ Different mode, via the toll road } \\
\hline & $\bar{E}$ & $\begin{array}{l}\text { Relative } \\
\text { change } \\
\text { of } \bar{P}\end{array}$ & $\begin{array}{c}\bar{P} \\
\text { baseline }\end{array}$ & $\bar{P}$ after & $\bar{E}$ & $\begin{array}{l}\text { Relative } \\
\text { change } \\
\text { of } \bar{P}\end{array}$ & $\begin{array}{l}\bar{P} \\
\text { baseline }\end{array}$ & $\bar{P}$ after \\
\hline Car & -0.43 & $-4.3 \%$ & 0.38 & 0.37 & -0.10 & $-1.0 \%$ & 0.28 & 0.28 \\
\hline Bus & -0.12 & $-1.2 \%$ & 0.42 & 0.42 & -0.34 & $-3.4 \%$ & 0.18 & 0.18 \\
\hline Shuttle & -0.23 & $-2.3 \%$ & 0.41 & 0.40 & -0.14 & $-1.4 \%$ & 0.24 & 0.23 \\
\hline $\begin{array}{l}\text { Low-income car } \\
\text { users }\end{array}$ & -0.46 & $-4.6 \%$ & 0.34 & 0.33 & -0.10 & $-1.0 \%$ & 0.24 & 0.24 \\
\hline $\begin{array}{l}\text { Medium-income } \\
\text { car users }\end{array}$ & -0.42 & $-4.2 \%$ & 0.39 & 0.38 & -0.06 & $-0.6 \%$ & 0.32 & 0.32 \\
\hline $\begin{array}{l}\text { High-income car } \\
\text { users }\end{array}$ & -0.39 & $-3.9 \%$ & 0.40 & 0.39 & -0.23 & $-2.3 \%$ & 0.24 & 0.24 \\
\hline Low-income & -0.27 & $-2.7 \%$ & 0.38 & 0.38 & -0.20 & $-2.0 \%$ & 0.22 & 0.22 \\
\hline Medium-income & -0.31 & $-3.1 \%$ & 0.42 & 0.41 & -0.18 & $-1.8 \%$ & 0.27 & 0.27 \\
\hline High-income & -0.37 & $-3.7 \%$ & 0.41 & 0.40 & -0.24 & $-2.4 \%$ & 0.24 & 0.23 \\
\hline Work trip & -0.32 & $-3.2 \%$ & 0.41 & 0.40 & -0.17 & $-1.7 \%$ & 0.23 & 0.23 \\
\hline Leisure trip & -0.29 & $-2.9 \%$ & 0.39 & 0.39 & -0.21 & $-2.1 \%$ & 0.24 & 0.24 \\
\hline $\begin{array}{l}\text { Trip more than 2- } \\
\text { hours }\end{array}$ & -0.42 & $-4.2 \%$ & 0.37 & 0.36 & -0.32 & $-3.2 \%$ & 0.23 & 0.23 \\
\hline $\begin{array}{l}\text { Trip less than 2- } \\
\text { hours }\end{array}$ & -0.19 & $-1.9 \%$ & 0.42 & 0.42 & -0.10 & $-1.0 \%$ & 0.25 & 0.25 \\
\hline Frequent user & -0.30 & $-3.0 \%$ & 0.39 & 0.38 & -0.20 & $-2.0 \%$ & 0.24 & 0.24 \\
\hline Infrequent user & -0.27 & $-2.7 \%$ & 0.41 & 0.40 & -0.19 & $-1.9 \%$ & 0.24 & 0.24 \\
\hline All & -0.29 & $-2.9 \%$ & 0.40 & 0.39 & -0.20 & $-2.0 \%$ & 0.24 & 0.24 \\
\hline
\end{tabular}

\subsection{Conclusions}

The aim of our study was to provide insight on how variations in travel time and cost of the Cipularang toll road, socio-economic attributes and latent factors simultaneously affect residential location, route and mode choices across population segments. The Cipularang toll road, in the Jakarta-Bandung region in Indonesia, was used as the case for this study. The analysis is based on a RP/SP survey with 1,600 respondents. We developed three discrete choice models to investigate route and mode choices: (1) a mixed logit model (MLM), (2) a hybrid choice model (HCM), and (3) a joint model of residential location choice and travel behaviour (JM). The main conclusions are as follows.

Firstly, our analysis shows that the toll road affects both residential location choice and travel behaviour. This influence differs between (income) groups, travel mode groups and on trip characteristics. In general, our respondents preferred using the toll road even if toll fees are increased significantly, which is also reflected in their positive attitude towards the toll road. However, bus users and low-income respondents would rather not travel via the toll road. Respondents who travelled for work and needed to pay for their travel would value options without the toll road higher than options with the toll road.

Secondly, we further found evidence of residential self-selection, in particular for low-income groups, frequent users and respondents living close to the toll road. This self-selection indicates the interaction between the direct impact of the toll road -in terms of travel behaviour- and the indirect impact of the toll road, that is, location decisions of households. Low-income 
respondents preferred opt-out options, which were to not travel via the toll road and choose a different mode instead (such as train or motorcycle), and tended to want to relocate. This implies dissatisfaction with their current situation, as also shown by their negative attitude towards their current travel mode, and they would rather choose a different situation. In addition, frequent users of the toll road would not choose options without the toll road and had the tendency to relocate. Respondent living close to toll gate would also prefer to use the toll road, and those respondents were likely to stay in their current residence. Particularly, the (HCM) modelling work shows that both route and mode choice are affected by the satisfaction of the respondents with their current residential situation.

Thirdly, we found that controlling for travel and socio-economic characteristics is important to investigate the changes in demand to travel via the toll roads. For example, car users were found to be the most sensitive toward increased travel costs. Additionally, the variation we observed in these elasticities are explained by other factors, such as trip purpose, frequency trips and trip length.

From a methodological perspective, we found that the inclusion of attitudinal effects in hybrid choice model and a self-selection test via the joint-model also improved the model's performance. We can, therefore, conclude that both observed and unobserved factors are essential to explain choice for residential location, travel mode and travel route.

This analysis contributes to a better understanding of the impact on individuals of the establishment of a toll road in the short and long term. There are several directions for future research. This study can be extended to incorporate medium-term decisions, such as vehicle ownership, in response to the toll road's existence. Future research should also focus on the behaviour of frequent users and their preference towards residential location. We were not able to do this because of sample limitations. 


\section{Conclusions and recommendations}

This final chapter consists of three sections. Firstly, it presents the conclusions of the four chapters, each of which addresses one research question. The second section describes the policy implications. Finally, the study's limitations and directions for further research are given in the last section.

\subsection{Conclusions}

The main objective of this thesis was "to provide a comprehensive understanding of the direct and indirect impacts of toll roads in the Jakarta - Bandung region in Indonesia, and how these impacts differ between geographical regions and population groups".

In order to address this research objective, four research questions were identified and discussed in the preceding four chapters. The first two of these four chapters concerned the regional impact of the toll road, while the remaining two focused at the individual level. In Chapter 2, we looked at the extent to which the construction of a major toll road in the Jakarta - Bandung region in Indonesia induces the development of local road projects in the vicinity of the toll road. In Chapter 3, we examined the impact of the Cipularang toll road on job accessibility and spatial equity by isolating the effect of the toll road. Chapter 4 addressed the influence of the Cipularang toll road, together with socio-economics, travel characteristics, housing characteristics and latent variables on residential location choice. Finally, Chapter 5 provided some insight into how changes in Level of Service (LoS) of the Cipularang toll road and socioeconomic attributes simultaneously affect residential location, route and mode choices across population segments.

This thesis provided empirical evidence that a toll road can have direct and indirect effects and that these effects can be distributed unevenly across geographic regions and individuals. This thesis also showed that the construction of a new toll road could have both positive and negative impacts, especially in a region with an imbalanced distribution of activities, an incompletely developed transport system and a high inequality of income. 
The findings of this study urge the incorporation of accessibility planning and equity concerns into the policy practice. Accessibility planning underlines the integration of land use and transport planning with the goal of enabling all individuals, regardless of their social class or ability, to participate in any activities in the area by using the current transport system. This thesis also emphasises the importance of the transport policy cycle, and that ex-post evaluations are essential to assess whether objectives are being accomplished as well as to identify indirect effects. Ex-post evaluations are necessary to either find support for the adopted rationale or the need to change transport policy.

The study addressed four research questions for which the outcomes are discussed hereafter.

\section{To what extent does the construction of national toll road projects induce local road projects in Indonesia?}

This research question is addressed in Chapter 2. The chapter investigated the relationship between national road investments and the decision-making for local road projects. It is particularly relevant in Indonesia, where the different levels of government share the responsibility for the transport networks. Indonesia's central government authorises investments in national roads, e.g. toll roads, while the lower-tier levels of government control local road projects. Local roads connect districts and communities, carry low traffic volumes and have the lowest speed limit. Coordination, however, has become a major concern to increase the benefits of transport investment across regions.

To this end, the following four models were developed to investigate induced supply of local roads: (1) a decision-making (base) model, (2) a direct effects model, (3) an indirect effects model, and (4) a composite model. The first model is related to decision-making factors, such as investment cost, the length of the road project, location, road type and government involvement. The second model is an extension of the first model, including variables of the time gap between the construction year of local roads and the opening year of the closest toll road gate, and the distance between toll gate and local road project. The third model assumes that urban development triggers local roads construction. Thus, the third model improves the base model by including variables of residential and industrial land use changes, and population changes. Finally, the fourth model is the composite model, which combines the base, direct and indirect effect models.

The outcomes of the modelling work showed that existing and planned toll roads induce the development of local road projects both directly and indirectly. Local road projects tend to be developed in anticipation of the opening of the toll road, and advocated by local governments to reduce travel time. The changes in residential area and population around the toll roads also induce local road construction. However, these variables were found to be less sensitive than other variables included in this study, such as distance to toll gate, time gap in years between toll road construction and local road project and investment cost. Further, this research found that local government tends to invest in local roads located not in urban areas since those are already densely populated and connected enough or because land acquisition would be costly in such areas.

With regard to decision-making, local governments in Indonesia were seen to prioritise the construction of longer links that are already included in regional spatial plans. It was also found that the government prefers to select expensive projects, as bigger projects are perceived to have greater accessibility benefits as well as to be of greater political interest. These findings 
strengthen the argument that it is necessary to take into account not only induced-demand effects, but also induced-supply effects in the economic appraisals of road projects.

\section{What is the impact of the Cipularang toll road on job accessibility and spatial equity in the Jakarta - Bandung region?}

This research question is answered in Chapter 3, aiming to gain a better understanding of how the benefits of a new major toll road are distributed over the adjacent areas. Few examples of toll road impacts studies in the literature are ex-ante studies, thus this chapter present an expost evaluation of the impact of a toll road on job accessibility and spatial equity in a developing country context, which to the author's knowledge has not been done before.

To address this research question, various indicators were applied to measure job accessibility and spatial equity in scenarios with and without toll road. A macroscopic traffic simulation model, using Traffic Analyst, an ArcGIS extension, was deployed to obtain valid estimates of travel time and generalised cost, taking into account congestion effects and value of time (stated-choice based).

There are many ways to measure accessibility. Here, two accessibility indicators were used. A potential accessibility measure and the Shen index to include competition effects. The Shen index (Shen, 1998) measures the proportion of the number of jobs within reach of a resident from an origin within a certain travel distance (potential supply) to the working population within reach of the same destination (potential demand). A log-logistic distance decay function produced the best fit with the travel data and was applied to estimate the potential job and working population accessibility.

Similarly as for accessibility measures, there are many ways to assess equity. In this study, equity impacts were assessed by using the Gini coefficient and Palma ratio as well as the spatial distribution of the accessibility changes, with a two-step cluster method. The Gini coefficient was estimated by using a trapezoidal Lorenz curve approximation, depicting the (ranked) cumulative share of accessibility against the cumulative share of the corresponding population by district across the Jakarta - Bandung region. The Palma ratio is rarely used in transport studies, but arguably provides a more accurate reflection of inequity as it focuses on the extremes (Banister, 2018). It is the ratio between the average accessibility of the richest $10 \%$ and the poorest $40 \%$ districts.

The results show that areas along the toll road and close to the toll gates have been most affected by the construction of the Cipularang toll road. The construction of the Cipularang toll road has reduced the average travel time in the Jakarta-Bandung area by 13\%. The most strongly impacted regions are located in the north-western area in Jakarta and the south-eastern region in Bandung. Regions in the west, such as Bogor and Cianjur, appear least affected by the development of Cipularang toll road. For specific origin-destination pairs located at the end points of the toll road, the travel time is now up to 1.5 times shorter.

The accessibility of employment and the working population each have increased by $5 \%$ as a result of the establishment of the Cipularang toll road. The new toll road is also enabling the working population in the two large cities to access new jobs emerging in the new industrial areas along the toll road, and the Shen index results confirms that the toll road is leading to increased job competition. More workers can now access jobs available in the job-poor area between Jakarta and Bandung, resulting in a (small) decrease in the amount of accessible jobs 
per worker. Most affected areas have a relatively large working population compared to number of jobs and experienced residential land use growth.

Furthermore, the construction of the toll road was found to have no impact on spatial inequity, as shown by the results of the Palma Ratio and Gini Coefficient. However, this measurement does not take mode choice into account. Low-income workers rely on motorcycles, which are not allowed on most toll roads. This does mean that higher income workers benefit stronger than lower-income workers.

These findings lead to the conclusion that a new toll road in an un-mature road network and an imbalance in the distribution of jobs and workers can result in both positive and negative equity impacts in the surrounding regions. It is worth noting that this result, however, could vary depend on the choice and operationalisation of accessibility and equity indicators (see also discussions in Pritchard et al., 2019).

\section{What is the impact of the Cipularang toll road on residential location choice?}

Chapters 2 and 3 focused on the regional impacts of the construction of the Cipularang toll road. Chapter 4 focuses on the dimension of the individual as it investigates residential location choice in response to the presence of the new toll road. This chapter presents a comprehensive ex-post evaluation of toll road construction in the context of developing countries, using a joint revealed and stated preference data.

Four choice models on residential location decision were developed, of which three included latent variables (hybrid choice models). A hybrid choice model was developed to model the effects of socio-economics, travel characteristics and housing characteristics on residential location choice simultaneously, with the latent variable model focusing on satisfaction with current neighbourhood and housing. Four models of distance to the toll gate were also estimated. The results show that the toll road affects residential location choice and that this influence varies with distance to the toll gate as well as among various income groups, municipalities and housing types. People in high-income segments are willing to pay higher land taxes to live closer than $5 \mathrm{~km}$ to the toll road to capture travel time benefits, whereas people with medium and low incomes prefer to live beyond $10 \mathrm{~km}$ from the toll gates where housing tends to be less expensive. Living farther away from the toll gate enables them to reduce their housing costs or afford a larger home at lower or similar costs. Nevertheless, this also means living farther from numerous urban facilities, such as hospitals and good schools.

The modelling results show that variation in satisfaction with the current housing and neighbourhood significantly affects housing choice. The addition of satisfaction with the current housing situation and neighbourhood to the model increased the probability that people will stay in their current residence, with the exception of low-income individuals. Respondents in the Jakarta-Bandung region tend to be more satisfied with their neighbourhood if they live close to the toll gate, but they are also less satisfied with the size and affordability of their homes if they live close to the toll gates.

Omitting satisfaction with current housing and neighbourhood tended to lead to overestimation of the probability that people will relocate. However, in particular population segments, the addition of latent factors reduced the probability that people will stay in their current residence. For instance, the average probability for the low-income segment is lower in the hybrid choice model $(46.9 \%)$ than in the mixed logit model $(48.0 \%)$. It can be interpreted as that people with 
lower incomes feel less satisfied with their current housing and neighbourhood. Indeed, respondents living in lower-income regions reported being less satisfied with their current housing situation and neighbourhood. This study has shown that both observable and unobservable factors are important determinants of residential location choice. It provides evidence that toll roads affect residential location preferences and that the influence varies with the distance to the toll gate, as well as among population groups in various income groups and regions.

\section{How do variations in Level of Service (LoS) of the Cipularang toll road and socio- economic attributes simultaneously affect residential location, route and mode choices across population segments?}

This question is discussed in Chapter 5. This research utilized stated and revealed preference data to investigate route and mode choices in response to the toll road's construction. This study adds to the literature by examining travel behaviour impacts across various population segments in response to a toll road's presence using the following three discrete choice models:

a. Mixed logit model with panel data to deal with both sequences of choices and intrinsic correlation among the choices;

b. Hybrid choice model, in which attitudes towards toll road and the travel are incorporated; and

c. Joint model, to identify self-selection by estimating residential location choice and travel behaviour simultaneously.

In Indonesia context, where numerous new toll roads are being operated in the past decade, no studies have investigated travel behaviour effects across population segments and the relation with residential location decision in greater detail.

The model estimation results show that, in general, the respondents preferred options that made use of the toll road. However, low-income individuals would select opt-out choices, allowing them to travel using the cheapest travel mode (train or motorcycle), in contrast with upperincome respondents who prefer to use toll roads. The respondents also perceived travel cost and travel time negatively. Low-income car drivers were found to be the most sensitive toward an increased travel cost among car users. Furthermore, bus users prefer to choose alternatives without toll roads. People who travel for work and need to pay for the trip themselves value options without the toll roads. Other variables, such as age, gender, trip purpose, and trip frequency, also were found to have a significant influence on route choice and mode choice.

Not surprisingly, the results of the modelling effort show that a positive attitude toward the current mode and the toll road will result in people travelling via the toll road and continuing to use the same mode. Remarkably, respondents who lived farther than $5 \mathrm{~km}$ from the toll gate also perceive the toll road positively. Moreover, although bus users prefer not to travel via the toll roads, they still perceive the toll road positively. Interestingly, it was further found that lowincome respondents have negative attitudes toward their current travel mode, although they still perceive the toll road positively.

Furthermore, route, mode and residential location choices were found to be associated through common parameters of distance to the toll gate, trip frequency, and income level. Respondents who live close to toll gates prefer to use the toll road are likely to stay in their current residence. Frequent users of the toll road would not choose the options without the toll road and tend to relocate. Low-income respondents also tend to relocate from their current housing. This implies dissatisfaction on their current situation, as also shown by their negative attitude toward the 
current mode, and would rather choose another situation. This association indicates the interaction between route and mode choices and residential location decisions.

\subsection{Policy implications}

The results of this research highlight potential implications for transport planning and urban planning, as well as for decision-makers at the relevant authorities. This research explored the direct and indirect impacts of toll road development by investigating regional accessibility and induced spatial development, incorporating effects on the behaviour of individuals with regard to residential and travel mobility.

With both direct and indirect impacts of toll road construction identified in this thesis, it challenges the paradigm of 'predict and provide', that is, the continual construction of transport infrastructure to meet the demand and solve short term traffic problem, such as congestion, without considering both indirect and induced supply effects. This paradigm is still widely used in transport planning, notably in developing countries. However, ideally, transport policy follows the decision-making cycle, in which needs or a rationale are identified first to define the objectives or the desired transport system or system level. Then, an ex-ante evaluation (appraisal) is conducted to identify possible transport policies or projects. Subsequent steps (monitoring, ex-post evaluation and feedback) after the policy has been implemented are often neglected. Ex-post evaluations are essential to assess the achieved outcome and identify induced effects of road projects.

In the appraisal of major transport investments, induced demand effects are often taken into account, while induced supply effects on local infrastructure are overlooked. Chapter 2 in this thesis found that induced supply effects could influence traffic flows, accessibility levels and thus the economic and social impacts of major road investments. In the Indonesian decentralised government system, local governments have the full authority to carry out local road projects. They should synchronise local road plans with the national road plan and anticipate any effects due to the construction of major national roads, such as the emergence of new activities and the increase in the size of the local population. The central government could consider induced supply effects in economic appraisals of toll roads by conducting sensitivity analyses.

The findings of this study urge the incorporation of accessibility planning into the policy practice. Accessibility planning underlines the integration of land use and transport planning with the goal of enabling all individuals, regardless of their social class or ability, to participate in any activities in the area by using the current transport system. It is a very important task of any transport system, as inequity in access is associated with income inequity and lower human capital.

Current transport project appraisals are mostly based on a project's economic evaluation (e.g. cost and benefit analysis), which is rooted in utilitarian theory. It assumes that the gains for wealthy people who benefit from the project can theoretically compensate for the lack of gains experienced by the poor, who cannot afford any extra costs or are unable to use the current transport service. However, transport policy should not only address economic efficiency, but also equity implications, particularly in developing countries.

In this thesis, I have shown how important it is to incorporate equity in transport evaluations. The Cipularang toll road has caused increased job competition as more workers are now able to access jobs available in the job-poor area in between Jakarta and Bandung (Chapter 3). This does not affect the overall spatial inequity, but low-income respondents prefer non-tolled road 
options, allowing them to travel using the cheapest travel mode (train or motorcycle), in contrast with higher-income respondents, who prefer to use toll roads (Chapter 5). With regard to longterm decisions, such as residential relocation, low-income respondents tend to want to relocate and are dissatisfied with their current housing (Chapter 4). On the other hand, high-income respondents are willing to pay higher land taxes to live closer than $5 \mathrm{~km}$ to the toll road to capture travel time benefits. Members of this population group also travel more frequently using the toll road. These findings indicate that people with higher incomes benefit stronger than individuals with lower incomes. In this thesis, I have also confirmed that controlling travel and socio-economic characteristics is essential to forecast the demand to travel via a toll road, as well as the revenues. A more integrated land use and transport approach is needed to enhance intended economic efficiency and reduce inequity caused by road projects.

\subsection{Direction for future research}

This section provides some directions for further research based on the limitations and findings reported in this thesis.

1. To improve the analysis of induced-supply effects of toll road construction, local road projects in a wider area (beyond the 18-km zone used in this study) can be looked at. In addition, the data used in the present research did not show which projects will be realised and which ones will not, since our study only considered road projects that had already been approved by the local government. There may be other factors, such as network-related variables (congestion, road capacity and current speed limitations), as well as the political agenda or national events that play a role in decision-making that are not part of our dataset and therefore were not captured by our models.

2. Insight into job accessibility effects due to new toll roads can be improved in several ways:

a. By estimating the job accessibility for different worker groups across job sectors, including informal sector jobs, and educational backgrounds. However, this was not possible in this study as sector-level employment data or detailed data on the working population are not available at a high spatial resolution for Indonesia.

b. By taking mode choice and availability of modes into account, as different income groups have different modes available. Low-income workers in developing countries often do not have access to a car. The inclusion of mode choice could affect the distribution of job accessibility significantly.

c. By controlling induced supply effects to be able to fully capture both direct and indirect effects of the toll road construction on job accessibility, as represented by the dashed lines in Figure 1.1. This was not possible in this research, as data about local road projects were limited.

3. From a methodological perspective, modelling of the residential location and travel behaviour can be enriched with the inclusion of GIS data related to built-environment factors, such as number of shops or public facilities in the neighbourhood. The inclusion of these built-environment factors would explain the perceived accessibility through the latent variable of satisfaction with neighbourhood included in the residential location choice model. 
4. Additional research should try to gain more insight into the influence of a major new road on the relocation of firms and their workers, and study the interdependencies between the relocation of firms and households. Firms that relocate to areas close to the road might search for workers nearby and can influence the relocation of its workers' households. This aspect is also essential for determining job accessibility.

5. Further research on the impacts of the Cipularang toll road should address on leisure / non-work trips, given that this trip purpose is important among users of this toll road. Non-work trips normally would have a smaller value of time than work trips. However, one can argue that since non-work trips are not common and can also be spontaneous, people might therefore like to pay more to be able to travel via the quickest route (Vrtic et al., 2010). The study of leisure trips via the toll road can be extended with an investigation of the leisure destinations, and thus, could also identify the extent of the impact of the toll road on the development of tourism in the region. 


\section{References}

Abraham, J., \& Hunt, J. (1997). Specification and estimation of nested logit model of home, workplaces, and commuter mode choices by multiple-worker households. Transportation Research Record, 1606(1), 17-24. doi:10.3141/1606-03

Adriani, Y. (2013). Urban Ecotourism to reduce tourism impact on air quality of Bandung City. ASEAN Journal on Hospitality Tourism, 12(1), 59-71.

Aljoufie, M., Zuidgeest, M., Brussel, M., \& van Maarseveen, M. (2013). Spatial-temporal analysis of urban growth and transportation in Jeddah City, Saudi Arabia. Cities, 31, $57-$ 68. doi:10.1016/j.cities.2012.04.008

Anas, A. (1981). The estimation of multinomial logit models of joint location and travel mode choice from aggregated data. Journal of Regional Science, 21(2), 223-242. doi:10.1111/j.1467-9787.1981.tb00696.x

Anas, R., Tamin, O., Tamin, R., \& Wibowo, S. (2017). Measuring regional economic impact of Cipularang toll road investments: using an input-output model (Case study: Bandung District). International Journal of Civil Engineering and Technology, 8(10).

Andani, I. G. A., La Paix Puello, L., \& Geurs, K. (2019). Effects of toll road construction on local road projects in Indonesia. Journal of Transport and Land Use, 12(1). doi:10.5198/jtlu.2019.1258

Ardiyono, S. K., Parenrengi, N. P. A., \& Faturachman, F. (2018). How does toll road impact accessibilities, trades, and investments in short term? A case study of Cipali toll road in West Java, Indonesia. 2018, Journal of Infrastructure, Policy and Development. doi:10.24294/jipd.v2i2.673 
Arentze, T., \& Timmermans, H. (2007). Congestion pricing scenarios and change of job or residential location: Results of a stated adaptation experiment. Journal of Transport Geography, 15(1), 56-61. doi:10.1016/j.jtrangeo.2006.02.013

Asian Development Bank, \& BPS. (2010). The Informal Sector and Informal Employment in Indonesia. Retrieved from https://www.adb.org/sites/default/files/publication/ 28438/informal-sector-indonesia.pdf

Atasoy, B., Glerum, A., \& Bierlaire, M. (2013). Attitudes towards mode choice in Switzerland. disP - The Planning Review, 49(2), 101-117. doi:10.1080/02513625.2013.827518

Avin, U., Cervero, R., Moore, T., \& Dorney, C. (2007). Forecasting indirect land use effects of transportation projects. NCHRP Project 25-25, Task 22, National Cooperative Highway Research Program, Transportation Research Board, 1-130.

Axhausen, K. W., Froelich, P., \& Tschopp, M. (2011). Changes in Swiss accessibility since 1850. Research in Transportation Economics, $31(1), \quad 72-80$. doi:10.1016/j.retrec.2010.11.010

Bahamonde-Birke, F. J., Kunert, U., Link, H., \& Ortúzar, J. D. D. (2015). About attitudes and perceptions: finding the proper way to consider latent variables in discrete choice models. Transportation, 42, 1-19. doi:10.1007/s11116-015-9663-5

Bahamonde-Birke, F. J., \& Ortúzar, J. d. D. (2017). Analyzing the continuity of attitudinal and perceptual indicators in hybrid choice models. Journal of Choice Modelling, 25, 28-39. doi:10.1016/j.jocm.2017.01.003

Bailey, N., \& Livingston, M. (2008). Selective migration and neighbourhood deprivation: evidence from 2001 census migration data for England and Scotland. Urban Studies, 45(4), 943-961. doi:10.1177/0042098007088475

Banerjee, A., Ye, X., \& Pendyala, R. M. (2007). Understanding travel time expenditures around the world: Exploring the notion of a travel time frontier. Transportation, 34(1), 51-65. doi:10.1007/s11116-006-0004-6

Banister, D. (2018). Inequality In Transport: Routledge, New York.

Banister, D., \& Berechman, Y. (2001). Transport investment and the promotion of economic growth. Journal of Transport Geography, 9(3), 209-218. doi:10.1016/S09666923(01)00013-8

Baum-Snow, N. (2007). Did highways cause suburbanization? The Quarterly Journal of Economics, 122(2), 775-805. doi:10.1162/qjec.122.2.775

Belgiawan, P. F., Ilahi, A., \& Axhausen, K. W. (2018). Influence of pricing on mode choice decision in Jakarta: A random regret minimization model. Case Studies on Transport Policy. doi:10.1016/j.cstp.2018.12.002

Ben-Akiva, M., McFadden, D., Train, K., Walker, J., Bhat, C., Bierlaire, M., . . Bunch, D. S. (2002). Hybrid choice models: progress and challenges. Marketing letters, 13(3), 163-175. doi:10.1023/A:1020254301302 
Ben-Akiva, M. E., \& Lerman, S. R. (1985). Discrete choice analysis: theory and application to travel demand (Vol. 9): MIT press.

Bhat, C. R., \& Guo, J. Y. (2007). A comprehensive analysis of built environment characteristics on household residential choice and auto ownership levels. Transportation Research Part B: Methodological, 41(5), 506-526. doi:10.1016/j.trb.2005.12.005

Bierlaire, M. (2016). PythonBiogeme: a short introduction (Report TRANSP-OR 160706). Retrieved from Transport and Mobility Laboratory, ENAC, EPFL: https://transpor.epfl.ch/documents/technicalReports/Bier16a.pdf

Bierlaire, M. (2017). Calculating indicators with Biogeme (Report TRANSP-OR 170517). Retrieved from http://transp-or.epfl.ch/documents/technicalReports/Bier17.pdf

Boarnet, M. G. (1996). The direct and indirect economic effects of transportation infrastructure. UC Berkeley: University of California Transportation Center. Retrieved from http://www.escholarship.org/uc/item/1506r290

Bocarejo, J. P., \& Oviedo, D. R. (2012). Transport accessibility and social inequities: a tool for identification of mobility needs and evaluation of transport investments. Journal of Transport Geography, 24, 142-154. doi:10.1016/j.jtrangeo.2011.12.004

Bocarejo, J. P., Portilla, I. J., Velásquez, J. M., Cruz, M. N., Peña, A., \& Oviedo, D. R. (2014). An innovative transit system and its impact on low income users: the case of the Metrocable in Medellín. Journal of Transport Geography, 39, 49-61. doi:10.1016/j.jtrangeo.2014.06.018

Böheim, R., \& Taylor, M. P. (2002). Tied down or room to move? Investigating the relationships between housing tenure, employment status and residential mobility in Britain. Scottish Journal of Political Economy, 49(4), 369-392. doi:10.1111/14679485.00237

Börjesson, M., Eliasson, J., Hugosson, M. B., \& Brundell-Freij, K. (2012). The Stockholm congestion charges - 5 years on. Effects, acceptability and lessons learnt. Transport Policy, 20, 1-12. doi:10.1016/j.tranpol.2011.11.001

BPJT. (2018). Jalan tol beroperasi (in Indonesian) [Operated toll toads]. Retrieved from http://bpjt.pu.go.id/konten/progress/beroperasi

BPS. (2013). Provinsi Jawa Barat dalam Angka 2013 (in Indonesian) [West Java Province in Figures 2013]. Retrieved from https://jabar.bps.go.id/publication/2013/11/08/ 608dc2f5d0680ca167c6e30a/jawa-barat-dalam-angka-2013.html

BPS. (2015). Survei Angkatan Kerja Nasional (in Indonesian) [National Labour Force Survey]. Retrieved from https://mikrodata.bps.go.id/mikrodata/index.php/catalog/689

BPS. (2017a). Provinsi Jawa Barat dalam Angka 2017 (in Indonesian) [West Java Province in Figures 2017]. Retrieved from https://jabar.bps.go.id/publication/2017/08/12/ $\underline{62379 \mathrm{e} 17 \mathrm{bcc} 20052 \mathrm{a} 7991 \mathrm{~d} 35 / \text { provinsi-jawa-barat-dalam-angka-2017.html }}$

BPS. (2017b). Rata-rata Pendapatan Bersih Sebulan Pekerja Bebas Menurut Provinsi dan Pendidikan Tertinggi yang Ditamatkan (ribu rupiah), 2016 (in Indonesian) [Average 
Monthly Net Income of Workers by Province and Education Level (in thousand rupiahs), 2016]. Retrieved from https://www.bps.go.id/statictable/2016/12/19/1956/rata-ratapendapatan-bersih-pekerja-bebas-menurut-provinsi-dan-pendidikan-tertinggi-yangditamatkan-ribu-rupiah-2016.html

BPS. (2018). Rata-Rata Pengeluaran per Kapita Sebulan di Daerah Perkotaan dan Perdesaan Menurut Provinsi dan Kelompok Barang (rupiah), 2011-2017 (in Indonesian) [Average Monthly per capita Expenditures in Cities and Rural Areas by Province and Goods (rupiah), 2011-2017]. Retrieved from https://www.bps.go.id/statictable/2014/09/08/945/rata-ratapengeluaran-per-kapita-sebulan-di-daerah-perkotaan-dan-perdesaan-menurut-provinsidan-kelompok-barang-rupiah-2011-2017.html

Cao, X., Xu, Z., \& Fan, Y. (2010). Exploring the connections among residential location, selfselection, and driving: Propensity score matching with multiple treatments. Transportation Research Part A: Policy and Practice, 44(10), 797-805. doi:10.1016/j.tra.2010.07.010

Cervero, R. (1998). The transit metropolis: a global inquiry: Island press.

Cervero, R., \& Hansen, M. (2002). Induced travel demand and induced road investment: a simultaneous equation analysis. Journal of Transport Economics and Policy (JTEP), 36(3), 469-490. Retrieved from https://www.ingentaconnect.com/content/lse/jtep/ 2002/00000036/00000003/art00005\#

Cervero, R., \& Murakami, J. (2010). Effects of built environments on vehicle miles traveled: Evidence from 370 US urbanized areas. Environment and Planning A: Economy and Space, 42(2), 400-418. doi:10.1068/a4236

Chen, D. J., \& Wen, Y. H. (2014). Effects of freeway mileage-based toll scheme on the shortrange driver's route choice behavior. Journal of Urban Planning and Development, 140(2). doi:10.1061/(ASCE)UP.1943-5444.0000167

Chen, J., Chen, C., \& Timmermans, H. (2008). Accessibility trade-offs in household residential location decisions. Transportation Research Record, 2077(1), 71-79. doi:10.3141/2077-10

Chen, L., Zhang, W., Yang, Y., \& Yu, J. (2013). Disparities in residential environment and satisfaction among urban residents in Dalian, China. Habitat International, 40, 100-108. doi:10.1016/j.habitatint.2013.03.002

Cheng, J., \& Bertolini, L. (2013). Measuring urban job accessibility with distance decay, competition and diversity. Journal of Transport Geography, 30, 100-109. doi:10.1016/j.jtrangeo.2013.03.005

Cherchi, E., \& Ortúzar, J. (2002). Mixed RP/SP models incorporating interaction effects. Transportation, 29(4), 371-395. doi:10.1023/A:1016307308723

Chi, G. (2010). The impacts of highway expansion on population change: An integrated spatial approach. Rural Sociology, 75(1), 58-89. doi:10.1111/j.1549-0831.2009.00003.x

Chi, G. (2012). The impacts of transport accessibility on population change across rural, suburban and urban areas: a case study of Wisconsin at sub-county levels. Urban Studies, 49(12), 2711-2731. Retrieved from 10.1177/0042098011431284 
Choudhury, C. F., \& Ayaz, S. B. (2015). Why live far? - Insights from modeling residential location choice in Bangladesh. Journal of Transport Geography, 48, 1-9. doi:10.1016/j.jtrangeo.2015.08.001

Clark, W. A. (2013). Life course events and residential change: unpacking age effects on the probability of moving. Journal of Population Research, 30(4), 319-334. doi:10.1007/s12546-013-9116-y

Clark, W. A., \& Onaka, J. L. (1983). Life cycle and housing adjustment as explanations of residential mobility. Urban Studies, 20(1), 47-57. doi:10.1080/713703176

Dalvi, M. Q., \& Martin, K. (1976). The measurement of accessibility: some preliminary results. Transportation, 5(1), 17-42. doi:10.1007/BF00165245

de Palma, A., \& Lindsey, R. (2006). Modelling and evaluation of road pricing in Paris. Transport Policy, 13(2), 115-126. doi:10.1016/j.tranpol.2005.11.013

de Palma, A., Motamedi, K., Picard, N., \& Waddell, P. (2005). A model of residential location choice with endogenous housing prices and traffic for the Paris region. European Transport /Trasporti Europei, XI(31), 67-82. Retrieved from http://hdl.handle.net/10077/5884

De Vos, J., Ettema, D., \& Witlox, F. (2018). Changing travel behaviour and attitudes following a residential relocation. Journal of Transport Geography, 73, 131-147. doi:10.1016/j.jtrangeo.2018.10.013

Di Ciommo, F., \& Lucas, K. (2014). Evaluating the equity effects of road-pricing in the European urban context - The Madrid Metropolitan Area. Applied Geography, 54, 74-82. doi:10.1016/j.apgeog.2014.07.015

Di Ciommo, F., \& Shiftan, Y. (2017). Transport equity analysis. Transport Reviews, 37(2), 139151. doi:10.1080/01441647.2017.1278647

Dorodjatoen, A. M. H. (2009). The emergence of Jakarta-Bandung mega-urban region and its future challenges. Jurnal Perencanaan Wilayah dan Kota, 20(1), 15-33. Retrieved from http://journals.itb.ac.id/index.php/jpwk/article/view/4164

Downs, A. (2000). Stuck in traffic: Coping with peak-hour traffic congestion: Brookings Institution Press.

Duranton, G., \& Turner, M. A. (2011). The fundamental law of road congestion: Evidence from US cities. The American Economic Review, 101(6), 2616-2652. doi:10.1257/aer.101.6.2616

Eliasson, J., Börjesson, M., Odeck, J., \& Welde, M. (2015). Does benefit and cost efficiency influence transport investment decisions? Journal of transport economics and policy, 49(3), 377-396. Retrieved from http://www.ingentaconnect.com/content/lse/jtep/2015/ $\underline{00000049 / 00000003 / \operatorname{art} 00002}$

Eliasson, J., \& Lundberg, M. (2012). Do cost-benefit analyses influence transport investment decisions? Experiences from the Swedish Transport Investment Plan 2010-21. Transport Reviews, 32(1), 29-48. doi:10.1080/01441647.2011.582541 
Eliasson, J., \& Mattsson, L.-G. (2001). Transport and location effects of road pricing: A simulation approach. Journal of Transport Economics Policy, 35(3), 417-456. Retrieved from https://www.ingentaconnect.com/content/lse/jtep/2001/00000035/00000003/art 00005

Eliasson, J., \& Mattsson, L.-G. (2006). Equity effects of congestion pricing: Quantitative methodology and a case study for Stockholm. Transportation Research Part A: Policy and Practice, 40(7), 602-620. doi:10.1016/j.tra.2005.11.002

Eluru, N., Pinjari, A., Guo, J., Sener, I., Srinivasan, S., Copperman, R., \& Bhat, C. (2008). Population updating system structures and models embedded in the comprehensive econometric microsimulator for urban systems. Transportation Research Record, 2076(1), 171-182. doi:10.3141/2076-19

Ettema, D., \& Nieuwenhuis, R. (2017). Residential self-selection and travel behaviour: What are the effects of attitudes, reasons for location choice and the built environment? Journal of Transport Geography, 59, 146-155. doi:10.1016/j.jtrangeo.2017.01.009

Fan, Y., Guthrie, A., \& Levinson, D. M. (2010). Impact of light rail implementation on labor market accessibility: A transportation equity perspective. doi:10.5198/jtlu.v5i3.240

Firman, T. (2009). The continuity and change in mega-urbanization in Indonesia: A survey of Jakarta-Bandung Region (JBR) development. Habitat International, 33(4), 327-339. doi:10.1016/j.habitatint.2008.08.005

Forslund, U. M., \& Johansson, B. (1995). Assessing road investments: accessibility changes, cost benefit and production effects. The Annals of Regional Science, 29(2), 155-174. doi:10.1007/BF01581804

Frenkel, A., Bendit, E., \& Kaplan, S. (2013). Residential location choice of knowledgeworkers: The role of amenities, workplace and lifestyle. Cities, 35, 33-41. doi:10.1016/j.cities.2013.06.005

Fridstrom, L. (1999). Econometric models of road use, accidents, and road investment decisions (Report 457). Retrieved from Institute of Transport Economics, Oslo: https://www.toi.no/getfile.php?mmfileid=6030

Fridstrom, L., \& Elvik, R. (1997). The barely revealed preference behind road investment priorities. Public Choice, 92(1-2), 145-168. doi:10.1023/A:1004954816965

Galster, G. C., \& Hesser, G. W. (1981). Residential Satisfaction:Compositional and Contextual Correlates. Environment and Behavior, 13(6), 735-758. doi:10.1177/0013916581136006

Geurs, K., \& Ritsema van Eck, J. (2001). Accessibility measures: review and applications. Evaluation of accessibility impacts of land-use transportation scenarios, and related social and economic impact (RIVM report 408505 006). Retrieved from http://hdl.handle.net/10029/259808

Geurs, K., \& van Eck, J. R. R. (2003). Evaluation of accessibility impacts of land-use scenarios: The implications of job competition, land-use, and infrastructure developments for The Netherlands. Environment and Planning B: Planning and Design, 30(1), 69-87. doi:10.1068/b12940 
Geurs, K. T., \& van Wee, B. (2004). Accessibility evaluation of land-use and transport strategies: review and research directions. Journal of Transport Geography, 12(2), 127 140. doi:10.1016/j.jtrangeo.2003.10.005

Ghani, E., Goswami, A. G., \& Kerr, W. R. (2012). Highway to success: The impact of the Golden Quadrilateral project for the location and performance of Indian manufacturing. Retrieved from

Gini, C. (1936). On the measure of concentration with special reference to income and statistics. Colorado College Publication, General Series, 208, 73-79.

Gobillon, L., \& Wolff, F.-C. (2011). Housing and location choices of retiring households: Evidence from France. Urban Studies, 48(2), 331-347. doi:10.1177/0042098010363493

Golub, A., \& Martens, K. (2014). Using principles of justice to assess the modal equity of regional transportation plans. Journal of Transport Geography, 41, 10-20. doi:10.1016/j.jtrangeo.2014.07.014

Goode, F. M., \& Hastings, S. E. (1989). The effect of transportation service on the location of manufacturing plants in nonmetropolitan and small metropolitan communities. In W. R. Gillis (Ed.), Profitability and Mobility in Rural America: Successful Approaches to Tackling Rural Transportation Problems. Pennsylviania: Pennsylviania State University Press.

Grengs, J. (2010). Job accessibility and the modal mismatch in Detroit. Journal of Transport Geography, 18(1), 42-54. doi:10.1016/j.jtrangeo.2009.01.012

Grengs, J. (2012). Equity and the social distribution of job accessibility in Detroit. Environment and Planning B: Planning and Design, 39(5), 785-800. doi:10.1068/b36097

Guo, J., Feng, T., \& Timmermans, H. J. P. (2018). Modeling co-dependent choice of workplace, residence and commuting mode using an error component mixed logit model. Transportation. doi:10.1007/s11116-018-9927-y

Guzman, L. A., \& Oviedo, D. (2018). Accessibility, affordability and equity: Assessing 'propoor' public transport subsidies in Bogotá. Transport Policy, 68, 37-51. doi:10.1016/j.tranpol.2018.04.012

Habib, K. M. N., Kattan, L., \& Islam, M. T. (2011). Model of personal attitudes towards transit service quality. Journal of Advanced Transportation, 45(4), 271-285. doi:10.1002/atr.106

Habib, M., \& Miller, E. (2009). Reference-dependent residential location choice model within a relocation context. Transportation Research Record, 2133, 92-99. doi:10.3141/2133-10

Hamersma, M., Tillema, T., Sussman, J., \& Arts, J. (2014). Residential satisfaction close to highways: The impact of accessibility, nuisances and highway adjustment projects. Transportation Research Part A: Policy and Practice, 59, 106-121. doi:10.1016/j.tra.2013.11.004

Handy, S., Cao, X., \& Mokhtarian, P. (2005). Correlation or causality between the built environment and travel behavior? Evidence from Northern California. Transportation 
Research Part D: Transport and Environment, 10(6), 427-444. doi:10.1016/j.trd.2005.05.002

Hansen, M., \& Huang, Y. (1997). Road supply and traffic in California urban areas. Transportation Research Part A: Policy and Practice, 31(3), 205-218. doi:10.1016/S09658564(96)00019-5

Hansen, W. G. (1959). How accessibility shapes land use. Journal of the American Institute of Planners, 25(2), 73-76. doi:10.1080/01944365908978307

Haugen, K., Holm, E., Strömgren, M., Vilhelmson, B., \& Westin, K. (2012). Proximity, accessibility and choice: A matter of taste or condition? Papers in Regional Science, 91(1), 65-84. doi:10.1111/j.1435-5957.2011.00374.x

Herwangi, Y., Pradono, P., Syabri, I., \& Kustiwan, I. (2015). Making the connection between transport disadvantage and motorcycle usage of low-income people in Yogyakarta urbanized area, Indonesia. Journal of the Eastern Asia Society for Transportation Studies, 11, 90-109. doi:10.11175/easts.11.90

Hicks, J. (1939). The foundations of welfare economics. The Economic Journal, 49(196), 696712. doi: $10.2307 / 2225023$

Hipp, J. R. (2010). A dynamic view of neighborhoods: The reciprocal relationship between crime and neighborhood structural characteristics. Social Problems, 57(2), 205-230. doi:10.1525/sp.2010.57.2.205

Holl, A. (2007). Twenty years of accessibility improvements. The case of the Spanish motorway building programme. Journal of Transport Geography, 15(4), 286-297. doi:10.1016/j.jtrangeo.2006.09.003

Hurtubia, R., Atasoy, B., Glerum, A., Curchod, A., \& Bierlaire, M. (2010). Considering latent attitudes in mode choice: The case of switzerland. In World Conference on Transport Research.

Huu Phe, H., \& Wakely, P. (2000). Status, quality and the other trade-off: Towards a new theory of urban residential location. Urban Studies, 37(1), 7-35. doi:10.1080/0042098002276

Ingram, D. R. (1971). The concept of accessibility: a search for an operational form. Regional Studies, 5(2), 101-107. doi:10.1080/09595237100185131

Jarass, J., \& Scheiner, J. (2018). Residential self-selection and travel mode use in a new innercity development neighbourhood in Berlin. Journal of Transport Geography, 70, 68-77. doi:https://doi.org/10.1016/j.jtrangeo.2018.05.018

Ji, W., Wang, Y., Zhuang, D., Song, D., Shen, X., Wang, W., \& Li, G. (2014). Spatial and temporal distribution of expressway and its relationships to land cover and population: A case study of Beijing, China. Transportation Research Part D: Transport and Environment, 32, 86-96. doi:http://dx.doi.org/10.1016/j.trd.2014.07.010

JICA, \& BAPPENAS. (2004). The study on integrated transportation master plan for Jabodetabek (Phase 2). Retrieved from http://open_jicareport.jica.go.jp/710/ 710/710_108_11763885.html 
Johansen, F. (1989). Toll road characteristics and toll road experience in selected South East Asia countries. Transportation Research Part A: Policy and Practice, 23(6), 463-466. doi:10.1016/0191-2607(89)90067-8

Johansson, M. V., Heldt, T., \& Johansson, P. (2006). The effects of attitudes and personality traits on mode choice. Transportation Research Part A: Policy and Practice, 40(6), $507-$ 525. doi:10.1016/j.tra.2005.09.001

Kaldor, N. (1939). Welfare propositions of economics and interpersonal comparisons of utility. The Economic Journal, 49(1939), 549-552. doi:10.2307/2224835

Kan, K. (2007). Residential mobility and social capital. Journal of Urban Economics, 61(3), 436-457. doi:10.1016/j.jue.2006.07.005

Kayser, H. A. (2000). Gasoline demand and car choice: estimating gasoline demand using household information. Energy economics, 22(3), 331-348. doi:10.1016/S01409883(99)00043-2

Kim, J. H., Pagliara, F., \& Preston, J. (2005). The intention to move and residential location choice behaviour. Urban Studies, 42(9), 1621-1636. doi:10.1080/00420980500185611

Kitrinou, E., Polydoropoulou, A., \& Bolduc, D. (2010). Development of integrated choice and latent variable (ICLV) models for the residential relocation decision in island areas. In Stephane Hess \& A. Daly (Eds.), Choice Modelling: The State-of-the-art and The State-ofpractice: Proceedings from the Inaugural International Choice Modelling Conference (pp. 593-618): Emerald Group Publishing Limited.

Knorr, F., Chmura, T., \& Schreckenberg, M. (2014). Route choice in the presence of a toll road: The role of pre-trip information and learning. Transportation Research Part F: Traffic Psychology and Behaviour, 27(PA), 44-55. doi:10.1016/j.trf.2014.09.003

Kortum, K., Paleti, R., Bhat, C., \& Pendyala, R. (2012). Joint model of residential relocation choice and underlying causal factors. Transportation Research Record, 2303(1), 28-37. doi:10.3141/2303-04

Kotavaara, O., Antikainen, H., \& Rusanen, J. (2011). Population change and accessibility by road and rail networks: GIS and statistical approach to Finland 1970-2007. Journal of Transport Geography, 19(4), 926-935. doi:j.jtrangeo.2010.10.013

Kumarage, A. S. (2005). Impact of transport infrastructure \& services on urban poverty and land development: A case study - Colombo, Sri Lanka. Land and Urban Policies for Poverty Reduction, 117.

Kwan, M. P. (1998). Space-time and integral measures of individual accessibility: a comparative analysis using a point-based framework. Geographical analysis, 30(3), 191216. doi:10.1111/j.1538-4632.1998.tb00396.x

La Paix, L., Bierlaire, M., Cherchi, E., \& Monzón, A. (2013). How urban environment affects travel behaviour: integrated choice and latent variable model for travel schedules. In Stephane Hess \& A. Daly (Eds.), Choice Modelling: The State of the Art and the State of Practice (pp. 211-227): Edward Elgar. 
La Paix Puello, L. (2012). Modelling the impact of built environment, geographical scales and latent constructs on individual travel behaviour. (Doctoral thesis), Universidad Politécnica de Madrid, Madrid. Retrieved from http://oa.upm.es/10717/

La Paix Puello, L., Olde-Kalter, M.-J., \& Geurs, K. T. (2017). Measurement of non-random attrition effects on mobility rates using trip diaries data. Transportation Research Part A: Policy and Practice, 106, 51-64. doi:10.1016/j.tra.2017.09.002

Lee, B. H. Y., \& Waddell, P. (2010). Residential mobility and location choice: a nested logit model with sampling of alternatives. Transportation, 37(4), 587-601. doi:10.1007/s11116010-9270-4

Lerman, S. R. (1976). Location, housing, automobile ownership, and mode to work: a joint choice model. Transportation Research Record, 610(1), 6-11. doi:https://trid.trb.org/view/53665

Levinson, D., \& Karamalaputi, R. (2003). Induced supply: a model of highway network expansion at the microscopic level. Journal of Transport Economics and Policy (JTEP), 37(3), 297-318.

Li, M. Z. F., Lau, D. C. B., \& Seah, D. W. M. (2011). Car ownership and urban transport demand in Singapore. International Journal of Transport Economics, 38(1), 47-70. Retrieved from http://www.jstor.org/stable/42747909

Liao, F. H., Farber, S., \& Ewing, R. (2015). Compact development and preference heterogeneity in residential location choice behaviour: A latent class analysis. Urban Studies, 52(2), 314-337. doi:10.1177/0042098014527138

Limbumba, T. M. (2010). Exploring social-cultural explanations for residential location choices: The case of an African city-Dar es Salaam. (Doctoral thesis), KTH - Royal Institute of Technology, Stockholm, Sweden. Retrieved from http://www.divaportal.org/smash/get/diva2:302681/FULLTEXT01.pdf

Lin, T., Wang, D., \& Guan, X. (2017). The built environment, travel attitude, and travel behavior: Residential self-selection or residential determination? Journal of Transport Geography, 65, 111-122. doi:10.1016/j.jtrangeo.2017.10.004

Lin, X., Susilo, Y. O., Shao, C., \& Liu, C. (2018). The implication of road toll discount for mode choice: Intercity travel during the chinese spring festival holiday. Sustainability, 10(8). doi:10.3390/su10082700

Litman, T. (2015). Evaluating transportation equityWorld Transport Policy \& Practice (Vol. 8 , pp. 50-65).

Louviere, J. J., \& Hensher, D. A. (1983). Using discrete choice models with experimental design data to forecast consumer demand for a unique cultural event. Journal of Consumer research, 10(3), 348-361.

Louviere, J. J., Hensher, D. A., \& Swait, J. D. (2000). Stated choice methods: analysis and applications: Cambridge University Press. 
Lubis, H. A.-R. S., Armijaya, H., \& Dharmowijoyo, D. B. (2005). The competition of passenger transport modes along Jakarta-Bandung corridor. In Proceedings of The Eastern Asia Society for Transportation Studies (Vol. 5, pp. 75-89).

Lucas, K. (2012). Transport and social exclusion: Where are we now? Transport Policy, 20, 105-113. doi:10.1016/j.tranpol.2012.01.013

Lucas, K., van Wee, B., \& Maat, K. (2016). A method to evaluate equitable accessibility: combining ethical theories and accessibility-based approaches. Transportation, 43(3), 473490. doi:10.1007/s11116-015-9585-2

Luo, W., \& Qi, Y. (2009). An enhanced two-step floating catchment area (E2SFCA) method for measuring spatial accessibility to primary care physicians. Health \& Place, 15(4), 11001107. doi:10.1016/j.healthplace.2009.06.002

Mejía, D., \& St-Pierre, M. (2008). Unequal opportunities and human capital formation. Journal of Development Economics, 86(2), 395-413. doi:10.1016/j.jdeveco.2007.04.001

Molin, E., \& Timmermans, H. (2003). Transport considerations in residential choice decisions: Accumulated evidence from the Benelux. In Proceedings 82nd Annual Meeting of the Transportation Research Board (pp. 03-2142).

Mouter, N. (2017). Dutch politicians' use of cost-benefit analysis. Transportation, 44(5), 11271145. doi:10.1007/s11116-016-9697-3

Mulder, C. H., \& Cooke, T. J. (2009). Family ties and residential locations. Population, space and place, 15(4), 299-304. doi:10.1002/psp.556

Müller, K., Steinmeier, C., \& Küchler, M. (2010). Urban growth along motorways in $\begin{array}{llll}\text { Switzerland. } \quad \text { Landscape and } & \text { 3-12. }\end{array}$ doi:10.1016/j.landurbplan.2010.07.004

Musso, A., Piccioni, C., Tozzi, M., Godard, G., Lapeyre, A., \& Papandreou, K. (2013). Road transport elasticity: How fuel price changes can affect traffic demand on a toll motorway. Procedia - Social and Behavioral Sciences, 87, 85-102. doi:10.1016/j.sbspro.2013.10.596

Nellthorp, J., \& Mackie, P. (2000). The UK Roads Review-a hedonic model of decision making. Transport Policy, 7(2), 127-138. doi:10.1016/S0967-070X(00)00002-0

Neutens, T., Schwanen, T., Witlox, F., \& De Maeyer, P. (2010). Equity of urban service delivery: a comparison of different accessibility measures. Environment and Planning A, 42(7), 1613. doi:10.1068/a4230

Nielsen, O. A. (2004). Behavioral responses to road pricing schemes: Description of the Danish AKTA experiment. Intelligent Transportation Systems, 8(4), 233-251. doi:10.1080/15472450490495579

Nilsson, J.-E. (1991). Investment decisions in a public bureaucracy: a case study of Swedish road planning practices. Journal of transport economics and policy, 163-175. Retrieved from https://www.jstor.org/stable/20052952 
Nurlaela, S., \& Curtis, C. (2012). Modeling household residential location choice and travel behavior and its relationship with public transport accessibility. Procedia-Social and Behavioral Sciences, 54, 56-64. doi:10.1016/j.sbspro.2012.09.725

Nyborg, K. (1998). Some Norwegian politicians' use of cost-benefit analysis. Public Choice, 95(3-4), 381-401. doi:10.1023/A:1005012509068

Oakil, A., Ettema, D., Arentze, T., \& Timmermans, H. (2011). A longitudinal analysis of the dependence of the commute mode switching decision on mobility decisions and life cycle events. In Proceedings of the 16th International Conference of Hong Kong Society for Transportation Studies. Hong Kong: Hong Kong Society for Transportation Studies.

Odeck, J. (1996). Ranking of regional road investment in Norway. Transportation, 23(2), 123140. doi:10.1007/BF00170032

Odeck, J. (2010). What determines decision-makers' preferences for road investments? Evidence from the Norwegian road sector. Transport Reviews, 30(4), 473-494. doi:10.1080/01441640903138640

Odeck, J., \& Bråthen, S. (2008). Travel demand elasticities and users attitudes: A case study of Norwegian toll projects. Transportation Research Part A: Policy and Practice, 42(1), 7794. doi:10.1016/j.tra.2007.06.013

Olaru, D., Smith, B., \& Taplin, J. H. (2011). Residential location and transit-oriented development in a new rail corridor. Transportation Research Part A: Policy and Practice, 45(3), 219-237. doi:10.1016/j.tra.2010.12.007

OpenStreetMap contributors. (2016). OpenStreetMap. Retrieved from https://www.openstreetmap.org/

Ozturk, E., \& Irwin, E. G. (2001). Explaining household location choices using a spatial probit model. Paper presented at the 2001 Annual Meeting American Agricultural Economics Association, Chicago, IL. https://ideas.repec.org/p/ags/aaea01/20626.html

Paleti, R., Bhat, C. R., \& Pendyala, R. M. (2013). Integrated model of residential location, work location, vehicle ownership, and commute tour characteristics. Transportation Research Record, 2382(1), 162-172. doi:10.3141/2382-18

Palma, J. G. (2011). Homogeneous middles vs. heterogeneous tails, and the end of the 'invertedU': It's all about the share of the rich. Development and change, 42(1), 87-153. doi:10.1111/j.1467-7660.2011.01694.x

Papinski, D., Scott, D. M., \& Doherty, S. T. (2009). Exploring the route choice decision-making process: A comparison of planned and observed routes obtained using person-based GPS. Transportation Research Part F: Traffic Psychology and Behaviour, 12(4), 347-358. doi:10.1016/j.trf.2009.04.001

Peirson, J., \& Vickerman, R. (2008). The London congestion charging scheme: the evidence. In C. Jensen-Butler, B. Sloth, M. M. Larsen, B. Madsen, \& O. A. Nielsen (Eds.), Road Pricing, the Economy and the Environment (pp. 79-91). Berlin, Heidelberg: Springer Berlin Heidelberg. 
Pereira, R., Schwanen, T., \& Banister, D. (2016). Distributive justice and equity in transportation. Transport Reviews, 37(2), 170-191. doi:10.1080/01441647.2016.1257660

Pieters, M., \& Zondag, B. (2005). Influence of accessibility on residential location choice. Transportation Research Record, 1902(1), 63-70. doi:10.1177/0361198105190200108

Pinjari, A. R., Pendyala, R. M., Bhat, C. R., \& Waddell, P. A. (2011). Modeling the choice continuum: an integrated model of residential location, auto ownership, bicycle ownership, and commute tour mode choice decisions. Transportation, 38(6), 933.

Prahara, E., Suangga, M., \& Ansori, A. L. (2018). Analysis of potential diverted of passenger car to the new toll road (case study: Cileunyi - Sumedang, West Java). In IOP Conference Series: Earth and Environmental Science (Vol. 109): IOP Publishing.

Prashker, J., Shiftan, Y., \& Hershkovitch-Sarusi, P. (2008). Residential choice location, gender and the commute trip to work in Tel Aviv. Journal of Transport Geography, 16(5), 332341. doi:10.1016/j.jtrangeo.2008.02.001

Pritchard, J. P., Tomasiello, D., Giannoti, M., \& Geurs, K. (2019). An international comparison of equity in accessibility to jobs: London, Sao Paulo and the Randstad. Submitted to Transport Findings (under review).

Ramjerdi, F. (2006). Equity measures and their performance in transportation. Transportation Research Record, 1983(1), 67-74. doi:10.1177/0361198106198300110

Rapidis. (2018). Traffic Analyst for ArcGIS. Retrieved from http://www.rapidis.com/trafficanalyst-arcgis/?lang=en

Rephann, T., \& Isserman, A. (1994). New highways as economic development tools: An evaluation using quasi-experimental matching methods. Regional Science and Urban Economics, 24(6), 723-751. doi:10.1016/0166-0462(94)90009-4

Rinaldi, S. M., Peerenboom, J. P., \& Kelly, T. K. (2001). Identifying, understanding, and analyzing critical infrastructure interdependencies. IEEE Control Systems, 21(6), 11-25. doi:10.1109/37.969131

Roson, R. (2001). Assessing the option value of a publicly provided service: The case of local transport. Urban Studies, 38(8), 1319-1327.

Rothenberg, A. D., Gaduh, A., Burger, N. E., Chazali, C., Tjandraningsih, I., Radikun, R., . . . Weilant, S. (2016). Rethinking Indonesia's informal sector. World Development, 80, 96113. doi:10.1016/j.worlddev.2015.11.005

Salon, D. (2006). Cars and the city: an investigation of transportation and residential location choices in New York City. (Doctoral thesis), University of California Berkeley Davis. Retrieved from https://escholarship.org/uc/item/1br223vz

Schwarz, G. (1978). Estimating the dimension of a model. The annals of statistics, 6(2), 461464. Retrieved from https://projecteuclid.org/euclid.aos/1176344136 
Sharma, A., \& Chandrasekhar, S. (2014). Growth of the urban shadow, spatial distribution of economic activities, and commuting by workers in rural and urban India. World Development, 61, 154-166. doi:10.1016/j.worlddev.2014.04.003

Shen, Q. (1998). Location Characteristics of Inner-City Neighborhoods and Employment Accessibility of Low-Wage Workers. Environment and Planning B: Planning and Design, 25(3), 345-365. doi:10.1068/b250345

Shirzadi Babakan, A., \& Taleai, M. (2015). Impacts of transport development on residence choice of renter households: An agent-based evaluation. Habitat International, 49, 275285. doi:10.1016/j.habitatint.2015.05.033

Smith, B., \& Olaru, D. (2013). Lifecycle stages and residential location choice in the presence of latent preference heterogeneity. Environment and Planning A: Economy and Space, 45(10), 2495-2514. doi:10.1068/a45490

Speare, A. (1974). Residential satisfaction as an intervening variable in residential mobility. Demography, 11(2), 173-188. doi:10.2307/2060556

Stepniak, M., \& Rosik, P. (2013). Accessibility improvement, territorial cohesion and spillovers: a multidimensional evaluation of two motorway sections in Poland. Journal of Transport Geography, 31, 154-163. doi:10.1016/j.jtrangeo.2013.06.017

Susilo, Y. O., Tjoewono, T. B., Santosa, W., \& Parikesit, D. (2007). A reflection of motorization and public transport in Jakarta metropolitan area: Lessons learned and future implications towards better transportation development in developing countries. Journal of the Eastern Asia Society for Transportation Studies, 7, 299-314. doi:10.11175/easts.7.299

Tillema, T. (2007). Road pricing: a transport geographical perspective. Geographical accessibility and short and long-term behavioural effects. (Doctoral thesis), Utrecht University, Retrieved from https://dspace.library.uu.nl/handle/1874/19611

Tillema, T., van Wee, B., \& Ettema, D. (2010). The influence of (toll-related) travel costs in residential location decisions of households: A stated choice approach. Transportation Research Part A: Policy and Practice, 44(10), 785-796. doi:10.1016/j.tra.2010.07.009

Train, K. E. (2009). Discrete choice methods with simulation (2nd ed.). New York: Cambridge University Press.

Tran, M. T., Zhang, J., Chikaraishi, M., \& Fujiwara, A. (2016). A joint analysis of residential location, work location and commuting mode choices in Hanoi, Vietnam. Journal of Transport Geography, 54, 181-193. doi:10.1016/j.jtrangeo.2016.06.003

Van der Waerden, P., Borgers, A., \& Timmermans, H. (2003). Key events and critical incidents influencing transport mode choice switching behavior: an exploratory study. In Proceedings 82nd Annual Meeting of the Transportation Research Board.

van Dijk, J., Krygsman, S., \& de Jong, T. (2015). Toward spatial justice: The spatial equity effects of a toll road in Cape Town, South Africa. Journal of Transport and Land Use, 8(3), 95-114. doi:10.5198/jtlu.2015.555 
van Wee, B. (2009). Self-selection: a key to a better understanding of location choices, travel behaviour and transport externalities? Transport Reviews, 29(3), 279-292. doi:10.1080/01441640902752961

van Wee, B. (2012). How suitable is CBA for the ex-ante evaluation of transport projects and policies? A discussion from the perspective of ethics. Transport Policy, 19(1), 1-7. doi:10.1016/j.tranpol.2011.07.001

van Wee, B., Hagoort, M., \& Annema, J. A. (2001). Accessibility measures with competition. Journal of Transport Geography, 9(3), 199-208. doi:10.1016/S0966-6923(01)00010-2

Vega, A., \& Reynolds-Feighan, A. (2009). A methodological framework for the study of residential location and travel-to-work mode choice under central and suburban employment destination patterns. Transportation Research Part A: Policy and Practice, 43(4), 401-419. doi:10.1016/j.tra.2008.11.011

Verhetsel, A., \& Vanelslander, T. (2010). What location policy can bring to sustainable commuting: an empirical study in Brussels and Flanders, Belgium. Journal of Transport Geography, 18(6), 691-701. doi:10.1016/j.jtrangeo.2009.11.003

Vrtic, M., Schuessler, N., Erath, A., \& Axhausen, K. W. (2010). The impacts of road pricing on route and mode choice behaviour. Journal of Choice Modelling, 3(1), 109-126. doi:10.1016/S1755-5345(13)70031-9

Wachs, M. (1967). Relationships between drivers' attitudes toward alternate routes and driver and route characteristics. Highway Research Record(197), 70-87. Retrieved from https://trid.trb.org/view/93101

Walker, J. L. (2001). Extended discrete choice models: integrated framework, flexible error structures, and latent variables. (Doctoral thesis), Massachusetts Institute of Technology, Retrieved from https://dspace.mit.edu/handle/1721.1/32704

Walker, J. L., \& Li, J. (2007). Latent lifestyle preferences and household location decisions. Journal of Geographical Systems, 9(1), 77-101. doi:10.1007/s10109-006-0030-0

Wang, C.-H., \& Chen, N. (2015). A GIS-based spatial statistical approach to modeling job accessibility by transportation mode: case study of Columbus, Ohio. Journal of Transport Geography, 45, 1-11. doi:10.1016/j.jtrangeo.2015.03.015

Wang, J. Y. T., \& Ehrgott, M. (2013). Modelling route choice behaviour in a tolled road network with a time surplus maximisation bi-objective user equilibrium model. Transportation Research Part B: Methodological, 57, 342-360. doi:10.1016/j.trb.2013.05.011

Wang, Z., Han, Q., \& de Vries, B. (2018). Land Use/Land Cover and Accessibility: Implications of the Correlations for Land Use and Transport Planning. Applied Spatial Analysis and Policy, 1-18. doi:10.1007/s12061-018-9278-2

Wee, B., \& Geurs, K. (2011). Discussing equity and social exclusion in accessibility evaluations. European journal of transport and infrastructure research, 11(4). doi:10.18757/ejtir.2011.11.4.2940 
Wegener, M., \& Fürst, F. (2004). Land-use transport interaction: state of the art (Berichte aus dem Institut für Raumplanung 46). Retrieved from Institut für Raumplanung, Fakultät Raumplanung, Universität Dortmund: https://ssrn.com/abstract $=1434678$

WJP-MDM. (2013). Konsep awal pengembangan Metropolitan Bandung Raya (in Indonesian) [The initial concept of the Bandung Metropolitan development. Retrieved from West Java Province Metropolitan Development Management: http://metropolitan.jabarprov.go.id/ sources/download/paper/6f79c-06-konsep-awal-pengembangan-metropolitan-bandungraya_juni-2013_a22.pdf

Wootton, H., Ness, M., \& Burton, R. (1981). Improved direction signs and the benefits for road users. Traffic Engineering \& Control, 22(5). Retrieved from https://trid.trb.org/view/173643

Wuestefeld, N. H., \& Regan III, E. (1981). Impact of rate increases on toll facilities. Traffic Quarterly, 35(4). Retrieved from https://trid.trb.org/view/179699

Xiong, C., Zhu, Z., He, X., Chen, X., Zhu, S., Mahapatra, S., . . Zhang, L. (2015). Developing a 24-hour large-scale microscopic traffic simulation model for the before-and-after study of a new tolled freeway in the Washington, DC-Baltimore Region. Journal of Transportation Engineering, 141(6), 05015001. doi:10.1061/(ASCE)TE.19435436.0000767

Yáñez, M. F., Raveau, S., \& Ortúzar, J. d. D. (2010). Inclusion of latent variables in mixed logit models: modelling and forecasting. Transportation Research Part A: Policy and Practice, 44(9), 744-753. doi:10.1016/j.tra.2010.07.007 


\section{Appendix: Revealed preference questionnaire}

\section{EX-POST SURVEY}

Effects of the Cipularang Toll Road on Residential Location Choice, Travel Behaviour, and Accessibility

This survey is part of an international academic project conducted by Center for Transport Studies, University of Twente, the Netherlands. This survey is an ex-post survey on Cipularang Toll Road to quantify the extent of accessibility given the impact of the Cipularang toll road on residential location choice and travel behaviour changes.

All answers are confidential and you are not obligated to participate or answer any or all questions once you agree to participate. The results of this survey will not be shared with any external parties and will be only used for academic research.

Thank you for taking the time to participate in our survey.

B1. Housing location

$\begin{array}{ll}\text { a } & \text { Province } \\ \text { b } & \text { Regency / municipality } \\ \text { c } & \text { District } \\ \text { d } & \text { Sub }- \text { district } \\ \text { e } & \text { Coordinates }\end{array}$

\begin{tabular}{|l|}
\hline DROP-DOWN list \\
\hline DROP-DOWN list \\
\hline DROP-DOWN list \\
\hline DROP-DOWN list \\
\hline Capture GPS \\
\hline
\end{tabular}

\section{A. RECRUITMENT - CHECK QUOTAS}

A2. What is your age?

RESPONDENT MUST BE AGED 18+, IF UNDER 18 PLEASE stop

A3. What is your current work status?

SHOW SCREEN - STOP if 6/7/8/9/10 is chosen

1: Own account worker

2: Employer assisted by temporary workers/ unpaid worker 
3: Employer assisted by permanent workers

4: Employee

5: Freelancer

6: Unpaid workers

7: Unemployed due to the academic purpose

8: Retired

9: Unemployed and currently seeking for jobs

10: Unemployed and not seeking for jobs

A4a. How often do you travel between cities or provinces?

SHOW SCREEN - STOP if 7 is chosen

1: 4 of more times per week

2: 1 - 3 times per week

3: 1 - 3 times per month

4: 6 - 11 times per year

5: 1 - 5 times per year

6: Less than 1 time per year

7: Never travel between cities or provinces

A4b. How often do you travel using the toll road?

SHOW SCREEN - CHECK AGAINST USER FREQUENCY ON QUOTA SHEET

1: 4 of more times per week

2: 1 - 3 times per week

3: 1 - 3 times per month

4: 6 - 11 times per year

5: 1 - 5 times per year

6: Less than 1 time per year

A1. Did you relocate to this address after 2005?

1: Yes

2: No

\section{B. HOUSEHOLD INFORMATION}

B2. Record gender

1: Male

2: Female

B3. Current marital status

1: Single, that is never married

2: Married

3: Divorced

4: Widowed

5: Do not know

6: Prefer not to answer

7: Other, specify

B4 Number of household members in the house (including yourself)

Please confirm by asking whether anyone name was missed out. As an example: newborn babies, and members of household who have been away for less than 6 months.

If there is a household member who is leaving for less than 6 months but intended to move or would leaving home for 6 months and more is not counted as a household member. 
B5. Number of dependent children in the house

For question B6A - B6H, Please fill this table with employment information of each household member who is above 18

\begin{tabular}{|l|l|l|l|l|l|l|l|l|}
\hline No. & $\begin{array}{l}\text { Name of } \\
\text { Household } \\
\text { members }\end{array}$ & Age & $\begin{array}{l}\text { Work } \\
\text { status }\end{array}$ & $\begin{array}{l}\text { Side } \\
\text { job } \\
\text { (Y/N) }\end{array}$ & $\begin{array}{l}\text { Work } \\
\text { days/week }\end{array}$ & $\begin{array}{l}\text { Work } \\
\text { hours/day }\end{array}$ & $\begin{array}{l}\text { Range } \\
\text { of } \\
\text { income }\end{array}$ & $\begin{array}{l}\text { Expense on } \\
\text { Transportation } \\
\text { per month }\end{array}$ \\
\hline & B6A & B6H & B6C & B6D & B6E & B6F & B6G & B6H \\
\hline 1. & The respondent & A2 & A3 & & & & & \\
\hline 2. & & & & & & & & \\
\hline 3. & Etc. & & & & & & & \\
\hline
\end{tabular}

B6C. Work status

1: Own account worker

2: Employer assisted by temporary workers/ unpaid worker

3: Employer assisted by permanent workers

4: Employee

5: Freelancer

6: Unpaid workers

7: Unemployed due to the academic purpose

8: Retired

9: Unemployed and currently seeking for jobs

10: Unemployed and not seeking for jobs

SCRIPTING REMARK:

B6D - B6H will not be asked if B6C $=6 / 7 / 8 / 9 / 10$

B6F. Work hours/week

1: $<5$ hours per day

2: $5-8$ hours per day

3: $9-12$ hours per day

4: >12 hours per day

5: Do not know

B6G. Income per month

1: Under 2,500,000

2: $2,500,000-5,000,000$

3: $5,000,000-7,500,000$

4: $7,500,000-10,000,000$

5: Over $10,000,000$

6: Do not know

B6H. Expense on transportation per month.

Transportation expense includes fuel cost, parking cost, toll road, public transport cost and/or tip. Excluding: vehicle installment and maintenance

1: < Rp250.000

2: $\quad$ Rp250.000 - Rp750.000

3: Rp750.001 - Rp1.250.000

4: Rp1.250.001 - Rp1.750.000

5: $\quad \operatorname{Rp} 1.750 .000$ 
6: Do not know

\section{EMPLOYMENT}

$\mathrm{C} 1$. Where is your main job's location? If you do not have a fixed workplace, then job location that you visited most often.

a Province

b Regency / municipality

c District

\begin{tabular}{|l|}
\hline DROP-DOWN LIST: \\
Jakarta \\
botabek \\
Jawa barat \\
\hline DROP-DOWN LIST \\
\hline OE
\end{tabular}

C3. What is your main mode to go to your workplace?

1: Private motorcycle

2: Office motorcycle

3: Motortaxi

4: Private car

5: Office car

6: Public transport with fixed routes

7: Public transport with no fixed routes

8: Passenger vehicles (to be picked-up)

9: Train

10: Others, specify

C4. Transportation cost in regular days

Rp.

C5. How long the trip from home to the location of work in average.

MINUTES

D. VEHICLE OWNERSHIP

D1. Do you hold a driving license valid in Indonesia, either to drive a car or to drive a motorcycle, or truck?

1: SIM A (Mobil)

2: SIM B1

3: SIM B2

4: SIM C (Sepeda Motor)

5: None of these

D2. How many available motorized and non motorized vehicles are there in your household?

1: Private Car

2: Office Car

3: Private Motorcycles

4: Office Motorcycles

5: Bicycles (please exclude bicycle for below 10 years old)

\section{E. CIPULARANG TOLL ROAD EXPERIENCE}

E1. When was your recent trip using Cipularang toll road?

1: Yesterday

2: Still in this week

3: Last week 
4: Last month

5: Within last three months

6: Within last six months

7: Within 12 months (a year)

8: Last year

9: More than a year ago

10: Do not remember --> GO TO SECTION F

E2. Choose one from the list below which suits the characteristic of that recent trip.

1: Trip to workplace, self-paid toll fee

2: Trip to workplace, toll fee paid by employer / another party

3: Trip to workplace, toll fee paid by myself and employer / another party

4: Part of work trip, self-paid toll fee

5: Part of work trip, toll fee paid by employer / another party

6: Part of work trip, toll fee paid by myself and employer / another party

7: Non-work trip

8: Do not remember

E3. Your origin and destination trip

\begin{tabular}{l|l|l|}
\cline { 2 - 3 } Location & Origin & Destination \\
\cline { 2 - 3 } Entry / Exit toll gate & $\begin{array}{l}\text { Drop-down list: (1) Home, (2) } \\
\text { Workplace, (3) Other, }\end{array}$ & $\begin{array}{l}\text { Drop-down list: (1) Home, (2) } \\
\text { Workplace, (3) Other }\end{array}$ \\
\cline { 2 - 3 } & $\begin{array}{l}\text { show DROP-down list if 'other' is } \\
\text { chosen }\end{array}$ & $\begin{array}{l}\text { show drop-down list if 'other' is } \\
\text { chosen }\end{array}$ \\
\hline
\end{tabular}

E4. Which transport mode did you use?

1: Private car (owned by the respondent / relatives / friends / office / rent /others)

2: Passenger car (taxi, uber, etc)

3: Shuttle car

4: Public bus

E5. Total travel cost from origin to the destination from your recent trip via Cipularang toll road

Main mode

Connecting mode(s)

Total

$\square$ Do not know
Rp. $\square \square \square \square \square$ (longest trip)

Rp.

Rp.

E6. Travel time from your origin place to your destination in this trip using Cipularang toll road. MINUTES

E10a. Suppose you cannot use your current mode on this trip, which mode you will use to reach your destination?

1: Private car (owned by the respondent / relatives / friends / office / rent /others)

2: Passenger car (taxi, uber, etc)

3: Shuttle car

4: Public bus

E10b. How much is the estimated cost you should spend if using the above alternative vehicles?

Rp. 
E9. Why did you use this mode?

\begin{tabular}{lccccccc} 
& $\begin{array}{c}\text { Strongly } \\
\text { disagree }\end{array}$ & Disagree & Neutral & Agree & $\begin{array}{c}\text { Strongly } \\
\text { agree }\end{array}$ & $\begin{array}{c}\text { Do } \\
\text { not } \\
\text { know }\end{array}$ & $\begin{array}{c}\text { Does } \\
\text { not } \\
\text { apply }\end{array}$ \\
\hline $\begin{array}{l}\text { I do not have to } \\
\text { make several } \\
\text { transfers }\end{array}$ & $\square$ & $\square$ & $\square$ & $\square$ & $\square$ & $\square$ & $\square$ \\
\hline $\begin{array}{l}\text { My mode is safer } \\
\text { than the alternative } \\
\text { mode }\end{array}$ & $\square$ & $\square$ & $\square$ & $\square$ & $\square$ & $\square$ & $\square$ \\
\hline $\begin{array}{l}\text { My mode is more } \\
\text { comfortable than } \\
\text { the alternative } \\
\text { mode }\end{array}$ & $\square$ & $\square$ & $\square$ & $\square$ & $\square$ & $\square$ & $\square$ \\
\hline $\begin{array}{l}\text { I do not have to } \\
\text { wait long }\end{array}$ & $\square$ & $\square$ & $\square$ & $\square$ & $\square$ & $\square$ & $\square$ \\
\hline
\end{tabular}

E11 Could you reach your destination without using the Cipularang toll road?

1: Yes

2: No $\rightarrow$ GO TO SECTION G

E12. Why did you use the Cipularang toll road to reach your destination?

\begin{tabular}{llllllll} 
& $\begin{array}{c}\text { Strongly } \\
\text { disagree }\end{array}$ & Disagree & Neutral & Agree & $\begin{array}{c}\text { Strongly } \\
\text { agree }\end{array}$ & $\begin{array}{c}\text { Do } \\
\text { not } \\
\text { know }\end{array}$ & $\begin{array}{c}\text { Does } \\
\text { not } \\
\text { apply }\end{array}$ \\
\hline $\begin{array}{l}\text { There is no/low } \\
\text { congestion on the } \\
\text { toll road }\end{array}$ & $\square$ & $\square$ & $\square$ & $\square$ & $\square$ & $\square$ & $\square$ \\
\hline $\begin{array}{l}\text { Driving on toll } \\
\text { roads is safer than } \\
\text { on non-toll roads }\end{array}$ & $\square$ & $\square$ & $\square$ & $\square$ & $\square$ & $\square$ & $\square$ \\
\hline $\begin{array}{l}\text { Traffic signs on } \\
\text { toll roads are } \\
\text { complete and very } \\
\text { clear }\end{array}$ & $\square$ & $\square$ & $\square$ & $\square$ & $\square$ & $\square$ & $\square$ \\
\hline $\begin{array}{l}\text { Toll road has } \\
\text { better road surface } \\
\text { condition }\end{array}$ & $\square$ & $\square$ & $\square$ & $\square$ & $\square$ & $\square$ & $\square$ \\
\hline $\begin{array}{l}\text { Easy to reach toll } \\
\text { road gates from } \\
\text { my location }\end{array}$ & $\square$
\end{tabular}




\section{G. HOUSING SITUATION}

G1. How long have you been living in your current house?

\begin{tabular}{c|c}
$\square \square$ & year(s) \\
$\square \square$ & month(s)
\end{tabular}

G2 Which of these best describes your household tenure?

1: Owned $\rightarrow$ GO TO G4

2: Live for free $\rightarrow$ GO TO G4

3: Renting $\rightarrow$ GO TO G3

4: $\quad$ Provided by the employer $\rightarrow$ GO TO G4

5: Other, specify $\rightarrow$ GO TO G4

IF $\mathrm{G} 2=3$

G3. How much do you pay every month for rent?

Rp.

G4. What type of house do you have?

1: Detached house

2: Semi Detached house

3: Row house

4: Apartment/flat

5: Home unit with shared used of kitchen or toilet

6: Other, specify

G5. From very dissatisfied to very satisfied, please rate the importance of these following factors for you to choose housing?

$\begin{array}{llllllll} & \begin{array}{c}\text { Very } \\ \text { dissatis- } \\ \text { fied }\end{array} & \begin{array}{c}\text { Dissatis- } \\ \text { fied }\end{array} & \text { Neutral } & \text { Satisfied } & \begin{array}{c}\text { Very } \\ \text { satisfied }\end{array} & \begin{array}{c}\text { Do } \\ \text { not } \\ \text { know }\end{array} & \begin{array}{c}\text { Does } \\ \text { not }\end{array} \\ \text { apply }\end{array}$




\begin{tabular}{|c|c|c|c|c|c|c|c|}
\hline & $\begin{array}{l}\text { Very } \\
\text { dissatis- } \\
\text { fied }\end{array}$ & $\begin{array}{l}\text { Dissatis- } \\
\quad \text { fied }\end{array}$ & Neutral & Satisfied & $\begin{array}{c}\text { Very } \\
\text { satisfied }\end{array}$ & $\begin{array}{c}\text { Do } \\
\text { not } \\
\text { know }\end{array}$ & $\begin{array}{c}\text { Does } \\
\text { not } \\
\text { apply }\end{array}$ \\
\hline $\begin{array}{l}\text { Size of your housing } \\
\text { (including garden and } \\
\text { garage) }\end{array}$ & $\square$ & $\square$ & $\square$ & $\square$ & $\square$ & $\square$ & $\square$ \\
\hline $\begin{array}{l}\text { Building health and } \\
\text { safety standard (e.g safe } \\
\text { floods, mudslides, fire, } \\
\text { gas and electrical risk; } \\
\text { mold and pests) }\end{array}$ & $\square$ & $\square$ & $\square$ & $\square$ & $\square$ & $\square$ & $\square$ \\
\hline Number of bedrooms & $\square$ & $\square$ & $\square$ & $\square$ & $\square$ & $\square$ & $\square$ \\
\hline $\begin{array}{l}\text { Little exposure to traffic } \\
\text { emissions (noise and/or } \\
\text { pollution) }\end{array}$ & $\square$ & $\square$ & $\square$ & $\square$ & $\square$ & $\square$ & $\square$ \\
\hline $\begin{array}{l}\text { Level of safety in your } \\
\text { neighbourhood }\end{array}$ & $\square$ & $\square$ & $\square$ & $\square$ & $\square$ & $\square$ & $\square$ \\
\hline $\begin{array}{l}\text { General appeal } \\
\text { (aesthetics) of your } \\
\text { neighbourhood }\end{array}$ & $\square$ & $\square$ & $\square$ & $\square$ & $\square$ & $\square$ & $\square$ \\
\hline
\end{tabular}

\section{H RESIDENTIAL HISTORY (MOVER GROUP, A1=2)}

H1. How many times have you moved in the last 12 years (after 2005)?

1: 1

2: 2

3: 3

4: 4 or more

H2. How long did you live at your previous address?

\section{NUMBER OF MONTHS $\square \square$ \\ NUMBER OF YEARS}

H3. Location of your previous housing

$\begin{array}{ll}\text { a } & \text { Province } \\ \text { b } & \text { Regency / municipality } \\ \text { c } & \text { District } \\ \text { d } & \text { Sub-district }\end{array}$

\begin{tabular}{|l|}
\hline Open questions $(\mathrm{OE})$ \\
\hline OE \\
\hline OE \\
\hline OE \\
\hline
\end{tabular}

H4. Which of these best describes your previous household tenure?

1: Owned $\rightarrow$ GO TO H6

2: Live for free $\rightarrow$ GO TO H6

3: Renting $\rightarrow$ GO TO H5

4: $\quad$ Provided by the employer $\rightarrow$ GO TO H6

5: Other, specify $\rightarrow$ GO TO H6

IF $\mathrm{H} 4=3$

H5. How much did you pay every month for rent?

Rp.

H6 What type of house did you have?

1: Detached house

2: Semi Detached house 
3: Row house

4: Apartment/flat

5: Home unit with shared used of kitchen or toilet

6: Other, specify

H7. What was your reason to move to your current home?

ask open question first; spontaneous answer will be h7a (main reason), then show screen

$H 7 b$

(Other Reasons)

MULTIPLE CODES

To be closer to workplace

To be closer to shops / daily groceries

To be closer to child's school

To be closer to major streets

To be closer to public transport stop (bus stop / bus station)

Accessible by bus

Affordable rent/housing price

Lower living cost

Life events (e.g.: childbirth, marriage, retirement, divorced)

Following relatives (e.g. parents / partner)

Bigger house / needed more space

Safer and more comfortable neighborhood

Inheritance of parents/siblings

To be closer to family/friends

Relocation due to disaster (flood / landslide / earthquake / eviction / fire)

Job relocation

Others, specify

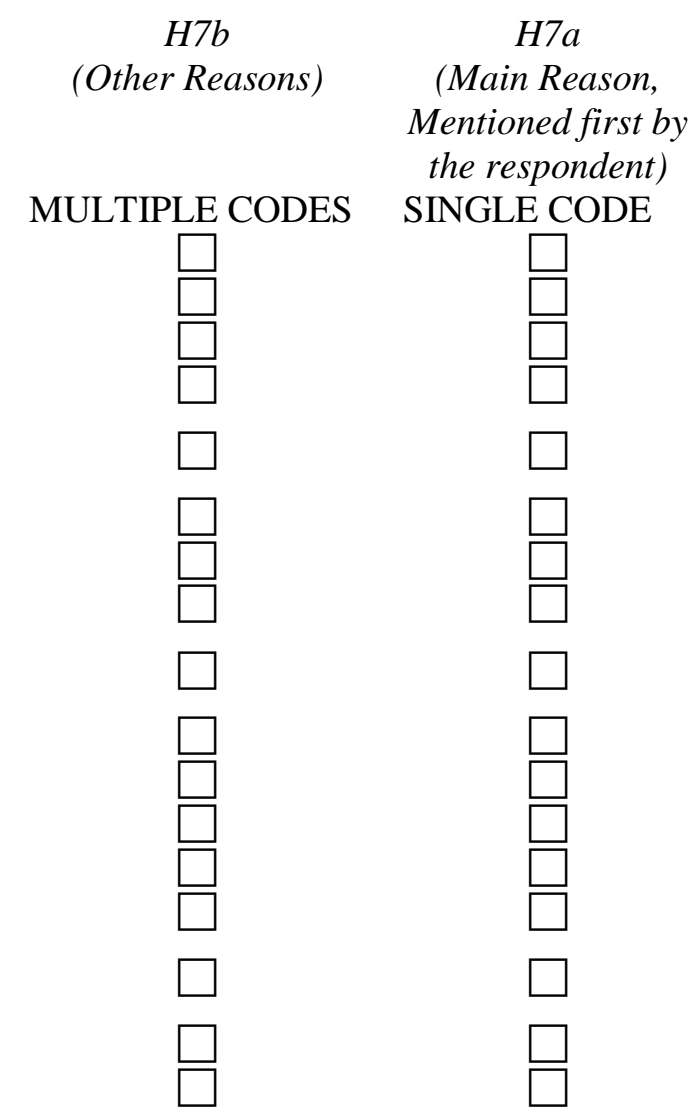

H8. Coming back to the list of aspects discussed before, how did those aspects change concerning your last move

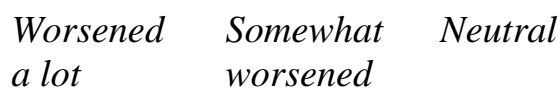

Somewhat Improved Does improved a lot not

Proximity to work (for myself and/or other household members)

\begin{tabular}{lllllll}
\hline $\begin{array}{l}\text { Proximity to future } \\
\text { employment } \\
\text { opportunities (for myself }\end{array}$ & $\square$ & $\square$ & $\square$ & $\square$ & $\square$ & $\square$ \\
and/or other household \\
members)
\end{tabular}




\begin{tabular}{|c|c|c|c|c|c|c|}
\hline & $\begin{array}{l}\text { Worsened } \\
\text { a lot }\end{array}$ & $\begin{array}{l}\text { Somewhat } \\
\text { worsened }\end{array}$ & Neutral & $\begin{array}{l}\text { Somewhat } \\
\text { improved }\end{array}$ & $\begin{array}{l}\text { Improved } \\
\text { a lot }\end{array}$ & $\begin{array}{l}\text { Does } \\
\text { not } \\
\text { apply }\end{array}$ \\
\hline $\begin{array}{l}\text { Proximity to school } \\
\text { and/or childcare }\end{array}$ & $\square$ & $\square$ & $\square$ & $\square$ & $\square$ & $\square$ \\
\hline $\begin{array}{l}\text { Proximity to public } \\
\text { facilities (clinic / } \\
\text { hospital, recreation area, } \\
\text { mosque / church) }\end{array}$ & $\square$ & $\square$ & $\square$ & $\square$ & $\square$ & $\square$ \\
\hline $\begin{array}{l}\text { Familiarity (close to } \\
\text { friends / family) }\end{array}$ & $\square$ & $\square$ & $\square$ & $\square$ & $\square$ & $\square$ \\
\hline $\begin{array}{l}\text { Affordability of your } \\
\text { home }\end{array}$ & $\square$ & $\square$ & $\square$ & $\square$ & $\square$ & $\square$ \\
\hline $\begin{array}{l}\text { Size of your housing } \\
\text { (including garden and } \\
\text { garage) }\end{array}$ & $\square$ & $\square$ & $\square$ & $\square$ & $\square$ & $\square$ \\
\hline $\begin{array}{l}\text { Building health and } \\
\text { safety standard (e.g. safe } \\
\text { floods, mudslides, fire, } \\
\text { gas and electrical risk; } \\
\text { mold and pests) }\end{array}$ & $\square$ & $\square$ & $\square$ & $\square$ & $\square$ & $\square$ \\
\hline Number of bedrooms & $\square$ & $\square$ & $\square$ & $\square$ & $\square$ & $\square$ \\
\hline $\begin{array}{l}\text { Little exposure to traffic } \\
\text { emissions (noise and/or } \\
\text { pollution) }\end{array}$ & $\square$ & $\square$ & $\square$ & $\square$ & $\square$ & $\square$ \\
\hline $\begin{array}{l}\text { Level of safety in your } \\
\text { neighbourhood }\end{array}$ & $\square$ & $\square$ & $\square$ & $\square$ & $\square$ & $\square$ \\
\hline $\begin{array}{lr}\text { General } & \text { appeal } \\
\text { (aesthetics) of } & \text { your } \\
\text { neighbourhood } & \end{array}$ & $\square$ & $\square$ & $\square$ & $\square$ & $\square$ & $\square$ \\
\hline
\end{tabular}

I TRAVEL DATA HISTORY (MOVER GROUP \& CIPULARANG TOLL ROAD FREQUENT USER, $\mathrm{A} 1=2 \& \mathrm{~A} 4 \mathrm{~B}=1-5$ )

I1. You mentioned that you had been moved your residential location, is your workplace located in the same place when you were living in the previous housing?

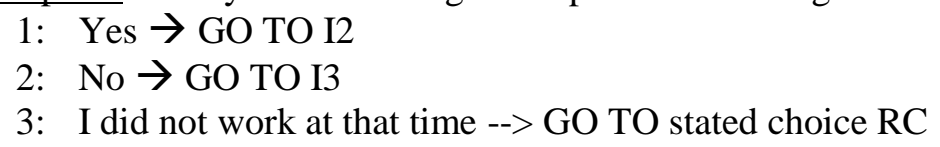

I2. Where was your main job's location?

$\begin{array}{ll}\text { a } & \text { Province } \\ \text { b } & \text { Regency / municipality } \\ \text { c } & \text { District }\end{array}$

\begin{tabular}{|l|}
\hline $\mathrm{OE}$ \\
\hline $\mathrm{OE}$ \\
\hline $\mathrm{OE}$ \\
\hline
\end{tabular}

I3 How long the trip was from home to the location of work in average?

\section{MINUTES}

I4. How many available motorized and non motorized vehicles were there in your household?
a. Private Car $\square$
b. Office Car $\square$
c. Private Motorcycles
d. Office Motorcycles $\square$ 
e. Bicycles (please exclude bicycle for below ten years old)

I5. Did you use the same main mode to go to work when you lived in your previous housing?

1: $\quad$ Yes $\rightarrow$ GO TO I7

2: No

I6. What was your main mode to go to your workplace?

1: Private motorcycle

2: Office motorcycle

3: Private car

4: Office car

5: Public transport with fixed routes

6: Public transport with no fixed routes

7: Passenger vehicles (to be picked-up)

8: Train

9: Others, specify

I7. Transportation cost for each day in regular days back then

a. Main mode

b. Connecting mode(s)

c. Total

Rp.

Rp.

$\square$ Do not know

Rp.

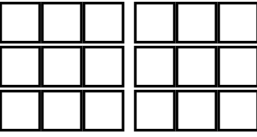

GO TO stated choice $R C$

J. RESIDENTIAL HISTORY (STAYER, A6 = 1)

J1. How did the following aspects change concerning your neighborhood condition before 2005 ?

Worsened Somewhat Neutral / Somewhat Improved Does alot worsened none improved alot not

Proximity to work (for myself and/or other household members)

\begin{tabular}{|c|c|c|c|c|c|}
\hline $\begin{array}{l}\text { Proximity to future } \\
\text { employment } \\
\text { opportunities (for myself } \square \\
\text { and/or other household } \\
\text { members) }\end{array}$ & $\square$ & $\square$ & $\square$ & $\square$ & $\square$ \\
\hline $\begin{array}{l}\text { Well-connected by public } \square \\
\text { transports }\end{array}$ & $\square$ & $\square$ & $\square$ & $\square$ & $\square$ \\
\hline $\begin{array}{l}\text { Proximity to shops for } \square \\
\text { daily groceries }\end{array}$ & $\square$ & $\square$ & $\square$ & $\square$ & $\square$ \\
\hline $\begin{array}{l}\text { Proximity to school } \square \\
\text { and/or childcare }\end{array}$ & $\square$ & $\square$ & $\square$ & $\square$ & $\square$ \\
\hline $\begin{array}{l}\text { Proximity to public } \\
\text { facilities (clinic / hospital, } \\
\text { recreation area, mosque / } \\
\text { church) }\end{array}$ & $\square$ & $\square$ & $\square$ & $\square$ & $\square$ \\
\hline $\begin{array}{l}\text { Familiarity (close to } \\
\text { friends / family) }\end{array}$ & $\square$ & $\square$ & $\square$ & $\square$ & $\square$ \\
\hline $\begin{array}{lll}\begin{array}{l}\text { Affordability } \\
\text { home }\end{array} & \text { of your } \square \\
\end{array}$ & $\square$ & $\square$ & $\square$ & $\square$ & $\square$ \\
\hline
\end{tabular}




\begin{tabular}{|c|c|c|c|c|c|c|}
\hline & $\begin{array}{l}\text { Worsened } \\
\text { a lot }\end{array}$ & $\begin{array}{l}\text { Somewhat } \\
\text { worsened }\end{array}$ & $\begin{array}{l}\text { Neutral } \\
\text { none }\end{array}$ & $\begin{array}{l}\text { / Somewhat } \\
\text { improved }\end{array}$ & $\begin{array}{l}\text { Improved } \\
\text { a lot }\end{array}$ & $\begin{array}{l}\text { Does } \\
\text { not } \\
\text { apply }\end{array}$ \\
\hline $\begin{array}{l}\text { Size of your housing } \\
\text { (including garden and } \\
\text { garage) }\end{array}$ & $\square$ & $\square$ & $\square$ & $\square$ & $\square$ & $\square$ \\
\hline $\begin{array}{l}\text { Building health and } \\
\text { safety standard (e.g safe } \\
\text { floods, mudslides, fire, } \\
\text { gas and electrical risk; } \\
\text { mould and pests) }\end{array}$ & $\square$ & $\square$ & $\square$ & $\square$ & $\square$ & $\square$ \\
\hline Number of bedrooms & $\square$ & $\square$ & $\square$ & $\square$ & $\square$ & $\square$ \\
\hline $\begin{array}{l}\text { Little exposure to traffic } \\
\text { emissions (noise and/or } \\
\text { pollution) }\end{array}$ & $\square$ & $\square$ & $\square$ & $\square$ & $\square$ & $\square$ \\
\hline $\begin{array}{l}\text { Level of safety in your } \\
\text { neighbourhood }\end{array}$ & $\square$ & $\square$ & $\square$ & $\square$ & $\square$ & $\square$ \\
\hline
\end{tabular}




\section{Summary}

Toll roads are built for various reasons. In many developing countries, such as Malaysia, Thailand and Indonesia, a toll is commonly implemented on major highways as a way to fund the construction. On the other hand, in some developed countries and metropolitan areas, such as London and Stockholm, tolls can be intended to influence users' travel behaviour and reduce congestion. Regardless of their objective, toll roads can have a variety of effects, both direct and indirect.

Direct effects of major new road construction relate to changes in travel time, travel distance and travel costs, which leads to changes in the users' behaviours. People may, for instance, change their routes or travel modes to explore the new capacity. Indirect effects occur when over time, they may change their housing locations as a result of the travel time reduction or travel cost increment, along with other determinants, such as, the dwelling and neighbourhood characteristics, socio-demographic characteristics, lifestyle or preferences. A change in the transport system will lead to changes in land-use and induce other road investments, which can be defined as an indirect effect of the transport infrastructure system. The direct and indirect impacts of new roads can be unevenly distributed both across a population and across an area. This thesis, therefore, focused on direct and indirect effects of a toll road construction and how these impacts are distributed across population groups and regions.

In Indonesia, in the period 2015 - 2018, almost $600 \mathrm{~km}$ of new toll roads were taken into operation, as the government pushed the construction of toll roads to improve regional connectivity. These toll roads have been developed following the paradigm of 'predict and provide' - that is, the construction of transport infrastructure to meet the demand without considering long run induced demand and supply effects. Ideally, transport policy should follow the decision-making cycle, in which needs or a rationale are identified first to define the objectives or the desired transport system. Then, an ex-ante evaluation (appraisal) is conducted to identify possible transport policies or projects. Subsequent steps (monitoring, ex-post 
evaluation and feedback) after the policy has been implemented are often neglected. Ex-post evaluations are essential to assess the achieved outcome and identify the indirect effects of road projects.

Furthermore, in practice, equity appraisals received little attention in transport infrastructure project evaluations in developing countries such as Indonesia. Current transport project appraisals are mostly based on economic appraisals (e.g. cost and benefit analysis) in which there is no particular concern with how the benefits are distributed among individuals or population groups.

Therefore, the main objective of the research compiled in this thesis:

To provide a comprehensive understanding of the direct and indirect impacts of toll roads in the Jakarta - Bandung region in Indonesia, and how these impacts differ between geographical regions and population groups.

The case study area, the Jakarta - Bandung region in Indonesia, was chosen as the focus of this study. The two metropolitan cities are connected with the Cipularang toll road, forming the largest urban population in Indonesia. This region takes up a significant position at the national scale. It occupies up less than $1 \%$ of the country's surface area, but $30 \%$ of the total length of all national toll roads is located here and $14 \%$ of the country's total population lives in it.

An analysis was conducted at the regional and individual level to investigate how the establishment of the Cipularang toll road has affected the transport system and how its benefits are distributed across various population segments and regions. The analysis of the regional impact (in Chapters 2 and 3) was carried out by GIS spatial analysis and modelling. The analysis of the effects for individuals (in Chapters 4 and 5) is based on a household survey among 1,600 respondents who live in the proximity of the Cipularang toll road. The survey generated stated and revealed preference data on residential location, route and mode choices.

Chapter 2 examines the impacts of the toll road on local road projects in the Jakarta-Bandung region. The literature on induced supply investments has focused on major road investments in developed countries. There is a need for a better understanding of how national road infrastructure projects induce local road projects that affect the transport and accessibility impacts of the investments. It is particularly relevant in developing countries with decentralised government systems such as Indonesia, where the different levels of governance share the responsibility for the transport networks. Indonesia's central government authorises investments in national roads, e.g. toll roads, while the lower-tier levels of government control local road projects. Local roads connect districts and communities, carry low traffic volumes and have the lowest speed limit. Coordination, however, has become a major concern to increase the benefits of transport investment across regions.

As the author is aware, no study has investigated the relationship between national road investments and the decision-making for local road projects. To investigate induced supply of local roads, four models were developed: (1) a decision-making (base) model, (2) a direct effects model, (3) an indirect effects model, and (4) a composite model, which combines the base, direct and indirect effect models.

The modelling results show that existing and planned toll roads induce the development of local road projects both directly and indirectly. Local road projects tend to be developed in anticipation of the opening of the toll road, and advocated by local governments to reduce travel time. Changes in residential area and population around the toll road also lead to local road 
construction. However, these variables were found to be less sensitive than other variables included in this study, such as distance to toll gate, the time gap (in years) between toll road construction and local road construction, and investment cost.

With regard to decision-making, local governments in Indonesia were seen to prioritise the construction of relatively long road segments that are already included in regional spatial plans. It was also found that local governments prefer to select relatively expensive projects, as bigger projects are perceived to have greater accessibility benefits as well as to be of greater political interest. These findings strengthen the argument that it is necessary to take into account not only induced-demand effects, but also induced-supply effects in the economic appraisals of road projects.

Chapter 3 provides evidence for how the accessibility impacts of the new toll road are actually distributed over the adjacent regions. This was obtained by calculating job accessibility and spatial equity in scenarios with and without toll road. An ex-post evaluation of the impact of a toll road on job accessibility and spatial equity in a developing country context, to the author's knowledge, has not been done before. A macroscopic traffic simulation model, the Traffic Analyst ArcGIS extension, was deployed to obtain valid estimates of travel time and generalised cost, taking into account congestion effects. Value of time estimates were used, based on stated choice experiments included in the survey conducted as part of this thesis (see also Chapters 4 and 5).

There are many ways to measure accessibility. Here, two accessibility indicators were used. A potential accessibility measure and the Shen index to include competition effects. The Shen index measures the proportion of the number of jobs within reach of a resident from an origin within a certain travel distance (potential supply) to the working population within reach of the same destination (potential demand). A log-logistic distance decay function produced the best fit with the travel data and applied to estimate the potential job and working population accessibility.

Equity effects were assessed by using the Palma ratio and the Gini coefficient as well as the spatial distribution of the accessibility changes, using a two-step cluster analysis. The Gini coefficient is estimated by using the trapezoidal Lorenz curve approximation, depicting the (ranked) cumulative share of accessibility per person against the cumulative share of the corresponding population by district across the Jakarta - Bandung region. The Palma ratio is the ratio between the average accessibility of the richest $10 \%$ districts and the poorest $40 \%$ districts. Accessibility measures and districts in the study area were then clustered by using a two-step cluster method in which the number of clusters was determined on the basis of the minimum value of the Bayesian information criterion.

The results show that the construction of the Cipularang toll road has reduced the average travel time in the Jakarta-Bandung area by $13 \%$. For specific districts located at the north and south ends of the toll road, the travel time is now up to 1.5 times shorter. The reduction of travel time also affects job accessibility. The employment and working population accessibility each have increased by $5 \%$ by the establishment of the toll road. However, the toll road also increases job competition slightly as more workers can now access jobs available in the job-poor area between Jakarta and Bandung, resulting in a small decrease in the number of accessible jobs per worker. Most affected areas have a relatively large working population compared to number of jobs and experienced residential land use growth. It was further found that the toll road has no impact on spatial inequity. This measurement, however, does not take mode choice into account. In Indonesia, low-income workers rely on motorcycles, which are not allowed on most 
toll roads. In practice, this does mean that higher income workers benefit stronger than lowerincome workers.

The subsequent chapters focus on the impacts of the toll road on individuals, assessed with the aid of a household survey. The survey conducted with computer-aided personal interview (CAPI) technology. Respondents were selected who experienced major land use changes, covering 35 villages (sub-districts). Ten sub-districts located between 6 and $12 \mathrm{~km}$ from the toll road were included in the sample as the control area. The respondents were sampled on the basis of stratified random sampling. Grouping was based on the proportion of gender and age groups in the population.

Chapter 4 provides empirical insights into residential location choice in response to the presence of the toll road. Few quantitative studies are available on the impact of road infrastructure on residential location choice in developing countries, but to the author's knowledge, no studies have addressed toll roads which adds complexity as explicit trade-offs between travel time savings and toll fee costs are introduced. This chapter presents a comprehensive ex-post evaluation of toll road construction in the context of developing countries, using a joint revealed and stated preference survey. It presents the application of a traditional mixed logit and a hybrid choice model to analyse the effect of satisfaction components in residential location choice linked to a toll road construction, using several distance segments to the toll gate.

This chapter contains an analysis of data from a stated-choice experiment on residential location choice, in which the respondents were provided with several choice cards. For each choice card, they had to choose between hypothetical house A, house B and their current home. Each option had a different value of attributes (rent/land tax, travel time to work, travel cost to work and distance to toll gate). The values of the attributes were pivoted from the respondents' current data, to provide a realistic context. To analyse the data, a hybrid-choice model was developed to model residential location choice, capturing the effects of observed variables, such as socioeconomics, travel characteristics, housing characteristics, as well as unobserved variables, which are satisfactions with current neighbourhood and housing.

The results show that people whose incomes are at least three times the minimum wage were found willing to pay higher land taxes to live closer than $5 \mathrm{~km}$ to the toll road to capture travel time benefits. On the other hand, individuals in other income segments preferred to live beyond $10 \mathrm{~km}$ from the toll gate where housing costs tend to be low. However, this led to dissatisfaction with neighbourhood aspects for respondents who lived beyond $10 \mathrm{~km}$ from the toll gate.

Furthermore, improving satisfaction with the current housing situation and neighbourhood to the model increased the probability that people will stay in their current home, with the exception of individuals whose incomes are lower than the minimum wage. Respondents were found to be satisfied with their neighbourhood if they were living close to the toll gate. However, people were less satisfied with the size and affordability of their housing if they were living closer to the toll gate, probably due to higher rents or land taxes. Furthermore, lowincome respondents were not satisfied with their current housing and neighbourhood, and preferred to relocate. This result is strengthened by the finding that the same dissatisfaction was also experienced by respondents who were living in poorer municipalities.

Chapter 5 explores the impact of the Cipularang toll road on route and mode choice and the interaction between route and mode choice and residential location choice. This study adds to the literature by examining travel behaviour impacts across various population segments in response to a toll road's presence using (1) a joint model of residential location decision and 
route and mode choices to identify self-selection, and (2) a hybrid choice model to capture attitudinal effects of the toll road and the travel mode. In Indonesia context, where numerous new toll roads are being operated in the past decade, no studies have investigated travel behaviour effects across population segments and the relation with residential location decision in greater detail. In general, this is important because the effects of toll implementation on users' behaviour vary depending on the trip characteristics or socio-economic backgrounds.

This was accomplished with data from a joint stated choice experiment for residential location choice and travel behaviour (route and mode choices). The respondents were asked to choose between four alternatives, which were a combination of route and mode choice: (1) travel via the toll road and use the same mode, (2) travel via the toll road and use a different mode, (3) use the same mode but not travel via the toll road, or (4) not travel via the toll road and use a different mode. Each choice card contained different values for travel costs and travel time, which was pivoted from the real values of the respondent's most recent trip via the toll road. Opt-out choices, such as "prefer a different mode" (e.g. motorcycle or train) and "prefer not to travel", were provided as well. These alternatives allow the respondents to select another alternative if they do not prefer any of the options provided in the choice set.

The model estimation results show that, in general, the respondents preferred options that made use of the toll road. However, low-income individuals would select opt-out choices, allowing them to travel using the cheapest travel mode (train or motorcycle), in contrast with upperincome respondents who prefer to use toll roads. The respondents also perceived travel cost and travel time negatively. Low-income car drivers were found to be the most sensitive toward an increased travel cost among car users. Other variables, such as age, gender, trip purpose and trip frequency, also were found to have a significant influence on route choice and mode choice.

Furthermore, route, mode and residential location choices were found to be associated through common parameters of distance to the toll gate, trip frequency, and income level. Respondents who live close to toll gates prefer to use the toll road are likely to stay in their current residence. Frequent users of the toll road would not choose the options without the toll road and tend to relocate. Low-income respondents also tend to relocate from their current housing. This implies dissatisfaction on their current situation, as also shown by their negative attitude toward the current mode, and would rather choose another situation. This association indicates the interaction between route and mode choices and residential location decisions.

As in conclusion (Chapter 6), this thesis provides empirical evidence that a toll road can have direct and indirect effects and that these effects can be distributed unevenly across geographic regions and individuals. This thesis also shows that the construction of a new toll road can have both positive and negative impacts, especially in a region with an imbalanced distribution of activities, an incompletely developed transport system and a high inequality of income.

Furthermore, this thesis contributes to the advancement of the scientific field of transport evaluation through a comprehensive analysis at the level of regions and individuals to assess toll road impacts. It combines analysis carried out by GIS spatial analysis and modelling with behavioural modelling on individuals using a large scale stated and preference survey data.

The findings of this study urge the incorporation of accessibility planning and equity concerns into the policy practice. Accessibility planning underlines the integration of land use and transport planning with the goal of enabling all individuals, regardless of their social class or ability, to participate in any activities in the area by using the current transport system. This thesis also emphasises the importance of the transport policy cycle, and that ex-post evaluations are essential to assess whether objectives are being accomplished as well as to identify indirect 
effects. Ex-post evaluations are necessary to either find support for the adopted rationale or the need to change transport policy.

There are many directions for future research. Amongst others, is important to improve the job accessibility analysis by collecting data across job sectors, including the informal sector, and educational backgrounds. In addition, it is important to look at the relocation of firms and their workers in the assessment of job accessibility and to explain industrial land use developments in response to major toll road construction. Further research should also study the impacts of the Cipularang toll road on leisure / non-work trips, given that this trip purpose is important among users of this toll road. 


\section{Samenvatting in het Nederlands}

Tolwegen worden voor uiteenlopende redenen aangelegd. In veel ontwikkelingslanden, zoals Maleisië, Thailand en Indonesië, wordt tol geheven op belangrijke snelwegen om de aanleg te financieren. In ontwikkelde landen en metropoolregio's, zoals Londen en Stockholm, heeft het heffen van tol veelal tot doel om reizigersgedrag te beïnvloeden en congestie te reduceren. Ongeacht het doel, het heffen van tol op wegen zorgt voor verschillende, directe en indirecte, effecten.

Onder directe effecten, als het gevolg van het aanleggen van nieuwe wegen, wordt de verandering in reistijd, -afstand en -kosten verstaan. Dit zorgt voor een veranderingen in verplaatsingsgedrag: reizigers passen hun route of modaliteit aan, wat vervolgens kan resulteren in indirecte effecten. Zo kunnen veranderingen in werk- of woonlocaties optreden. De aanleg van nieuwe wegen kunnen ook zorgen voor veranderingen in het landgebruik, zoals aanleg van nieuwe woongebieden, en andere investeringen in infrastructuur. De bijkomende kosten en de veranderingen in reistijd door het aanleggen van een tolweg kunnen ongelijk verdeeld zijn, zowel geografisch als tussen bevolkingsgroepen. Dit proefschrift concentreert zich op de directe en indirecte effecten van de aanleg van tolwegen in Indonesië, en de verdeling daarvan tussen bevolkingsgroepen en regio's.

In de periode tussen 2015 en 2018 is er in Indonesië bijna 600 kilometer aan nieuwe tolwegen in gebruik genomen. De overheid stimuleerde de aanleg van tolwegen om regionale verbindingen te verbeteren. Hierbij wordt traditionele paradigma 'predict and provide' gevolgd, ofwel de aanleg van infrastructuur om aan de vervoersvraag op de korte termijn te voldoen, zonder daarbij rekening te houden met de generatie van nieuwe vervoersvraag en infrastructuuraanbod op de langere termijn.

Transportbeleid is idealiter gebaseerd op een beleidscyclus. Hierbij wordt eerst de noodzaak en de doelstelling van het gewenste transportsysteem geïdentificeerd. Vervolgens wordt er een exante beleidsevaluatie uitgevoerd om mogelijke projecten of beleidsalternatieven op te stellen. Vervolgstappen (monitoring, ex-post beleidsevaluatie en terugkoppeling) nadat het beleid is uitgevoerd, worden in ontwikkelingslanden vaak overgeslagen. Een ex-post beleidsevaluatie is echter essentieel om de gewenste en ongewenste effecten van weginvesteringen in kaart te 
brengen. De lessen uit ex post evaluaties kunnen worden gebruikt om ex ante evaluaties te kunnen verbeteren. Dit proefschrift richt zich op ex post evaluatie van tolwegen.

Bij evaluaties van investeringen in weginfrastructuur is in ontwikkelingslanden veelal beperkt aandacht voor de effecten met betrekking tot de rechtvaardigheid van transportbeleid. De meeste evaluaties beperken zich tot de economische effecten (kosten-baten analyse). Hierbij is beperkt of geen expliciete aandacht voor de verdeling van kosten en baten over de individuen.

De doelstelling van dit proefschrift is als volgt:

Het schetsen van een compleet beeld van de directe en indirecte effecten van tolwegen in de regio Jakarta - Bandung in Indonesië, en de verdeling van deze effecten over verschillende regio's en bevolkingsgroepen.

Dit proefschrift behandelt een casestudy in de Jakarta - Bandung regio in Indonesië. De twee metropolen worden verbonden door de Cipularang tolweg. De regio heeft de grootste stedelijke bevolking van Indonesië. De regio is van essentieel belang voor Indonesië. Ondanks dat qua oppervlakte de regio minder dan $1 \%$ van het totale oppervlakte beslaat, is $30 \%$ van de totale lengte van alle tolwegen in Indonesië is hier gesitueerd en leeft $14 \%$ van de totale bevolking in deze regio.

Een analyse op zowel regionaal als individueel niveau is in dit proefschrift uitgevoerd om te onderzoeken hoe de ingebruikname van de Cipularang tolweg invloed heeft gehad op het transportsysteem, en hoe de effecten zijn verdeeld over de verschillende bevolkingsgroepen en regio's. Daarvoor is er gebruik gemaakt van op GIS gebaseerde ruimtelijke analyses en modellen (Hoofdstukken 2 en 3). Om de effecten op individueel niveau te bepalen, is een enquête uitgevoerd onder 1600 respondenten die in de nabijheid van de Cipularang tolweg wonen. De enquête bevatte onder meer keuze experimenten (Hoofdstukken 4 en 5).

Hoofdstuk 2 behandelt de invloed van tolwegen op lokale wegprojecten in de Jakarta Bandung regio. De literatuur op het gebied van geïnduceerde investeringen in wegen beperkt zich tot investeringen in westerse landen. Er is weinig bekend over hoe nationale infrastructuurprojecten lokale wegprojecten stimuleren, die daarmee de effecten op het gebied van transport en bereikbaarheid beïnvloeden. Dit is met name relevant in ontwikkelingslanden met een gedecentraliseerd overheidsstelsel, zoals Indonesië, waar verschillende bestuurslagen de verantwoordelijkheid voor het transportnetwerk delen. De centrale overheid geeft toestemming voor investeringen in nationale infrastructuurprojecten, bijvoorbeeld de aanleg van tolwegen, terwijl lagere bestuursniveaus vooral lokale projecten leiden. Lokale wegen verbinden districten en dorpen, en worden gekenmerkt door lage verkeersvolumes en lage snelheidslimieten. Coördinatie tussen projecten uit verschillende regio's wordt steeds belangrijker om de baten van transportinvesteringen te maximaliseren.

Voor zover de auteur weet is er geen studie die de relatie tussen investeringen in nationale wegprojecten en de besluitvorming voor lokale wegprojecten heeft bestudeerd. Om het geïnduceerde aanbod van lokale wegen te bestuderen, zijn er vier modellen ontwikkeld: (1) een besluitvorming (basis) model, (2) een directe effecten model, (3) een indirecte effecten model en (4) een samengesteld model dat het basis, directe en indirecte effecten model combineert.

De modelresultaten geven weer dat de bestaande en geplande tolwegen zowel direct als indirecte lokale wegprojecten induceren. Lokale projecten lijken te worden ontwikkeld ter anticipatie op de opening van de tolweg. Woningbouw en een toename van de bevolking in de nabijheid van tolwegen stimuleert ook de aanleg van nieuwe lokale wegen. Belangrijkere 
verklarende variabelen voor de aanleg van lokale wegen zijn echter de afstand tot de tolpoorten, het tijdsinterval (in jaren) tussen de aanleg van de tolweg en lokale wegaanleg, en de investeringskosten.

Besluitvormingsprocessen van lokale overheden in Indonesië spelen ook een rol. Het onderzoek wijst uit dat lokale overheden de aanleg van relatief lange verbindingen prioriteren die in de regionale ruimtelijke plannen zijn opgenomen. Lokale overheden lijken dure projecten te prefereren, aangezien deze projecten van groter politiek belang zijn en men denkt dat deze meer bereikbaarheidsbaten opleveren. De resultaten versterken het argument dat het noodzakelijk is om in ex ante evaluaties van wegprojecten niet alleen de effecten op de geïnduceerde vraag mee te nemen, maar ook de effecten met betrekking tot het geïnduceerde aanbod.

Hoofdstuk 3 beschrijft hoe de bereikbaarheidseffecten van de nieuwe tolweg zijn verdeeld over de aangrenzende regio's. De effecten zijn bepaald door de verschillen in de geografische bereikbaarheid van werkgelegenheid te vergelijken in scenario's met en zonder tolweg. Voor zover de auteur weet, is een vergelijkbare studie in de context van een ontwikkelingsland nog niet eerder uitgevoerd. Een macroscopisch verkeersmodel, de ArcGIS-extensie Traffic Analyst, is gebruikt om effecten op reistijden en de gegeneraliseerde kosten te bepalen, rekening houdende met congestie-effecten. Hierbij zijn reistijdwaarderingen gebruikt die zijn geschat op basis van de stated-choice experimenten opgenomen in de survey die voor dit proefschrift is uitgevoerd (zie ook hoofdstukken 4 en 5).

Er bestaan veel verschillende bereikbaarheidsmaten. In dit hoofdstuk zijn 2 bereikbaarheidsmaten gebruikt. Er is gebruik gemaakt de potentiële bereikbaarheid van banen en de zogenoemde Shen index De Shen index geeft de verhouding tussen het potentiele bereikbaarheid van banen (potentiële aanbod) en het aantal inwoners dat deze banen kan bereiken (potentiële vraag). De Shen index houdt hiermee - in tegenstelling tot de potentiële bereikbaarheidsindex - rekening met de concurrentie op banen. Een log-logistische afstandsvervalfunctie zorgde voor de beste fit met de data, en is toegepast in beide bereikbaarheidsmaten om de potentiële (vraag en aanbod) bereikbaarheid te bepalen.

De effecten met betrekking tot ruimtelijke ongelijkheid zijn bepaald door gebruik te maken van de Gini coëfficiënt en de Palma ratio. Daarnaast is er gekeken naar de ruimtelijke verdeling van de veranderingen in bereikbaarheid, middels een cluster analyse. De Gini coëfficiënt is bepaald door een benadering met de trapezoidal Lorenz curve. De curve beschrijft het cumulatieve aandeel van de bereikbaarheid per persoon ten opzichte van het cumulatieve aandeel van de inwoners van het corresponderende district in de Jakarta - Bandung regio. De Palma ratio is de ratio tussen het de gemiddelde bereikbaarheid van de rijkste $10 \%$ van de districten en de armste $40 \%$ van de districten. Bereikbaarheidsmaten en districten zijn vervolgens geclusterd door gebruik te maken van een twee-staps-clustermethode, waarin het aantal clusters is bepaald op basis van de minimumwaarde van het Bayesian Information Criterion.

De resultaten laten zien dat door de aanleg van de Cipularang tolweg de gemiddelde reistijd in de Jakarta - Bandung regio met $13 \%$ is afgenomen. Voor specifieke districten aan het noordelijk en zuidelijk eind van de tolweg is de reistijd tot 1.5 keer korter geworden. De afname in reistijd heeft ook effect op de bereikbaarheid van banen. De banen en beroepsbevolkingbereikbaarheid zijn beiden met 5\% toegenomen door de aanleg van de tolweg. Echter, de tolweg zorgt ook voor een lichte toename in de concurrentie op banen aangezien meer werkenden toegang hebben tot de beperktere hoeveelheid banen in de regio tussen Jakarta en Bandung, wat zorgt voor een kleine afname in het aantal bereikbare banen per werkende. De tolweg lijkt geen effect te hebben op ruimtelijke onrechtvaardigheid gemeten met de Gini index en de Palma 
ratio. In deze analyse is geen rekening gehouden met de beschikbaarheid van vervoermiddelen. In Indonesië zijn werkenden met lage inkomens veelal afhankelijk van een motorfiets om het werk te kunnen bereiken. Motorfietsen zijn echter niet toegestaan op tolwegen. Dit betekent in de praktijk dat werkenden die een auto bezitten, veelal hogere inkomens, meer van de tolweg profiteren.

De laatste twee hoofdstukken (hoofdstukken 4 en 5) bekijken de effecten van de tolweg op individueel niveau, en zijn bepaald middels een huishoudensenquête. De enquête is uitgevoerd door gebruik te maken van een computerondersteund persoonlijk interview (CAPI). Respondenten zijn geselecteerd gebaseerd op de veranderingen in landgebruik en omvat 35 dorpen (sub-districten). Tien sub-districten, in een straal van 6 tot $12 \mathrm{~km}$ van de tolweg, zijn meegenomen als controlegroep. De respondenten zijn geselecteerd op basis van stratified random sampling. De stratificatie is gebaseerd op het aandeel van geslacht en leeftijdsgroepen in de bevolking.

Hoofdstuk 4 geeft empirische inzichten in de woonlocatiekeuze als gevolg van de aanleg van Cipularang tolweg. Er zijn maar een paar kwantitatieve studies die de effecten van wegen op de woonlocatiekeuze in ontwikkelingslanden onderzocht hebben en, voor zover bekend, geen van deze studies heeft specifiek naar tolwegen gekeken. Een tolweg zorgt voor extra complexiteit aangezien er een expliciete wisselwerking tussen reistijdwinst en tol bestaat. Dit hoofdstuk presenteert een ex-post evaluatie van de tolweg in de context van een ontwikkelingsland, waarbij gebruik is gemaakt een gecombineerde revealed en stated preference experimenten. Dit hoofdstuk presenteert de toepassing van een traditioneel mixed logit en een hybride keuzemodel om de effecten van de aanleg van de tolweg met betrekking tot tevredenheid in woonlocatiekeuze te analyseren. Hierbij is er gebruik gemaakt van afstandssegmenten tot de verschillende tolpoorten.

In het keuze experiment zijn respondenten verschillende keuzekaarten voorgelegd. Respondenten moesten, per keuzekaart, kiezen tussen hypothetisch huis A, hypothetisch huis B en hun huidige woning. Elke optie kent verschillende waarden voor verschillende kenmerken van de woning en de locatie van de woning (huur / grondbelasting, reistijd tot werk, reiskosten tot werk en afstand tot tolpoort). De waarden van deze kenmerken zijn gebaseerd op de daadwerkelijke situatie (revealed preference) van de respondenten, om daarmee een realistische context te creëren. Er is een hybride keuzemodel ontwikkeld om de data te analyseren. Dit keuzemodel modelleert de effecten van socio-economische eigenschappen, kenmerken van de reis- en woonlocatie op de woonlocatiekeuze, waarbij er een latent-variabele model is gebruikt om de tevredenheid met de huidige wijk en huis mee te nemen.

De resultaten laten zien dat individuen met een inkomen van meer dan drie keer het minimuminkomen bereid zijn meer grondbelasting te betalen om daarmee binnen een straal van 5 kilometer van de tolweg te wonen, zodat ze meer van de tolweg kunnen profiteren. Individuen uit andere inkomensklassen prefereren een woonlocatie op meer dan $10 \mathrm{~km}$ van de tolpoorten, waar de woonkosten in het algemeen lager zijn. Respondenten die op meer dan $10 \mathrm{~km}$ van de tolpoorten wonen zijn echter ontevredener met hun woonomgeving.

Door het keuzemodel uit te breiden met de tevredenheid met de huidige woonlocatie en wijk neemt de kans toe dat mensen in hun huidige woning willen blijven wonen, uitgezonderd individuen met een inkomen lager dan het minimuminkomen. Respondenten zijn tevreden met hun huidige wijk zolang ze in de buurt van de tolpoorten wonen. Personen zijn minder tevreden met de grootte en de betaalbaarheid van hun huis als ze dichter bij de tolpoort wonen, waarschijnlijk door de hogere huur of grondbelasting. Daarnaast blijkt dat respondenten met 
een laag inkomen vaak niet tevreden zijn met hun huidige woning en wijk en een verhuizing prefereren. Dit resultaat wordt versterkt door de bevinding dat dezelfde ontevredenheid wordt ondervonden door de respondenten die in de armere gemeenten wonen.

Hoofdstuk 5 verkent de effecten van de Cipularang tolweg op routekeuze en vervoerwijzekeuze en de interactie tussen route- en vervoerwijzekeuze en woonlocatiekeuze. Deze studie draagt bij aan de literatuur door het reisgedrag te bekijken van verschillende bevolkingsgroepen als reactie op de aanleg van een tolweg. Hierbij wordt er gebruik gemaakt van (1) een samengesteld model met woonlocatiekeuze en route- en vervoerwijzekeuze om te onderzoeken of zelfselectie effecten optreden en (2) een hybride keuzemodel om de houding ten opzichte van de tolweg en de vervoerwijze te bepalen. In Indonesië zijn talrijke nieuwe tolwegen in gebruik genomen in het afgelopen decennium. Toch is er geen studie die het reisgedrag van verschillende bevolkingsgroepen en de relatie met woonlocatiekeuze uitvoerig bestudeert.

In dit onderzoek is er gebruik gemaakt van de data van een samengesteld stated choice experiment voor woonlocatiekeuze en reisgedrag (route- en vervoerwijzekeuze). Respondenten werden gevraagd om te kiezen tussen vier alternatieven, die elk bestonden uit een combinatie van een route en een vervoerwijze: (1) reizen via de tolweg met hun gebruikelijke modaliteit, (2) reizen via de tolweg middels een andere modaliteit, (3) reizen met hun gebruikelijke modaliteit via een route zonder de tolweg, of (4) reizen met een andere modaliteit via een route zonder de tolweg. Elke keuzekaart had verschillende waarden voor de reiskosten en -tijd, die gebaseerd zijn op de werkelijke waarden van de meest recente reis van de respondent via de tolweg. Opt-out opties, zoals "ik prefereer een andere modaliteit" (bijvoorbeeld motor(fiets) of trein) en "ik prefereer niet te reizen", werden ook aangeboden.

De resultaten laten zien dat, in het algemeen, respondenten een voorkeur hebben voor opties die gebruik maken van de Cipularang tolweg. Dit geldt niet voor respondenten met een laag inkomen, zij selecteerden bij voorkeur de opt-out optie (gebruik van een andere vervoerwijze zoals motor(fiets) of trein), in tegenstelling tot respondenten met relatief hoge inkomens die een voorkeur hebben voor opties die gebruik maken van de tolweg. De respondenten waarderen reiskosten en reistijd negatief, waarbij autogebruikers met een laag inkomen het meest gevoelig zijn voor een toename in reiskosten. Het model laat zien dat andere variabelen, zoals leeftijd, geslacht, reismotief en -frequentie, een significante invloed hebben op de routekeuze en vervoerwijze.

Verder laten de modelresultaten zien dat route-, vervoerwijze- en woonlocatiekeuzen samenhangen. Het is aannemelijk dat respondenten niet willen verhuizen als ze dichtbij de tolpoorten wonen en graag gebruik te maken van de tolweg. Frequente gebruikers van de tolweg kiezen niet voor de opties waarbij geen gebruik gemaakt wordt van de tolweg, en zijn geneigd om te verhuizen. Respondenten met een laag inkomen zijn ook geneigd om te verhuizen. Dit impliceert dat ze ontevreden zijn over hun huidige situatie, wat ook wordt weergegeven door de negatieve attitude ten opzichte van hun huidige modaliteit. Dit verband laat een interactie zien tussen route- en modaliteitskeuze enerzijds en woonlocatiekeuze anderzijds.

Samenvattend geeft dit proefschrift empirisch bewijs dat een tolweg zowel directe als indirecte effecten kan hebben, en dat deze effecten ongelijkmatig verdeeld kunnen zijn over regio's en individuen. Dit proefschrift laat ook zien dat de aanleg van tolweg in ontwikkelingslanden zowel positieve als negatieve effecten kan hebben. De context speelt hierbij een rol. Het onderzoek is uitgevoerd in een regio waar (1) activiteiten onevenwichtige verdeeld zijn, (2) het transportsysteem niet volledig ontwikkeld is en (3) een grote ongelijkheid van inkomen bestaat. 
Dit proefschrift draagt bij aan de ontwikkeling van het wetenschappelijke kennis over effecten van investeringen in nieuwe weginfrastructuur door diepgaande analyses van de effecten op zowel regionaal- als individueel niveau. Deze analyse combineert GIS-analyse en gedragsmodellen op individueel niveau, door gebruik te maken van grootschalig stated en revealed choice experimenten.

De resultaten van dit proefschrift benadrukken het belang van bereikbaarheids- en ongelijkheidsanalyses in de beleidspraktijk. Bereikbaarheidsplanning integreert landgebruik en transport planning om daarmee alle individuen in staat te stellen, ongeacht hun sociale klasse, deel te laten nemen aan activiteiten in een gebied. Dit proefschrift benadrukt ook de relevantie van de beleidscyclus. Een ex-post beleidsevaluatie is essentieel om te beoordelen of de initiële doelen zijn behaald, maar ook om indirecte effecten te identificeren. Een ex-post evaluatie is noodzakelijk of om steun te vinden voor de initiële beweegredenen of om de noodzaak voor het aanpassen van het transportbeleid te bepalen.

Het proefschrift doet verschillende aanbevelingen voor vervolgonderzoek. Onder andere wordt er aanbevolen om analyse van de bereikbaarheid van banen te verbeteren door data te verzamelen over het opleidingsniveaus van werkenden, verschillende type banen en banen in de informele sector. Daarnaast is het belangrijk om ook te kijken naar de locatiekeuzen van bedrijven en hun werknemers in de analyse van bereikbaarheid van werk, en om de veranderingen in het industriële landgebruik te verklaren als het gevolg van de aanleg van de tolweg. Vervolgonderzoek wordt ook aanbevolen voor de effecten van de Cipularang tolweg op ritten met een vrijetijds- en ontspanningsmotief, aangezien deze reismotieven veel voorkomen onder gebruikers van deze tolweg. 


\section{Ringkasan dalam Bahasa Indonesia}

Beberapa alasan mendasari dilakukannya pembangunan jalan tol. Di sejumlah negara berkembang, seperti Malaysia, Thailand dan Indonesia, jalan tol biasanya dibangun pada trase yang merupakan jalan arteri atau koridor utama sebagai bagian dari skenario untuk pengembalian dana investasi pembangunan jalan tersebut. Sementara di negara maju dan wilayah metropolitan, seperti London (Inggris) dan Stockholm (Swedia), tol diterapkan untuk mempengaruhi perilaku pengguna jalan sehingga dapat mengurangi kemacetan. Terlepas dari dari tujuan pembangunannya, pembangunan jalan tol dapat berdampak secara langsung maupun tidak langsung bagi pembangunan wilayah maupun masyarakat luas.

Dampak langsung dari pembangunan jalan baru berkaitan dengan, misalnya, perubahan waktu tempuh, jarak tempuh, dan biaya perjalanan. Pada akhirnya, hal ini akan mengubah perilaku perjalanan seseorang, misalnya dengan mengubah rute atau moda perjalanannya. Seiring dengan berjalannya waktu, pengguna jalan dapat pula tertarik untuk berpindah lokasi tempat tinggal. Hal ini didefinisikan sebagai dampak tidak langsung dari pembangunan jalan baru. Manfaat atau dampak yang dirasakan dapat terdistribusi secara tidak merata, baik antar individu maupun antar wilayah. Sehubungan dengan hal tersebut, disertasi ini berfokus pada dampak langsung dan tidak langsung dari dampak pembangunan jalan tol terhadap individu perorangan maupun antar wilayah.

Di Indonesia, pada periode 2015-2018, hampir $600 \mathrm{~km}$ jalan tol baru mulai dioperasikan. Hal ini disebabkan oleh Pemerintah yang mendorong pembangunan jalan tol untuk meningkatkan konektivitas regional. Namun, paradigma 'prediksi dan menyediakan (predict and provide),' yakni pembangunan infrastruktur transportasi yang hanya untuk memenuhi permintaan (hanya untuk mengatasi masalah jangka pendek, seperti kemacetan), tanpa mempertimbangkan dampak jangka panjang baik langsung maupun tidak langsung, masih banyak digunakan. Idealnya, kebijakan transportasi harus mengikuti siklus pengambilan keputusan, dimana kebutuhan atau alasan pembangunannya harus diidentifikasi terlebih dahulu, untuk kemudian dapat menentukan tujuan sistem transportasi atau tingkat layanan sistem yang diinginkan. Kemudian, evaluasi pada tahap perencanaan (ex-ante) dilakukan untuk mengidentifikasi alternatif kebijakan atau proyek transportasi yang akan diimplementasikan. Langkah-langkah selanjutnya (pemantauan, evaluasi pasca pelaksanaan dan umpan balik) setelah kebijakan telah 
diterapkan justru sering diabaikan. Evaluasi pasca pelaksanaan (ex-post) sangat penting untuk menilai hasil yang dicapai, dan untuk mengidentifikasi dampak tidak langsung yang muncul dari proyek pembangunan infrastruktur tersebut.

Selain itu, dalam praktiknya, penilaian ekuitas (equity appraisals) hanya mendapat sedikit perhatian dalam evaluasi pembangunan infrastruktur transportasi di negara berkembang, seperti Indonesia. Penilaian proyek pembangunan infrastruktur transportasi saat ini sebagian besar didasari oleh evaluasi ekonomi (misalnya dengan analisis biaya dan manfaat), dimana tidak ada perhatian lebih jauh mengenai bagaimana manfaat pembangunan infrastruktur transportasi tersebut terdistribusi antar individu, baik pengguna maupun bukan pengguna layanan infrastruktur transportasi tersebut.

Berdasarkan penjelasan di atas, makan tujuan utama dari penelitian dalam disertasi ini adalah:

Untuk memberikan pemahaman komprehensif mengenai dampak langsung dan tidak langsung dari pembangunan jalan tol di wilayah Jakarta - Bandung di Indonesia, dan bagaimana perbedaan dampak yang ditimbulkan tersebut antar wilayah geografis dan antar kelompok masyarakat.

Wilayah Jakarta - Bandung di Indonesia dipilih sebagai lokasi penelitian ini. Dua kota metropolitan tersebut terhubung oleh jalan tol Cipularang, yang kemudian membentuk kawasan perkotaan dengan jumlah populasi terbesar di Indonesia. Wilayah ini memiliki posisi yang penting pada skala nasional. Dengan luas kurang dari 1\% dari total luas wilayah Indonesia, $30 \%$ dari total panjang jalan tol nasional terletak di wilayah ini dan $14 \%$ dari total populasi Indonesia bertempat tinggal di wilayah tersebut.

Analisis dalam disertasi ini dilakukan pada tingkat regional dan individu untuk mengidentifikasi bagaimana pembangunan jalan tol Cipularang berpengaruh pada sistem transportasi dan bagaimana manfaat pembangunannya terdistribusi antar wilayah dan antar kelompok masyarakat. Analisis dampak regional dilakukan dengan analisis spasial dan pemodelan Sistem Informasi Geografis (SIG). Sementara itu, analisis dampak terhadap individu dilakukan dengan menggunakan data stated dan revealed preference terhadap pemilihan lokasi tempat tinggal, rute dan moda perjalanan. Data yang dihimpun bersumber dari survei terhadap 1.600 responden yang bertempat tinggal di sekitar jalan tol Cipularang.

Disertasi ini dibagi menjadi empat bagian. Dua bagian pertama berfokus pada dampak jalan tol di tingkat regional, yang kemudian dilanjutkan dengan dampak jalan tol terhadap individu perorangan. Bab 2 menjabarkan hasil analisis dari dampak dari jalan tol terhadap proyek pembangunan jalan lokal di wilayah Jakarta-Bandung. Literatur terkait pada dampak pembangunan jalan sebagai stimulan investasi jalan lain sejauh ini hanya ditemukan di negaranegara maju, seperti Amerika Serikat atau negara-negara Eropa. Diperlukan pemahaman yang lebih mendalam tentang bagaimana proyek pembangunan infrastruktur jalan tol dapat mendorong investasiuntuk pembangunan jalan lokal sehingga memberikan manfaat untuk peningkatan aksesibilitas regional. Hal ini sangat relevan di negara-negara berkembang dengan sistem pemerintahan terdesentralisasi seperti Indonesia, dimana terdapat beberapat tingkat pemerintahan yang berbagi tanggung jawab untuk untuk pembangunan dan pengelolaan infrastruktur transportasi. Pemerintah pusat Indonesia memiliki otorisasi untuk pembangunan jalan nasional, seperti jalan tol. Pemerintah tingkat provinsi memiliki kewenangan terhadap pembangunan jalan berskala provinsi. Sementara pemerintah pada tingkat lebih rendah memiliki kewenangan pada ruas jalan di tingkat lainnya, seperti kabupaten/kota yang mengendalikan proyek pembangunan jalan lokal. Dengan demikian, koordinasi antar tingkat 
pemerintahan maupun antar pemerintah daerah, bagaimanapun, menjadi sangat vital untuk dapat meningkatkan manfaat investasi transportasi lintas/antar wilayah.

Sejauh pengetahuan penulis, belum ada penelitian yang pernah menyelidiki hubungan antara investasi jalan nasional dan pengambilan keputusan untuk proyek jalan lokal. Maka untuk menyelidiki investasi pada jalan lokal tersebut, dalam penelitian ini dikembangkan empat model: (1) model pengambilan keputusan, (2) model dampak langsung, (3) model dampak tidak langsung, dan (4) model komposit, yang menggabungkan ketiga model sebelumnya.

Hasil pemodelan menunjukkan bahwa jalan tol yang sudah terbangun dan beroperasi maupun yang sedang direncanakan mendorong pengembangan proyek jalan lokal baik secara langsung maupun tidak langsung. Proyek jalan lokal cenderung dilakukan untuk mengantisipasi pembukaan jalan tol, dan digadang-gadang oleh pemerintah daerah untuk mengurangi waktu tempuh perjalanan. Alih fungsi lahan menjadi lahan permukiman dan peningkatan jumlah penduduk di sekitar jalan tol juga mendorong dilakukannya pembangunan jalan lokal. Akan tetapi, variabel-variabel ini ditemukan kurang sensitif dibandingkan variabel lain dalam penelitian ini, seperti jarak ke gerbang tol, waktu (dalam tahun) antara pembangunan jalan tol dan pembangunan jalan lokal, dan biaya pembangunan yang diperlukan. Temuan-temuan ini memperkuat argumen bahwa tidak hanya dampak permintaan (demand effects), namun juga dampak pasokan (supply effects) yang perlu diperhitungkan dalam penilaian proyek pembangunan jalan.

Bab 3 memaparkan bagaimana dampak aksesibilitas jalan tol terdistribusi antar wilayah yang berdekatan. Hal ini dilakukan dengan menghitung aksesibilitas terhadap pekerjaan (job accessibility) dan ekuitas spasial (spatial equity) dalam skenario dengan dan tanpa jalan tol. Evaluasi pasca pelaksanaan (ex-post) dampak jalan tol terhadap aksesibilitas pekerjaan dan ekuitas spasial dalam konteks negara berkembang, sepengetahuan penulis, belum pernah dilakukan sebelumnya. Pada penelitian ini, model simulasi lalu lintas makroskopik, dengan menggunakan Traffic Analyst yang merupakan ekstensi ArcGIS, digunakan untuk mendapatkan perkiraan waktu tempuh dan biaya perjalanan secara umum (generalized travel cost), dengan mempertimbangkan dampak kemacetan dan nilai waktu (berdasarkan hasil survei rumah tangga, lebih lanjut dibahas pada Bab 4 dan 5).

Terdapat sejumlah metode untuk mengukur aksesibilitas. Dalam studi ini, dua indikator aksesibilitas digunakan, yakni aksesibilitas potensial dan Indeks Shen. Aksesibilitas potensial menggunakan fungsi peluruhan jarak log-logistik, dimana diasumsikan bahwa semakin jauh jarak antara lokasi pekerjaan dan tempat tinggal penduduk tersebut, maka semakin kecil kemungkinan untuk bepergian. Indeks Shen menyempurnakan perhitungan aksesibilitas potensial dengan mengukur dampak persaingan. Indeks Shen menghitung proporsi jumlah pekerjaan yang dapat dicapai (potensi persediaan pekerjaan) dengan jumlah penduduk yang dapat mencapainya (potensi permintaan) dengan mempertimbangkan jarak tempuh perjalanan disertai dengan fungsi peluruhan yang sama.

Selain itu, dampak terhadap ekuitas dinilai dengan menggunakan rasio Palma dan koefisien Gini, serta distribusi spasial dari perubahan aksesibilitas menggunakan analisis klaster dua langkah. Koefisien Gini dihitung dengan menggunakan pendekatan kurva Lorenz, yang menggambarkan (peringkat) proporsi kumulatif dari aksesibilitas per orang terhadap proporsi kumulatif dari populasi yang ada, berdasarkan kecamatan, di seluruh wilayah Jakarta Bandung. Rasio Palma adalah rasio antara aksesibilitas rata-rata 10\% kecamatan terkaya dan $40 \%$ kecamatan termiskin, berdasarkan data pengeluaran per kapita. Nilai aksesibilitas tersebut kemudian dikelompokkan berdasarkan karakteristik pertumbuhan guna lahan permukiman, 
jumlah pekerjaan, jumlah penduduk usia kerja dan pengeluaran per kapita per bulan. Pengelompokkan dilakukan dengan menggunakan metode klaster dua langkah di mana jumlah klaster ditentukan berdasarkan nilai minimum kriteria informasi Bayesian.

Hasil analisis menunjukkan bahwa pembangunan jalan tol Cipularang mengurangi waktu tempuh rata-rata di wilayah Jakarta-Bandung sebesar $13 \%$. Untuk kecamatan tertentu yang terletak di ujung utara dan selatan jalan tol, waktu tempuh bahkan berkurang 1,5 kali lipat. Pengurangan waktu tempuh perjalanan juga mempengaruhi aksesibilitas pekerjaan. Aksesibilitas pekerjaan dan populasi usia kerja masing-masing meningkat sebesar 5\% dengan dibangunnya jalan tol. Namun demikian, hasil penelitian ini juga menunjukkan bahwa jalan tol juga meningkatkan persaingan pekerjaan karena lebih banyak pekerja yang sekarang dapat mengakses pekerjaan yang tersedia di daerah miskin-pekerjaan antara Jakarta dan Bandung, seperti Purwakarta, sehingga terjadi sedikit penurunan dalam jumlah pekerjaan yang dapat diakses per pekerja. Dengan kata lain, adanya jalan tol ini juga meningkatkan kompetisi untuk mendapatkan pekerjaan.

Lebih lanjut ditemukan bahwa tidak ada dampak ketidaksetaraan spasial (spatial inequity) dari pembangunan jalan tol. Hal ini dikarenakan tidak diikutsertakannya analisis pemilihan moda dalam studi ini. Pada praktiknya, pekerja berpendapatan menengah ke bawah lebih memilih untuk menggunakan sepeda motor pribadi, yang tidak dapat digunakan melalui jalan tol. Dengan demikian, pekerja berpendapatan tinggi lebih sering menggunakan jalan tol dan lebih mendapatkan manfaat langsungnya.

Bab-bab selanjutnya berfokus pada dampak jalan tol pada tingkat individu perorangan, yang dilakukan dengan menggunakan data survei rumah tangga. Survei dilakukan dengan menggunakan teknologi computer-aided personal interview (CAPI). Responden tepilih merupakan responden yang bertempat tinggal di daerah yang mengalami perubahan penggunaan lahan yang besar selama kurun waktu 2004-2013, yang meliputi 35 desa (kelurahan). Sepuluh kelurahan yang terletak antara 6 dan $12 \mathrm{~km}$ dari jalan tol juga dimasukkan dalam sampel sebagai area kontrol. Responden diambil berdasarkan metode pengambilan sampel acak terstratifikasi (stratified random sampling). Pengelompokan didasarkan pada proporsi jenis kelamin dan kelompok umur dalam populasi.

Bab 4 memberikan pembahasan empiris mengenai pemilihan lokasi tempat tinggal sebagai respon atas keberadaan jalan tol. Tidak terdapat banyak studi kuantitatif yang meneliti dampak infrastruktur jalan terhadap pemilihan lokasi tempat tinggal di negara-negara berkembang. Sepengetahuan penulis, belum ada penelitian yang membahas jalan tol terkait hal ini. Hal ini tentu menjadi sangat menarik mengingat dalam penggunaan jalan tol terdapat hubungan timbal balik antara penghematan waktu tempuh perjalanan dan penambahan komponen biaya tol.

Bab ini menyajikan evaluasi pasca pelaksanaan (ex-post) yang komprehensif terhadap pembangunan jalan tol dalam konteks negara-negara berkembang, menggunakan data survei stated dan revealed preference. Data dianalisis melalui penerapan model logit campuran (mixed logit) dan model pilihan hibrida (hybrid choice model) untuk menganalisis pengaruh komponen kepuasan (faktor laten) dalam pemilihan lokasi tempat tinggal terkait dengan pembangunan jalan tol, menggunakan beberapa segmen jarak ke gerbang tol.

Analisis dalam bab ini menggunakan data dari percobaan pilihan (stated choice) untuk pemilihan lokasi tempat tinggal, di mana responden diberikan beberapa kartu pilihan. Untuk setiap kartu pilihan, mereka harus memilih antara rumah hipotesis A, rumah hipotesis B dan rumah mereka saat ini. Setiap opsi memiliki nilai atribut yang berbeda (dari segi pajak nilai lahan / biaya sewa, waktu tempuh perjalanan untuk bekerja, biaya perjalanan untuk bekerja dan 
jarak ke gerbang tol). Nilai atribut divariasikan dari data responden saat ini, sehingga menyerupai kondisi aktual responden. Untuk menganalisis data tersebut, model pilihan hibrida dikembangkan untuk memodelkan dampak sosial ekonomi, karakteristik perjalanan, karakteristik perumahan dan juga dampak faktor laten, seperti kepuasan terhadap kondisi lingkungan tempat tinggal dan rumah saat ini terhadap pemilihan lokasi perumahan.

Hasil analisis menunjukkan bahwa responden yang pendapatannya setidaknya tiga kali dari upah minimum (responden berpendatan tinggi) bersedia membayar pajak nilai lahan / biaya sewa yang lebih tinggi untuk tinggal lebih dekat dari $5 \mathrm{~km}$ ke gerbang tol sehingga dapat memperoleh manfaat penurunan waktu perjalanan. Sementara responden lainnya lebih suka bertempat tinggal di lokasi lebih jauh dari $10 \mathrm{~km}$ dari gerbang tol di mana harga rumah cenderung lebih rendah. Akan tetapi, hal tersebut mengarah pada ketidakpuasan terhadap aspek lingkungan (sebagai fungsi dari aksesibilitas) bagi responden yang tinggal $10 \mathrm{~km}$ lebih jauh dari gerbang tol.

Selain itu, penambahan komponen kepuasan dengan kondisi rumah dan lingkungan tempat tinggal saat ini ke dalam model dapat meningkatkan probabilitas responden untuk tetap tinggal di huniannya saat ini. Terkecuali untuk responden yang pendapatannya lebih rendah dari upah minimum (responden berpendapatan rendah). Responden golongan ini merasa puas dengan lingkungan tempat tinggal mereka jika mereka bertempat tinggal dekat dengan gerbang tol. Namun, jika responden tersebut bertempat tinggal lebih dekat dengan gerbang tol, mereka cenderung merasa tidak puas dengan ukuran dan keterjangkauan harga hunian mereka, mungkin karena harga sewa atau pajak lahan yang lebih tinggi. Selain itu, responden berpenghasilan rendah merasa tidak puas dengan kondisi hunian dan lingkungan tempat tinggal mereka saat ini, dan memilih untuk berpindah hunian. Hasil ini diperkuat dengan temuan bahwa ketidakpuasan yang sama juga dialami oleh responden yang tinggal di kabupaten yang tergolong miskin.

Bab 5 mengeksplorasi dampak jalan tol pada perilaku perjalanan individu dan interaksi antara perilaku perjalanan dan pemilihan lokasi tempat tinggal. Studi ini memperkaya literatur dengan mengidentifikasi dampak perilaku perjalanan di berbagai segmen populasi dalam menanggapi kehadiran jalan tol dengan menggunakan (1) model gabungan (joint model) pemilihan lokasi tempat tinggal dan pemilihan rute dan moda perjalanan, untuk mengidentifikasi pemilihan berdasarkan preferensi pribadi (self-selection), dan (2) model pilihan hibrida, untuk mengidentifikasi pengaruh dari sikap responden (attitude) terkait jalan tol dan moda perjalanan. Dalam konteks Indonesia, di mana banyak jalan tol baru dioperasikan dalam dekade terakhir, tidak ada penelitian yang menyelidiki dampak perilaku perjalanan antar individu perorangan dan hubungannya dengan keputusan lokasi tempat tinggal secara lebih rinci. Secara umum, hal ini kemudian menjadi sangat penting, mengingat dampak jalan tol yang bervariasi bergantung pada karakteristik perjalanan dan juga kondisi sosial ekonomi penggunanya.

Analisis dilakukan dengan menggunakan data dari percobaan pilihan (stated choice) untuk pemilihan lokasi tempat tinggal dan perilaku perjalanan (pilihan rute dan moda perjalanan). Para responden diminta untuk memilih satu di antara empat alternatif, yang merupakan kombinasi dari pilihan rute dan moda, yaitu (1) bepergian melalui jalan tol dan menggunakan moda yang sama, (2) bepergian melalui jalan tol dan menggunakan moda yang berbeda, (3) menggunakan moda yang sama tetapi tidak bepergian melalui jalan tol, atau (4) tidak bepergian melalui jalan tol dan menggunakan moda yang berbeda. Setiap kartu pilihan berisi nilai berbeda untuk atribut biaya perjalanan dan waktu perjalanan, yang divariasikan dari biaya dan waktu perjalanan terakhir responden melalui jalan tol. Pilihan lain (opt-out), seperti "lebih suka moda yang berbeda" (mis. sepeda motor atau kereta api) dan "lebih suka tidak bepergian", juga 
disediakan. Dua opsi terakhir ini disediakan agar tidak terjadi pemaksaan dalam memilih, apabila responden merasa tidak ada pilihan yang sesuai dengan preferensinya.

Hasil estimasi model menunjukkan bahwa, secara umum, responden lebih menyukai opsi yang memanfaatkan jalan tol. Namun, responden berpenghasilan rendah akan memilih opsi lain, yang memungkinkan mereka melakukan perjalanan menggunakan moda perjalanan termurah (seperti kereta atau sepeda motor), berbeda halnya dengan responden berpenghasilan tinggi yang lebih suka menggunakan jalan tol. Pengemudi mobil yang berpenghasilan rendah merupakan segmen populasi yang paling sensitif terhadap kenaikan biaya perjalanan. Variabel lain, seperti usia, jenis kelamin, tujuan perjalanan, dan frekuensi perjalanan, juga ditemukan memiliki pengaruh yang signifikan terhadap pemilihan rute dan moda perjalanan.

Selain itu, pemilihan rute, moda, dan lokasi tempat tinggal juga ditemukan saling terkait melalui parameter jarak ke gerbang tol, frekuensi perjalanan, dan tingkat pendapatan yang berada di kedua model tersebut. Responden yang tinggal di dekat gerbang tol lebih suka menggunakan jalan tol dan memilih tinggal di tempat tinggal mereka saat ini. Sementara responden yang kerap bepergian melalui jalan tol tidak akan memilih opsi tanpa jalan tol dan memiliki kecenderungan untuk pindah dari lokasi huniannya saat ini.

Responden berpenghasilan rendah juga cenderung memilih pindah dari perumahan mereka saat ini. Hal ini menyiratkan ketidakpuasan terhadap situasi mereka saat ini, seperti juga ditunjukkan oleh sikap negatif mereka terhadap moda perjalanan mereka saat ini, dan lebih memilih situasi lain. Keterkaitan ini menunjukkan interaksi antara pemilihan rute dan moda perjalanan dan keputusan lokasi tempat tinggal.

Simpulannya, disertasi ini memberikan bukti empiris bahwa jalan tol dapat memiliki dampak langsung dan tidak langsung, dan bahwa dampak ini dapat terdistribusi secara tidak merata antar wilayah geografis maupun antar kelompok masyarakat. Disertasi ini juga menunjukkan bahwa pembangunan jalan tol baru dapat memiliki dampak positif dan negatif, terutama di daerah dengan distribusi kegiatan yang tidak seimbang, sistem transportasi yang belum dikembangkan dengan baik, dan disparitas pendapatan antar individu yang tinggi.

Kemudian, disertasi ini memberikan kontribusi terhadap evaluasi pembangunan infrastruktur transportasi, melalui analisis komprehensif di tingkat regional dan individu dalam mengevaluasi dampak jalan tol. Hal ini dilakukan dengan menggabungkan analisis analisis spasial dan pemodelan sistem infromasi geografis serta pemodelan perilaku individu menggunakan data stated dan revealed preference.

Temuan penelitian ini mendesak penggabungan perencanaan aksesibilitas ke dalam praktik kebijakan. Perencanaan aksesibilitas menggarisbawahi integrasi penggunaan lahan dan perencanaan transportasi dengan tujuan memungkinkan semua individu, terlepas dari kelas sosial atau kemampuan mereka, untuk berpartisipasi dalam setiap kegiatan di daerah tersebut dengan menggunakan sistem transportasi yang tersedia. Disertasi ini juga menekankan pentingnya siklus kebijakan transportasi, dan bahwa evaluasi pasca pelaksanaan (ex-post) sangat penting dalam menilai apakah tujuan suatu pembangunan infrastruktur tercapai, serta untuk mengidentifikasi dampak tidak langsung yang timbul dari pembangunan infrastruktur tersebut. Evaluasi pasca pelaksanaan diperlukan sebagai argumen untuk menginisiasi kebijakan transportasi lainnya.

Agenda penelitian kedepan dapat diarahkan pada banyak hal. Diantaranya, memperbaiki dan memperkaya analisis aksesibilitas terhadap pekerjaan melalui pengumpulan dan analisis data sektor pekerjaan, termasuk sektor informal, serta latar pendidikan responden. Selain itu, penting 
pula untuk menganalisis proses relokasi perusahaan/industri dan pekerja mereka dalam penilaian aksesibilitas pekerjaan. Hal ini juga dapat dilakukan untuk mengembangkan model perubahan guna lahan industri terkait dengan pembangunan jalan tol. Penelitian lebih lanjut juga dapat mempelajari dampak dari jalan tol untuk perjalanan wisata, mengingat jenis perjalanan ini juga sangat penting bagi pengguna jalan tol ini. 
this page is intentionally left blank 


\section{About the Author}

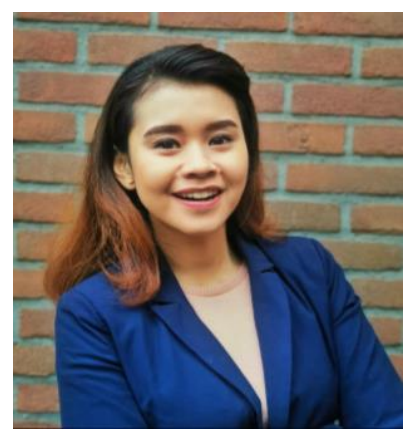

IG Ayu Andani was born in Denpasar, Indonesia on December $21^{\text {st }}, 1990$. She obtained both her bachelor and master degrees, with cum laude, from Urban and Regional Planning Department, Institut Teknologi Bandung (ITB), focused on infrastructure and transportation planning.

After her graduation, she has worked as a lecturer in her hometown university and did several spatial planning projects. In the early 2015, she was appointed as a lecturer in her alma-mater university, Institut Teknologi Bandung. In June 2015, she started working as a Ph.D student in the Centre of Transport Studies, University of Twente, the Netherlands, funded by The Royal Netherlands Academy of Arts and Sciences (KNAW) as a part of the research programme 'The local and regional dimensions in Indonesia's social and economic development'.

In her free time, she enjoys travelling across Europe, watching movies, or just being outdoors and spending time with her friends. She will return to her position in Institut Teknologi Bandung (ITB), Indonesia, after finishing her PhD. 


\section{Author's publication}

\section{Journal Publications}

Andani, I.G.A., La Paix Puello, L., Geurs, K. (2019). Effects of toll road construction on local road projects in Indonesia. Journal of Transport and Land Use, 12(1), 179-199. http://dx.doi.org/10.5198/jtlu.2019.1258

Andani, I.G.A., La Paix Puello, L., Rachmat, S., Syabri, I., Geurs, K (2019). An ex-post evaluation of the job accessibility and spatial equity impacts of a toll road in the Jakarta Bandung region, Indonesia. Submitted to Journal of Transport Geography (under review).

Andani, I.G.A., La Paix Puello, L., Geurs, K. (2019). Exploring the role of toll road construction on residential location choice in Jakarta - Bandung Region. Submitted to Journal of Case Studies on Transport Policy (under review).

Andani, I.G.A., La Paix Puello, L., Geurs, K (2019). Modelling effects of changes in travel time and costs of toll road usage on choices for residential location, route and travel mode across population segments in the Jakarta-Bandung region, Indonesia. Submitted to Journal of Transportation Research Part A: Policy and Practice (under review).

\section{Conference proceeding (peer reviewed)}

Andani, I.G.A., Syabri, I., Rachmat, S., Geurs, K. (2015). The impact of decentralization on road infrastructure investment In Jakarta-Bandung region, Indonesia. Proceeding of the 3rd Planocosmo International Conference, October 26 -27, 2015, Bandung, Indonesia.

\section{Presentations (non-peer reviewed)}

Andani, I.G.A. (2018). Effects of a toll road construction on the travel behavior of transportdisadvantaged group: a case study in Indonesia. Presented at TRAIL Congress, November $15^{\text {th }}$, 2018, Utrecht, the Netherlands.

Andani, I.G.A., La Paix Puello, L., Geurs, K. (2018). The influence of toll road construction on residential location decision: a case study in Indonesia. Presented at the $7^{\text {th }}$ Symposium of the European Association for Research in Transportation (hEART 2018), September 5-7, 2018, Athens, Greece.

Andani, I.G.A., La Paix Puello, L., Geurs, K. (2018). Modelling urban growth in the Jakarta Bandung region: does accessibility matter. Presented at Network on European Communications and Transport Activities Research (NECTAR) Accessibility Workshop, June 18-19, 2018, Lyon, France.

Andani, I.G.A., La Paix Puello, L., Geurs, K. (2017). Assessing spatial equity impacts: ex-post evaluation of the Cipularang toll road construction. Presented at Network on European Communications and Transport Activities Research (NECTAR) Conference, May 31 - June 2, 2017, Madrid, Spain. 
Andani, I.G.A. (2016). Does decentralization matter? The effect of toll-road investment on the decision-making process of local transport infrastructure projects in Indonesia. Presented at TRAIL Congress, November $8^{\text {th }}, 2016$, Utrecht, the Netherlands.

Andani, I.G.A., Syabri, I., Rachmat, S., Geurs, K. (2015). The impact of decentralization on road infrastructure investment in Jakarta-Bandung region, Indonesia. Presented at the 3rd Planocosmo International Conference, October 26 -27, 2015, Bandung, Indonesia. 
this page is intentionally left blank 


\section{TRAIL Thesis Series}

The following list contains the most recent thesiss in the TRAIL Thesis Series. For a complete overview of more than 250 titles see the TRAIL website: www.rsTRAIL.nl.

The TRAIL Thesis Series is a series of the Netherlands TRAIL Research School on transport, infrastructure and logistics.

Andani, I.G.A., Toll Roads in Indonesia: transport system, accessibility, spatial and equity impacts, T2019/8, June 2019, TRAIL Thesis Series, the Netherlands

Ma, W., Sustainability of Deep Sea Mining Transport Plans, T2019/7, June 2019, TRAIL Thesis Series, the Netherlands

Alemi, A., Railway Wheel Defect Identification, T2019/6, January 2019, TRAIL Thesis Series, the Netherlands

Liao, F., Consumers, Business Models and Electric Vehicles, T2019/5, May 2019, TRAIL Thesis Series, the Netherlands

Tamminga, G., A Novel Design of the Transport Infrastructure for Traffic Simulation Models, T2019/4, March 2019, TRAIL Thesis Series, the Netherlands

Lin, X., Controlled Perishable Goods Logistics: Real-time coordination for fresher products, T2019/3, January 2019, TRAIL Thesis Series, the Netherlands

Dafnomilis, I., Green Bulk Terminals: A strategic level approach to solid biomass terminal design, T2019/2, January 2019, TRAIL Thesis Series, the Netherlands

Feng, Fan, Information Integration and Intelligent Control of Port Logistics System, T2019/1, January 2019, TRAIL Thesis Series, the Netherlands

Beinum, A.S. van, Turbulence in Traffic at Motorway Ramps and its Impact on Traffic Operations and Safety, T2018/12, December 2018, TRAIL Thesis Series, the Netherlands

Bellsolà Olba, X., Assessment of Capacity and Risk: A Framework for Vessel Traffic in Ports, T2018/11, December 2018, TRAIL Thesis Series, the Netherlands

Knapper, A.S., The Effects of using Mobile Phones and Navigation Systems during Driving, T2018/10, December 2018, TRAIL Thesis Series, the Netherlands

Varotto, S.F., Driver Behaviour during Control Transitions between Adaptive Cruise Control and Manual Driving: empirics and models, T2018/9, December 2018, TRAIL Thesis Series, the Netherlands

Stelling-Kończak, A., Cycling Safe and Sound, T2018/8, November 2018, TRAIL Thesis Series, the Netherlands 
Essen, van M.A., The Potential of Social Routing Advice, T2018/7, October 2018, TRAIL Thesis Series, the Netherlands

Su, Zhou, Maintenance Optimization for Railway Infrastructure Networks, T2018/6, September 2018, TRAIL Thesis Series, the Netherlands

Cai, J., Residual Ultimate Strength of Seamless Metallic Pipelines with Structural Damage, T2018/5, September 2018, TRAIL Thesis Series, the Netherlands

Ghaemi, N., Short-turning Trains during Full Blockages in Railway Disruption Management, T2018/4, July 2018, TRAIL Thesis Series, the Netherlands

Gun, van der J.P.T., Multimodal Transportation Simulation for Emergencies using the Link Transmission Model, T2018/3, May 2018, TRAIL Thesis Series, the Netherlands

Van Riessen, B., Optimal Transportation Plans and Portfolios for Synchromodal Container Networks, T2018/2, March 2018, TRAIL Thesis Series, the Netherlands

Saeedi, H., Network-Level Analysis of the Market and Performance of Intermodal Freight Transport, T2018/1, March 2018, TRAIL Thesis Series, the Netherlands

Ypsilantis, P., The Design, Planning and Execution of Sustainable Intermodal Port-hinterland Transport Networks, T2017/14, December 2017, TRAIL Thesis Series, the Netherlands

Han, Y, Fast Model Predictive Control Approaches for Road Traffic Control, T2017/13, December 2017, TRAIL Thesis Series, the Netherlands

Wang, P., Train Trajectory Optimization Methods for Energy-Efficient Railway Operations, T2017/12, December 2017, TRAIL Thesis Series, the Netherlands

Weg, G.S. van de, Efficient Algorithms for Network-wide Road Traffic Control, T2017/11, October 2017, TRAIL Thesis Series, the Netherlands

He, D., Energy Saving for Belt Conveyors by Speed Control, T2017/10, July 2017, TRAIL Thesis Series, the Netherlands

Bešinović, N., Integrated Capacity Assessment and Timetabling Models for Dense Railway Networks, T2017/9, July 2017, TRAIL Thesis Series, the Netherlands

Chen, G., Surface Wear Reduction of Bulk Solids Handling Equipment Using Bionic Design, T2017/8, June 2017, TRAIL Thesis Series, the Netherlands

Kurapati, S., Situation Awareness for Socio Technical Systems: A simulation gaming study in intermodal transport operations, T2017/7, June 2017, TRAIL Thesis Series, the Netherlands

Jamshidnejad, A., Efficient Predictive Model-Based and Fuzzy Control for Green Urban Mobility, T2017/6, June 2017, TRAIL Thesis Series, the Netherlands

Araghi, Y., Consumer Heterogeneity, Transport and the Environment, T2017/5, May 2017, TRAIL Thesis Series, the Netherlands 
Kasraian Moghaddam, D., Transport Networks, Land Use and Travel Behaviour: A long term investigation, T2017/4, May 2017, TRAIL Thesis Series, the Netherlands 


\section{Summary}

Toll roads can be implemented to influence users' travel behaviour and reduce congestion. In Indonesia, a toll is commonly implemented on major highways as a way to fund the construction. Regardless of their objective, toll roads can have a variety of effects. This thesis provides empirical evidence that a toll road can have direct and indirect effects and that these effects are distributed unevenly across geographic regions and individuals.

\section{About the Author}

IG Ayu Andani carried out her PhD research from 2015 to 2019 at the Centre for Transport Studies, University of Twente. Her research focus is the impacts of toll road construction on the transport system, accessibility, spatial and equity in Indonesia.

TRAIL Research School ISBN 978-90-5584-249-0

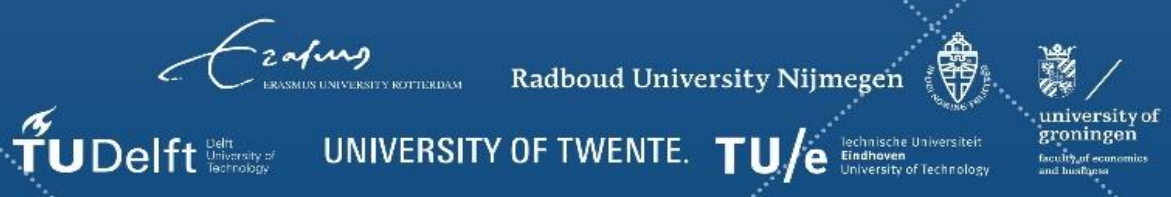

